Encounters between Jesuits and Protestants in Africa 


\title{
Jesuit Studies
}

MODERNITY THROUGH THE PRISM OF JESUIT HISTORY

VOLUME 13

\section{The Boston College International Symposia on Jesuit Studies}

\author{
Edited by \\ Robert Aleksander Maryks (Boston College)
}

Editorial Board

James Bernauer, S.J. (Boston College)

Louis Caruana, s.J. (Pontif icia Università Gregoriana, Rome)

Emanuele Colombo (DePaul University)

Paul Grendler (University of Toronto, emeritus)

Yasmin Haskell (University of Bristol)

Ronnie Po-chia Hsia (Pennsylvania State University)

Thomas M. McCoog, S.J. (Fordham University)

Mia Mochizuki (New York University Abu Dhabi and Institute of Fine Arts,

New York)

Sabina Pavone (Università degli Studi di Macerata)

Moshe Sluhovsky (The Hebrew University of Jerusalem)

Jeffrey Chipps Smith (The University of Texas at Austin)

VOLUME 2

The titles published in this series are listed at $\mathrm{brill.com} / \mathrm{js}$ 


\title{
Encounters between Jesuits and Protestants in Africa
}

\author{
Edited by \\ Robert Aleksander Maryks \\ Festo Mkenda, S.J.
}

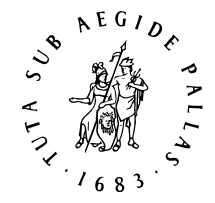

B R I L L

LEIDEN | BOSTON 
Cover illustration: A version of the IHS logo printed on the cover of early issues of the Zambesi Mission Record.

Library of Congress Cataloging-in-Publication Data

Names: Maryks, Robert A., editor.

Title: Encounters between Jesuits and Protestants in Africa / edited by

Robert Aleksander Maryks, Festo Mkenda, S.J.

Description: Leiden ; Boston : Brill, 2018. | Series: Jesuit Studies -

Modernity through the prism of Jesuit history, ISSN 2214-3289; VOLUME 13

| Includes index.

Identifiers: LCCN 2017049981 (print) | LCCN 2017051131 (ebook) | ISBN

9789004347151 (E-book) | ISBN 9789004347144 (hardback : alk. paper)

Subjects: LCSH: Africa--Church history. | Jesuits--Africa--History. |

Protestant churches--Africa--History. | Catholic

Church--Relations--Protestant churches. | Protestant

churches--Relations--Catholic Church.

Classification: LCC BR1360 (ebook) | LCC BR1360 .E525 2018 (print) | DDC

266.0096--dc23

LC record available at https://lccn.loc.gov/2017049981

Typeface for the Latin, Greek, and Cyrillic scripts: “Brill”. See and download: brill.com/brill-typeface.

ISSN 2214-3289

ISBN 978-90-04-34714-4 (hardback)

ISBN 978-90-04-34715-1 (e-book)

Copyright 2018 by the Editors and Authors.

This work is published by Koninklijke Brill NV. Koninklijke Brill NV incorporates the imprints Brill,

Brill Hes \& De Graaf, Brill Nijhoff, Brill Rodopi, Brill Sense and Hotei Publishing.

Koninklijke Brill NV reserves the right to protect the publication against unauthorized use and to authorize dissemination by means of offprints, legitimate photocopies, microform editions, reprints, translations, and secondary information sources, such as abstracting and indexing services including databases. Requests for commercial re-use, use of parts of the publication, and/or translations must be addressed to Koninklijke Brill NV.

This book is printed on acid-free paper and produced in a sustainable manner. 


\section{Contents}

\section{PART 1 \\ Introduction}

Protestantism and Early Jesuits 3

Robert Aleksander Maryks

Jesuits, Protestants, and Africa before the Twentieth Century 11 Festo Mkenda, s.J.

\section{PART 2}

Memories of Earlier Missions

1 Following in Jesuit Footsteps: British Expeditions to Ethiopia in the Early Victorian Era 33

Jesse Sargent

2 A Protestant Verdict on the Jesuit Missionary Approach in Africa: David Livingstone and Memories of the Early Jesuit Presence in South Central Africa 59

Festo Mkenda, s.J.

\section{PART 3}

Encounters in Southern Africa

3 Jesuits and Protestants in South Africa, 1685-2015 83 Anthony Egan, s.J.

4 Encounters between Jesuit and Protestant Missionaries in their Approaches to Evangelization in Zambia 110

Choobe Maambo, s.J.

5 Soror nostra es: Jesuits, Protestants, and Political Elites in Southern Africa among the Shona and the Ndebele, 1889-1900 132 Aquinata Agonga 
6 Jesuit Portraits of Protestant Missionary Activity in Southern Africa in the Nineteenth and Twentieth Centuries 150

Wilfred Sumani, s.J.

\section{PART 4}

Encounters in Madagascar, Congo, and Fernando Poo

7 Jesuits and Protestants in Nineteenth-century Madagascar 171 Jocelyn Rabeson, s.J.

8 Jesuit-Protestant Encounters in Colonial Congo in the Late Nineteenth Century: Perceptions, Prejudices, and the Competition for African Souls 194

Toussaint Kafarhire Murhula, s.J.

9 The Adulteresses Were Reformers: The Perception and Position of Women in the Religious Fight of Fernando Poo, 1843-1900 215 Jean Luc Enyegue, s.J.

Index 233 
PART 1

\section{Introduction}


Robert Aleksander Maryks and Festo Mkenda, S.J. - 978-90-04-34715-1 Downloaded from Brill.come4/26/2023 02:06:52PM via free access 


\title{
Protestantism and Early Jesuits
}

\author{
Robert Aleksander Maryks
}

The five-hundredth anniversary of the Protestant Reformation (1517) provides an opportunity to reflect in a new way on the relationship between the Protestants and the Society of Jesus, which was founded twenty-three years later (1540). Before we discuss the Jesuit-Protestant encounter in Africa, which resulted from the colonial expansion of the Catholic and Protestant European empires through the second half of the second millennium, let us begin by providing the broader historical context of the relationship of Ignatius of Loyola $(c .1491-1556)$ and the Society of Jesus, the order he co-founded, to Protestantism.

It is a commonplace in current scholarship and popular literature that the Jesuits were founded as a sort of papal troop to combat Protestantism. This anachronism, however, does not find support in the original Jesuit sourcesit had been invented, interestingly enough, by Ignatius's companions near and after his death, and the myth then became part of both Protestant and Jesuit historiographies, although they obviously employed different language to narrate the Society's origins and goals. The aim of this introductory essay is to show the contrast between the early Jesuit documents and later Jesuit and Protestant historiographies on the origins of the relationship between the Society of Jesus and Protestantism, with a special focus on Martin Luther (1483-1546), often called a "heresiarch" in the Jesuit sources.

As David Myers explained well in his essay on Ignatius and Luther for Brill's Companion to Ignatius of Loyola (2014),

Ignatius and Luther never met, and though Ignatius knew something of "Lutheranism," Luther never heard of the Jesuits' founder or of the Society of Jesus itself. Nor is it at all clear that Ignatius intended his Society to be a bulwark against the Protestant flood or that he was even a church reformer in the first place. The historical literature comparing the two men involves anachronism and stereotype rather than the details of their lives. Historians who talk of Ignatius and Luther have really been referring to Jesuits and Lutherans, as these groups crystallized in the half century following the deaths of their founders (Luther in 1546 and Ignatius in 1556). ${ }^{1}$

1 William David Myers, "Ignatius Loyola and Martin Luther: A History and Basis of a Comparison," in A Companion to Ignatius of Loyola: Life, Writings, Spirituality, and Influence, ed. Robert A. Maryks (Leiden: Brill, 2014), 141-58, here 141.

(C) ROBERT ALEKSANDER MARYKS, 2018 | DOI 10.1163/9789004347151_002

This is an open access chapter distributed under the terms of the prevailing CC-BY-NC-ND License. 978-90-04-34715-1 Downloaded from Brill.com04/26/2023 02:06:52PM 
Indeed, the earliest Jesuit sources describing Ignatius's life and the beginnings of the Society rarely mention Luther or other Reformed leaders and Protestantism more broadly. ${ }^{2}$ This is quite understandable for those documents narrating the life of Ignatius in 1520 Spain, where Protestantism had very limited impact and the Spanish ecclesiastical authorities, in particular the Inquisition, were more concerned about the spread of the alumbrado movement. ${ }^{3}$ It is striking, however, that the narratives of Ignatius's permanence at the University of Paris between 1527 (just after John Calvin's [1509-64] departure from there $)^{4}$ and 1535 -including those by his first companions like Pierre Favre (1506-46), Diego Laínez (1512-63), Simão Rodrigues (1510-79), or Nicolás Bobadilla (1511-90) - where disputes with Protestants, including the famous Affaire des placards (October 17, 1534), ${ }^{5}$ made much fuss, lack any significant references to Luther or Protestantism. ${ }^{6}$ To be sure, the eyes of the first companions were directed more to Jerusalem and its Muslim population as a target of their proselytization than to Wittenberg, where Luther's movement symbolically began.

What is even more striking, these references are missing in the foundational documents of the Society, such as the Formula Instituti (1539) and the Constitutions (promulgated in 1558), in which the first Jesuits defined the identity of their new religious order and its aim. True, the adjusted formula of 1550, five years before the Peace of Augsburg, ${ }^{7}$ defines the Society's additional goal as defense of the faith, but there is no explicit mention of Protestantism. Hence the Jesuits described therein cannot be defined as a Counter-Reformation force, even if part of the Jesuit efforts in the Holy Roman Empire, including those of Peter Canisius (1521-97), were indeed dedicated to countering the success of Protestantism.

2 See, for example, Jos E. Vercruysse, "'Melanchthon, qui modestior videri voluit [...]': Die ersten Jesuiten und Melanchthon," in Der Theologe Melanchthon, ed. Günter Frank (Stuttgart: Jan Thorbecke Verlag, 2000), 393-409, especially 393-94.

3 See Stefania Pastore, "Unwise Paths: Ignatius Loyola and the Years of Alcala de Henares," in Maryks, Companion to Ignatius of Loyola, $25^{-44}$.

4 See Carlos M.N. Eire, The Reformations: The Early Modern World, 1450-1650 (New Haven: Yale University Press, 2016), 289 and $45^{\circ}$.

5 See, for example, Francis M. Higman, La diffusion de la Réforme en France: 1520-1565 (Geneva: Labor et Fides, 1992) and Donald R. Kelley, The Beginning of Ideology: Consciousness and Society in the French Reformation (Cambridge: Cambridge University Press, 1981).

6 See Fabri monumenta, 490-697; Fontes narrativi, 2:127-40; 3:5-135; Bobadillae monumenta, $613-33$.

7 See, for example, Paul Warmbrunn, Zwei Konfessionen in einer Stadt:Das Zusammenleben von Katholiken und Protestanten in den paritätischen Reichstädten Augsburg, Biberach, Ravensburg und Dinkelsbühl (Wiesbaden: Franz Steiner, 1983). 
References to Ignatius's relationship to Reformers and Protestantism are also missing in his so-called autobiography, ${ }^{8}$ a narrative redacted by his close collaborators, including Luís Gonçalves da Câmara $(c .1520-75)$ and Jerónimo Nadal (1507-80), to tell the story of Loyola's religious vocation as a prototype of Jesuit vocation. It circulated in manuscript after his death until it was withdrawn by the third superior general of the Society Francisco de Borja (1510-72; in office $\left.15^{6} 5^{-73}\right)$ and replaced with Pedro de Ribadeneyra's (1526-1611) official biography (Latin edition in 1572 and the Castilian one in 1586). In this biography, Ignatius's preferred disciple highlighted the providential coincidence between Luther's summation by Emperor Charles V (1500-58, r.1519-56) to Worms and Ignatius's conversion in Manresa in 1521:

In 1521, driven by the Furies, [Luther] committed the high crime of openly declaring war on the Catholic Church. That was the very year in which God wounded Ignatius at the fort of Pamplona, to heal him and to make a brave leader out of that lowly slave to worldly vanity, opposing him to Luther as the fierce champion of his Church. ${ }^{9}$

The latter work reflects the new paradigm in Ignatian historiography that his close collaborators, it seems, began to construe toward the end of Loyola's life and especially after his death in 1556 . Indeed, various writings by Juan Alfonso de Polanco (1517-76) and Nadal reveal the same historiographical shift. They attempt to clear Ignatius and the still young Society (and perhaps themselves, being of converso background) of any suspicion of heresy. Their way of doing that was by highlighting the anti-Protestant character of the Jesuits.

In his defense of the Spiritual Exercises against the Dominican Tomás Pedroche's (d.1565) charges of heterodoxy from around 1556, Nadal wrote that Ignatius conceived the Society's entire institute against heretics, and especially "Lutherans." ${ }^{10}$ This is how he intended the expression "defense of faith" in Julius III's (r.1550-55) 1550 bull, which-as noted earlier-does not, however, refer explicitly to Protestantism. In his literary dialogue composed between 1562 and 1565 , Nadal parallels the origins of "Jesuitism" with the rise of Luther and compares the two leaders to David and Goliath. ${ }^{11}$ In his exhortation to

$8 \quad$ Fontes narrativi, 1:323-507.

9 Pedro de Ribadeneyra, The Life of Ignatius of Loyola, ed. Claude Pavur (St. Louis, Mo: Institute of Jesuit Sources, 2014), 119.

$10 \quad$ Fontes narr., 1:319, 322. In his exhortation at Alcalá, Nadal suggested that the Society was founded largely against the heretics of the time. See Nadal, Commentarii de instituto Societatis, 313-14.

Nadal, Commentarii, 607 . 
the Jesuits in Cologne (1567), Nadal compares Ignatius to the role the founders of the Dominicans and Franciscans had played in fighting against heresies of their times and notes a parallelism between Ignatius's conversion and Luther's "nefarious wedding,"12 which is imprecise, for Luther married Katharina von Bora (1499-1552) only in 1525. In his exhortation in Alcalá (1576), he is more precise in noting the synchrony between Ignatius's conversion and Luther's summation to Worms. ${ }^{13}$

In his life of Ignatius written between his exile from Rome in 1573 and his death in 1576, Polanco portrayed the co-founder of the Jesuits as a "new soldier of Christ" who began to serve "the heavenly king" following his vigil of arms at the Benedictine monastery in Montserrat toward the end of 1521 , the year in which Luther began to "throw his venom" against the Roman Apostolic See when summoned to Worms by Charles v. In Polanco's words, Ignatius's and his companions' special obedience to the pope would become an antidote to Luther's inobedience. ${ }^{14}$ There is no such comparison in his earlier summaria of Ignatius's life composed in the early years $(1547-51)$ of his tenure as the Society's secretary.

It seems that Polanco, Nadal, and especially Ribadeneyra (whose biography of Ignatius was actually printed and therefore had a wider circulation) influenced the next generation of Jesuit history writers. ${ }^{15}$ In his life of Ignatius commissioned by the fourth superior general Everard Mercurian (in office 1573-80), the Italian Giampietro Maffei (1533-1603) highlights the importance of the synchrony of the year 1521. Yet it must be said that "Lutheranism" is mentioned quite sparsely in his work. ${ }^{16}$ Similarly, in his history of the Society, the Italian Niccolò Orlandini (1554-1606) compares the dates of birth of Ignatius and Luther and mentions the death of the latter, but references to "Luther's venom" are rather scarce. ${ }^{17}$

\footnotetext{
$12 \quad$ Fontes narr., 2:403.

13 Nadal, Commentarii, 317.

14 Chronicon, 18 and Fontes narr., 2:522-23. The same parallelism had been used by Polanco in his Informatio de Instituto Societatis Iesu from 1564. See Fontes narr., 2:307.

15 Ribadeneyra's agenda of portraying the Society as a providential force to combat Protestantism was also expressed in his other publications, including his history of the "English schism." See Spencer J. Weinreich, Pedro de Ribadeneyra's Ecclesiastical History of the Schism of the Kingdom of England: A Spanish Jesuit's History of the English Reformation (Leiden: Brill, 2017).

16 See Giampietro Maffei, Historiarum Indicarum, in Maffei, Opera omnia (Bergamo: Petrus Lancellottus, 1747), 328, where bonsais are compared to Lutherans in "iniquity."

17 Historia Societatis Iesu (Cologne: Hierat, 1615), 3, 47, 85, 106-8, 128, 133, 148-49, 183, 209, 543 .
} 
The Italian Daniello Bartoli (1608-85) appears to be more explicitly in line with Polanco, Nadal, and Ribadeneyra in contrasting Ignatius and the Society with Protestantism. He describes Ignatius as a "valiant soldier" who was

carried out from the secular militia, to become the chief of a new militia, which, by means of other arms, and in a new species of warfare, was destined at once to serve the Church by its labors, and to defend her against the schism of Henry viII in England, the apostasy of Luther in Germany, and the revolt of Calvin in France. ${ }^{18}$

Unlike his Jesuit predecessors, Bartoli contrasts Ignatius not just with Luther but also with other leaders of Protestant groups and emphasizes the synchrony of 1521 and 1534 in the lives of Ignatius and Henry VIII (r.1509-47). He continues:

Ignatius and Calvin were in Paris at the same time, and both made disciples in that city. The first attached to himself a great apostolic laborer, whose life and doctrines were destined to crush heresy; while the second found a powerful supporter for the mass of errors which he desired to propagate. Finally Henry VIII. king of England, who had acquired in 1521, the glorious title of Defender of the Faith, published an edict in 1534, whereby be condemned to death whosoever should not efface the title of "Pope" from all the books or writings wherein it might happen to be inserted. That very same year, Ignatius was at Montmartre, carrying through the plan of an association destined especially for the defence of the Church, and of the Sovereign Pontiff. ${ }^{19}$

Similarly, in his history of the Society, the French Jesuit Joseph de Jouvancy (1643-1719) portrays Ignatius and the Society as the leader of a march against Protestantism, and mentions Calvin next to Luther. ${ }^{20}$

In the eyes of the contemporary Protestant writers, the main protagonist of this march was not Ignatius (who seemed to be unknown to Luther and other Reformers) but Canisius, whose catechism was discussed in 1556 by Flacius Illyricus (1520-75), a Lutheran Reformer from Istria. But the first Protestant,

18 Daniello Bartoli, History of the Life and Institute of St. Ignatius de Loyola, Founder of the Society of Jesus (New York: P.J. Kenedy, 1903), 15.

19 Ibid., 20. See also, for example, ibid., 77, 128, 192-93, 298.

20 Joseph de Jouvancy, Epitome historiae Societatis Jesu (Ghent: J. Poelman-De Pape, 1853), 62 . 
it seems, to write more specifically on the Jesuits was the famous German Lutheran theologian Martin Chemnitz (1522-86). In his Theologiae jesuitarum praecipua capita (Main points of the Jesuit theology, 1562), he describes the Jesuits as a papal offspring that invaded Germany, spreading their nests throughout. Chemnitz's historical reliability should, however, be questioned based on the sheer fact that he made Cardinal Pietro Carafa (later Pope Paul IV [r.1555-59]) the founder of the Society, whereas in reality he founded the Theatines and was rather at odds with Ignatius and his Society.

Chemnitz's anti-Jesuitism characterized the works of other Protestant writers at the beginning of the next century, including the Swiss Reformed theologian Rudolf Hospinian (Rudolf Wirth [1547-1626]) — who on more than four hundred folio pages of his Historia jesuitica describes the Jesuits as deceitful plotters against Protestants ${ }^{21}$ —and the Protestant from Basel Ludwig Lucius (or Luz [b.1577]). ${ }^{22}$ Interestingly enough, former Jesuits who turned Protestants also became authors of anti-Jesuit works in this period, among them the German Elias Hasenmüller (d.1587) who wrote a history of the Jesuit order (Historia jesuitici ordinis) that was published posthumously by his Protestant editor Polycarp Leyser II (1586-1633) in 1593. It defines the goal of the Jesuit foundation as resistance to heretics, especially the Lutherans. ${ }^{23}$

By the mid-seventeenth century, this myth of the anti-Protestant origins of the Society of Jesus seemed to have been well established, with the Flemish

21 Rudolf Hospinian, Historia jesuitica de iesuitarum ordinis origine, nomine, regulis, officiis, votis, privilegiis, regimine, doctrina, progressu, actibus ac facinoribus [...] (Basel: Typis Joh. Jacobi GenathI, 1627), available online at http://gateway.proquest.com/openurl?ctx _ver=Z39.88-2003\&res_id=xri:eebo\&rft_id=xri:eebo:image:9999o (accessed March 24, 2017). English translation: Rudolf Hospinian, The Jesuit's Manner of Consecrating Both the Persons and Weapons [...] (Dublin, 1681). Available online: http://eebo.chadwyck .com/home (accessed March 24, 2017). On Hospinian, see Martin Sallmann, "Hospinian (Wirth), Rudolf," in Religion Past and Present, at http://dx.doi.org/10.1163/1877-5888_rpp _SIM_10100 (accessed March 24, 2017). Admittedly, Hospinian had been influenced by the work of Hasenmüller (see below).

22 Ludwig Lucius, Jesuiter-Histori von des Jesuiter-Ordens Ursprung, Namen, Regulen, Beampten, Gelübden, Freyheiten Regiment Lehr, Fortpflantzung [...] (Basel: Genath, 1626), available online at https://archive.org/details/bub_gb_YOgVAAAAcAAJ (accessed March 24, 2017). Available online is also its Latin rendition, https://archive.org/details/bub _gb_9yRUAAAAcAAJ (accessed March 24, 2017).

23 Elia Hasenmüller, Historia iesuitici ordinis [...] (Frankfurt:Johannes Spies, 1593), 11. Republished together with Triumphus papalis in 1605. The German Jesuit Jakob Gretser (15621625) responded to Hasenmüller's publication with a long letter in which he defined his work as known for its dishonesty and ignorance. See Jakob Gretser, Epistola de historia ordinis Iesuitici scripta ab Helia Hasenmüller (Dillingen: Ioannes Mayer, 1594). 
Jesuit editors of the Imago primi saeculi (An image of the first century; Antwerp: Moretus, 1640), for instance, explaining that one of the reasons the Jesuits were founded was to defeat heretics, just as Francis (d.1226) and Dominic (d.1221) had defeated the Albigensian heresy in the thirteenth century. ${ }^{24}$ This myth traveled with European Jesuits and Protestants to all the colonies they established around the world, including Africa.

\section{Bibliography}

Bartoli, Daniello. History of the Life and Institute of St. Ignatius de Loyola, Founder of the Society of Jesus. New York: P.J. Kenedy, 1903.

Eire, Carlos M.N. The Reformations: The Early Modern World, 1450-1650. New Haven: Yale University Press, 2016.

Gretser, Jakob. Epistola de historia ordinis Iesuitici scripta ab Helia Hasenmüller. Dillingen: Ioannes Mayer, 1594.

Hasenmüller, Elia. Historia iesuitici ordinis [...]. Frankfurt: Johannes Spies, 1593.

Higman, Francis M. La diffusion de la Réforme en France: 1520-1565. Geneva: Labor et Fides, 1992.

Hospinian, Rudolf. The Jesuit's Manner of Consecrating Both the Persons and Weapons [...]. Dublin, 1681. http://eebo.chadwyck.com/home (accessed March 24, 2017).

Hospinian, Rudolf. Historia jesuitica de iesuitarum ordinis origine, nomine, regulis, officiis, votis, privilegiis, regimine, doctrina, progressu, actibus ac facinoribus [...]. Basel: Typis Joh. Jacobi GenathI, 1627. http://gateway.proquest.com/openurl?ctx _ver=Z39.88-2003\&res_id=xri:eebo\&rft_id=xri:eebo:image:9999o (accessed March 24, 2017).

Jouvancy, Joseph de. Epitome historiae Societatis Jesu. Ghent: J. Poelman-De Pape, 1853. Kelley, Donald R. The Beginning of Ideology: Consciousness and Society in the French Reformation. Cambridge: Cambridge University Press, 1981.

Lucius, Ludwig. Jesuiter-Histori von des Jesuiter-Ordens Ursprung, Namen, Regulen, Beampten, Gelübden, Freyheiten Regiment Lehr, Fortpflantzung [...]. Basel: Genath, 1626. https://archive.org/details/bub_gb_YOgVAAAAcAAJ (accessed March 24, 2017).

Maffei, Giampietro. Opera omnia. Bergamo: Petrus Lancellottus, 1747.

24 See Nienke Tjoelker, "Jesuit Image Rhetoric in Latin and the Vernacular: The Latin and Dutch Emblems of the Imago primi saeculi," Rencessanceforum 6 (2010): 97-118; and John W. O'Malley, S.J., ed., Art, Controversy, and the Jesuits: The Imago primi saeculi (1640) (Philadelphia: Saint Joseph's University Press), reviewed by Mia Mochizuki in the Journal of Jesuit Studies 3, no. 3 (2016): 488-91 (doi: 10.1163/22141332-00303008-02). 
Myers, William David. "Ignatius Loyola and Martin Luther: A History and Basis of a Comparison." In A Companion to Ignatius of Loyola: Life, Writings, Spirituality, and Influence, edited by Robert A. Maryks, 141-58. Leiden: Brill, 2014.

O'Malley, John W. S.J., ed. Art, Controversy, and the Jesuits: The Imago primi saeculi (1640). Philadelphia: Saint Joseph's University Press, 2015.

Pastore, Stefania. "Unwise Paths: Ignatius Loyola and the Years of Alcala de Henares." In A Companion to Ignatius of Loyola: Life, Writings, Spirituality, and Influence, edited by Robert A. Maryks, 25-44. Leiden, Brill, 2014.

Ribadeneyra, Pedro de. The Life of Ignatius of Loyola. Edited by Claude Pavur. St. Louis, мо: Institute of Jesuit Sources, 2014.

Tjoelker, Nienke. "Jesuit Image Rhetoric in Latin and the Vernacular: The Latin and Dutch Emblems of the Imago primi saeculi." Rencessanceforum 6 (2010): 97-118.

Vercruysse, Jos E. “'Melanchthon, qui modestior videri voluit [...]': Die ersten Jesuiten und Melanchthon." In Der Theologe Melanchthon, edited by Günter Frank, 393-409. Stuttgart: Jan Thorbecke Verlag, 2000.

Warmbrunn, Paul. Zwei Konfessionen in einer Stadt:Das Zusammenleben von Katholiken und Protestanten in den paritätischen Reichstädten Augsburg, Biberach, Ravensburg und Dinkelsbühl. Wiesbaden: Franz Steiner, 1983.

Weinreich, Spencer J. Pedro de Ribadeneyra's Ecclesiastical History of the Schism of the Kingdom of England: A Spanish Jesuit's History of the English Reformation. Leiden: Brill, 2017. 


\title{
Jesuits, Protestants, and Africa before the Twentieth Century
}

\author{
Festo Mkenda, s.J.
}

Sixteenth-century Africa was anything but a "dark continent" for the Jesuits. Their early missionary imagination clearly included Africa, and parts of the continent received Jesuits from as early as 1548. By 1561, Gonçalo da Silveira (1526-61) had penetrated the interior of southern Africa and had succeeded in baptizing one Monomotapa, king of the Shona people of today's Zimbabwe. Around the same period, a small band of Jesuits had entered the fabled land of Prester John, constituting the then unmapped Abyssinia, also known as Ethiopia Superior, and had succeeded in establishing a mission to Catholicize a country that was staunchly Orthodox. Mostly tormented and at times persecuted, that mission lasted for close to a century. Within the same sixteenth century, the Jesuits had made inroads into the old Kongo Kingdom, taking part in a Catholic mission that had already matured into a local church whose bishop had been the king's own son, Henry (c.1495-1531), described as the "first African bishop south of the Sahara." Similar Jesuit missions in Mozambique and Angola lasted until the Society was suppressed in Portuguese dominions in 1759.

Jesuits were not the only Catholic missionaries in Africa in that period. Other religious congregations also evangelized in regions that were under Portuguese influence. However, the Jesuit imprint on the so-called second wave of Christian evangelization of the African continent was significant. As Dr. Frederic Perry Noble (b. c.1863) — son of a Congregational pastor, a notable critic of Catholic missions in Africa, and secretary of the 1893 Chicago Congress on Africa-would put it, "He [the Jesuit], despite the activity of the Capuchin, Dominican, Franciscan, Lazarist and other orders, is the dominant figure in the missions of the sixteenth and seventeenth centuries. He compels us to center our vision on him until the coming of Lavigerie."2 Noble even refers to

1 John Baur, 2000 Years of Christianity in Africa: An African Church History, 2nd ed. (Nairobi: Paulines Publications Africa, 2009 [1994]), 59.

2 Frederic Perry Noble, The Redemption of Africa: A Story of Civilization, 2 vols. (New York: Young People's Missionary Movement, 1899), 1:361.

(C) FESTO MKENDA, S.J., 2018 | DOI 10.1163/9789004347151_003

This is an open access chapter distributed under the terms of the prevailing CC-BY-NC-ND License. 
Cardinal Charles Lavigerie (1825-92), founder of the Missionaries of Africa, as "the Loyola of Africa."

Africa's middle Christianity, in which Jesuits became such dominant players, extended from the beginnings of the padroado 4 in the fifteenth century to the waning of Portugal's exclusive patronage over the continent. That waning was well under way in the middle of the eighteenth century. Shortly after the Jesuits were sent away from Mozambique and Angola, Dominicans too were shown the exit door. Catholic missions in these parts of Africa disappeared almost completely and, together with them, any semblance of Catholicism beyond a few devotional items and practices, and ruins of churches. ${ }^{5}$

Although they left Protestants back in Europe, Jesuits of that second wave of evangelization never encountered their denominational competitors on the African soil, save for the brief but extremely interesting experience of Guy Tachard (1651-1712) and his companions in the midst of Dutch Calvinist colonists at the Cape in today's South Africa. ${ }^{6}$ Even if the Reformation in Europe influenced their missionary method and agenda, ${ }^{7}$ the Jesuits in Africa could go about their business as if Protestantism never existed. In Ethiopia, they campaigned to bring Orthodox Christianity into union with Rome; ${ }^{8}$ in eastern Africa, they lamented the ubiquity of Muslim obstruction; ${ }^{9}$ and in the western parts of south central Africa, they talked about indigenous religious practices

3 Ibid., 396.

4 The right of patronage granted to Portugal by popes according to which Portuguese kings took responsibility for the administration of local churches and missionary evangelization in newly acquired overseas territories.

5 David Livingstone and Charles Livingstone, Narrative of an Expedition to the Zambesi and Its Tributaries; And of the Discovery of the Lakes Shirwa and Nyassa, 1858-1864 (London: John Murray, 1865), 204.

6 Guy Tachard, A Relation of the Voyage to Siam: Performed by Six Jesuits Sent by the French King, to the Indies and China in the Year 1685 (Bangkok: White Lotus Press, 1999 [1688]), 33-80.

7 See Elias Kiptoo Ngetich, "Catholic Counter-Reformation: A History of the Jesuits' Mission to Ethiopia 1557-1635," Studia historiae ecclesiasticae 42, no. 2 (2016): 104-15; also John K. Thornton, "Afro-Christian Syncretism in the Kingdom of Kongo," Journal of African History 54, no. 1 (2013): 53-77, here 67-68, and Thornton, "Conquest and Theology: The Jesuits in Angola, 1548-1650," Journal of Jesuit Studies 1 (2014): 245-59, here 250.

8 Jerome Lobo, A Voyage to Abyssinia, trans. Samuel Johnson (London: Elliot and Kay, 1789), 79; also see "Introduction" to Some Records of Ethiopia, 1593-1646: Being Extracts from The History of High Ethiopia or Abassia by Manoel de Almeida Together with Bahrey's History of the Galla, trans. and ed. C.F. [Charles Fraser] Beckingham and G.W.B. [George Wynn Brereton] Huntingford (Aldershot: Ashgate, 1954), xxi-xlix, here xxi.

9 See Hubert Chadwick, Life of the Venerable Gonçalo da Silveira of the Society of Jesus: Pioneer Missionary and Proto-martyr of South Africa (London: Manresa Press, 1910), 89-91. 
and wondered whether or not they could be accommodated into their version of Christianity. ${ }^{10}$ At that time, Protestantism may have been imagined as a formidable foe, but, for Jesuits in Africa, it was one that was far away.

Then still in their first centuries of existence, Protestants busied themselves building foundations in northern Europe while Catholics explored new grounds in Africa, Asia, and the Americas. ${ }^{11}$ The objective of the Propaganda Fide, established in 1622 , is to be understood within these parameters: not only "to regain the faithful in all those parts of the world where Protestantism had been established" but also "to bring the light of the true faith to heathen lands." And this was to be achieved partly by organizing "into an efficient corps the numerous missionary enterprises for the diffusion of the Gospel in pagan lands." ${ }^{12}$ In the imagination of sixteenth- and seventeenth-century Europe, Africa was the quintessential "pagan land," and Jesuits stepped forward with determination to tame the African religious wildness, even "up to [the point of] shedding blood and being sacrificed for the faith."13

Protestants, then hardly organized for missions, would only encounter Jesuits of this period in Africa in retrospect as they passed comment on their earlier achievements, sometimes admiring them and sometimes disparaging them. The failure of the Church Missionary Society (CMs) to make headway in Ethiopia in the early nineteenth century would, for example, be blamed on "the intrigues of the Jesuits" as discerned in the tales of their missions in that country in the sixteenth and seventeenth centuries. ${ }^{14}$ Toward the end of the nineteenth century, a Protestant critic of the Jesuits would write more generally that

while the Mission field was almost exclusively in the hands of Rome, the Jesuits, in the teeth of the Papal authorities, did much as they pleased;

$10 \quad$ See Thornton, "Conquest and Theology," 68-70.

11 See Diarmaid MacCulloch, A History of Christianity: The First Three Thousand Years (London: Penguin Books, 2009), 216.

12 Peter Guilday, "The Congregation de Propaganda Fide (1622-1922)," Catholic History Review 6 , no. 4 (1921): $47^{-}-94$, here 48 o.

13 See words of the caption in Latin of a seventeenth-century allegorical engraving of Africa from Matthias Tanner (1630-92), Societas Jesu usque ad sanguinis et vitce profusionem militans [...] (Prague, 1675); see Festo Mkenda, "Jesuits and Africa," Oxford Handbooks Online, available online at http://www.oxfordhandbooks.com/view/10.1093/ oxfordhb/9780199935420.001.00o1/oxfordhb-9780199935420-e-56 (accessed June 24, 2017).

14 Malta Protestant College, Journal of a Deputation Sent to the East by the Committee of the Malta Protestant College in 1849 [...], 2 vols. (London: James Nisbet and Co., 1854), 2:849-50. 
their contentions hardly reached the outside world in any shape; there was then no public opinion to consider. Now the case is different. The various Missions of Rome are working in the same fields with Protestants; they are under constant surveillance, and whatever amount of bitterness or jealousy may exist among the rivals, it has, as far as possible, to be suppressed in the face of what they deem the common enemy. ${ }^{15}$

That description of a shared missionary field, mutual surveillance, and a combination of bitterness and jealousy that was sometimes tempered with the necessity of collaborating in a foreign milieu viewed as a common enemy perfectly suits the next wave of evangelization in Africa, which started toward the end of the eighteenth century and became intense in the nineteenth.

By this time, Portugal had already lost its exclusive hold on Africa, and more colonizing nations of Europe were bidding to acquire portions of the continent. Concomitantly, shades of Christianity other than Catholic and Orthodox were also seeking a foothold in Africa. This third wave of evangelization was pioneered by Protestants. They had just organized themselves for the missions, and Africa was clearly in their sights: 1792 saw the beginnings of the Baptist Missionary Society (BMS) under William Carey (1761-1834); the London Missionary Society (LMS) (bringing together Methodists, Presbyterians, and Congregationalists) started in 1795; the CMS started in 1799; the British and Foreign Bible Society (вғBS) started in 1804; and the Universities Mission to Central Africa started around 1857. These organizations sent missionaries to Africa, opening the era of multidenominational evangelization that continues to mark African Christianity to this day. "The year 1792 may be taken as the starting point of the epoch," observes historian John Baur (1920-2003), as "it saw the foundation of the first Protestant missionary society to work in Africa, the Baptists; the definitive establishment of the first mission in South Africa, the Moravian Genadental [sic]; and the foundation of Freetown in Sierra Leone as a base of Protestant mission work in West Africa."16

Protestant pioneering gives credence to the argument that, at least partly, Catholics resumed missionary activity in Africa in the nineteenth century in order to challenge a growing Protestant monopoly over the continent. ${ }^{17}$

$15 \mathrm{~K}$, "On the Character of Jesuit Missionary Teaching," Church Missionary Intelligencer and Record (July 1886): 529-45, here 543 .

16 Baur, 2000 Years of Christianity, 101.

17 See Ronald Werner, William Anderson, and Andrew Wheeler, Day of Devastation, Day of Contentment: The History of the Sudanese Church across 2000 Years (Nairobi: Paulines Publications Africa, 200o), 131; also see Noble, Redemption of Africa, 369 . 
While Protestant missionary societies were mostly organized by lay men and women, Catholics looked to clerical societies and to religious congregations for labor in mission territories. Many of them started in the nineteenth century and quite a few specifically focused on Africa: in 1802, the Holy Ghost Fathers, previously suppressed during the French Revolution, were restored by Napoleon Bonaparte (1769-1821) to educate the clergy for French colonies; in 1807, the Sisters of St. Joseph of Cluny were founded to serve in Africa and Asia; in 1814 , the Society of Jesus was restored; in 1841, Fr. Francis Libermann (1802-52) founded the Congregation of the Holy Heart of Mary specifically for the conversion of "Negroes"; in 1856, the Society of African Missions was founded by Melchior de Marion Brésillac (1813-59); in 1862, the Congregation of the Immaculate Heart of Mary (the Scheut Fathers); in 1866, the Mill Hill Fathers; in 1867, the Comboni Missionaries, specifically for missions in Sudan; in 1868, the White Fathers or Society of Missionaries of Africa, and in 1869, the Missionary Sisters of Our Lady of Africa, both founded by Lavigerie; and in 1875, the Society of Divine Word.

This combined Protestant and Catholic focus on nineteenth-century Africa led to a veritable missionary scramble not too different from the political scramble that preceded formal colonial occupation in that same century. Commenting on Catholic success in that scramble, Noble says the Catholic Church partitioned Africa into a number of ecclesiastical jurisdictions. Reporting on the same phenomenon, the mission-magazine of the Scotch Free Presbyterians stated that "whatever one might think about the papacy he could not but admire the daring of its schemes for the conquest of Africa."18 Indeed, while we can identify only around fifteen Catholic ecclesiastical jurisdictions in the whole of Africa from the first century of Christianity to the end of the eighteenth century, between 1818 and 1906 we can count up to sixty-six similar jurisdictions under different titles (mission, prefecture apostolic, vicariate apostolic, bishopric or archbishopric, diocese) under the care of twenty-one different missionary groups. ${ }^{19}$

Whether Catholics or Protestants, "missionaries were expected to carry and brandish the national flag," ${ }^{20}$ a fact that added a tint of patriotism to their competition for African souls. Even if violent encounters did not occur, subtle understatements and outright disparagements betray the disdain with which Christians of different denominations treated each other in Africa.

\footnotetext{
18 Noble, Redemption of Africa, 402.

19 See "Catholic Africa" in Catholic Encyclopedia, 1913 edition.

20 John W. O'Malley, A History of the Popes: From Peter to the Present (Lanham, MD: Sheed \& Ward, $2011[2010]), 251$.
} 
Commenting on early nineteenth-century Protestant missions in Algeria, for example, Thomas William Marshall (1818-77), himself a convert from Anglicanism, says the assertion that through Protestant preaching "many a son of Abraham had been made acquainted with the Redeemer" amounts to nothing more than "the statement, that several hundred copies of the Holy Scriptures had been circulated." ${ }^{21}$ Elsewhere, he retells an allegation, attributed to an Ethiopian Orthodox cleric, that Bibles distributed by Protestants ended up being used for "the wrapping up of snuff."22 Rather gleefully, he writes about a Protestant project in Algiers "to 'erect an edifice' for a church, which [...] would effectually stop 'the taunt in the mouths of the French Roman Catholics against British Protestants," yet whose results did not measure up to their lofty hopes. ${ }^{23}$ Lamenting what he viewed as English Methodists' interference with Catholic chances to unite Alexandria with Rome, Marshall summarily concludes: "It is the mission of Protestantism to scatter and destroy."24

Marshall's chapter on missions in Africa, written in 1862 and spanning 132 pages, was designed to provide a comprehensive overview of the subject from a Catholic point of view. As such, it contrasts sharply with that of Noble, written around 1899. Noble, who wrote on the same subject from a Protestant perspective, knew Marshall's work and referred to its author as "a professional apologist for papal missions." ${ }^{25}$ His fifty-eight-page chapter entitled "Rome in Africa" contains twenty-two pages entirely dedicated to the Jesuits and aptly subtitled "The Societas Jesu and Africa." Writing at the height of the political and economic scramble for Africa, ${ }^{26}$ Noble reveals the patriotic tint that characterized encounters between Catholics and Protestants in Africa. "France abroad has since the fall of Spain been the strong son of the church and uses papal missioners as political agents," argued Noble, citing Les missions catholiques for an affirmation "that French missioners 'go from pole to pole to teach knowledge and love of France as well as of the church."'27 In his narrative, the height of the nationalistic competitions is best seen in Uganda where "French priests arrived avowedly to oppose the Protestants by promulgating the truth as

\footnotetext{
21 Thomas William Marshall, Christian Missions: Their Agents, their Method, and their Results, 3 vols. (London: Burns and Lambert/H. Goemaere, 1862), 2:306-7.

22 Ibid., 347.

23 Ibid., 307.

24 Ibid., 309. The pages following this contain Marshall's diatribe against the Protestants, especially lamenting their conduct in Egypt and in other parts of Africa.

25 Noble, Redemption of Africa, 376.

26 See Thomas Pakenham, The Scramble for Africa 1876-1912 (London: Weidenfeld and Nicolson, 1992).

27 Noble, Redemption of Africa, 403.
} 
understood by members of their creed." The French priests, he says, "never concealed their enmity, if not to the Englishmen, [then] to their teachings." 28 "The Algerine [White] Fathers, apart from their religious objects, were notoriously part of a plan to extend French influence," he further argues, which leads him to the conclusion "that the French priests were intended to win Uganda for France and to destroy the Protestant mission."29 Interestingly, the CatholicProtestant contest in Uganda was momentarily resolved by drawing denominational boundaries that were clearly marked by nationalistic sentiments, as Noble observes:

Not until Lugard took possession for the British company, did order come from chaos. The outcome of the horror is that in 1892 the agents of France and Rome were assigned with their converts to Buddu province, while Uganda proper was set apart for the Protestants. Cardinal [Herbert] Vaughan [1832-1903] afterward agreed to send missioners trained in his college to work with their French fellow Catholics, and it was hoped that this arrangement would remove the racial difficulty; but it failed of the success expected, and now Rome is replacing her Frenchmen wholly with English Catholics. The French realize the force of pax Britannica, and are convinced that Uganda belongs to Britain. ${ }^{30}$

More specifically to Jesuits, patriotic sentiments of this nature manifested themselves vividly in Madagascar, where mainly French Jesuits competed with mainly English Protestants for control of the local political establishment; and in Congo, where Protestants of different nationalities decried a close association between Belgian Jesuits and the Belgian colonial administration. In the latter case, Jesuits were perceived to be receiving material favors from the state in exchange for silence over state-sanctioned atrocities against native Africans. ${ }^{31}$

\section{$28 \quad$ Ibid.}

29 Ibid., 404.

$30 \quad$ Ibid., 409-10. Lord Frederick Lugard (1858-1945) was hired by the Imperial East Africa Company in 1889 and, in the following year, "the company sent him to establish its authority in the Kingdom of Buganda in today's Uganda. There he intervened in a civil war among Ganda religious factions and persuaded Apolo Kagwa and other Ganda chiefs to accept British protectorate." Mark R. Lipschutz and R. Kent Rasmussen, Dictionary of African Historical Biography, 2nd ed. (London: University of California Press, 1986), 126.

31 See Marvin D. Markowitz, "The Missions and Political Development in the Congo," Africa: Journal of the International African Institute 40, no. 3 (1970): 234-47. 
As should be clear by now, in the missionary competitions that marked the nineteenth century, Jesuits were neither the only Catholic players in Africa nor the most dominant ones. Of the sixty-six ecclesiastical jurisdictions mentioned above, Jesuits manned only three: the vicariate apostolic of Central Madagascar, erected in 1848; the Zambezi mission, erected in 1879; and the Kwango mission in today's Democratic Republic of Congo (D RC), erected in 1892. However, these were vast missionary territories. The Zambezi mission, for example, was intended to cover most of southern Africa below the Equator. Moreover, as we cross to the twentieth century, Jesuit activity in Madagascar and in the DRC spread far beyond their initial centers. It follows that significant encounters between Jesuits and Protestants are to be observed within these three regions, and some of them are treated more specifically by different authors in the present volume. A more general look at the encounters could be narrowed down to six items that either forced Jesuits and Protestants to encounter one another or called for comment from one side about the other: memory, territory, government, people, theology, and method.

As already discussed, Jesuits had been in Africa in earlier centuries. While Jesuits themselves remain largely silent about this part of their history, other Catholics and Protestants dug out their memory and debated their legacy. Viewed through Catholic eyes, and with emphasis on the challenging context of the time, the first Jesuit experience in Ethiopia, Mozambique, and Angola was largely successful and its protagonists were heroes if not martyrs. ${ }^{32}$ Jesuits themselves felt comfortable with this Catholic point of view. Conversely, viewed through Protestant eyes, the experience was almost a complete failure. To cite Noble again, Jesuit converts in Africa "were but the most nominal Christians," and the Jesuit missionary system was "rotten from cornerstone to turret." ${ }^{33}$ Nearly all Protestant authors make reference to Jesuit implication in the slave trade as one reason for their failure in Angola and Mozambique. Yet, Protestant adherence to the Christianity-commerce-civilization triad as constituting a single missionary package ${ }^{34}$ forced even the loudest critic of the Jesuits to single out things they might have gotten right in earlier

32 Marshall, Christian Missions, 322-28; also see Jean Baptiste Coulbeaux, Histoire politique et religieuse de l'Abyssinie depuis les temps les plus reculés jusqu'à l'avènement de Ménélick II, 3 vols. (Paris: Geuthner, 1928), 2:132-63.

33 Noble, Redemption of Africa, 372.

34 Cf. Andrew Porter, Religion versus Empire? British Protestant Missionaries and Overseas Expansion, 1700-1914 (Manchester and New York: Manchester University Press, 2004), 92-96; also see David Livingstone, David Livingstone and Cambridge: A Record of Three Meetings in the Senate House (London: Universities Mission to Central Africa, 1908), 9, 12-13. 
times, mainly education of native Africans ${ }^{35}$ and direct involvement in agriculture and commerce. ${ }^{36}$

In the nineteenth century, shared territory became another cause of JesuitProtestant encounter in Africa. To the missionary, Africa was an open field, a territory free to be grabbed. Whoever arrived first was inclined to claim exclusive rights to evangelize within a given geographical area and to view the next Christian comer as an intruder. However, neither Jesuits nor Protestants were able effectively to cover the mammoth territories they had mapped for themselves. In 1905, Joseph Moreau (1864-1949), one of the Jesuit pioneers in Zambia, would muse: "Very few then realized the vastness of the territory assigned to the Zambezi Mission. Who was to undertake a work of such magnitude as to evangelise this vast territory?" Moreau observed that "Catholic and Protestant missionaries had already established Mission Stations in the Cape Colony, Natal, and Basutoland." Moreover, the "London Mission Society had a wellestablished mission station among the Bechwana [...] [and] Rev. Moffat and family had settled at Inyati [among the Matabele]." He further observed that, northward beyond the Zambezi, "among the Barotse, no missionary had as yet got a foothold." The decision of the Propaganda in Rome to erect the Zambezi mission was not only for the purposes of reaching where no missionary had yet gotten a foothold but "for the evangelization of those vast territories which had not yet been contacted by the Catholic Church, and only slightly so by the Protestants." ${ }^{37}$ In fact, Jesuit attempts to settle in present-day Zambia, which started in the late nineteenth century but succeeded only in 1905, were interferences in regions that had been more than just slightly contacted by Protestants. ${ }^{38}$ Making reference to the experience in the realm of Chief Khama III (c.1835-1923, r.1872-73, 1875-1923) of the Bangwato people of central Botswana, Noble complained that the Jesuits "had long known that Shoshong was the headquarters of the British Congregationalists in the interior," but still "aimed

35 See Isaac Schapera, ed., David Livingstone: Family Letters 1841-1856, 2 vols. (London: Chatto \& Windus, 1959), 2:255; also see Noble, Redemption of Africa, 372.

36 See David Livingstone, Missionary Travels and Researches in South Africa: Including a Sketch of Sixteen Years' Residence in the Interior of Africa (London: Ward, Lock \& Co., 1857), 346; Schapera, David Livingstone, 2:277; Noble, Redemption of Africa, 380.

Joseph Moreau, "The Chikuni Mission: How It Came to Be" (unpublished manuscript dated 1905, copy at the Jesuit Historical Institute in Africa), 1-2; also see Michael Gelfand, ed., Gubulawayo and Beyond: Letters and Journals of the Early Jesuit Missions to Zambesia (1879-1887) (London: Geoffrey Chapman, 1968), 18-19.

38 See Reinhard Henkel, Christian Missions in Africa: A Social Geographical Study of the Impact of Their Activities in Zambia (Berlin: Dietrich Reimer Verlag, 1989), 28-32. 
to plant a Jesuit station among the Mangwato."39 Under such circumstances, it was inevitable that Jesuits and Protestants would rub together in the territories they sought to evangelize.

Territory and government were closely linked. Generally, the task of governing in nineteenth-century Africa was carried out by chiefs of various ranks. In order to settle and evangelize in a particular area, missionaries had to deal directly with these chiefs. Their success or failure depended heavily on the favor or ill-will of the chiefs. Moreover, as historian Stephen Neill indicates:

Various motives encouraged chiefs to permit the presence of missionaries among their people. Some were clever enough to recognize that a white man might be useful as a safeguard against the ever-encroaching menace of his fellow-countrymen. Others regarded him merely as a convenient milch-cow from whom endless gifts and tribute could be extracted. Others again liked to have a tame missionary about the place as they might equally well have liked to have a tame elephant. But, whatever the motive, without the approval of the chief residence was impossible, and, even if residence was permitted, the acquisition of land on anything like a permanent tenure was always a matter of the utmost difficulty. 40

As long as they went to the same places, Jesuits and Protestants had to deal with the same chiefs. The chief became the point of their encounter and, in many ways, the arbitrator between them.

In allocating land, the chief decided who settled where in order to separate competing missionary interests. Moreau's narrative of the first Jesuit encounter with Chief Khama is of interest in this regard. Khama was already a Christian aligned to the LMs. When Jesuits approached him for permission to settle and preach, Khama

answered that he had already the missionaries of the London Missionary Society, that either Fr. Depelchin's missionaries would teach the same doctrine, and therefore would be no new acquisition, or they would teach a different one, and thereby bring disunion among his people, and would in such a case be worse than useless. ${ }^{41}$

39 Noble, Redemption of Africa, 387.

40 Stephen Neill, A History of Christian Missions (Harmondsworth: Penguin, 1964), 371.

41 Moreau, "Chikuni Mission," 4. Henri Depelchin (1822-1900) was the first Jesuit superior of the Zambezi mission. 
From Khama's territory, the Jesuits proceeded to Chief Lobengula (c.1836-94, r.1870-94) of the Ndebele people in today's Zimbabwe. Here, according to their host, they could stay, repair his wagon, teach his people different trades, and even repair guns, "but not teach his people any doctrine that condemned the laws or customs of his country." The Jesuits, like the Protestants who had arrived in Matabeleland before them, were forced to sit and wait for better times. ${ }^{42}$ In fact, it has been argued that "Lobengula used his experience with Protestant missionaries and European traders to develop an effective strategy that severely limited the efficacy of the Jesuits' efforts." ${ }^{33}$ The Jesuits also visited Chief Lewanika (c.1842-1916, r.1878-84, 1885-1916) of the Lozi people in today's Zambia, first in 1880, when they found him disposed to their mission, then in 1883 , when he was no longer interested in them. Their conclusion: "Influences had been at work meanwhile pre-disposing him against the Catholic missionaries and inclining him towards the Protestants." 44

At some point, missionaries all over Africa were of the opinion that "better times" could be made to come faster than they would naturally do. Jesuits and Protestants in southern Africa came to view obdurate African chiefs as irritants if not outright obstacles to the Gospel. Historian James Morrison would describe the African "tribal chief" as "often a cruel, bloodthirsty and licentious tyrant who ate up his people." ${ }^{45}$ Such chiefs kept their people out of the missionary's reach, ${ }^{46}$ it was thought, yet it was the African native that the missionary wished to evangelize. Noble, the avowed critic of Catholic missions in Africa, would say that the "Jesuits also believed, and rightly, that the difficulty of missions among the Tabili [Ndebele] lay in the government rather than the subject [...]. If despotic institutions could be relaxed, here was a soil capable of fruit." He further cites Alfred Weld, s.J. (1823-90) as having "thought it 'probable that if we set aside the influence of despotic rule, which may itself be turned to good, the field is more hopeful than that of the Parana and Uruguay which produced so rich a harvest." 47 Obviously, an alternative to the despotic chiefs was a colonial administration that would provide protection for missionaries, freedom for the native African to convert, and freedom of religion to

\footnotetext{
42 Neill, History of Christian Missions, 4-5.

43 Nicholas M. Creary, Domesticating a Religious Import: The Jesuits and the Inculturation of the Catholic Church in Zimbabwe, 1879-1980 (New York: Fordham University Press, 2011), 26.

44 Moreau, "Chikuni Mission," 9.

45 J.H. [James Horne] Morrison, The Missionary Heroes of Africa (New York: George H. Doran Company, 1922), 21.

46 See Creary, Domesticating a Religious Import, 27.

47 Noble, Redemption of Africa, 390-91.
} 
Catholics and Protestants akin to what had become commonplace in Europe and America at that time. Again, a typical example of this case is that which involved Lobengula. Through a concession that was wrongly interpreted and explained to him by Rev. Charles Helm (1844-1915) of the LMS, the chief had allegedly paved the way for Cecil Rhodes's (1853-1902) British South Africa Company (BSAC) that enjoyed the services of Jesuit chaplains to occupy and administer territories far beyond his own control.48 "You've done a good day's work for Rhodes, padre, and he won't forget it; a good day's work for your mission too," said James Maguire (1855-1945), one of the negotiators of the 1888 Rudd Concession, in gratitude to the Protestant missionary misinterpreter. ${ }^{49}$

The Ndebele did resist the colonial take over implied in the Rudd Concession, but they were subdued through military campaigns in 1893 and 1896, which also enjoyed Jesuit chaplaincy. "The Catholic [read: Jesuit] priest had the privilege of being present at all these engagements," reported Marcus Barthélemy, S.J. (1857-1913), who also noted that the Catholic chaplain catered for the spiritual needs of Protestants and "heathens" as well:

The Protestant was glad to see near him the minister of God and to be helped to form a good act of faith and of contrition before appearing at the tribunal of God; the Catholics received the precious sacraments which our Holy Mother Church dispenses to her dying children, and several poor heathens of our native contingent were privileged to receive baptism before they succumbed to their wounds. ${ }^{50}$

In the end, not only Protestant missionaries benefited from the establishment of the BSAC-controlled colony of Rhodesia; Jesuits also "received extensive land grants to establish permanent mission stations in and around Salisbury and Bulawayo." ${ }^{1}$

Establishment of colonial administration also facilitated greater access to native Africans, the people that were the target of Catholic and Protestant evangelization. Despite their disapproval of each other's doctrines, "both sects had the same object in view, that of bringing a better life to the African,"

48 See ibid., $25,31^{-32 .}$

49 Hugh Marshall Hole, Lobengula (London: Philip Allan \& Co., 1929), 152-53.

5o Marcus Barthélemy, "During the Matabele Wars," Zambesi Mission Record 1 no. 1 (1898): 19-21, here 21.

$5^{1}$ Creary, Domesticating Religious Import, 32; also cf. Moreau, "Chikuni Mission," 10-11; Noble, Redemption of Africa, 383; Brendan P. Carmody, Conversion and Jesuit Schooling in Zambia (Leiden: Brill, 1992), 27. 
contends physician and historian Michael Gelfand (1912-85).52 Both targeted the same groups of people: the Ndebele, the Shona, the Tonga, the Lozi, and so on. As they competed for the same souls, Jesuits and Protestants had to prove their worth before the African. "Of course it can be argued that this competition had its advantages," says Gelfand, "for the presence of one group inevitably encouraged the efforts of the other and so their missionary activities were double." 53

In the main, Jesuits and Protestants had a shared view of the African as a heathen and an object of their separate civilizing missions. Greater access to people implied greater acquaintance with the cultures and traditions that the missionaries considered so antithetical to their Gospel. The missionary industry that is evident in the study of local languages, the translation of scriptures, and the documentation of native customs is an example of this increased acquaintance. The missionaries arrived at fairly similar conclusions and held the same theological views regarding African religious dispositions. As has been argued in a different context, nineteenth-century missionaries

identified Christianity with the moral standards of their own middleclass background at home, and anything which deviated from these standards, they regarded as sinful and deplorable and to be eradicated. They had very little appreciation or respect for the customs and traditions of the people. They condemned dancing, sports, smocking and many other innocent habits of the people, and regarded them as harmful to Christianity and therefore forbidden to the members of the society. ${ }^{54}$

Despite their overall reputation as generally tolerant of other cultures and, as such, ahead of their time on matters of inculturation, ${ }^{55}$ Jesuits struggled with certain elements of traditional African society. Reporting on the "Kaffirs" of South Africa, Charles Bick, S.J., (1861-1939) reduced these to the practice of polygamy, the relationship with ancestral spirits, and the belief in malevolent forces of witchcraft and sorcery. ${ }^{56}$ Protestants shared in this theological assessment. Talking about the same group of native Africans, Bishop Joseph Watkin Williams (1857-1934) of the Anglican diocese of St. John's, Kaffraria, declared

$5^{2}$ Gelfand, Gubulawayo and Beyond, 20.

53 Ibid.

54 Sione Latukefu, "The Case of the Wesleyan Mission in Tonga," Journal de la Société des océanistes 25 no. 25 (1969): 95-112, here 97.

55 Cf. Thornton, "Conquest and Theology."

$5^{6}$ Charles Bick, "The Missions of Kaffraria," Zambesi Mission Record 1, no. 1 (1898): 27-34. 
polygamy to be "undoubtedly the most formidable question with which the missionary has at present to deal."57

The seeming theological unanimity just described did not create communion, however. There were significant Catholic and Protestant voices blaming the opposite side for allowing too much of African practice into Christianity. Robert Sykes, S.J. (1854-1920), twice superior of the Zambezi mission, dismissed the Protestant native as one who "seems to have inherited with his reception into the Christian body, a double dose of original sin," becoming worse than he or she was in his or her "heathen" state. "If this is the result, what is the value of missionary effort, and why teach the native 'Christianity' at all?" asked Sykes. ${ }^{58}$ His question almost lends credence to Noble's complaint that Catholics "believed it better the natives should remain heathens than imbibe [Protestant] heresy" ${ }^{59}$ In Catholic eyes, Noble would argue, Protestantism was a heresy, and Catholic "entrance into Protestant mission-fields is an inevitable, logical outcome from her principle and practice of including Protestant heretics with heathen lands." ${ }^{\circ 0}$ However, Noble also viewed the work of the Protestant missionaries as being far more effective than that of their Catholic counterparts. For him, "the Jesuit was lax or strict according to circumstance, a moral chameleon" whose objective "was to drive no person from the church." Consequently, "since there are bad people, it is better they should be poor Catholics than wicked Protestants, a sentiment many non-Romanists will endorse in a sense the reverse of that intended by Jesuistry." ${ }^{\prime 1}$ It is no surprise that, as was noted earlier, Noble himself viewed the Jesuits' African converts as the most nominal of Christians. "Rome was numerically more powerful," he argued, "but the weight of character and influence rested with the Protestants." 62

Finally, Jesuits and Protestants commented on each other's missionary methods, sometimes commending them, other times disapproving of them. For example, there was a certain understanding among Jesuits, shared by other Catholics as well, that Protestants used money to advance their course, and

57 The bishop of St. John's, Kaffraria, "Law and Customs of Marriage in Non-Christian Lands (S. Africa or Africa) as Bearing on Mission Difficulties," in Pan-Anglican Congress, The Church and Human Society: Speeches and Discussions together with the Papers Published for the Consideration of the Congress (London: Society for Promoting Christian Knowledge, 1908), Part 2, 13-20, here 13 .

58 Robert Sykes, "Protestant Missionary Activity in South and Central Africa," Zambesi Mission Record 1, no. 1 (1898): 11-15, here 11.

59 Noble, Redemption of Africa, $402-3$.

6 o Ibid., 363 .

61 Ibid., 372.

62 Ibid., 409. 
that they had a lot of it. According to Sykes, Protestant "propaganda" was "supported by immense sums of money annually contributed by charitablydisposed Protestants at home, which are not, as far as I am aware, restricted to any particular sect, but a proportion of which finds its way into the coffers of the different missionary bodies in Africa." ${ }^{63}$ But, starting with David Livingstone (1813-73), ${ }^{64}$ nearly all Protestants in Africa also believed that Jesuits had incredible amounts of wealth. "The Societatis Jesu is fancied to be inordinately wealthy," wrote Noble several decades after Livingstone. ${ }^{65}$ More generally, some of them believed that the Propaganda Fide poured immeasurable sums of money into missions, so much so that apparent nineteenth-century Catholic success in places like Ethiopia was attributed "principally to bribery and corruption." 66

While we may never settle the argument about who had more wealth, we may safely conclude that both Jesuits and Protestants used money and other resources to establish the "missions" or "mission stations" that had become the preferred locus of Christian activity, together with the schools and hospitals that were constitutive elements of those missions and stations. ${ }^{67}$ Some Protestants would argue that Jesuit missionary method went beyond the mission-station model to establish "Christian villages." The fullest development of this Jesuit structure in Africa was seen in the so-called "chapel-farms" in Congo, which were created exclusively for the youth, with each consisting of a chapel, a missionary lodge, a farm, and accommodation for children and for a few married couples that were meant to be role models for the targeted boys and girls. The "chapel-farms" attracted a lot of criticism from Protestants who viewed them as a re-creation in Africa of the "reductions" of Paraguay, a charge the Jesuits denied vehemently. ${ }^{68}$

Given the mutual suspicion between Catholics and Protestants in Africa, a general overview like this can easily fail to notice moments of friendship, support, collaboration, and appreciation that were not entirely lacking among the missionaries across the denominational divide. Despite his critical stance against anything Protestant, for example, Marshall could still describe a certain

63 Sykes, "Protestant Missionary Activity," 12.

64 Livingstone, Missionary Travels, 551.

65 Noble, Redemption of Africa, 367.

66 John Wilson, The Lands of the Bible, 2 vols. (Edinburgh: William Whyte \& Co., 1847), 2:593.

67 Henkel, Christian Missions in Africa, 24-25.

68 Noble, Redemption of Africa, 383; also see "The Catholic Missions in Belgian Congo: A Statement of Facts," The Tablet 119, no. 3741 (January 20, 1912): 106-10, and Emile Thibaut, Les fermes-chapelles: A propos d'un débat recent (Brussels: Goemaere, 1911). 
Mr. Bell, who was an English Protestant, as "friend and protector" of Catholic missionaries. ${ }^{69}$ In so doing, Marshall revealed a close racial or cultural affinity among missionaries of various denominations as they encountered one another in what was to them a hostile environment populated by strange peoples with foul cultures. The competent guide of the Jesuits' caravan across Tongaland was one Mr. Walsh Pan, an Irish Protestant married to a Catholic wife, whom the Jesuits later re-baptized into Catholicism while he was in danger of death. ${ }^{70}$ Catholics too performed charitable acts toward their Protestant counterparts. Noble tells us that, when the Presbyterian bishop Alexander Mackay (1849-90) died in Uganda, "a papal missionary was hastening as a good Samaritan to nurse him."71 Moreover, although Noble criticized the Jesuits, he ultimately viewed them in a more positive light than other Catholic missionary groups: "While the Jesuits developed the positive qualities of energy," he said, "the Capuchins gave expression to the negative qualities of ignorance, credulity and coarse sympathy with the lower instincts of the masses. ${ }^{72} \mathrm{He}$ even defended Jesuits against the now accepted charge that, in Africa, they engaged in or tolerated the slave trade, proposing instead that the charge "is probably as false as the modern scandals occasionally retained against their Protestant brethren."73

To a contemporary ear accustomed to hearing about positive efforts toward ecumenism, the largely fractious encounters between Jesuits and Protestants in Africa may be surprising. Yet, ecumenism, implying unity among Christians pursued across the boundaries of creed, ritual, and polity, is a twentieth-century phenomenon. Although Protestant missionary associations in the nineteenth century showed remarkable interest in interdenominational collaboration, it was still unthinkable that Catholics and Protestants could come together on matters that had implications for doctrine. Nineteenth-century Jesuit and Protestant missionaries in Africa belonged to their time. For this very reason, the few recorded cases of collaboration and mutual appreciation, though more personal than institutional, and even though almost completely lost in an ocean of suspicion and negative comment, should probably be accorded preferential weighting in any analysis of Christian denominational encounters in Africa.

69 Marshall, Christian Missions, 337.

70 Véronique Wakerley, trans., Journeys beyond Gubulawayo to the Gaza, Tonga and Lozi: Letters of the Jesuits' Zambesi Mission, 1880-1883, ed. R.S. Roberts (Harare: Weaver Press, 2009), 96-97.

71 Noble, Redemption of Africa, 409.

72 Ibid., 393 .

73 Ibid., 381. 


\section{Bibliography}

Barthélemy, Marcus. “During the Matabele Wars.” Zambesi Mission Record 1 no. 1 (1898): 19-21.

Baur, John. 2000 Years of Christianity in Africa: An African Church History. 2nd ed. Nairobi: Paulines Publications Africa, 2009 [1994].

Beckingham, C.F. [Charles Fraser], and G.W.B. [George Wynn Brereton] Huntingford. "Introduction." In Some Records of Ethiopia, 1593-1646: Being Extracts from The History of High Ethiopia or Abassia by Manoel de Almeida Together with Bahrey's History of the Galla, translated and edited by C.F. [Charles Fraser] Beckingham, and G.W.B. [George Wynn Brereton] Huntingford, xxi-xlix. Aldershot and Burlington: Ashgate, 1954 .

Bick, Charles. “The Missions of Kaffraria." Zambesi Mission Record 1, no. 1 (1898): 27-34. Carmody, Brendan P. Conversion and Jesuit Schooling in Zambia. Leiden: Brill, 1992.

Chadwick, Hubert. Life of the Venerable Gonçalo da Silveira of the Society of Jesus: Pioneer Missionary and Proto-martyr of South Africa. London: Manresa Press, 1910.

Coulbeaux, Jean Baptiste. Histoire politique et religieuse de l'Abyssinie depuis les temps les plus reculés jusqu'à l'avènement de Ménélick II. 3 vols. Paris: Geuthner, 1928.

Creary, Nicholas M. Domesticating a Religious Import: The Jesuits and the Inculturation of the Catholic Church in Zimbabwe, 1879-1980. New York: Fordham University Press, 2011.

Gelfand, Michael, ed. Gubulawayo and Beyond: Letters and Journals of the early Jesuit Missions to Zambesia (1879-1887). London: Geoffrey Chapman, 1968.

Guilday, Peter. "The Congregation de Propaganda Fide (1622-1922)." Catholic History Review 6, no. 4 (1921): 478-94.

Henkel, Reinhard. Christian Missions in Africa: A Social Geographical Study of the Impact of Their Activities in Zambia. Berlin: Dietrich Reimer Verlag, 1989.

Hole, Hugh Marshall. Lobengula. London: Philip Allan \& Co., 1929.

K. "On the Character of Jesuit Missionary Teaching." Church Missionary Intelligencer and Record (July 1886): 529-45.

Latukefu, Sione. "The Case of the Wesleyan Mission in Tonga." Journal de la Société des océanistes 25 no. 25 (1969): 95-112.

Lipschutz, Mark R., and R. Kent Rasmussen. Dictionary of African Historical Biography. 2nd ed. London: University of California Press, 1986.

Livingstone, David. David Livingstone and Cambridge: A Record of Three Meetings in the Senate House. London: Universities Mission to Central Africa, 1908.

Livingstone, David. Missionary Travels and Researches in South Africa:Including a Sketch of Sixteen Years' Residence in the Interior of Africa. London: Ward, Lock \& Co., 1857.

Livingstone, David, and Charles Livingstone. Narrative of an Expedition to the Zambesi and Its Tributaries; And of the Discovery of the Lakes Shirwa and Nyassa, 1858-1864. London: John Murray, 1865. 
Lobo, Jerome. A Voyage to Abyssinia. Translated by Samuel Johnson. London: Elliot and Kay, 1789 .

MacCulloch, Diarmaid. A History of Christianity: The First Three Thousand Years. London: Penguin Books, 2009.

Malta Protestant College. Journal of a Deputation Sent to the East by the Committee of the Malta Protestant College in 1849 [...]. 2 vols. London: James Nisbet and Co., 1854. Markowitz, Marvin D. “The Missions and Political Development in the Congo." Africa: Journal of the International African Institute 40, no. 3 (1970): 234-47.

Marshall, Thomas William. Christian Missions: Their Agents, their Method, and their Results. 3 vols. London and Brussels: Burns and Lambert and H. Goemaere, 1862.

Mkenda, Festo. "Jesuits and Africa." Oxford Handbooks Online; available online at http:// www.oxfordhandbooks.com/view/10.1093/oxfordhb/9780199935420.001.00o1/ oxfordhb-9780199935420-e-56 (accessed June 24, 2017).

Morrison, J.H. [James Horne]. The Missionary Heroes of Africa. New York: George H. Doran Company, 1922.

Neill, Stephen. A History of Christian Missions. Harmondsworth: Penguin, 1964.

Ngetich, Elias Kiptoo. "Catholic Counter-Reformation: A History of the Jesuits' Mission to Ethiopia 1557-1635." Studia historiae ecclesiasticae 42, no. 2 (2016): 104-15.

Noble, Frederic Perry. The Redemption of Africa: A Story of Civilization. 2 vols. New York: Young People's Missionary Movement, 1899.

O'Malley, John W. A History of the Popes: From Peter to the Present. Lanham, MD: Sheed \& Ward, 2011 [2010].

Pakenham, Thomas. The Scramble for Africa 1876-1912. London: Weidenfeld and Nicolson, 1992.

Porter, Andrew. Religion versus Empire? British Protestant Missionaries and Overseas Expansion, 1700-1914. Manchester and New York: Manchester University Press, 2004.

Schapera, Isaac, ed. David Livingstone: Family Letters 1841-1856, 2 vols. London: Chatto \& Windus, 1959.

Sykes, Robert. "Protestant Missionary Activity in South and Central Africa." Zambesi Mission Record 1, no. 1 (1898): 11-15.

Tachard, Guy. A Relation of the Voyage to Siam: Performed by Six Jesuits Sent by the French King, to the Indies and China in the Year 1685. Bangkok: White Lotus Press, 1999 [1688].

Thibaut, Emile. Les fermes-chapelles: A propos d'un débat récent. Brussels: Goemaere, 1911.

Thornton, John K. "Afro-Christian Syncretism in the Kingdom of Kongo." Journal of African History 54, no. 1 (2013): 53-77.

Thornton, John K. "Conquest and Theology: The Jesuits in Angola, 1548-1650." Journal of Jesuit Studies 1 (2014): 245-59. 
Wakerley, Véronique, trans. Journeys beyond Gubulawayo to the Gaza, Tonga and Lozi: Letters of the Jesuits' Zambesi Mission, 1880-1883. Edited by R.S. Roberts. Harare: Weaver Press, 2009.

Werner, Ronald, William Anderson, and Andrew Wheeler. Day of Devastation, Day of Contentment: The History of the Sudanese Church across 2000 Years. Nairobi: Paulines Publications Africa, 2000.

Wilson, John. The Lands of the Bible. 2 vols. Edinburgh: William Whyte \& Co., 1847. 
Robert Aleksander Maryks and Festo Mkenda, S.J. - 978-90-04-34715-1 Downloaded from Brill.come4/26/2023 02:06:52PM via free access 


\section{PART 2}

\section{Memories of Earlier Missions}


Robert Aleksander Maryks and Festo Mkenda, S.J. - 978-90-04-34715-1 Downloaded from Brill.come4/26/2023 02:06:52PM via free access 


\title{
Following in Jesuit Footsteps: British Expeditions to Ethiopia in the Early Victorian Era
}

\author{
Jesse Sargent
}

This volume explores the issue of encounters. When thinking about an encounter, the first image that comes to mind is a face-to-face meeting between two individuals: a chance meeting, a sudden turn around a bend that lets one know there is an "other" staring back at you. At times, an encounter plays out over years, many microcosms of confronting this or that other, rubbing up against what is with you but not you. From this rubbing, a bit of friction, a few sparks are born, which may either light the way in a descending darkness, or ignite an inferno that consumes the world.

This "rubbing up against" another drives much of human interaction and human history. World history is replete with tales of adventurers and romantics, climbing aboard this ship or that caravan, carrying themselves off to faraway lands, speaking with a king or a magi of this or that distant nation. Missionaries and explorers fanned out across nations and civilizations, generating meetings and instructive experiences. Encounters between Jesuits and Protestants bring to mind tales of individual confrontation with other individuals, a handshake or a violent strike exchanged in person, a Jesuit priest staring across the salt waters of Nagasaki Harbor toward the island of Dejima, where willful heretics expanded their trades at the expense of the Jesuits' own influence. Yet so many encounters lack this drama or personal touch. So many encounters remain of the second or third order, hearsay or rumor of this or that "other," far away beyond the horizon, but most definitely existing; an encounter with the idea of an encounter.

Historians are left with records of momentous meetings, a window into what came before, in which we can find an encounter of long past. Such inscribed experiences spread out along networks, books, letters, and maps, producing an intellectual echo of the encounter that moves far beyond the space and time of its experiential roots. Thanks to the technology of writing, it has been possible for so many then and now to engage in encounters across ages and settings that they do not share, feeling perhaps, through this echo, a sense of the "rubbing up" of the two exchanging glances on the page. 
The influences or consequences of these secondary-order encounters can often be detected more widely and subtly than any other first-order experience of a handshake, and it is this type of encounter to which the following analysis turns. Under the conceptual framework of encounters between Jesuits and Protestants in Africa, this chapter examines an "encounter" that played out over the pages of many books and manuals, bridging a span of more than two centuries, between Jesuit missionaries sent throughout the world in the wake of the Renaissance and Protestant Britons of the Victorian age poised on the cusp of a new empire upon which the sun would never set. Although the literary encounter could happen only from the later perspective of the British, each was informed by their shared experience of encounter with the lands of Ethiopia. Drawn by old mythologies and ancient histories of Abyssinia, Jesuit and Protestant alike toured the lands, treated with lords, and observed the people. In their efforts to open the pathways inland, the British drew consciously on the historical examples of their Catholic forebears, their records and inscribed memories, an intimate encounter with Jesuit writings from a Society that had almost completely disappeared under decades of suppression. This space will be used to explore and analyze the literary encounter of British travelers with their Jesuit predecessors, "rubbing up against" an encounter that they both shared, and the historical and intellectual reverberations that subsequently colored contemporary interpretations of their histories. The chapter proceeds by revisiting the narrative of the original Jesuit missionaries in Ethiopia and progresses to the entrance and growth of British influence. In particular, the chapter highlights the perspectives through which these Victorian authors approached the tales of their Catholic predecessors. The chapter will then reflect on the character of this "rubbing" between Jesuits and Protestants, and most importantly, the second-order effects of this historical encounter.

\section{Lands of Prester John and Early Modern Jesuit Visitors}

A detailed history of the lands south of the Egyptian Nile and west of the long Red Sea coasts is beyond the scope of the brief discussion here. Suffice to say, for many long centuries, the intercourse between the highlands of interior northeastern Africa and the Arabian Peninsula developed and sustained great waves of trade and exchange of "civilization." The activity of these ancient populations established regular flows of various commodities into lands that suffered from their lack. The development of Middle Eastern agricultural techniques meant that the Kingdom of Da'amat, situated at Yeha in Tigray 
(now northwestern Ethiopia), could exchange raw products such as ivory, gold, tortoiseshell, and slaves for finished goods of cloth, tools, and worked metals. ${ }^{1}$ The importation of South Arabian customs and forms of political organization birthed the major state of Axum, from the city of the same name, which grew from the ruins of Da'amat to cover most of the western Red Sea coast south of Egypt and the associated upper highlands proceeding southwest from the sea's edge. This major political force came to dominate the area through its issuance of local currency and a regional military supremacy that resulted from its recorded conquests of southern Arabian rivals across the sea. ${ }^{2}$ Essentially, Axum augmented itself as a partner in the lively international trade of the Eastern Roman Empire's Mediterranean exchange, which stimulated the southward spread of an early Christian orthodoxy from Alexandria's ruling patriarch. ${ }^{3}$ The vicissitudes of domination, however, gradually reduced this state, first as a result of non-Christian south Arabian rebellions, and eventually, the loss of western coastal control after the seventh-century rise of Islam. These developments failed to penetrate far into the mountainous highlands, in which remnants of Axumite and particularly Coptic Christian traditions remained, sustaining a complex culture on the overland trade routes that fed on the links between coastal and interior northeastern Africa. The mountains of Lasta in these highlands birthed a renewed dynastic line in the Zagwes (c.900-1270), a period still poorly understood by historians, but furthermore such transformations drew the attention of crusading Europeans through a mutual meeting point at Antioch.

These violent interpenetrations of the Middle Ages therefore highlighted a renewed cultural diversification of the Levant and Arabia upon which the military sovereigns of these highlands consciously drew, establishing mythologies of a continuous Judeo-Christian tradition from the historico-cultural panoply of peoples and influences crisscrossing the region. The fourteenthcentury conquests of Amda Siyon (r.1314-44) established networks of imperial garrisons across previously independent fiefdoms of various nations while

1 Harold Markus, A History of Ethiopia (Berkeley: University of California Press, 1994), 3.

2 Richard Pankhurst, An Introduction to the Economic History of Ethiopia from Early Times to 1800 (London: Lalibela House, 1961), 44.

3 Church tradition highlights the shipwreck of two Syrian boys, Aedesius (fl. early fourth century) and Frumentius (d.383), who became ambassadors and bishops during the early Christian internationalism of the fourth century CE. Political and theological exiles flowed along these newly established links into the relatively wanting societies of the highlands to become cultural elites. Marcus, History, 7-8. 
reestablishing a network of information and monitoring through a renewed relationship with the Egyptian Coptic Church. A presentation of cultural, theological, and "national" uniformity became the key to the power of fifteenth-century Zara Yaqob (1399-1468, r.1434-68), who intentionally staged his coronation as negusa negast (king of kings) in the highlands at Axum's ancient capital. Using Christianity as a convenient anti-Muslim ideology, Yaqob reconquered the western Red Sea coasts while establishing a permanent capital for his kingdom and reaching out to various non-Muslim powers across the Mediterranean world.

These were the conditions under which a post-Roman medieval Europe began to reestablish its knowledge of a non-Muslim, African kingdom nestled somewhere in the mountainous highlands west of the Red Sea. ${ }^{4}$ Yaqob had sent ambassadors to courts in Rome and a few ecclesiastical councils, while some European travelers had begun to filter into the country through connections in the Levant. This growing interaction was hampered significantly by the fact that most of the foreigners and skilled artisans that made their way into the highlands were not allowed to leave again, for reasons of both security and skilled labor shortages. Yet these hazy stories had piqued the interest of the Portuguese sovereigns, looking for a way to break the Venetian-Egyptian trading monopolies, as they began to work their way down the western coasts of Africa toward the Cape of Good Hope. Fifteenth-century legends of this "Prester John," a powerful, wealthy Christian lord who had been fighting successfully against the Ottomans, had reached through the peninsular heartlands of Italy and drawn the Portuguese into hopes of an alliance. ${ }^{5}$ When a letter from just such a sovereign arrived in the hands of an Armenian trader, Matthew, on the doorstep of King Manuel I of Portugal (1469-1521, r. 1495-1521) in 1509, it seemed that these legends had been proved as truth.

After the Portuguese takeover of Goa in 1510, the immediate importance of establishing an alliance with this mysterious kingdom waned somewhat. Yet in addition to the new Portuguese entrants into the Indian Ocean, the Ottoman defeat of Mamluk Egypt in 1517 had turned the Red Sea into an "Ottoman lake" and reinvigorated coastal Muslim communities. The Portuguese invaded and took over the northern port at Massawa, finally penetrating the highlands in

4 The Periplus of the Erythraean Sea makes mention of Axum during the survey of the shores during the first century $\mathrm{CE}$, and this seems to be one of the last serious historical recordings of the kingdom left to Western Europe before the late Middle Ages and Renaissance. See The Periplus of the Erythraean Sea, trans. G.W.B. [George Wynn Brereton] Huntingford (London: Hakluyt Society, 1980).

5 Elaine Sanceau, The Land of Prester John (New York: Knopf, 1994). 
$15^{20}$ with an embassy led by Father Francisco Álvares (c. 1465-1536). ${ }^{6}$ Sticking for the most part to their "blue water" strategy, the Portuguese efforts toward inland contact remained intermittent, and Lebna Dengel's (1501-40, r.1508-40) control of the highlands began to fall to the revitalized jihad of Zeila's Ahmad Gran (c.1506-43). This holy warlord brought ruin to the highland provinces until 1541, when the Portuguese had established enough strength in the Indian Ocean to land again at Massawa with four hundred musketeers. Gran's defeat in 1543 opened the period of direct intercourse with a Christian West that would define the story of the Jesuits there.

Founded in 1540, the Society of Jesus represented a Catholic revitalization movement based on a wave of "Counter-Reformation" missionization intended to restore the political and theological loyalties of protesting Christian nations. Note of this besieged "Christian" nation saved by the Portuguese was drawn under the same spirit, as even the Society's co-founder Ignatius of Loyola $\left(c .1491-155^{6}\right)$ is said to have fervently wished to missionize there. ${ }^{7}$ After the first Portuguese invasion, Álvares was supplanted by another Catholic who had accompanied the mission: João Bermudez (d.1570) was now recognized as the new abuna, the Christian patriarch, which cemented a new alliance between the emperor and Portugal and replaced the Coptic suzerainty of now Ottoman-occupied Egypt. This relationship was taken over by members of the Society, as ordered by the pope. Recalling the political machinations of late Renaissance Europe, where a Counter-Reformation Catholic Church still ran a juridical and spiritual empire of sorts, submitting to proper spiritual authority and rites was a confirmation of a certain symbolic mastery. And this is what the first Jesuits, João Nunes Barreto $(c .1510-62)$ and Andrés de Oviedo (1518-77), were sent to obtain from the newly allied sovereign in 1557 . While Barreto was invested as patriarch by the pope and he managed to arrive in Goa, it was Oviedo who first entered Ethiopia and began negotiations with the emperor about a national conversion to Catholicism. ${ }^{8}$ Knowing well that this would alienate him from the very people he was trying to win over in a precarious wartime situation, Emperor Menas (d.1563, r.1559-63), with whom Oviedo

6 Francisco Álvares, Narrative of the Portuguese Embassy to Abyssinia during the Years 1520-1527, trans. Henry Edward John Stanley (London: Hakluyt Society, 1881). The death date cannot be fixed, but occurred between 1536 and 1541. The popularity of his narrative as the first reliable and direct observations on a declining Ethiopia led to its translation and distribution by the Hakluyt Society during the late Victorian period.

7 Pankhurst, Introduction, 81.

8 Michael Russell, Nubia and Abyssinia: Comprehending Their Civil History, Antiquities, Arts, Religion, Literature, and Natural History (Edinburgh: Oliver \& Boyd, 1833), 134-37. 
treated, instead sent the Jesuit to a small village near Axum, keeping his party under close guard as valuable diplomatic envoys (a typical ploy for European visitors or royal rivals in the complex history of the region). Oviedo renamed his prison village "Fremona" in the spirit of the first conversion of that country, effected, according to tradition, by the ancient Frumentius himself.

The Jesuits essentially became the link by which Portuguese India, the crown, and the papacy maintained their tenuous connection to the Prester's realm. While the Ottoman presence in south Arabia and the Indian Ocean had been on the wane as the empire concentrated on its conflicts in the Balkans and Safavid Mesopotamia, new European entrants into the Indian Ocean threatened the Portuguese monopoly on the seas, while the "Galla" (Oromo) were among the revitalized migrations of African peoples ("pagans") to the south and west of the highlands. The second half of the sixteenth century was spotted with failed attempts to augment the aging Jesuit presence in the highlands: in 1589, a mission was shipwrecked in the Red Sea with the Jesuits captured by Turkish authorities; another mission, in 1595, ended in a Jesuit's unfortunate decapitation in Massawa. ${ }^{9}$ Geographical knowledge of these highlands continued to be poor given the difficulties involved in sending information out of the country: "Ethiopia" as a locale was interpreted by Europeans to be immense, stretching far south into "pagan" lands as far as the Cape of Good Hope, and the sixteenth-century geographic literature bears out this seriously flawed characterization. The Jesuits' efforts to gain access to and information about the country eventually succeeded, however, in the figure of Pedro Páez (1564-1622), a Spanish Jesuit captured in the 1589 mission who learned Arabic during his captivity in Yemen before returning to Massawa in 1603 .

Páez spent nearly twenty years in Ethiopia, taking over the Jesuit enclave at Fremona and making inroads into the good graces of the negusa negast $\mathrm{Za}$ Dengel (d.1604, r.1603-4). He traveled the highlands extensively and recorded a great deal of geographical knowledge about the country's size and natural features, among many other things. In his History of Ethiopia, which remained unpublished and largely unavailable for nearly three centuries, Páez presents a summation of all Jesuit knowledge and history on the country until that point, including the Solomonic legends first popularized under the Zagwe, and the diplomatic history of the first Portuguese embassies and Oviedo's

9 Hervée Pennec, "Missionary Knowledge in Context: Geographical Knowledge of Ethiopia in Dialogue during the 16th and 17th Centuries," in African History: Written Culture in a Colonial Context, Vol II: Africa and the Americas 1500-190o, ed. Adrien Delmas and Nigel Penn (Boston: Brill, 2012), 75-96. 
original mission..$^{10}$ Yet for our current purposes, Páez's observations went far beyond those of his predecessors: he wrote chapters on the natural wildlife present in the highlands, the climate and biospheres, the rivers, lakes, and geographical features. He appears to have been fully aware of Ethiopia's religious diversity and the variety of "vassals" that were theoretically subject to the rule of the negusa negast. Páez himself served as the front-man for a new wave of Jesuit activity focused on the conversion of Ethiopians to Catholicism: Páez made inroads due to his knowledge of the language and customs, and perhaps his personal character, but once he was replaced after death, a more uncompromising character of the Society showed its face in his successors. When new Jesuit infiltrators finally made their way into the highlands again in the 1620 , they continued a great deal of the work that Páez had begun of describing and cataloging the features of the highland peoples and their cultures, as well as the region's geography. However, the newly assigned Catholic patriarch Afonso Mendes (1579-1659) also placed great pressure upon the negusa negast Susenyos $\left(157^{2-1632,}\right.$ r.16o6-32) to publicly profess the Catholic allegiance he had privately given to Páez, thereby earning the spurn of his own son and local political forces. The key context to recall is that during the period while the Jesuits were measuring, recording, negotiating with highland cultures, violent conflict continued to rock the entire area. During the previous century of intercourse, the area supposedly ruled by the negusa negast had shrunk by over half, and his ability to exercise power, outside of receiving the occasional tribute (perhaps alternatively seen as a taxation payment or religious donation) from various local warlords and chiefs (who could simultaneously be making some or many other similar payments), might be considered negligible. After Susenyos was overthrown by his son Fasilides (1603-67, r.1632-67), the Jesuits were again confined to Fremona while Fasilides established a new capital, named Gondar, far inland at Lake Tana; he eventually expelled the Jesuits completely, prohibiting their entry through Red Sea ports. Here ended the early modern Catholic dalliance with the highland powers connected with the negusa negast.

\section{Textual Transmissions to Enlightenment Europe and Britain}

The early seventeenth century marks a serious bookend in European understanding of and activity in the highlands of modern-day Ethiopia. While

10 Pedro Páez, Pedro Páez's History of Ethiopia, 1622, Vols. I-II, ed. Isabel Boavida, Hervé Pennec, and Manuel João Ramos (London: Hakluyt Society, 2011). 
Fasilides and other Gondarine negusa negasts engaged in new architectural, cultural, and educational pursuits, the court continued to exist in isolation. Domestic and international trade was completely dependent upon Muslims and other outsiders, including various near-eastern foreigners. Many Oromo had been politically incorporated into the empire during the previous century, but they had now become a major military and feudal force that had reduced the negusa negast and other Gondarine court members to titular puppets. By the end of the seventeenth century, the negusa negast had been forced to issue a decree legitimatizing the primacy of the local lords (ras) over court officials. Gondar became something like a captive royal compound, and an "Abyssinia" ruled by a "Solomonic dynasty" regressed into an insubstantial concept. By the mid-170os, the Age of Princes (Zamana Masafent) had ushered in a century of political anarchy and encouraged the mayhem of constant civil war. ${ }^{11}$

European concern for the highlands and a Christian Ethiopia also waned significantly as the theater of competition shifted toward the control of ocean trade routes and commercial entrepôts in Indian and Chinese waters. By the seventeenth century, England had emerged as a maritime power and began taking over various ports of Portuguese control in the East. Information on these exotic and faraway destinations was compiled and translated first by Richard Hakluyt (1553-1616) in his Principal Navigations, including a 1597 letter from Queen Elizabeth I (1533-1603, r.1558-1603) to the Ethiopian emperor asking for safe passage for her subjects, as well as a short abridgment of Álvarez's first narrative of the Portuguese, together with other information that identified "Aethiopians" as an ancient people on par with the Phoenicians or Carthaginians. ${ }^{12}$ The Society of Jesus itself continued its publications on Ethiopia during this period, but they were increasingly limited by the lack of reliable information on the interior and the struggles of an eighteenth-century Society headed toward the suppression. Mid-seventeenth-century Jesuits such as Jerónimo Lobo (1595-1678) and Balthazar Tellez (1596-1675) revised old Jesuit manuscripts on Ethiopia while speaking with one or two Ethiopian visitors to Rome where ambassador-monks still appeared on rare occasions. Tellez in particular revised the unpublished History of Ethiopia of Manoel de Almeida (1580-1646), itself based on the work of Páez, to publish his own História geral de Etiópia-a-alta (166o) in Portugal, including some evidence of intercourse

\footnotetext{
11 Marcus, History, 47.

12 Richard Hakluyt, The Principal Navigations, Voyages, Traffiques \& Discoveries of the English Nation, Made by Sea or Over-land to the Remote and Farthest Distant Quarters of the Earth at Any Time within the Compasse of These 1600 Years, Vols. I-X (Glasgow: James MacLehose and Sons, 1903).
} 
with English officials. ${ }^{13}$ Copies of the book were extremely rare, and it took over thirty-five years for an unabridged translation to appear in French in 1728.

In general, corresponding readers from Protestant nations like Britain continued to wrestle with an exceptionally strong anti-Catholic, anti-Jesuit regard for information on such works heading into a new polemical period..$^{14}$ By the eighteenth century, and though some information had been passed through a still-strong Portuguese-British alliance, Portuguese and Jesuit networks were under severe strain as their overseas trade monopolies collapsed. Therefore, it was from a German scholar, a patchwork nation with no colonial exploits just emerging from the horrors of the Thirty Years' War (1618-48), that balanced and reliable information on contemporary Ethiopia began to emerge. Hiob Ludolf (1624-1704), sometimes considered the modern father of European Ethiopian studies, worked throughout the second half of the seventeenth century to standardize much academic European knowledge about Ethiopia, especially its classical languages. In a 1649 visit to Rome, he chance encountered "Father Gregory" (Abba Gorgoryos, 1595-1658), one of four locally residing Ethiopian monks, with whom he was able to converse in Ge'ez (as Gregory knew no Latin and little Italian). ${ }^{15}$ As a result of their cooperation, Ludolf published extensively on Ethiopia's language, culture, and history, including several dictionaries and an exceptional, encyclopedic history that appeared in English in 1682. ${ }^{16}$ Ludolf's studies became the contemporary gold-standard for information on the hidden land of "Prester John."

While Ludolf composed his volumes in European cloisters, others began to consider using this growing collection of written information on Abyssinia

13 Jerónimo Lobo, The Itinerário of Jerónimo Lobo, trans. Donald M. Lockhart (London: Hakluyt Society, 1984), xxv. Lobo himself appeared to be in contact with the Royal Society of London according to a 1668 letter, in which he claims to have assisted Tellez in the volume's composition.

14 Johann Michael Wansleben, A Brief Account of the Rebellions and Bloodshed Occasioned by the Anti-Christian Practices of the Jesuits and Other Popish Emissaries in the Empire of Ethiopia (London: Jonathan Edwin, 1679) provides an excellent example of this openly hostile attitude.

15 Edward Ullendorff, The Ethiopians: An Introduction to the Country and People (London: Oxford University Press, 1965), 8.

16 Hiob Ludolf, A New History of Ethiopia, trans. J.P. Gent (London: Samuel Smith, 1682). The details contained are impressive: ethnographic and geographic data, politics and systems of governance, religious customs and affairs, their economy and social/cultural habits. The sub-chapter headings demonstrate that Ludolf himself remained hostile to the historical Jesuit activities; the Jesuit "errors," local "quarrels," and the rebellions provoked by "Jesuit power" and "Roman religion." 
to attempt personal visits themselves. At this early stage, independent efforts were extremely rare: for example, French physician Charles-Jacques Poncet $\left(1655^{-1706)}\right.$ was sent from his post as an apothecary in Cairo to Gondar upon diplomatic request, the first such visit in decades, to treat the leprosy of Negusa Negast Iyasu I (1654-1706, r.1682-1706) and his sons in 1699. Poncet produced a short volume describing his journey and experiences in $1704 .{ }^{17}$ More marked was the influx of written information on Ethiopia in English and consumed by a growing class of literate semi-intellectuals - after Ludolf, the English translation of Poncet's volume and another of Tellez were released in 1710 with growing numbers of printing collaborators. ${ }^{18}$ A major breakout of the Ethiopian story from Ludolf's scholarly world occurred in 1735: an English poet and playwright, Samuel Johnson (1709-84), translated an entirely new English copy of Lobo's travels from the French original of 1728. While the translation was rough and required some revisions of the original French, it was written in the colloquial style that characterized Johnson's other works and therefore met with much popularity. ${ }^{19}$ These travel logs of Jesuit missionaries exploring "Aethiopia" in a somewhat distant past therefore began "rubbing up" against a particular and novel social class being formed in Britain and networked with the rest of Europe under a new, more popularized, artistic, bourgeois framework. In this light, it is easy to understand the subsequent publication of Johnson's A History of Rasselas in 1759; this richly written (yet fictional) historical novella revolved around a "Prince of Abyssinia" named Rasselas and his "adventures" during a rebellious sojourn outside of his homeland. This romantic and fanciful tale became so popular that it was reissued multiple times until well into the nineteenth century.

17 William Foster, trans., The Red Sea and Adjacent Countries at the Close of the Seventeenth Century, as Described by Joseph Pitts, William Daniel, and Charles Jacques Poncet, trans. William Foster (London: Hakluyt Society, 1949). Previous to the Hakluyt Society's 1949 translation, it was first published in English in 1709, in London, translated from the original French produced by Poncet himself; La relation abrégée du Voyage que M. Charles Poncet, médecin françois, fit en Ethiopie en 1698, 1699 \& 1700.

18 Both were published/printed out of "St. Paul's Church-yard" in London: the significance of this site remains beyond this chapter but would likely be an interesting and noteworthy investigation.

19 Joachim Le Grand (1653-1733) described Lobo's narrative as "so curious and entertaining." It is this attitude, rather than that of the scholar Ludolf, which appears to have animated Johnson's work. Joachim Le Grand, A Voyage to Abyssinia, by Father Jerome Lobo, a Portuguese Missionary, Containing the History, Natural, Civil, and Ecclesiastical, of That Remote and Unfrequented Country, trans. Samuel Johnson (London: Elliot and Kay, 1789), 23. 
As the intellectual classes of Europe and particularly Britain began to expand and diversify with the progress of the Enlightenment, so too grew the confidence of a new "nation" to strike out into the world and extract some truth from these elegant mysteries. One of the first and bravest in the attempt was James Bruce of Kinnaird (1730-94). Bruce not only conceived of an ambitious plan to discover the source of the Nile but furthermore had the determination and material resources to realize it. The location of the river's source was a subject of great debate even among the Jesuit travelers of previous centuries, yet Bruce's choice of challenge was not in favor of a Catholic world-community; rather, he hoped to

have shewn to the world of what value the efforts of every individual of your Majesty's subjects may be; that numbers are not always necessary to the performance of great and brilliant actions, and that no difficulties or dangers are unsurmountable to a heart warm with affection and duty to his Sovereign $\left[\ldots . .{ }^{20}\right.$

In other words, Bruce conceived of himself as achieving some great feat, through his own capacities, despite the fact that many modern authors claim that Páez's surveys on the Nile's source are decidedly more accurate. Indeed, Bruce was essentially aiming to demonstrate the superiority of a rising Protestant, nationally conscious European nation contrasted against the sclerosis of Catholicism.

This self-aggrandizing attitude revealed itself in his appraisals of the previous generation of Jesuit missionaries and their writings. While demonstrating his familiarity with these narratives, Bruce's evaluations remain decidedly hostile and even insulting. He refers to the celebrated Lobo as "a grovelling, fanatic priest" who wrote "a heap of fables, and full of ignorance and presumption [...]." He forcefully questioned all the details of descriptive geography in Lobo's Historia and discounted the Jesuit's ability to understand cartography. Yet, notwithstanding this dismissive attitude, Bruce indeed blew open the doors to the nineteenth-century engagement with Ethiopia: he had successfully led an independent mission into the heart of the highlands, where he encountered the reigning negusa negast and the ras who controlled him in Gondar, Mikael Sehul (c.1691-1779). Through his own linguistic capabilities, Bruce was able to

20 Samuel Shaw, An Interesting Narrative of the Travels of James Bruce, Esq. into Abyssinia, to Discover the Sources of the Nile, Abridged from the Original Work (London: B.D. Symonds, 1800), 12. Of course, the "majesty" of the British "sovereign" does appear to mirror a religious devotion to God. 
interact with numerous locals to produce a five-volume narrative on his travels and Ethiopia in general, effectively rivaling those of previous Jesuits, and with more contemporary fame. With its fine drawings and detailed information, Bruce's volume brought to life the fired imaginations of bourgeois literates whom Johnson's adventure tales had already aroused. He reiterated the claim that Ethiopia was an ancient society like Egypt, ripe for exploration and study, and he displayed no lack of skill at self-promotion during his meetings with European sovereigns after his return. ${ }^{21}$ The five years of his travels, combined with the two he spent among the Ethiopian court, presented an exciting window into a living Abyssinia. While Ludolf had perfected the paper image, Bruce had shown it was real.

A powerful tide of energy followed the 1790 publication of Bruce's Travels. Bruce had originally been drawn into his work in Africa by doing coastal survey work for the British consul in Algiers, and this practical objective was clearly a preoccupation for a rising blue-water empire. By 1804, another nobleman, George Annesley (1770-1844), together with his secretary, Henry Salt (17801827), also succeeded in penetrating the Tigray highlands by way of the Red Sea and the ancient port of Massawa. ${ }^{22}$ When news of the mission's success reached London, the British government immediately sent out an official naval survey led by Salt in order to produce proper navigational charts and lead the king's representatives safely from Massawa into Tigray. Not only did they establish regular diplomatic contact with Wolde Selassie (c.1745-1816), newly reigning ras of Tigray, but Salt was also able to use his unparalleled artistic skills to produce paintings and maps far superior to those of Bruce. His 1814 volume A Voyage to Abyssinia outdoes Bruce in precision, presentation, and clarity. ${ }^{23}$ Yet Salt's written scholarship also had important implications in the "rubbing up" of the Jesuit histories with the contemporary events of a rising Victorian Britain. While confirming through those he met the truth of Bruce's impact and presence, Salt provides a strong, informed critique of Bruce's tendency to self-aggrandize his own achievements, and questions his quality as a reliable

21 For example, he prepared and presented a copy of the lost biblical book of Enoch (preserved in Ethiopia) to the king of France Louis XV (r.1715-74). The volume of his narrative itself was dedicated and presented to King George III (r.1760-1820) of Britain as well. Many of the manuscripts he brought back were delivered to and still remain in royal libraries. Ullendorff, Ethiopians, 13.

22 Paul Henze, Layers of Time: A History of Ethiopia (New York: St. Martin's Press, 2000), 109.

23 Henry Salt, $A$ Voyage to Abyssinia, and Travels into the Interior of That Country, Executed under the Orders of the British Government in the Years 1809 and 1810 (London: F.C. \& J. Rivington, 1814). 
information source at all. ${ }^{24} \mathrm{He}$ accuses Bruce of willfully deviating from the truth and misrepresenting Lobo and Páez in order to build his own heroic legend. ${ }^{25}$ In contrast, the moderate Salt praises Páez's "extra-ordinary abilities" and the extreme value of Jesuit works like those of Tellez, "undoubtedly the most valuable work now existing on Abyssinian affairs, and there are said to be only three copies of it in England." ${ }^{26}$ He regarded Tellez's travel accounts as the most accurate recordings of the Massawa route from the Red Sea to enter the highlands, which he himself had followed in entering the country rather than the overland Nile route of Bruce. ${ }^{27}$ His major criticism remains the Portuguese nationality of these "priests" and the lack of attention they gave to their own vassals, complaining that "their motive proceeded rather from an idle vanity of extending the list of their proselytes, than from any actual desire to benefit the individuals whom they pretended to convert." ${ }^{28}$ Salt shows his own character in these accusations, highlighted in his volume's dedication, which, like Bruce, he gives to the British crown; unlike Bruce, who sought to promote his individual worth, Salt almost sounds like a missionary himself:

Should [this volume] succeed in attracting your notice to the present forlorn and distracted state of Abyssinia, so far as to induce your Royal Highness to promote the welfare of that country, by the introduction of useful arts together with a judicious advancement of the true tenets of the Christian Religion among its inhabitants, I shall feel that my exertions in this cause have not been in vain $[\ldots] .^{29}$

This notion of promoting the "welfare" of Abyssinia through "useful arts" and the "Christian religion" became the founding spirit for the Victorian era's interactions with the Ethiopian highlands. Indeed, the writings of the Jesuits described for these British visitors what Ethiopia "once was" and could be again. In order to realize these goals, much knowledge of the country was again necessary, as greater numbers of increasingly educated British citizens began trying to find their way into the country.

\footnotetext{
$24 \quad$ Ibid., 334, 338.

25 Ibid., 341. Despite this, Salt proves himself to be a very balanced and thoughtful man regarding Bruce's accomplishments: "I am perfectly aware how much Mr. Bruce has accomplished; and no man can any more truly admire his courage, his perseverance, his sagacity, or his genius than myself $[\ldots]$; ; 344 .

26 Ibid., $480-81$ (see note).

27 Ibid., 202-3.

28 Ibid., 65 .

29 Ibid., iii.
} 


\section{Victorian Missionaries, Scientists, and the Reappraisal of the Jesuit Legacy}

The continued decline of the Ottoman Empire during the late eighteenth century had stimulated the emergence of Muhammad Ali Pasha (1769-1849), a commander in the Ottoman army who seized power in Egypt and attempted to form his own independent dynasty after Napoleon's invasions in the early nineteenth century. Muhammad Ali realized his independence rested upon both his economic health and military puissance, and he accordingly developed strong relationships with the trade consulates of European powers who grudgingly accepted the wane of Ottoman influence. As Ali's armies began solidifying their control of the southern provinces, travelers searching for Salt's Abyssinia began to follow in their wake. The 1822 journal of George Waddington (1793-1869) represents an account of one such early journey. Waddington was a reverend investigating regions of Orthodox Christianity, and after receiving assistance from the British consul in Egypt and other local allies, he proceeded to explore well south along the Nile through Nubia to Me'rawe (Meroë) for the first time since Bruce. ${ }^{30}$ His mistaken belief that he had reached the ancient capital of Ethiopia at Meroë demonstrated these new entrants' poor understanding of the region.

Waddington was not an outlier in the early nineteenth-century British milieu, as the sentiments expressed by Salt seemed to animate much activity in civil society. A growing evangelical revival spurred the foundation of new missionary organizations like the Baptist Missionary Society (BMS) and the London Missionary Society (LMS ). Especially important was the Church Missionary Society (CMS), founded in 1799 and renamed in 1812, which promoted British evangelical activity in the overseas spaces they were coming to dominate in Africa, India, and other parts of the world. In 1830, the CMs supported a multinational missionary party headed by Swiss-born Samuel Gobat (1799-1879) to investigate the conditions in Ethiopia and provide the spiritual and material instruction for which Salt had pined. ${ }^{31}$ Gobat became a central figure in Ethiopia, the first European to visit Gondar since Bruce. The journal of his three-year residence in the city provides numerous details on Abyssinia and in particular the theological discussions in which he engaged with the local priesthood while his missionary party translated scripture into Amharic for distribution. He appeared at all times to make great efforts to integrate himself 
into a living Ethiopia, conforming to local virtues. But he expressly desired to find the best means of diffusing the word of God, "rendering himself useful to this miserable people, plunged into the depths of superstition and error." ${ }^{32} \mathrm{His}$ observations serve to confirm the absence of decisive information on Abyssinia's current conditions: Gobat could only guess at the total population, though he was able to identify the five major princes currently embroiled in a struggle for power, calling them all "brothers in Christ." 33

Gobat's observations indicate the social climate underpinning the rapid increase in Protestant missionary work during the following decades. He identifies the Jesuits as definite "pioneers" for Christ, distinguished from the earlier Portuguese period. The way he characterized the Jesuit relationships with Abyssinian figures is revealing, however: Oviedo was too bold and demanding, altogether "unbecoming of his condition or errand"; and even Salt's more positive image of Páez was tarnished in Gobat's eyes-his close work with Za Dengel was simply the result of his position as a Romish spy, trying to use religious "sophistry" to gain temporal power in the country. ${ }^{34}$ Gobat instead paints the Ethiopian emperors as equals of the Jesuits: Gelawdewos ("Claudius," 1521-59, r.1540-59) had equal theological knowledge to Oviedo, and could best the Jesuit in both discussions and writings. The ejection of the Jesuits was therefore reflected in the natural desire of the people to defend "the worship of their fathers" and stop the "demolition of the throne, the subversion of our religion." 35 This description seems to intentionally express the independent anti-Catholic character of Christian Abyssinia, while raising the profile of their legitimate "Christian" knowledge. Gobat's regret was that the great zeal and education of the Jesuits was improperly used in "propagating the errors of popery," while he himself advised that future missionaries should learn from this history. ${ }^{36}$

Gobat's perspectives on this relationship set the stage for the increased missionary engagement with Ethiopia that followed in his wake. One of his companions, Karl W. Isenberg (1806-64), stayed on in Tigray after Gobat's

32 Samuel Gobat, Three Years' Residence in Abyssinia (New York: M.W. Dodd, 1850), 113.

33 Ibid., 31, 35-36. This religious viewpoint echoed the spirit of the times, a Christian revival and missionary drive shared across the Anglophone sphere and characterized in the United States as the Second Great Awakening.

34 Ibid., 66-69, 76. Specifically, he accuses the Jesuits of dreaming of using military power to subdue the Ethiopian court.

35 Ibid., 85,95 .

36 Ibid., 108, 114. "Both the philanthropist and the Christian must grieve that so much time has been wasted, so much labor lost, so much fortitude and Christian heroism spent to no valuable purpose, and so many lives sacrificed in carrying forward an undertaking so entirely at variance with the benign and heavenly spirit of the Gospel." 
departure to become bishop of Jerusalem, and he was joined in 1837 by Johann Ludwig Krapf (1810-81). Both of these German missionaries attempted to continue the work of Gobat's Christian "charity" without falling into the Jesuit "trap" of which he had warned. But this proved exceedingly difficult: the two missionaries were expelled from Tigray in 1838 after conflicts with Abyssinian churchmen, which Krapf conveniently blamed on the simultaneous meddling of the Church of Rome. ${ }^{37}$ Making their way from Zeila to Shoa, a semi-independent Christian kingdom in southern Abyssinia known only poorly to Gobat, Isenberg and Krapf established themselves and recommitted to their simple charity work "diffus[ing] Scriptural light in a region of darkness," in contrast with, they claimed, a Catholic vehemence that locals "still remember" with violent dissatisfaction. The missionaries' written works, echoing the high scholarship of Ludolf, filled British presses with information on Ethiopia while they also continued to translate Bibles and other works for local distribution. ${ }^{38}$ Yet the difficulties of their enterprise weighed heavily on them as complaints increased about the lack of Amharic competency among most of the populace, the politico-theological controversies that divided Abyssinia internally, and the hard realization that much of local "Christianity" remained a syncretic "mixture of Jew, Muslim, Christian, and Pagan" rites (a distasteful diversity that the missionaries associated with the corruption of Islam). ${ }^{39}$

It must be remembered that these missionaries and the CMS existed in a growing bourgeois network of information cast across Europe and linked together through universities eager to study these new details of the living world. It was therefore not easy to separate the "pure" Christian motivations professed by Gobat from Enlightenment science and the application of Salt's "useful arts." Reverend Michael Russell (1781-1848), who was studying at the University of Edinburgh, published a volume entitled Ethiopia above Egypt in 1833, which surveyed the increasing number of written accounts on Abyssinia and

37 Charles William Isenberg, Journals of Rev. Messrs. Isenberg and Krapf, Missionaries of the Church Missionary Society, Detailing Their Proceedings in the Kingdom of Shoa, and Journeys to Other Parts of Abyssinia, in the Years 1839, 1840, 1841, and 1842 (London: Seeley, 1843), vi.

38 Ibid., xi. For example, Isenberg produced spelling books, catechisms, grammar dictionaries, church histories and general histories of Abyssinia, all in Amharic, while additionally compiling vocabularies of the Dengali language, and the Galla (Oromo) language, including a translation of St. Matthew's Gospel. These voluminous efforts cannot help but recall the copious works of Jesuits from an earlier period.

39 Ibid., 107-10, 118. They recommended that Bibles and other writings therefore be written in "Aethiopic" (not Amharic) for distribution among the local populace. 
its history. ${ }^{40}$ His work echoes the aforementioned characterizations of Oviedo as a zealous and self-aggrandizing political operative, while reserving a more positive outlook for Páez. The reasoning behind his opinions highlights the strengthening "scientific" perspectives that would begin to follow the new generation of Victorian missionary pioneers: Abyssinia was again re-centered in a field of ancient societies, Carthage, Egypt, and Palestine. Much of Russell's volume is thus concerned with non-religious information: the geography, civil history, architecture, geology, and zoology of Abyssinia. He places a great deal of emphasis on the access provided to Abyssinia through the military campaigns of Pasha Ali, and his personal reliance on accompanying members of the British army for drawings and measurements of archaeological sites. ${ }^{41}$ From his comfortable university armchair, Reverend Russell demonstrated that he was different from Gobat, the fervent, intrepid, self-sacrificing missionary thinking only of Bible distribution; instead, the religious, "civilizing" question could be influenced by both spiritual and material techniques (echoing Salt), in necessary cooperation with legal and military force.

As the scientific revolution gained steam in Victorian Britain, the "superior talents" of the British in these areas of science began to manifest under the public control of the army and navy. Upon hearing of the new route to southern Abyssinia traversed by Isenberg and Krapf, the government immediately sent a mission to follow in order to establish secure diplomatic contact with Sahle Selassie (c.1795-1847, r.1813-47), negus of Shoa. Under Major William Cornwallis Harris (1807-48) from the Bombay Engineer Corps, the mission managed to penetrate the kingdom by the same route as the missionaries but with new scientific and human resources at its command ${ }^{42}$ These new capabilities were reflected in its mission:

Efforts zealously directed under the auspices of a liberal government, toward the establishment of a more intimate connection with a Christian

\footnotetext{
40 Russell, Nubia and Abyssinia. We should note, in comparison with the Jesuits (e.g., Alessandro Valignano [1539-1606]), that Russell was both a reverend and a lawyer. Ibid., 9-10. He further explicitly emphasized the good prospects for the cMs work in Ethiopia as a result of these military interventions.

42 William Cornwallis Harris, The Highlands of Aethiopia (London: Longman, Brown, Green and Longmans, 1844), v. The embassy also included members of the army, navy, Bombay medical service, a natural historian, an artist, a professional surveyor, an apothecary, a carpenter, and a smith. The appearance of various "scientists" is key; the natural historian Dr. J.R. Roth studied Palestine, echoing Russell. Furthermore, their writings were now also protected internationally by newly issued copyright laws extending from an act of the British Parliament. Ibid., 3 .
} 
people, who know even less of the world than the world knows of them - toward the extension of the bounds of geographical and scientific knowledge, the advancement of the best interests of commerce, and the melioration of the lot of some of the less favored portions of the human race. $^{43}$

Harris proclaimed his debt to Krapf, whom the embassy met upon arrival, for his services in the government's favor, particularly his mastery of languages and for acting as intermediary interpreter for the embassy. Furthermore, he recorded his "personal sense of obligation to the active and pious Missionary of the Church of England." In addition, the geographical information contained in the unpublished recordings of Isenberg's and Krapf's endeavors was so striking and extensive that many of these secular scientists rushed to assist them in consuming the information and publishing usable maps for the territory. ${ }^{44}$ Rather than simply saving immortal souls, a geopolitical objective had emerged in British assistance to this Christian nation, not so different from the earlier Portuguese: the attraction of a native partner in "civilizing" Africa. ${ }^{45}$ Thus the missionary and geographer began to cooperate intensely, based upon the direct observations of the land and experiences with the people held by the former. After another expulsion of missionaries from Ethiopia in 1842, Krapf's attitudes seemed to have hardened along similar lines as his new allies. Writing more than a decade later, in 1855, while linking himself with the new southeastern African missions of David Livingstone (1813-73), Krapf lays bare the frustrations with which his Abyssinian life had left him:

My calling, in which through all perils I have been so mercifully preserved and upheld, enables me to set forth in their true light the moral misery and degradation to which the heathen nations of East Africa have fallen, and to point out the various routes by which these benighted populations may be approached, and the means for their elevation to

43 Ibid., 7 .

44 Isenberg, Journals, xvi. He claims his information was the basis of James Macqueen's (1778-1870) Geographical Survey of Africa (London: B. Fellowes, 1840), which Harris utilizes extensively himself.

45 We can find in Macqueen's volume an explicit formulation of Harris's implicit remarks: "Abyssinia has been since early times a Christian country [...]; they are surrounded on all sides by tribes of the most savage character [...]; a connection with a strong civilized European power may even yet make that state the means of spreading knowledge and civilization through the hitherto most unknown and most impenetrable portion of Central Africa." The primary sources for his discussion are quoted as Bruce and the "Portuguese missionaries." Macqueen, Survey, 239. 
Christian truth and Christian civilization be conveyed to them [...]; in the memorable words of Dr. Livingstone, "the end of the geographical feat is but the commencement of missionary operations." 46

The isolation and difficulties Krapf had faced brought him to the conclusion that regular, stable access was the key to Christianizing Ethiopia, which could only be effected by political and military stability. The vicissitudes of various local conflicts and petty rivalries had destroyed the missionary's work twice, forcing him from the country, which meant standardization (and therefore stabilization) of the entryways was now the priority. This difficult lesson echoed the experiences of the earlier Jesuits themselves of course.

Krapf's observations dovetailed with the new scientific spirit of his times. Russell's volume, which focused on natural sciences and history, appealed to growing secular-scientific communities, who shared the CMs interest in active engagement across the world, but increasingly became organized under the crown. For example, the Geographical Society of London had been founded in 1830 and upgraded to the Royal Geographical Society (RGS) in 1859 by Queen Victoria (1819-1901, r.1837-1901). The efforts of the RGS were directed at accurately mapping the plethora of territories that were increasingly subject to British influence, such as those in Africa and India. Another, the Hakluyt Society, was founded in association with the British Library in 1846 as a learned society dedicated to translating historical documentation on such territories, replacing the independent work of earlier scholars like Johnson. ${ }^{47}$ Mapping, descriptions, and the translation of historical information were now professional trades executed through organizations with highly educated "scientist" members. These upper-class participants of various learned societies were often intertwined, and their viewpoints increasingly came to influence the policy of the British government.

Such scientific innovations, in combination with the previous southward military advances of Muhammad Ali, had significantly eased the difficulties for independent travelers in accessing these unstable routes into Abyssinia. One such adventurer, Mansfield Parkyns (1823-94), published an extensive volume on his travels, dedicated to future prime minister Lord Palmerston, Henry

46 J. Ludwig Krapf, Travels, Researches, and Missionary Labors during an Eighteen Years' Residence in Eastern Africa (London: Trubner and Co., 1860), xlv.

47 For example, see the work of a Portuguese survey of East African and Indian coasts, translated in 1866. Duarte Barbosa, A Description of the Coasts of East Africa and Malabar in the Beginning of the Sixteenth Century, trans. Henry Stanley (London: Hakluyt Society, 1866). 
John Temple (1784-1865, in office $1855^{-58}$ and $\left.1859-65\right) .{ }^{48}$ Parkyns, like Bruce, represented the non-missionary who traveled simply for his own interest, and his position among this Victorian upper class had given him the intellectual tools to succeed. Like the sedentary Russell, the recordings of this active traveler show the growing scientific discourses common to mid-century Britain, writing on Abyssinian botany, ornithology, medicine, zoology, and biology ${ }^{49}$ Entering Tigray through Massawa in disguise in 1850, Parkyns's narrative represents an important counterpoint to those of the missionaries. Indeed, Parkyns remains rather hostile to them, suggesting that religion could prevent believers from accrediting truth. ${ }^{50} \mathrm{He}$ is similarly critical of the missionaries' activities he observed in Abyssinia, who mocked traditional culture, endlessly distributed Bibles that none could read, and preached boldly in constant disputation with Abyssinian clergy. ${ }^{51}$ Parkyns had personally observed an Anglo-German missionary's ejection from the kingdom, and complained that such "bold preaching" should be tempered "with much judgment" and tact; the name of Samuel Gobat was still well loved in Abyssinia due to his embodiment of these traits. Even if religious conversion was the desired aim, Parkyns emphasized that a missionary should adopt Abyssinian life-ways, remain silent on religious questions, and begin openly displaying and educating Abyssinians in various trade skills. Although his volume contains virtually nothing on the Jesuits themselves, his recommended approach echoes Russell's unique valorization of Páez in particular. ${ }^{52}$

48 Mansfield Parkyns, Life in Abyssinia: Being Notes Collected during Three Years' Residence and Travels in That Country, Vols. I-III (New York: D. Appleton Company, 1854), 3. He credits British efforts for his safe passage in Africa: "Spread the great protection of the British Crown and power over the solitary and helpless traveler among nations whose deficient civilization permits them to respect only what they fear."

49 Ibid., 17, 196.

$50 \quad$ Ibid., 14.

51 Ibid., 134, 137-40.

$5^{2}$ Indeed, his description echoes eerily the accommodative efforts of certain Jesuits: "Teach them trades, opening schools (under native masters) [...] inducing young men of influence $[\ldots]$ to visit foreign lands $[\ldots]$ [then you] settle among them [...] [getting] into their ways and feelings $[\ldots]$ make friends with all the great men of the country $[\ldots]$ especially with the priests [...]." The negative aspects of Jesuit missionization are also echoed: "Conscientious readers may condemn this somewhat deceitful way of dealing with them, and I should be the last to recommend it, if any other would be likely to succeed, but experience has taught me that the natives, being excessively ignorant, may be considered in a state of intellectual infancy $[\ldots]$ you are obliged to sweeten the edge of a cup for a sick child [...]"; ibid., 142. 
The critique of this rising secular perspective made itself felt in the increasing cooperation between missionaries like Krapf and the RGS. Krapf's 1860 journal publication contains additional chapters and appendices by Ernst Georg Ravenstein (1834-1913) from the RGS, which reappraise much of the information in Krapf's earlier journals in order to standardize distances, longitudes, and latitudes, in addition to adding tables of commercial imports and exports, comparing European nations' trade with Africa. ${ }^{53}$ Two decades after Krapf and Isenberg's original publication, it was absolutely clear that now missionary and geographer were working as partners in their Africa policy. They additionally found allies in each other due to their mutual opposition to the Catholic French competition for influence in the region.

On the other hand, through their work with missionaries like Krapf and Livingstone, it is obvious that the secular-scientists who filled the ranks of royal societies, the government, and the military had gained a distinct appreciation for the detailed accounts contained in missionary reports from decades past. In particular, the concerns of exercising power within Abyssinia came to the immediate fore in the final years of the 1860 , under pressure from a new native negusa negast known as Tewodros II (c.1818-68, r.1855-68). This warlord had come to power from his position as a desert bandit after an impressive array of military victories and deft political maneuverings in the provinces of northern Ethiopia, until he had gained enough strength and acceptance from the Abyssinian Church to proclaim himself emperor of Ethiopia in 1855 . His fascinating story cannot be set forth in these pages; suffice to say that he hoped to augment his growing empire against hostile Egyptian and Oromo forces, appealing to the British for technological assistance and training in similar fashion to previous emperors long before. ${ }^{54}$ When this assistance was not forthcoming, Tewodros imprisoned the British consul Charles Cameron (d.1870) and his party visiting the royal camp in an effort to extort a response from Queen Victoria. Instead, it unfortunately provoked a massive military expedition from Britain to free them.

The manifold preparations for this unique and unprecedented military expedition into the interior of Africa demonstrate the appreciation that Victorian

\footnotetext{
53 Krapf, Travels, xxv-xxxiv.

54 Clements Markham, secretary for the RGs, gives the most detailed and best description of the rise of the bandit-warlord Kasa, his transformation into Tewodros II, and the descent into conflict with the British in Clements R. Markham, A History of the Abyssinian Expedition (London: Macmillan and Co., 1869), 60-81. More up-to-date accounts that focus on the Ethiopian perspective can also be found as well: Bahru Zewde, A History of Modern Ethiopia 1855-1974 (London: James Currey, 1991), 27-42; Markus, History, 59-72.
} 
geographer-scientists had gained for the Jesuit missionaries and their works. After Queen Victoria's public announcement of the expedition in August 1867, geographical insights into the planning became paramount. By November, the RGS had produced an open paper and discussion reviewing all the available historical evidence to be marshaled in approaching Abyssinia. ${ }^{55}$ The early evidence from Jesuit writings figured strongly in the discussion: the Jesuits are identified as skilled linguists, reading old Abyssinian chronicles and collecting the early history of the region. The paper was generally less positive about the scientific skills of the Jesuits; however, the one exception to this was Páez, who was praised for "great tact and judgment," his ability to "influence minds," his "genius," and his technical skills, which even allowed him to save the emperor's life. ${ }^{56}$ The rebellion against the negusa negast Susenyos I was therefore the fault of local rebels attached to backwards traditions rather than "Romish" interference. The discussion ended with a short synopsis of the routes by which the Jesuits entered the country. A few weeks later in the same month, a published report to the British Parliament opened a much larger discussion on the practicalities of the expedition, including a much more detailed review of the geographical entrances taken by both Portuguese and Jesuits. ${ }^{57}$ The British were keen to model their expedition on the former 1541 Portuguese embassy, and they used Jesuit sources like the 1710 version of Lobo's Travels to pinpoint the geographic approach. The final 1869 narrative of the expedition's successful liberation of the captives and Tewodros's death by suicide consistently draws the parallel between the "heroic" Portuguese and contemporary British. ${ }^{58}$ Here, Páez was described as "the ablest European that has yet resided in Abyssinia" and the expedition's observed surroundings were constantly compared with the Jesuit descriptions of Lobo and Mendes. Even the commander Robert

55 Clements R. Markham, "The Portuguese Expeditions to Abyssinia in the Fifteenth, Sixteenth, and Seventeenth Centuries," Journal of the Royal Geographical Society of London 38 (1868): 1-12. It is clear that the British implicitly compare their own expedition with the earlier "expeditions" of the Portuguese and their "priests."

$5^{6}$ Ibid., 8-9. Perhaps Páez's only mistake was pointed out as encouraging the emperor to make a public affirmation of and conversion to the Roman Catholic faith.

57 A.C. [Anthony Charles] Cooke, Routes in Abyssinia (London: Harrison and Sons, 1867). "Presented to the House of Commons, in Pursuance of the Address Dated November 26, 1867." Printed in favor of Queen Victoria “Her Majesty's Stationery Office." Translations of many Jesuit letters into English are included in this chapter, in addition to laying out the various entrances: the classic route from Massawa, the 1588 route from Zeila, the 1595 beheading of a Jesuit entering Massawa, the 1620 and 1622 entrances at Suakin, and the 1625 entrance of Lobo by Amphilla Bay. Ibid., 27-30. 
Napier (1810-90) felt a powerful affinity with the Portuguese embassy while marching up the same mountain pass to Senafe and the Ethiopian interior. Although the British refused to leave a garrison in the country after their successful mission, they did transfer a massive weapons cache to Dejazmach Kassa $(1837-89)$ in Tigray, who eventually became the new negusa negast Yohannes IV (r.1871-89).${ }^{59}$ In this way, the sordid and frequently maligned legacy of the Portuguese Jesuits had now become synonymous with the ultimate triumph of Victorian Britain's "Christian civilization" poised at the edge of the Scramble for Africa and the slide into brutal colonialism.

\section{Consequences of the "Rubbing Up" of History}

The literary "encounter" here described between Portuguese Jesuits and British Protestants has been shown as a lively and complex point of historical confluence. The lands both knew as Abyssinia became the canvas upon which their experiences echoed across time in the pages of the books they had left behind; a shared "encounter" with a people known poorly in the annals of recorded history. Although their meeting flowed in the direction of time, it is clear that the legacy of each epoch was shaped and reshaped through the "rubbing up" of their common experiences. The first-order effects of their literary encounter could be observed in the writings and appraisals of the Victorians regarding their Jesuit predecessors, and it is clear that these opinions were heavily influenced by Victorian Britain's own political and experiential conditions. At first, the Jesuit experience of Ethiopia was known only darkly, through legends and romantic mysteries, but as the nation matured intellectually, so too did the engagement with the history of these pioneers. The breakout nationalism of Bruce and the anti-political orientation of Gobat's idealized Christian community meant that the Jesuit would remain the anti-hero figure in their literary encounters. The "anti-Romish" spirit of their writings reflects the anti-Catholic politics of eighteenth-century Europe, which ultimately contributed to the Society's suppression. For Gobat in particular, the "rubbing up" of these narratives highlights their stark differentiation, and his dream of a "pure" Christianity independent from the secular sword and, in fact, eschewing it. But both practical experience and the rise of a class of secular (or privatized-Christian)

59 For a more detailed account of this sovereign's reign than is possible here, see Zewde Gabre-Sellassie, Yohannes IV of Ethiopia: A Political Biography (Oxford: Clarendon Press, 1975); esp. 24-40 for the complicated political transformations (and obfuscated British aid) that brought him to power. 
intellectuals revealed the naïveté of Gobat's vision. Indeed, as Protestant missionaries experienced the scourge of religious rejection and persecution, a distinct appreciation for the secular hand and its "useful arts" grew up in ways not dissimilar to the Jesuits themselves. Rising imperial power and a scientific self-confidence had revitalized the national spirit that drove Bruce's investigations, and rather than receiving ridicule, missionary skills could be well placed in the service of this "greater glory." An archetype of the "good Jesuit" emerged in these writings, politically skilled, educated in science, almost as an analogue to those Victorian missionaries so valuable to the royal endeavor. The rubbing of their encounter meant that while the historical image of the Jesuits had so influenced the Protestant relationship with Abyssinia, the Protestant relationship with Abyssinia simultaneously influenced the historical re-imagining of the Jesuits.

Yet an additional observation must be set forth here, as a conjecture far beyond the boundaries of this chapter. Indeed, the rubbing between these histories has contributed to a secondary-order effect that may not be completely clear at the outset. For the Victorians themselves, and their Jesuit antecedents, both took on assumptions about their world through the transmission of historical information and intellectual encounter. This "rubbing up" against sources from earlier times contributed to certain characterizations about an "Ethiopia" that was known to "exist" somewhere in the unknown tracts of Africa. These legends, ancient tales, kept Europeans coming back, searching for the Christian Ethiopia that had been encountered yet recorded only in dusty tomes. "Ethiopia" as a place may indeed have existed more surely in the minds of these Europeans than in any particular set of local conditions or cultural memories. For the negusa negasts themselves, the "Ethiopian" identity may simply have been a strategic concept used to make connections with the outside world, a diplomatic tool in gaining resources for development. Throughout its history, a cohesive Ethiopia seems to have shifted and dissolved regularly before being revived through particular foreign expectations, themselves crafted through such historical flashes of unity. When Bruce, Salt, and Gobat arrived, they were looking for a place they knew to exist because the Jesuits had known it before. Its history was recorded, its cultural traditions and religious practices inscribed. Searching for a literary image among the realities of this world, with technical and intellectual assets to donate in hand, would certainly encourage the emergence of eager allies claiming to be just the image desired. While the negusa negast remained a titular puppet without note, he was the agent constantly sought by the Victorians due to the fact that the Jesuits had known and treated with him. Tewodros II stood up to fill that office upon which foreign visitors of import increasingly called. This leads to the 
possible conclusion that the very idea of Abyssinia, of modern Ethiopia, was a creation sustained over time, at least in part by the rubbing up of these historical narratives across the eras. This literary encounter forged living memories of a place and a people that may have vanished entirely otherwise. Therefore, this encounter between Jesuits and Protestants, the rubbing up of their histories, operated in a network of intellectual and material incentives; those same dynamics that create and power "imagined communities."

\section{Bibliography}

Álvares, Francisco. Narrative of the Portuguese Embassy to Abyssinia during the Years 1520-1527. Translated by Henry Edward John Stanley. London: Hakluyt Society, 1881. Barbosa, Duarte. A Description of the Coasts of East Africa and Malabar in the Beginning of the Sixteenth Century. Translated by Henry Stanley. London: Hakluyt Society, 1866.

Cooke, A.C. [Anthony Charles]. Routes in Abyssinia. London: Harrison and Sons, 1867.

Crawford, O.G.S. [Osbert Guy Stanhope], ed. Ethiopian Itineraries, circa 1400-1524, Including Those Collected by Alessandro Zorzi at Venice in the Years 1519-1524. Cambridge: Hakluyt Society, 1958.

Gabre-Sellassie, Zewde. Yohannes IV of Ethiopia: A Political Biography. Oxford: Clarendon, 1975 .

Gobat, Samuel. Three Years' Residence in Abyssinia. New York: M.W. Dodd, 1850.

Grand, Joachim Le. A Voyage to Abyssinia, by Father Jerome Lobo, a Portuguese Missionary, Containing the History, Natural, Civil, and Ecclesiastical, of That Remote and Unfrequented Country. Translated by Samuel Johnson. London: Elliot and Kay, 1789 .

Hakluyt, Richard. The Principal Navigations Voyages Traffiques \& Discoveries of the English Nation, Made by Sea or Over-land to the Remote and Farthest Distant Quarters of the Earth at Any Time within the Compasse of These 1600 Yeers, Vols I-X. Glasgow: James MacLehose and Sons, 1903 .

Harris, William Cornwallis. The Highlands of Aethiopia. London: Longman, Brown, Green and Longmans, 1844.

Henze, Paul. Layers of Time: A History of Ethiopia. New York: St. Martin's Press, 2000.

Isenberg, Charles William. Journals of Rev. Messrs. Isenberg and Krapf, Missionaries of the Church Missionary Society, Detailing Their Proceedings in the Kingdom of Shoa, and Journeys to Other Parts of Abyssinia, in the Years 1839, 1840, 1841, and 1842. London: Seeley, 1843.

Krapf, J. Lewis. Travels, Researches, and Missionary Labors during an Eighteen Years' Residence in Eastern Africa. London: Trubner and Co., 1860.

Lobo, Jerónimo. The Itinerário of Jerónimo Lobo. Translated by Donald M. Lockhart. London: Hakluyt Society, 1984. 
Ludolf, Hiob. A New History of Ethiopia. Translated by J.P. Gent. London: Samuel Smith, 1682.

Macqueen, James. A Geographical Survey of Africa. London: B. Fellowes, 1840.

Markham, Clements R. A History of the Abyssinian Expedition. London: Macmillan and Co., 1869 .

Markham, Clements R. "The Portuguese Expeditions to Abyssinia in the Fifteenth, Sixteenth, and Seventeenth Centuries." Journal of the Royal Geographical Society of London 38 (1868): 1-12.

Markus, Harold. A History of Ethiopia. Berkeley: University of California Press, 1994.

Páez, Pedro. Pedro Páez's History of Ethiopia, 1622, Vols I-II. Edited by Isabel Boavida, Hervé Pennec, and Manuel João Ramos. London: Hakluyt Society, 2011.

Pankhurst, Richard. An Introduction to the Economic History of Ethiopia from Early Times to 180o. London: Lalibela House, 1961.

Parkyns, Mansfield. Life in Abyssinia: Being Notes Collected during Three Years' Residence and Travels in That Country, Vols I-III. New York: D. Appleton Company, 1854.

Pennec, Hervé. "Missionary Knowledge in Context: Geographical Kknowledge of Ethiopia in Ddialogue during the 16th and 17th Ccenturies," in African History: Written Culture in a Colonial Context, Vol II: Africa and the Americas 1500-1900, eds. Adrien Delmas and Nigel Penn (Boston: Brill, 2012): 75-96.

The Periplus of the Erythraean Sea. Translated by G.W.B. [George Wynn Brereton] Huntingford. London: Hakluyt Society, 1980.

The Red Sea and Adjacent Countries at the Close of the Seventeenth Century, as Described by Joseph Pitts, William Daniel, and Charles Jacques Poncet. Translated by William Foster. London: Hakluyt Society, 1949.

Russell, Michael. Nubia and Abyssinia, Comprehending Their Civil History, Antiquities, Arts, Religion, Literature, and Natural History. Edinburgh: Oliver \& Boyd, 1833.

Salt, Henry. A Voyage to Abyssinia, and Travels into the Interior of That Country, Executed under the Orders of the British Government in the Years 1809 and 1810 . London: F.C. \& J. Rivington, 1814 .

Sanceau, Elaine. The Land of Prester John. New York: Knopf, 1944.

Shaw, Samuel. An Interesting Narrative of the Travels of James Bruce, Esq. into Abyssinia, to Discover the Sources of the Nile, Abridged from the Original Work. London: B.D. Symonds, 1800 .

Ullendorff, Edward. The Ethiopians: An Introduction to the Country and People. London: Oxford University Press, 1965.

Waddington, George, and Barnard Hanbury. Journal of a Visit to Some Parts of Ethiopia. London: John Murray, 1822.

Wansleben, Michael Johann. A Brief Account of the Rebellions and Bloodshed Occasioned by the Anti-Christian Practices of the Jesuits and Other Popish Emissaries in the Empire of Ethiopia. London: Jonathan Edwin, 1679.

Zewde, Bahru. A History of Modern Ethiopia 1855-1974. London: James Currey, 1991. 


\title{
A Protestant Verdict on the Jesuit Missionary Approach in Africa: David Livingstone and Memories of the Early Jesuit Presence in South Central Africa
}

\author{
Festo Mkenda, s.J.
}

David Livingstone $\left({ }^{1813-73)}\right.$ is a larger-than-life figure in the history of Christian missions in Africa. However, reaching Africa for the first time in 1841, he is far from being the continent's first missionary. His first contact with Africa was mediated by Robert Moffat (1795-1883), a Scottish Congregationalist missionary, who had already settled at Kuruman in today's South Africa in 1817, and who would later become Livingstone's father-in-law. More importantly, Livingstone himself noticed the marks left behind by Jesuit missionaries who had evangelized in the lands he was visiting before departing from the region close to a century before his own arrival. In his writings, Livingstone made mostly anecdotal references to these Jesuits, yet he believed he had observed enough of their legacy in southern Africa to enable him to comment on their missionary methods and achievements. While he praised the way the Jesuits financed their missions and the success they had in their educational work among native Africans, he was scathing about their failure to impart durable faith in their African converts, a failure he attributed to the Jesuits' Catholic background and their associations with the slave-dealing Portuguese authorities.

Livingstone's assessment of Jesuit success and failure in south central Africa calls for a deeper analysis. His verdict is best understood within the context of his own mission to Africa, more specifically as a Protestant evangelizer, an anti-slavery campaigner, and a pioneer of a commercial empire. ${ }^{1}$ Moreover, his experience as a medical doctor, a British consul, and an explorer also contributed to determining what he admired or criticized the Jesuits for. ProtestantCatholic competition, often marked by less than civilized language, is an essential element of the nineteenth-century Christian evangelization of the

1 See J.P.R. [John Peter Richard] Wallis, ed., The Zambezi Expedition of David Livingstone 1858-1863, 2 vols. (London: Chatto \& Windus, 1956), 1: xi. 
African interior. This so-called third-wave of evangelization was taking place at a time when notions of ecumenism and a desire for unity among different Christian denominations were still in their infancy. Statements by someone like Livingstone, who had such a towering influence across denominational boundaries, help us understand not only his own opinion at the time but also the ways in which African Christianity can be viewed today.

\section{Protestants and Catholics in Nineteenth-Century Africa}

During the first half of the nineteenth century, most of the African interior was an open missionary field. Between 1818 and 1850, the Catholic presence was limited to fourteen locations, most of which were situated along the coast (Algeria, Egypt, Gabon, Natal, and Cape Colony) or on the islands (Madagascar, Mauritius, the Comoros, and the Réunion). There were only two Catholic initiatives in the interior during this time: in Ethiopia (established in 1836 and 1846) and Sudan (established in 1846). In the early part of the nineteenth century, the French journal Annales de l'Association de la propagation de la foi had sections containing extensive reports from Catholic missions in Asia and the Americas, but it reported literally nothing from Africa. A Catholic desire to penetrate the interior of Africa was itself aroused at least in part by increased Protestant missionary activity. ${ }^{2}$

In the period under consideration, Protestant churches and individuals took the lead in preaching the Gospel to native Africans in the interior. Dr. Johannes Theodorus van der Kemp (1747-1811), commonly referred to as Doctor Vanderkemp, ${ }^{3}$ was one of the first three pioneers of the London Missionary Society (LMS) in southern Africa. He reached the Khoikhoi and the Xhosa in that region and even learned their languages. Moffat, who was a close follower of Vanderkemp, worked mainly among the Tswana people, translating the New Testament into their language. These Protestant missionaries had a free field without Catholic competition, and they thus made little or no reference to the Catholics. In the dedication of his book to His Royal Highness Francis Albert Augustus Charles Emmanuel, duke of Saxe (1819-61), Moffat praised the house of Saxony for standing by Martin Luther (1483-1546), whom he acknowledged as "the great Reformer," and for offering him protection "against the power of

2 Ronald Werner, William Anderson, and Andrew Wheeler, Day of Devastation, Day of Contentment: The History of the Sudanese Church across 2000 Years (Nairobi: Paulines Publications Africa, 2000), 131 .

3 See A.D. [Arthur David] Martin, Doctor Vanderkemp (London: Livingstone Press, 1931). 
Rome." ${ }^{4}$ This is the only reference that gives an indication of Moffat's view of Catholicism as a threat. However, rather than being incidental to Moffat's account, the reference to "the power of Rome" and the implied need to combat it belonged to a larger narrative that became more pronounced in the second half of the nineteenth century.

An article by one "K," published in the July 1886 issue of the Protestant journal The Church Missionary Intelligencer and Record, bore the title "On the Character of Jesuit Missionary Teaching." It offered a Protestant assessment of the Jesuits, not only in Africa but throughout the order's history. Regularly referring to the Catholic Church as the "Romish Church," the article is not strictly representative of Protestant opinion at the time but it certainly serves to highlight some extreme Protestant views about Catholics and, more specifically, the Jesuits. The Catholic missionary record in Africa, as in other places, appears rather pitiable in the article. Speaking about Catholic missions that had "long since melted away like foam upon the waters," whose very existence "is unknown, except to curious inquirers into the records of the past," the article mentions Africa as a place that "teems with instances of such desolation, among what are said once to have been flourishing Romish Missions." But even here, the article says, "there has been a complete and utter disappearance of them; they have passed away, and have not left a wrack behind to intimate that they once had a being." Despite such a critical view, the article delicately combines praise to Catholic authorities for dealing firmly with the Jesuits with acknowledgment of Jesuit missionary achievement in previous centuries: "Rome would show badly, notwithstanding her early start in the field, if it had not been for the Jesuit body": 5

The all-important question, however, for consideration in a periodical like ours is not what was the skill or success of the Jesuits as explorers, or rulers, or scientific teachers, or even promoters of civilization among wild and barbarous tribes, but what was the nature and character of their teaching as professed ministers and evangelists of Christianity. The utmost that their friends and admirers might wish to claim for them might be readily conceded in many secular matters, and yet there might be a woful [sic] defect in the substance of their spiritual teaching and their method of communicating it, which would make them hinderers rather than promoters of the Gospel. As extremes not unfrequently [sic] meet, it

4 Robert Moffat, Missionary Labours and Scenes in Southern Africa (London:John Snow, 1842), i.

5 K., "On the Character of Jesuit Missionary Teaching," Church Missionary Intelligencer and Record (July 1886): 529-44, here 530. 
might be that a cold, calculating political economist like John Stuart Mill could perceive in Jesuit operations concerning temporal matters what he could largely approve of, and yet that if their proceedings were weighed in the balances of the sanctuary they might be found to be of little or no value at all. ${ }^{6}$

A key line of argument in this quotation is that, even if Jesuits were successful in social and economic areas of the secular order of things, such success could not make up for their failure to pass on the Christian faith to people in mission territories. Although a generalization, this assessment is critically important in Africa, where the Catholic faith the Jesuits preached and its public manifestation in practice had largely vanished from the regions that Livingstone visited in the middle of the nineteenth century.

\section{Livingstone on Jesuit Missionary Economics in Africa}

A Scotsman, Livingstone trained as a medical doctor, eventually becoming an anti-slavery campaigner, a Christian missionary, an explorer, and a British consul. As a missionary, his eyes were first fixed on China. He turned to Africa only after the Opium Wars (1839-42 and 1856-6o) had denied him access to the country of his first missionary dream. It is said that, as a scientist and believer, he "saw no conflict between faith and scientific understanding." His "Christianity had a strong practical bent" and his faith made him devote his "life to the alleviation of misery." Livingstone's rich background made him view his missionary activity in the broadest terms possible, thereby avoiding the secular-religious dichotomy that is apparent in the extreme position outlined above. In a speech delivered in Senate House, Cambridge, in 1857, he said, "I might have gone on instructing the natives in religion, but as civilization and Christianity must go on together, I was obliged to find a path to the sea, in order that I should not sink to the level of the natives." ${ }^{8} \mathrm{He}$ firmly believed

6 Ibid., 535 .

7 Willie Henderson, "Livingstone, David," in Dictionary of African Biography, ed. Emmanuel K. Akyeampong and Henry Louis Gates Jr., 6 vols. (Oxford: Oxford University Press, 2012), 3: 510-12, here 510; see David Livingstone, Missionary Travels and Researches in South Africa: Including a Sketch of Sixteen Years' Residence in the Interior of Africa (London: Ward, Lock \& Co., 1857), 4.

8 David Livingstone, David Livingstone and Cambridge: A Record of Three Meetings in the Senate House (London: Universities Mission to Central Africa, 1908), 9. 
in the triad of civilization, commerce, and Christianity and worked tirelessly to introduce the three into Africa. In fact, for Livingstone, civilization (meaning "European civilization") was the ultimate goal, one that was midwifed by Christianity and commerce: "Those two pioneers of civilization-Christianity and commerce-should ever be inseparable; and Englishmen should be warned by the fruits of neglecting that principle as exemplified in the result of the management of Indian affairs,"9 he said.

Given his broad disposition, the great missionary was well positioned to look at the Jesuits more favorably than some of his fellow missionaries, admiring them for their achievements in commerce and education and recommending them for Protestant imitation, even as he mourned their dismal performance in religion. He carefully observed Jesuit markings in south central Africa and missed no opportunity to mention them in his letters, speeches, and writings. He took note of nearly any mention of the Jesuits in south central Africa on any topic, however unsubstantiated the claims made about them appeared to be.

In an 1860 letter to Admiral Sir Frederick William Grey, K.C.B. (1805-78), Livingstone mentioned the doubtful existence of a silver mine "said to have been worked by the Jesuits of old," which some members of his expedition were working tirelessly to rediscover..$^{10}$ There is hardly any mention of Jesuitowned silver mines or any silver mines at all in other sources related to the sixteenth- and seventeenth-century missions in the region. Elsewhere, Livingstone attributed the introduction of coffee and species of fruits and trees to Angola that he considered useful for timber to the Jesuits and other missionaries. ${ }^{11}$ In his estimation, mangoes, oranges, cashews, and other farm produce were "all fruits of the Jesuits' labour."12 The link between Jesuits and coffee, like that with silver mines, is somewhat problematic too. More recent authors date the introduction of the crop to Angola in the $1830{ }^{13}{ }^{13}$ yet, after their expulsion in 1759 , Jesuits did not return to the country until 1967.

$9 \quad$ Ibid., 13.

$10 \quad$ Wallis, Zambezi Expedition, 1: 157.

11 Livingstone, Missionary Travels, 346.

12 Isaac Schapera, ed., David Livingstone: Family Letters 1841-1856, 2 vols. (London: Chatto \& Windus, 1959), 2: 277.

13 See Bayetta Bellachew, "A Brief Account of Coffee Production in Angola: A Quick Assessment," Travel Report no. 11, Inter Africa Coffee Organization \& African Coffee Research Network (June 2015), 1, available online at http://www.iaco-oiac.org/sites/default/files/ travel_report_no_11_-_angola_o.pdf (accessed May 29, 2017); Yonah Seleti, "Finance Capital and the Coffee Industry of Angola 1867-1895," Transafrican Journal of History 16 (1987): 63-77, here 63 . 
Livingstone was more accurate when it came to the other things he attributed to the Jesuits. While exploring the vast territory that constitutes Congo and Angola today, he counted more than twelve abandoned churches, which he believed had belonged to the Capuchins and the Jesuits. It is quite possible that Livingstone would have seen the church of Our Lady of Victory at Masanganu near Dondo, built by Paulo Dias de Novais $(c .1510-89),{ }^{14}$ the first Portuguese governor whom the Jesuits accompanied to Angola. He certainly saw the Church of Jesus and the College of Jesus in Luanda, the undisputed seventeenth-century Jesuit monuments in that city. ${ }^{15}$

Similarly accurate was Livingstone's observation of the fruits of Jesuit labor in African education. When he visited the former site of the missionary station of Cahenda, located about twelve miles north of Ambaca, he was pleasantly surprised by "the great numbers who can read and write." This he attributed to the Capuchins and the Jesuits, and the fact that fond memories of the Jesuits still existed in the place would seem to confirm his conclusions. "Ever since the expulsion of the teachers by the Marquis of Pombal," he noted, "the natives have continued to teach each other."16 Manifesting deliberate focus on a subject of great personal interest and introducing a comparison that betrays his preference for Jesuits, Livingstone dwelled on this observation in an 1854 letter to his brother Charles Livingstone (1821-73):

I have been examining some of the old Jesuit Mission stations in the country, and the fruits of their labours. From all accounts the Jesuits were very exemplary in their lives, and devoted themselves to the instruction of the people conscientiously. The effect of their efforts is seen in the numbers who can read \& write in the country. They teach each other now, and in the district of Ambaca it is considered a disgrace for any one to be unable to read. When the Jesuits were expelled from Portuguese territory by the Marquis of Pombal, the place of the Jesuits was supplied by a batch of the regular priesthood, with fine long beards. These were graceless bardies, who loved to tuck up their habits and join in the dances of the Natives [...]. The people could tell nothing about these last batch except their fine beards. ${ }^{17}$

14 See Emanuel Cabaco et al., As Igrejas monumentos de Angola: Exposição fotográfica (Luanda: Festival Nacional de Cultura de Angola and Instituto Nacional do Património Cultural, 2014), 51-53.

15 Livingstone, Livingstone and Cambridge, 23; see Cabaco et al, Igrejas monumentos, 74-77.

16 Livingstone, Missionary Travels, 330.

17 Schapera, David Livingstone, 2: 255 . 
In sharp contrast, Livingstone reported in an 1856 letter to his father-in-law that there were no similar remains of Jesuit teaching in Mozambique. ${ }^{18}$

Besides their reported success in education, Jesuits also scored high on trade and, more generally, on organizational style. It is worth reemphasizing here that Livingstone appears to praise in the Jesuits what he himself wished to promote. For Livingstone, commerce was a path to "civilization," and anything he might learn from the Jesuits in this regard was likely to advance his own course. Moreover, like many other missionaries of his time, Livingstone was financially under-supported. He betrayed a degree of frustration with Christians in Britain who considered their donations to support missionaries as "charity" rather than as their share of a common obligation to "go into all the world and preach the gospel to every creature." 19 In fact, at some point the LMS viewed his activities to be connected "only remotely with the spread of the gospel" and thus felt unable to continue aiding his plans financially, forcing him to consider accepting a government-sponsored consular position. ${ }^{20}$ At this point, Livingstone became-as one author describes him - "more of a public scientist than a gospel evangelist."21 It was within this context of limited resources for mission that he argued for the need to combine missionary work and trade in the same person, saying that such a combination

would not be morally wrong, for nothing would be more fair, and apostolical too, than that the man who devotes his time to the spiritual welfare of a people should derive temporal advantage from upright commerce, which traders, who aim exclusively at their own enrichment, modestly imagine ought to be left to them. ${ }^{22}$

To this end, therefore, Livingstone was willing to cross all denominational boundaries to learn from previous missionary experiences. "In the early ages the monasteries were the schools of Europe," he said, "and monks were not ashamed to hold the plough."23 The Dutch clergy, who were "not wanting in worldly wisdom," were a model to emulate too. With them,

18 Ibid., 2: 284 .

19 Livingstone, Missionary Travels, 30; also see Livingstone, Livingstone and Cambridge, 26.

20 Wallis, Zambezi Expedition, 1: xvi, xx, xxii-xxiv.

21 Shanet Clark, "Dr. David Livingstone: Cultural Approaches to an Important Victorian Figure," Education Forum, 2005, available online at http://educationforum.ipbhost.com/ index.php?/topic/3895-dr-david-livingstone/ (accessed May 29, 2017).

22 Livingstone, Missionary Travels, 29.

23 Livingstone, Livingstone and Cambridge, 14. 
a fountain is bought, and the lands which it can irrigate parcelled out and let to villagers. As they increase in numbers the rents rise and the church becomes rich. With £20o per annum in addition from Government, the salary amounts to $£ 400$ or $£ 500$ a year. The clergymen then preach abstinence from politics as a Christian duty. It is quite clear that, with $£_{400}$ a year, but little else except pure spirituality is required. ${ }^{24}$

The admired monks were in Europe, and we are not sure where the Dutch clergy were, although they could have been in South Africa at that time. It is clear, however, that the Jesuits in south central Africa were the model missionary-traders in the imagination of Livingstone; in fact, the example of the Dutch clergy was just an illustrative footnote after a lengthy description of the Jesuits. Probably not without exaggeration, Livingstone said:

The Jesuits, in Africa at least, were wiser in their generation than we; theirs were large influential communities, proceeding on the system of turning the abilities of every brother into that channel in which he was most likely to excel; one, fond of natural history, was allowed to follow his bent; another, fond of literature, found pleasure in pursuing his studies; and he who was great in barter was sent in search of ivory and gold-dust; so that while in the course of performing the religious acts of his mission to distant tribes he found the means of aiding effectively the brethren whom he had left at the central settlement. We Protestants, with the comfortable conviction of superiority, have sent out missionaries with a bare subsistence only, and are unsparing in our laudations of some for not being worldly-minded whom our niggardliness made to live as did the prodigal son. ${ }^{25}$

In a similar vein, Livingstone was inclined to give a positive assessment of Jesuit work in Mozambique, even though he admitted that their performance there could not match up to that in Angola. Describing a former Jesuit settlement he saw about ten miles southeast of Tete, he confessed to have observed that "both judgment and taste had been employed in the selection of the site," as indeed "in all their settlements." Here, "a little stream of mineral water had been collected in a tank and conducted to their house, before which was a little garden for raising vegetables at times of the year when no rain falls." Like their brethren in Angola, Jesuits in Mozambique are described as great traders:

24 Livingstone, Missionary Travels, $29 n 1$.

25 Ibid., 29. 
"Large quantities of gold had often been sent to their superiors in Goa," said Livingstone, adding that the Jesuits "were keen traders in ivory and gold dust" and that "all praise their industry" because "whatever they did, they did it with all their might." Speaking about their expulsion from Mozambique, which happened in 1759, Livingstone mourned "the riches of the fraternity, which were immense." As these were confiscated by the state, Livingstone concluded that "probably their [Jesuits'] successful labours in securing the chief part of the trade to themselves had excited the envy of the laity."26

When the Jesuits did not own the praised farms themselves, Livingstone attributed to them the wisdom that influenced their choice of location. Talking about one such farm at Zumbo in today's Mozambique, he said: "The early traders, guided probably by Jesuit missionaries, must have been men of taste and sagacity." Like the Jesuits, they too

selected for their village the most charmingly picturesque site in the country, and had reason to hope that it would soon be enriched by the lucrative trade rivers Zambesi and Luangwa pouring into it from the north and the west, and by the gold and ivory of the Manica country on the south. ${ }^{27}$

It is now known for certain that the Jesuits owned huge tracts of land in Mozambique. They may also have been traders as described, even though the degree of their economic success is open to question. As Jesuit historian William Francis Rea (1908-80) later demonstrated, the Jesuit missions in Mozambique were economically stressed and stood little chance of success even if the expulsion had not happened in $1759 .{ }^{28}$ However, this should not distract us from Livingstone's key point about the economics of missionary survival, in which he believed Jesuits excelled. From this viewpoint, Livingstone would not endorse the summary assertions of the mid-seventeenthcentury Angolan political class that "the fathers had deserted God in favour of Mammon."29 Nor would he have been privy to the late nineteenth-century

\footnotetext{
$26 \quad$ Ibid., 551.

27 David Livingstone and Charles Livingstone, Narrative of an Expedition to the Zambesi and Its Tributaries; And of the Discovery of the Lakes Shirwa and Nyassa, 1858-1864 (London: John Murray, 1865), 203.

28 William Francis Rea, The Economics of the Zambezi Missions 1580-1759 (Rome: IHSI, 1976), 171.

29 Dauril Alden, The Making of an Enterprise: The Society of Jesus in Portugal, Its Empire, and Beyond, 1540-1750 (Stanford: Stanford University Press, 1996), 217.
} 
opinion, cited previously, that Jesuit operations in temporal matters could be admired only by "a cold, calculating political economist like John Stuart Mill" and were "of little or no value at all" in the balances of the sanctuary. ${ }^{30}$ For Livingstone, commerce, Christianity, and civilization were too intricately connected to allow for such a clear-cut distinction between the sacred and the secular, and, in the context of meagre resources from Christians in Europe to missions in Africa, missionaries had better lived with the wisdom of serpents even as they pursued the innocence of doves. In his view, the Jesuits in Africa did just that.

\section{Livingstone on the Jesuit Christian Legacy in Africa}

While he approved of Jesuit missionary methods in Africa, Livingstone brooded over Christianity's almost complete disappearance from the lands they had evangelized for so many years. His description of this missionary failure as observed in one location in Mozambique is sobering:

The chapel, near which lies a broken church bell, commands a glorious view of the two noble rivers [...]. It is an utter ruin now, and desolation broods around [...]. The foul hyena has defiled the sanctuary, and the midnight-owl has perched on its crumbling walls to disgorge the undigested remnant of its prey. One can scarcely look without feelings of sadness on the utter desolation of a place where men have met to worship the Supreme Being, or have united in uttering the magnificent words, "Thou art the King of glory O Christ!" and remember, that the natives of this part know nothing of His religion, not even His name; a strange superstition makes them shun this sacred place, as men do the pestilence, and they never come near it. Apart from the ruins, there is nothing to remind one that a Christian power ever had traders here; for the natives of to-day are precisely what their fathers were, when the Portuguese first rounded the Cape. Their language, unless buried in the Vatican, is still unwritten. ${ }^{31}$

For Livingstone, the Jesuit failure to pass on a kind of faith that could propagate itself was seriously disturbing. While they preserved so many other Jesuit relics, native Africans had held tenaciously to their ancestral religion as though

30 K., "Character of Jesuit Teaching," 530.

31 Livingstone and Livingstone, Narrative of Expedition, 204. 
they had never encountered Christianity. Livingstone could observe that Africans had "a clear idea of a Supreme Being, the maker and governor of all things," that they "promptly acknowledge him as the ruler over all," and that they "also fully believe in the soul's continued existence apart from the body."32 However, in his estimation, the practical expression of that faith showed no link to earlier contacts with Christianity: "They pray to their departed relatives, by whom they imagine illnesses are sent to punish them for any neglect on their part";3 "When they escape, or recover from sickness, or are delivered from any danger, they offer a sacrifice of a fowl, or a sheep, pouring out the blood as a libation to the soul of some departed relative"; 34 "They believe in the transmigration of souls; and also that while persons are still living they may enter into lions and alligators, and then return again to their own bodies." ${ }^{35}$ From these observations, it became obvious to Livingstone that the natives who had encountered the Jesuits in south central Africa were at least non-Christians if not raw heathens.

Livingstone was thus confronted with a serious question about what exactly went wrong with the missionary predecessors he so much admired. "Since the early missionaries were not wanting in either wisdom or enterprise," he mused, "it would be interesting to know the exact cause of their failing to perpetuate their faith." ${ }^{36}$ And, indeed, if the Ambacans could pass on the skill of reading and writing from one generation to another long after their teachers had been sent away, could they not have done the same with the faith of their evangelizers? To satisfy himself, Livingstone attempted a two-point response.

In the first part of his response, Livingstone judged that failure to pass the Christian scriptures on to native converts could have undermined the work of the Jesuits. Addressing them as "these our Roman Catholic fellow-Christians," Livingstone argued that the Jesuits and the other Catholic missionaries in south central Africa had kept the Bible to themselves, leaving their converts with nothing that could have become "a light to their feet when the good men themselves were gone. ${ }^{37}$ Indeed, there are records of catechisms and prayerbooks authored or translated by Jesuits in seventeenth-century south central Africa, ${ }^{38}$ but there is no evidence of a Jesuit attempt to render the scriptures

32 Livingstone, Missionary Travels, 550.

33 Livingstone, Livingstone and Cambridge, 12.

34 Livingstone, Missionary Travels, 550.

35 Ibid.

36 Livingstone and Livingstone, Narrative of Expedition, 204.

37 Livingstone, Missionary Travels, 330.

38 In Angola, Mateus Cardoso (1584-1625) translated the Cartilla de la sagrada doctrina into Kikongo in 1624, and a catechism by António do Couto (d. 1666) was published in 
accessible to native Africans in their own languages during this period. Elsewhere, Livingstone noted that the only books native Africans possessed were "histories of saints, and miracles effected by the parings of saintly toe-nails, and such like nonsense."39 Reading this line, one cannot help seeing a connection to broader Protestant opinion, especially with John Calvin's (1509-64) Treatise on Relics (1543) in which Calvin considered it a well-known fact "that the most part of the relics which are displayed everywhere are false, and have been put forward by impostors who have most impudently deceived the poor world."40 Nevertheless, Livingstone would further argue that, "if such an impression has once been produced, it might be hoped that the efforts of other missionaries, who would leave the Bible with these poor people, would not be less abiding." ${ }^{41}$

Generally lauded as even-handed on denominational matters, ${ }^{42}$ Livingstone betrays a view about the effectiveness of the Bible as a tool for evangelization that brings out the Protestant in him and probably manifests a clear Protestant-Catholic distinction in his thinking. In this, he would have been informed by the sola scriptura considerations that had characterized interdenominational debates since the Diet of Worms in $15^{21 .} .^{43}$ More immediately, Livingstone had observed and commented positively on the modest missionary successes of Moffat, his father-in-law, among the Tswana after he had translated the scriptures into their language. ${ }^{44}$ He viewed Moffat's translation as "a great work and likely to be of permanent benefit to the people." ${ }^{45} \mathrm{He}$ also cited Madagascar as an example of a place where the Bible had helped Christianity endure in difficult circumstances. There, he said,

Kimbundu in 1642, whereas in Mozambique Livingstone learned that Jesuits had translated prayers into local languages. See Livingstone, Missionary Travels, 551, and José Vaz de Carvalho, "Angola," in Diccionario histórico de la Compañía de Jesús: Biográfico-temático, ed. Charles E. O'Neill and Joaquín M. Domínguez, 4 vols. (Roma: IHSI, 2001), 1: 171-5, here 174 .

39 Livingstone, Livingstone and Cambridge, 12.

40 John Calvin, A Treatise on Relics, trans. Valerian Krasinski, 2nd ed. (Edinburgh: Johnstone, Hunter \& Co., 1870), 165 .

41 Livingstone, Livingstone and Cambridge, 12.

42 Henderson, “Livingstone," 510.

43 See Georges Tavard, Protestantism, trans. Rachel Attwater (New York: Hawthorn Books, 1959), 19-31. Sola scriptura, Latin for "by scripture alone," refers to the theological position that Christian scriptures alone are the infallible rule of faith and practice, which was at the center of the Catholic-Protestant disagreements following the sixteenth-century Reformation.

44 See Livingstone, Livingstone and Cambridge, 17.

45 Schapera, David Livingstone, 2: 120. 
a few Christians were left with nothing but the Bible in their hands; and though exposed to persecution, and even death itself, as the penalty of adherence to their profession, they increased tenfold in numbers, and are, if possible, more decided believers now than they were when, by an edict of the queen of that island, the missionaries ceased their teaching. ${ }^{46}$

Clearly, Livingstone viewed the Bible as key to any missionary success, and to the extent that the Jesuits failed to pass it on to native Africans, their missionary admirer could not recommend them for Protestant imitation.

Even then, Livingstone's tone remains sympathetic to the Jesuits. Despite the failures he attributed to them, they still remained "our Roman Catholic fellow-Christians," not the "Janissaries of the Church of Rome" that " $\mathrm{K}$ " had contemplated them to be. ${ }^{47}$ This is probably because Livingstone himself, while holding to a properly Protestant view, harbored doubts about the Bible's own power to impart self-perpetuating faith. It would appear that his hope for biblical efficacy was pegged on the consideration that the scriptures, now introduced by Protestants, would create at least as much of a lasting impression as the stories of saints and relics, left behind by Jesuits, had created in African minds. Moreover, even as he praised Moffat's translation of the Bible, he was honest enough to admit that other factors might determine whether or not its impact would last. The Tswana could cease to exist as a people, for example, or their language could simply die out. To Moffat, Livingstone wrote:

Pity your Bible was not translated into negro language, the population is so large and fond of learning. They are an indistructible [sic] race, and, no mistake, they are very prolific. I have had doubts as to the imperishability of the Bechuanas. The Makololo are fast dying out, they don't bring forth like the negroes. The Bakwains are ridiculously impotent. Several other considerations make me fear for their permanence, and with that fear the apprehension that your noble work of translation may come to the same end with Elliot's Choctaw Bible, which lies on a shelf in one of the American colleges, a monument of devotedness an[d] zeal in a language which no living jaws can articulate nor mortal understand. If such a sad consummation should ensue, and I confess I have serious fears that the present Colonial policy tends to accomplish it, your labour of love will

46 Livingstone, Missionary Travels, 102.

47 K., "Character of Jesuit Teaching," 544 . "K" uses this term as he compares the Jesuits with Turkish Janissaries, who constituted a highly disciplined elite royal force in the Ottoman Empire and lasted from the fourteenth to the nineteenth century. 
be none the less appreciated by Him who placed you where you are, and whose smile of "Well done" will soothe the soul to everlasting peace. ${ }^{48}$

John Eliot (1604-90) translated the Bible into the language of the now extinct Massachusetts Indians that lived around Boston (though not Choctaw, as Livingstone thought), which is utterly unusable except for archival display. ${ }^{49}$ Yet, missionary labor like that of Eliot, even when it does not produce tangible earthly fruit in the form of lasting conversions, remains a labor of love worthy of eternal reward. Here lies Livingstone's missionary pragmatism, which would not allow him to throw too heavy a blow on the Jesuits.

The second part of Livingstone's response to his own question focused on the slave trade, a practice he considered alien to Africa. Livingstone had no doubt whatsoever that trade in humans was an evil introduced to Africa by the Portuguese, which then hindered the implantation of Christianity on the continent. If all the progeny of the whites were to leave Africa, he said, "their only memorial would be the ruins of a few stone and mud-built walls, and that blighted relic of the slave-trade, the belief which is not of native origin, for it is not found except in the track of the Portuguese. ${ }^{50} \mathrm{He}$ was further convinced that the operations of those systems that sanctioned slavery, be they of native or European origin, only perpetuated "barbarism,"51 which must be contrasted to the "civilization" that Livingstone himself so intricately linked to Christianity and to what later became known as legitimate commerce. ${ }^{52}$

In Livingstone's view, the Jesuits, as indeed all early missionaries in south central Africa, were too enmeshed in the systems that sanctioned the trade in humans for their faith to be taken seriously by the natives they sought to convert. He first proposed this conclusion in the form of a question: "Can it be that the Missionaries of old, like many good men formerly among ourselves, tolerated this system of slave-making, which inevitably leads to warfare, and thus failed to obtain influence over the natives by not introducing another policy than that which had prevailed for ages before they came?"53 He quickly followed this tentative position with the more affirmative statement that a

48 Schapera, David Livingstone, 2: 263; also see Livingstone, Livingstone and Cambridge, 15.

49 Schapera, David Livingstone, 2: $263 n 7$.

50 Livingstone and Livingstone, Narrative of an Expedition, 204; also see Wallis, Zambezi Expedition, 1: xiv.

$5^{1} \quad$ Livingstone and Livingstone, Narrative of Expedition, 204.

$5^{2}$ See Livingstone, Livingstone and Cambridge, 12-13, 23-26; also see Robin Law, ed., From Slave Trade to Legitimate Commerce: The Commercial Transition in Nineteenth-Century West Africa (Cambridge: Cambridge University Press, 1995). 
palpable anti-slavery character among native Africans excited such universal attention that "any Missionary, who winked at the gigantic evils involved in the slave-trade, would certainly fail to produce any good impression on the native mind." 54

In south central Africa, the Jesuits did more than wink at slavery and the slave trade together with their menacing consequences for native African populations. In Mozambique, they owned no fewer than seventeen big estates or prazos that were worked by an equally large number of slaves. ${ }^{55}$ It was mainly what remained of these estates that gave Livingstone an impression of "the riches of the fraternity, which were immense." ${ }^{56}$ In Angola, the Portuguese colonial structure, imposed and sustained by force, existed with tacit Jesuit approval. As mentioned earlier, Dias de Novais, the founding Portuguese governor of Angola whose full title came to be "Governor and Commander-in-Chief, Founder and Conqueror of the Kingdom of Sebaste in the Conquest of Ethiopia of Lower Guinea," enjoyed the counsel of the Jesuits, even though evidence of friction and outright disagreement appears between the religious men and their political patrons in later years. ${ }^{57}$ In the end, Angola as a Portuguese colony became what scholars have described as a "slave hunting-ground" 58 and "the largest slave port in Africa." ${ }^{59}$ Others have interpreted the Jesuit role in this development differently, with some assigning them a considerably more influential position. Historian and travel-writer Frederick Clement Christie Egerton, for example, viewed Jesuits as "missionaries of a sterner type, more austere living, and perhaps of a more decided purpose than the easy-going and tolerant clergy who had gone to Congo," and therefore probably "less subject to illusions about the motives which led ambitious native leaders to express interest in Christianity." He further contended that at some point Dias de Novais hoped to attain his ends in Angola by peaceful means, but the Jesuits who advised him "thought otherwise, and they were right." ${ }^{60}$ John Thornton,

$54 \quad$ Ibid., 206.

55 See William Francis Rea, "Agony on the Zambezi: The First Christian Mission to Southern Africa and Its Failure, 1580-1759," Zambezia 1, no. 2 (1970): 46-53, here 50; Malyn D.D. Newitt, Portuguese Settlement on the Zambesi (London: Longman, 1973), 89.

56 Livingstone, Missionary Travels, 551.

57 See Alden, Making of an Enterprise, 216-18.

58 John Baur, 2000 Years of Christianity in Africa: An African Church History, 2nd ed. (Nairobi: Paulines Publications Africa, 2009), 73 .

59 James Duffy, Portugal in Africa (Harmondsworth: Penguin, 1962), 59.

6o F. [Frederick] Clement C. Egerton, Angola in Perspective: Endeavour and Achievement in Portuguese West Africa (London: Routledge \& Kegan Paul, 1957), 44; also see Alden, Making of an Enterprise, ${ }^{-7}-76$. 
a prominent historian on the Kingdom of Kongo, has also confirmed that "the Jesuits were fierce advocates of war against the Mbundu to convert them by force," adding that "their lengthy correspondence reads as much like the chronicle of conquest as the report of missionary activities." ${ }^{1}$ Whatever their role in the enterprise, the Jesuits suffered the negative consequences of the brutal colonial conquest of Angola and of the slave-trading empire that stood upon its native societal ruins, giving some credence to the link Livingstone remarked upon between the infamous trade in humans and the dismal Christian gains that he observed.

It is important again to emphasize Livingstone's obviously tentative tone in this verdict. Even as he remained critical, he still understood that Jesuits tolerated trade as a way of making slaves "like many good men formerly among ourselves." That he talked of a "system of slave-making" as opposed to slavery in general is intriguing. It can be said with certainty that Livingstone's stand against the slave trade was absolute, and his desire to see its ending was immediate. However, his views about slavery were probably not as clear-cut. Statements like "By trading with Africa also, we should at length be independent of slave-labour, and thus discountenance practices so obnoxious to every Englishman" betray a degree of lenience, a certain hope that the practice would die out but gradually. Judging him to be "a facts man" who was realistic enough to put up with something that worked even if only with tolerable hardships, colonial administrator and author Philip Birkinshaw (1922-2014) observed in Livingstone "a surprising residue of sympathy for what one might call (by a stretch of imagination) 'decent' slavery and slave-trading." Not that Livingstone found anything to justify slavery, let alone slave-trading, but that "his emotions did not simply rush ahead of the evidence but rather accompanied it, finding the whole business at first distressing and in the end, diabolic." ${ }^{2}$ The Jesuits in south central Africa belonged to a certain age, and Livingstone seems to have judged them within their own context.

\section{Livingstone's Own Legacy}

Despite his indubitable feats, Livingstone's ambitious program for Africa was largely unfulfilled at the time of his death, making him more of a sower of seeds that others would reap than one who sat to enjoy the fruit of his

\footnotetext{
61 John K. Thornton, "Conquest and Theology: The Jesuits in Angola, 1548-1650," Journal of Jesuit Studies 1, no. 1 (2014): 245-59, here 257.

62 Philip Birkinshaw, The Livingstone Touch (London: Macdonald, 1973), 123, see also 126.
} 
own labor. Though he remained determined and optimistic to the very end, "Livingstone must have felt that he had failed," says historian Jack Simmons, not least because the slave trade still ravaged east Africa in $1873 .{ }^{63}$ Because of the seeds he had sown, however, this shameful trade was brought to a complete end in 1897 when the institution of slavery was altogether abolished after Zanzibar had become a British protectorate. Moreover, more than anything else, it is as a Christian missionary that Livingstone's legacy must be viewed. Yet, even from this aspect of his career, results were hard to come by. There is only one recorded convert baptized by Livingstone: namely Sechele I (c. 1810-92), chief of the Bakwena in today's Botswana, who later broke the missionary's heart by relapsing. But, again, if Sechele's baptism was a Christian seed, then it is one that grew to bear much fruit on its own. Despite occasional failures in practice (which came down to having intercourse with wives he had renounced at baptism), ${ }^{64}$ Sechele has been judged to have "spread Christianity more effectively than the dour Scotsman ever did."65 Indeed, Livingstone himself recorded that Sechele had "made himself the missionary to his own people." 66

With only one recorded convert to write home about, Livingstone's most important legacy in Africa, like that of the Jesuits before him, could not be in the form of Christian faith imparted to multitudes of native Africans. With years, the legacy scales tilted decidedly in favor of commerce. While the ethnographic and geographical information he generated about Africa's interior was meant to open up the continent for Christianity, commerce, and civilization, he had no control over the manner in which his successors would put it into use. The now familiar charge, that Christianity pacified Africans and European civilization alienated them from their native cosmology and so exposed them to exploitation via imperial commerce, would have shocked Livingstone. Yet seeds of that development can be traced back to him and to other contemporary missionaries and explorers. Arguing that some missionaries never actually bothered to work for conversion, historian Denis Judd says "Livingstone, arguably the most famous of them all, was far more effective as a de facto agent of the Royal Geographical Society, and hence of imperial expansion, than as a

\footnotetext{
63 Jack Simmons, Livingstone and Africa (London: English Universities Press, 1955), 153.

64 See Tim Jeal, Livingstone (London: Pimlico, 1993), 81-82.

65 Erin Rushing, "David Livingstone and the Other Slave Trade, Part I," Smithsonian Libraries, 2013, available online at https://blog.library.si.edu/2013/og/david-livingstone-and-the -other-slave-trade-part-i/\#.WCm98fl95PY (accessed May 29, 2017); also see Fred Morton, "Sechele I," in Dictionary of African Biography, 5: 318-19. 
saver of African souls." ${ }^{67}$ The founders of the African Lakes Company claimed to have started their business in central Africa "in response to the call of David Livingstone, who declared that two conditions were essential for the abolition of the terrible slave trade in the Dark Continent-Christianity and legitimate commerce." ${ }^{68}$ Although generations set them apart, Livingstone and Cecil Rhodes (1853-1902) have also been somewhat connected. Rhodes's territorial imagination in central Africa was informed by Livingstone's "discoveries." As he negotiated for boundaries, he was careful to exploit the sentimental interest of the British people in the Stevenson road connecting Lakes Tanganyika and Malawi because of its association with Livingstone, as well as the tree near Lake Bangweulu, where the missionary died ${ }^{69}$ It becomes obvious, therefore, that by "exploring and, by extension, [...] claiming south central Africa for his native Britain, Livingstone's legacy becomes entwined with that of Cecil Rhodes."70 Some authors have gone further to establish a parallel at least in character between Livingstone and Britain's most accomplished imperialist in Africa: peerless leadership, secluded, inspiring, and hardworking. ${ }^{71}$ Church authorities, politicians, and servants of empire have linked the two by "a combined memorial to these two famous men, in the fulfilment of whose ideals lies the best hope for the future of British Central Africa." ${ }^{72}$

It would be harsh to conclude that Livingstone was a great promoter of trade but a failed Christian missionary. To look at his missionary career differently, we might re-evaluate the very standard against which he judged the Jesuits. It is quite possible that the Jesuits had greater success than Livingstone was actually disposed to seeing. In an article on Christianity in the Kongo Kingdom, Thornton makes a distinction between exclusive and inclusive concepts of Christianity, which might help us see the point. Whereas exclusive Christianity, such as was applied in the Spanish colonies in the Americas, required converts to abandon their own cosmology in order to receive new faith as it were on a clean slate, inclusive Christianity, as was applied in Kongo, was

67 Denis Judd, Empire: The British Imperial Experience from 1765 to the Present (London: HarperCollins, 1996), 88.

68 Fred L.M. Moir, After Livingstone: An African Trade Romance (London: Hodder and Stoughton, 1924), 1. The author is one of two brothers who founded the company in 1877 .

69 See Basil Williams, Cecil Rhodes (London: Constable, 1938), 166-67.

70 Clark, "David Livingstone."

71 Wallis, Zambezi Expedition, 1: xi-xii.

72 From a communication signed by the archbishops of Canterbury and York, the secretary of state for the colonies, Lord Lugard, Lord Hailey, and others, appealing for funds to establish a Rhodes-Livingstone Institute of Central African Studies, published in African Affairs 36, no. 145 (1939): 531-32. 
syncretistic in the positive sense of implanting itself into a native cosmology, with local populations determining the terms of its assimilation. ${ }^{73}$ In the latter manner, Thornton argues, "Christianity conquered Kongo peacefully—but at the cost of adapting itself almost wholly to the 'conquered' people's conception of religion and cosmology."74 Even if to a lesser degree, this conclusion could be extended to other parts of south central Africa that were evangelized by the Jesuits. Livingstone himself noted that "the natives are not absolutely anxious to receive the Gospel, [but] they are open to Christian influences."75 As mentioned earlier, he actually observed elements of Christianity that native Africans had chosen to preserve, including histories of saints and relics, but, bearing a more exclusive concept of the faith, he would not acknowledge them to be validly Christian and, hence, religious legacies left behind by the Jesuits. As Thornton would argue, the apparent disappearance of Christianity from south central Africa in the nineteenth century, which Livingstone lamented, was not due to a lack of conversions of native Africans, a resurgence of their suppressed religion, or a failure on the part of those who preached the Gospel to them; rather, "it was caused by a changing definition among European clergy (including Rome) as to what constituted Christianity, coupled with more chauvinistic attitudes towards non-Western (and especially colonial) peoples that arose after $1850 .{ }^{.76}$ With his own exclusive concept of Protestant Christianity shrouded in an essentially European civilization that he also sought to promote, Livingstone could hardly recognize elements of inclusive Catholic Christianity that were sustained in African cosmology, let alone see a Christian in Sechele who kept his "dismissed" wives company beyond his own baptism.

\section{Bibliography}

Alden, Dauril. The Making of an Enterprise: The Society of Jesus in Portugal, Its Empire, and Beyond, 1540-1750. Stanford: Stanford University Press, 1996.

Baur, John. 2000 Years of Christianity in Africa: An African Church History. 2nd ed. Nairobi: Paulines Publications Africa, 2009.

73 See John Thornton, "The Development of an African Catholic Church in the Kingdom of Kongo, 1491-1750," Journal of African History 25, no. 2 (1984): 147-67, here 152; see also Thornton, "Conquest and Theology," 246. In the latter article, the author speaks about "open" and "closed" versions of Christianity rather than "inclusive" and "exclusive" concepts of Christianity.

74 Thornton, "Catholic Church in Kongo," 154.

75 Livingstone, Livingstone and Cambridge, 14.

76 Thornton, “Catholic Church in Kongo," 148. 
Bellachew, Bayetta. "A Brief Account of Coffee Production in Angola: A Quick Assessment." Travel Report no. 11, Inter Africa Coffee Organization \& African Coffee Research Network (June 2015). http://www.iaco-oiac.org/sites/default/files/travel_ report_no_11_-_angola_o.pdf (accessed May 29, 2017).

Birkinshaw, Philip. The Livingstone Touch. London: Macdonald, 1973.

Cabaco, Emanuel et al. As Igrejas monumentos de Angola: Exposição fotográfica. Luanda: Festival Nacional de Cultura de Angola and Instituto Nacional do Património Cultural, 2014.

Calvin, John. A Treatise on Relics. Translated by Valerian Krasinski. 2nd ed. Edinburgh: Johnstone, Hunter \& Co., 1870.

Clark, Shanet. "Dr. David Livingstone: Cultural Approaches to an Important Victorian Figure.” Education Forum, 2005. http://educationforum.ipbhost.com/index.php?/ topic/3895-dr-david-livingstone/ (accessed May 29, 2017).

Duffy, James. Portugal in Africa. Harmondsworth: Penguin, 1962.

Egerton, F. [Frederick] Clement C. Angola in Perspective: Endeavour and Achievement in Portuguese West Africa. London: Routledge \& Kegan Paul, 1957.

Henderson, Willie. "Livingstone, David." In Dictionary of African Biography, edited by Emmanuel K. Akyeampong and Henry Louis Gates Jr., 3: 510-12. 6 vols. Oxford: Oxford University Press, 2012.

Jeal, Tim. Livingstone. London: Pimlico, 1993.

Judd, Denis. Empire: The British Imperial Experience from 1765 to the Present. London: HarperCollins, 1996.

K. "On the Character of Jesuit Missionary Teaching." Church Missionary Intelligencer and Record (July 1886): 529-44.

Law, Robin, ed. From Slave Trade to Legitimate Commerce: The Commercial Transition in Nineteenth-Century West Africa. Cambridge: Cambridge University Press, 1995.

Livingstone, David. David Livingstone and Cambridge: A Record of Three Meetings in the Senate House. London: Universities Mission to Central Africa, 1908.

Livingstone, David. Missionary Travels and Researches in South Africa: Including a Sketch of Sixteen Years' Residence in the Interior of Africa. London: Ward, Lock \& Co., 1857 .

Livingstone, David, and Charles Livingstone. Narrative of an Expedition to the Zambesi and Its Tributaries; And of the Discovery of the Lakes Shirwa and Nyassa, 1858-1864. London: John Murray, 1865.

Martin, A.D. [Arthur David]. Doctor Vanderkemp. London: Livingstone Press, 1931.

Moffat, Robert. Missionary Labours and Scenes in Southern Africa. London: John Snow, 1842.

Moir, Fred L.M. After Livingstone: An African Trade Romance. London: Hodder and Stoughton, 1924.

Newitt, Malyn D.D. Portuguese Settlement on the Zambesi. London: Longman, 1973. 
Rea, William Francis. "Agony on the Zambezi: The First Christian Mission to Southern Africa and Its Failure, 1580-1759." Zambezia 1, no. 2 (1970): 46-53.

Rea, William Francis. The Economics of the Zambezi Missions 1580-1759. Rome: IHSI, 1976.

Rushing, Erin. "David Livingstone and the Other Slave Trade, Part I." Smithsonian Libraries, 2013. https://blog.library.si.edu/2013/og/david-livingstone-and-the-other -slave-trade-part-i/\#.WCm98fl95PY (accessed May 29, 2017).

Schapera, Isaac, ed. David Livingstone: Family Letters 1841-1856. 2 vols. London: Chatto \& Windus, 1959.

Seleti, Yonah. "Finance Capital and the Coffee Industry of Angola 1867-1895." Transafrican Journal of History 16 (1987): 63-77.

Simmons, Jack. Livingstone and Africa. London: English Universities Press, 1955.

Tavard, Georges. Protestantism. Translated by Rachel Attwater. New York: Hawthorn Books, 1959.

Thornton, John K. "Conquest and Theology: The Jesuits in Angola, 1548-1650." Journal of Jesuit Studies 1, no. 1 (2014): 245-59.

Thornton, John K. "The Development of an African Catholic Church in the Kingdom of Kongo, 1491-1750." Journal of African History 25, no. 2 (1984): 147-67.

Wallis, J.P.R. [John Peter Richard], ed. The Zambezi Expedition of David Livingstone 1858-1863. 2 vols. London: Chatto \& Windus, 1956.

Werner, Ronald, William Anderson, and Andrew Wheeler. Day of Devastation, Day of Contentment: The History of the Sudanese Church across 2000 Years. Nairobi: Paulines Publications Africa, 2000.

Williams, Basil. Cecil Rhodes. London: Constable, 1938. 
Robert Aleksander Maryks and Festo Mkenda, S.J. - 978-90-04-34715-1 Downloaded from Brill.come4/26/2023 02:06:52PM via free access 


\section{PART 3}

\section{Encounters in Southern Africa}


Robert Aleksander Maryks and Festo Mkenda, S.J. - 978-90-04-34715-1 Downloaded from Brill.come4/26/2023 02:06:52PM via free access 


\title{
Jesuits and Protestants in South Africa, 1685-2015
}

\author{
Anthony Egan, s.J.
}

\section{Introduction: Snapshots that Suggest a Pattern}

The problem with writing history is that sometimes sources are absent; the history may be "hidden" and unrecorded; or it may not have happened. This is the problem I confront in writing this history of the Jesuit encounter with Protestants in South Africa. There are few sources available that fit the topic, or at least the sources are fragmentary: a text here, a letter in an unrelated archive, snippets of obituaries written without a project such as this in mind. This suggests that Jesuit ecumenism went unrecorded - a "hidden" history not so much the result of intention as oversight. It may be that it was either so commonplace as to be considered not worthy of record, or indeed that it did not actually happen much.

That this chapter exists is a sign that at some level Jesuit-Protestant encounter did occur. The historical retrieval I have done is more a collection of snapshots than a coherent documentary. And, like snapshots, what emerges is a succession of moments and individuals rather than something by which one can make generalizations, establish patterns of practice that suggest a collective process, let alone such a thing as an ecumenical policy.

But a historian must try to make coherence with what she or he has, even if what emerges is more overtly a "fiction" (in the sense of a constructed narrative) than might be desired by those who would prefer history to be an accurate record rooted in an interpretive framework. ${ }^{1}$ Yet even a loose collection of snapshots from the past deserves some kind of interpretation: the very act of writing is inevitably interpretation. To add to this complexity, the author has himself been a participant-observer of at least the last twenty-six years

1 For the debate over the adequacy of my claim, see: E.H. Carr, What Is History? (Harmondsworth: Penguin, 1961); Geoffrey R. Elton, The Practice of History (London: Fontana, 1969 [1967]); Arthur Marwick, The Nature of History, 3rd ed. (London: Macmillan, 1989); John Tosh, The Pursuit of History, 2nd ed. (London: Longmans, 1991); Keith Jenkins, On What Is History? From Carr and Elton to Rorty and White (London: Routledge, 1995). 
in the history he records, reflecting on experience from within the events described.

My chapter thus rests on this premise: despite the limitation of evidence, a picture can emerge of Jesuit encounter with Protestants in South Africa. Although not a central task of Jesuits, we can see a slow if incidental developing encounter-from hostility to a modicum of cooperation - that mirrors both evolving ecumenical sensibilities within the Society (and within the author, truth be told) over the last three hundred-odd years and a shift in Catholic and Protestant regard for the mutual religious other.

Finally, it may even be said that the "format" of this chapter, and the tenuous conclusions that I make, reflect a challenge to Jesuits in South Africa to be more historically conscious, more disciplined in recording our history, more aware of our historical situatedness, even if it means added work in keeping hold of the historical record.

\section{First Contact: Fr. Guy Tachard at the Cape, 1685}

The first Jesuit encounter with Protestants in South Africa occurred literally en route to Siam in $1685 .^{2}$ A French diplomatic embassy to Siam, including a number of Jesuit scientists affiliated to France's Royal Academy, ${ }^{3}$ stopped in at the Cape of Good Hope for a few days to pick up supplies. The Cape had been colonized by the Dutch, specifically the Dutch East India Company, in 1652 as part of their policy — shared by other European mercantilist powers-of setting up refreshment stations along trade routes to the Far East.

The Jesuits, led by Guy Tachard (1651-1712), combined a rest from the rigors of the voyage (none were seafarers) with scientific research and observations of the Cape's flora and fauna. Their encounters as clergy with the otherwise courteous and welcoming Calvinist Dutch authorities highlight the tensions between Catholic and Protestant Europeans at a time when the Thirty Years'

2 For a historian covering roughly four hundred years, the geographical entity "South Africa" is problematic. Present-day South Africa only came into existence in 1910. From 1652 until 1910, South Africa was an expanding piece of southern Africa under first Dutch, then British and Boer rule that would ultimately include the present-day states of South Africa, Lesotho, Botswana, Swaziland, Zimbabwe, and Zambia.

3 See Guy Tachard, A Relation of the Voyage to Siam: Performed by Six Jesuits Sent by the French King, to the Indies and China in the Year 1685 (Bangkok: White Orchid Press, 1981 [1688]), $43^{-80}$. 
War (1618-48), the vicissitudes of the Huguenots in France, ${ }^{4}$ and the Dutch War of Independence $(1568-1648)^{5}$ were recent memories.

These conflicts had led to a hardened and intolerant attitude to religion among the otherwise enlightened Dutch (as had happened among their Catholic rivals). The public expression of Catholicism at the Cape of Good Hope was prohibited. No Catholic churches were permitted; nor were Catholic priests allowed to stay at the Cape. This practice was to continue, apart from a brief interregnum in the early 1800 s, until a few decades after the British occupation of the colony in $1806 .{ }^{6}$ Tachard would note this in his book with some sadness.

Setting forth from Brest, laden with the latest scientific equipment to perform astronomical and geographical research-a gift from King Louis XIv's (r.1643-1715) Royal Academy - the Jesuits and their diplomatic companions traveled the long and difficult route down the Atlantic, sighting the Cape on May 21, 1685, which was Ascension Day. They were relieved. As Tachard recounts:

After we had said our usual Prayers and sung Mass to thank God for the good success of our Voyage; we viewed the Land with our Glasses, and saw it distinctly, not being above three Leagues off. How Barbarous and Barren soever it seemed to be to us, it was nevertheless a delightful sight for Men who had seen no Land from the Canary Islands, which we sailed by the thirteenth of March. ${ }^{7}$

Their delight was temporarily dampened by the Cape weather: becalmed outside the harbor and then tossed by strong winds, they had to remain on their ship until the next morning. Following the usual protocols, the French ambassador and the Jesuits went to visit the governor of the Cape, Simon van der Stel (1639-1712), and the visiting Company commissary general, Hendrik Adriaan van Rheede (1636-91). The latter Tachard described as

4 Louis XIV would revoke the Edict of Nantes (1598), tolerating them in France, a few months after Tachard and company visited the Cape.

5 Jonathan I. Israel, The Dutch Republic: Its Rise, Greatness, and Fall 1477-1806 (Oxford: Clarendon Press, 1998); Geoffrey Parker, The Dutch Revolt (Harmondsworth: Penguin, 1977); Pieter Geyl, The Revolt of the Netherlands 1555-16o9 (New York: Barnes \& Noble, 1966).

6 Catholic Emancipation in Britain came mainly with the 1829 Roman Catholic Relief Act. By 1832, the Catholic Church had established itself in southern Africa. The first bishop of this new vicariate, Patrick Raymond Griffiths, O.P. (an Irishman), served a territory covering what is today the Western, Northern, and Eastern Cape provinces.

7 Tachard, Voyage, 40-41. 
a Man of Quality about fifty years of age, Handsome, Civil, Wise and Learned, and who thinks and speaks well on all Subjects; we were extreamly [sic] surprised to meet with so much Politeness at the Cape of Good-hope [sic], and much more at the Civilities and many Testimonies of Friendship which we received at the first Interview. ${ }^{8}$

The Jesuits were delighted to find that they were allowed to spend some time at the Cape "taking in a little Air and Land." In return for the hospitality, they volunteered in the days that followed to do some scientific research to the benefit of the Dutch, calculating the settlement's longitude with their state of the art equipment - the first time it was ever accurately calculated. ${ }^{9}$ Tachard describes in detail how these measurements were calculated, displaying barely hidden delight in the use of the instruments they had brought with them from France. The Jesuits also spent nights studying the stars of the southern hemisphere. A small observatory was put at their disposal for that purpose.

They were also taken to see the Company garden, which Tachard notes as "one of the loveliest and most curious Gardens that ever I saw, in a Country that looks to be one of the most dismal and barren Places in the World."10 Overall, they were impressed by the fact that what had started so small had grown so rapidly: "[The Dutch] have at present a great Town and a Fort with five Bastions which commands all the Road. The air is very good, the Soil excellent, and Corn grows there as well as in Europe; they have planted Vines which yield a most delicate Wine."11

While the Jesuits did their research, the French crew went hunting, returning with a cornucopia of wild game. Ever the explorer-scientist, Tachard recounts stories told second hand of hunting and of the marvelous wild beasts to be found inland. He also wrote of the people he encountered at the Cape: Dutch colonists and "Natives." Of the latter, he dwells on the Khoikhoi peoples, which he names by the common colonial parlance of Hottentots. His view of them is typical of the era, seeing them as "being perswaded [sic] that there is no other life after this, labour[ing] as little and tak[ing] as much ease as they can in this World,"12 and who in turn viewed the Dutch work ethic as self-imposed slavery

\footnotetext{
8 Ibid., $48-49$.

9 Ibid., 49, 50. Significantly, Tachard's calculations were so accurate that they have become the standard measurement to this day.

$10 \quad$ Ibid., 51.

11 Ibid., 64.

12 Ibid., 69. Here, Tachard is quite simply wrong. The Khoikhoi and San peoples had-and have-a complex religious system that incorporates a number of gods, good and evil, as
} 
and their living in houses and forts as cowardly. Culturally, Tachard viewed the Khoikhoi as living a "wretched" life, though he notes:

Barbarity has not so totally effaced all the Tracts of Humanity in those People, but that there remains still some footsteps of Virtue: they are trusty, and the Dutch allow them free access into their houses without any fear of being Robbed by them [...]. They are beneficent and helpful, and keep nothing wholly for themselves. ${ }^{13}$

Tachard the colonial ethnographer is more complimentary about the Griquas and Namaquas, who lived farther inland, though once again his tendency is to emphasize the "exotic" and their difference from the European colonists. While recognizing that they were "neither Cruel nor Wild, and want neither Docility nor Wit," he suggests that their greatest misfortune was that they "have no Knowledg [sic] of the true God, and that nobody endeavours to instruct them." 14

While once again a view that places Tachard firmly within the category of a man/missionary of his age, this comment hints at his unease about a worrying aspect of the behavior of their Dutch hosts: their attitude to religion. Though the Company had diligently provided ministers to serve the colonists, and had initially organized the Reformed church even without clergy as part of a political committee at the Cape, at the time of Tachard's visit this had not extended to evangelization outside the community. The occasional Khoikhoi or slave had converted and been received into the church, but the missionary era was a thing of the future. Tachard, with limited knowledge of these contexts, would have seen this lack of evangelization as a sign of indifference-and, for Catholics, a great opportunity closed to them by the anti-Catholic laws in force at the Cape.

well as the transmigration of souls. See, for example, David Lewis-Williams and David Pearce, San Spirituality: Roots, Expression and Social Consequences (Walnut Creek, CA: AltaMira Press, 2004).

13 Tachard, Voyage, 71.

14 Ibid., 78, 79. In the decades and centuries that would follow, this lack of evangelization would be rectified, with results that would be the subject of deep political debate. Critics of the process would say that this would destroy the structures of indigenous communities; defenders would argue that "Westernizing" African peoples would build the foundations of liberation movements; and pious people would argue that it would save their souls. Whatever the case, by the return of the Jesuits in the 1870s, most parts of Britishcontrolled South Africa at least had been thoroughly penetrated by Protestant missions of one form or another. 
The greatest source of tension for these first Jesuits in South Africa was the absolute prohibition on being allowed to minister at the Cape of Good Hope, where they discovered that many of the Company's employees were in fact Catholics. Tachard recalls:

No sooner had we got possession of our little Observatory, but the Catholicks $[s i c][\ldots]$ who are pretty numerous, had notice of it and were thereat exceedingly rejoyced $[s i c]$. In the Mornings and Evenings they came privately to us. There were some of all Countries, and of all Conditions, Free, Slaves, French, Germans, Portuguese, Spaniards, Flemings and Italians. They who could no otherwise express themselves; because we understood not their Language, fell upon their Knees and kissed our hands. They pulled Chaplets and Medals out of their Bosoms to show that they were Catholicks, they wept and smote their Breasts. That Language of the Heart much more touching than words, wrought great Compassion in us, and obliged us to embrace those poor People, whom Christian Charity made us look upon as our Brethren. ${ }^{15}$

The Jesuits were, however, all too aware of the delicacy of the situation. They were guests of the Dutch and under Dutch law while on land. The administration of any sacrament was prohibited. Tachard and his companions could celebrate the sacraments on board ship since that was French territory-but locals were forbidden to join them there. To break the law would not only jeopardize their research and possibly court arrest or deportation; it would have been tantamount to causing a diplomatic incident. The Jesuits, it seems, abided by the laws of their hosts, while quietly exhorting their fellow Catholics to remain true to their faith as best they could.

When Tachard and his confrères sailed from the Cape a few days after landing, the Jesuit presence in what is now South Africa ended for almost two centuries. Jesuits on the way to Asia no doubt stopped off for supplies in the decades that followed, but their engagement with southern African society under Dutch and later British rule came to an end. The "anti-ecumenism" of the era made interaction between Jesuits and Protestants impossible.

\section{Missionaries and Schoolteachers (1870s-196os)}

Almost two hundred years passed before the Jesuits established an actual base in South Africa. In that interregnum, the Society was suppressed and 
re-established; the new Society was a more cautious creature than it had been, more explicitly Roman in its orientation. ${ }^{16}$ During the 1870 , it was experiencing state hostility throughout Europe, not least in united Italy itself, where the General Curia was temporarily moved to Fiesole, when the idea of a southern African mission was proposed.

In the interim, Catholicism was belatedly being established in southern Africa. ${ }^{17}$ Prohibitions on Catholic religious practice started to ease in the early nineteenth century with the British occupation of the Cape in 1806. Ongoing restrictions continued until Catholic Emancipation in Britain in the late 1820s and early 1830 became a reality. By 1837 , a vicariate of Southern Africa was established in the Cape Colony under its first vicar apostolic, Bishop Patrick Raymond Griffith, O.P. (1798-1862). Since the territory was vast, the vicariate was split into two parts, an eastern and western vicariate. Missionaries, mainly Oblates of Mary Immaculate (o.M.I.), started moving into the hinterland of Natal, the Basutoland protectorate (Lesotho) and the Boer republics of the Transvaal and Orange Free State. They faced considerable obstacles: anti-Catholicism in the republics and everywhere they found long-established Protestant missions.

In the 1870s, James David Ricards (1828-93), the bishop of the eastern vicariate, based in Grahamstown and later Port Elizabeth, approached the Society with a request: to create a Jesuit school, an expansion of a small school already established, in the nearby town of Grahamstown-which already had Anglican and Methodist schools. He saw this as an essential service to the significant numbers of Catholic "sons of colonists" in the area, and as part of a belated effort to exercise Catholic influence in southern Africa.

Ricards gained the ear-and the enthusiasm — of Englishman Alfred Weld, S.J. (1823-90) one of Superior General Peter Jan Beckx's (1795-1887, in office $1853-87$ ) assistants. Weld not only embraced the idea of running a diocesan boys' school in Grahamstown; he also saw it as an opportunity to create a new southern African Jesuit mission. The geographical territory of the Zambesi Mission, as it was called, encompassed the whole of southern Africa, including the future states of South Africa, Botswana, Lesotho, Swaziland, Zimbabwe, Zambia, Malawi, and even western parts of Mozambique not under Portuguese control. Beckx endorsed Ricards's proposal for a school in May 1875 and also agreed to send two Dutch priests to Graaff-Reinet. ${ }^{18}$ With these two projects in mind, the first Jesuits arrived in South Africa in late 1875, taking ownership

16 This section draws heavily on Judy Ann Ryan, "An Examination of the Achievement of the Jesuit Order in South Africa, 1879-1934" (MA thesis, Rhodes University, 1990).

17 See William E. Brown, The Catholic Church in South Africa: From Its Origins to the Present Day, ed. Michael Derrick (London: Burns \& Oates, 1960). 
of the school—St. Aidan's College ${ }^{19}$ —in January 1876 . The Zambesi Mission in southern Africa was established in 1877 and entrusted to the Society's English province in 1879 .

Two streams thus developed in South Africa-education and missionary work. Although the idea was to center it in Grahamstown and St. Aidan's, it soon became apparent-after a number of Jesuits died during their travels northward owing to a lack of familiarity with the climate- that a new center for the mission work was needed: a center that would be a base for expansion (beyond the parishes in Graaff-Reinet and Grahamstown) and a place of formation for young Jesuits joining the Zambesi Mission. At Graaff-Reinet, a novitiate was briefly established in 1887. A number of novices from England and the Netherlands left—one Dutch novice literally leaping over the wall and finding refuge with the local Dutch Reformed minister, who took him in. ${ }^{20}$ According to Jesuit tradition, the ex-novice later became a Reformed clergyman.

The Jesuits then acquired Dunbrody in 1882. Situated on the Sundays River, inland from Port Elizabeth, this former monastery of Trappist monks who had moved to Natal to found the Mariannhill monastery near Durban ${ }^{21}$ became a Jesuit mission station as well as formation center where scholastics would study philosophy, theology, African languages, and complete their tertianship after ordination. ${ }^{22}$ Though the center had forty Jesuits (including twenty-two scholastics) by 1887, persistent droughts and poor conditions led to its closure in 1890 . The mission station itself would struggle on under similar adversities until its closure in 1934 .

From the outset, the Jesuits' primarily focused on the north. Battling severe conditions to which these Europeans were unaccustomed, they persisted in sending men into southern Africa. Small missions and temporary presences in what is now the Northern Cape and Botswana were established and then closed. Their greatest achievement was establishing a permanent mission in what is now Bulawayo, Zimbabwe, which spread across present-day Zimbabwe with the British annexation of the territory. Here, the Jesuits found an unusual ally: empire-builder Cecil John Rhodes (1853-1902), who gave them tracts of land around Salisbury, present-day Harare. As the Zambesi Mission morphed

19 Frank L. Coleman, St Aidan's College (Grahamstown: Rhodes Institute for Social and Economic Research, 1980).

20 Ryan, "Achievement," 66.

21 They would there become missionaries to the Zulu community, and would be formed into the Congregation of Missionaries of Mariannhill (СмM).

22 J. O'Neil, s.J., "Dunbrody Mission after Twenty Years," Zambesi Mission Record (October 1903): $298-305$, here 298 . 
into a mission of the English (later British) province, the Jesuit focus was on Southern Rhodesia. South Africa in effect became a small adjunct of Britain's Salisbury mission. By the 196os, the South African Jesuit footprint was smallSt. Aidan's College (which would close in 1973) and a handful of Jesuits in diverse ministries in Cape Town and Johannesburg.

What, then, of Jesuit relations with Protestants in South Africa during this period (1870s to about 1960)? There is a dearth of material on the subject, but a series of glancing references in the Zambesi Mission Record, the journal of the Mission published in London, suggest an atmosphere of mistrust and at times outright hostility on both sides, occasionally punctuated by warmer expressions of mutual respect. Significantly, these attitudes depended on what part of the South African mission we examine.

If we look at the situation in St. Aidan's, we see an ambivalent but largely cordial relationship. The school existed in Grahamstown, what one Jesuit observer called "practically an English Cathedral-City, having its Anglican Bishop, its Public Schools, and schools or colleges of different denominations, Catholic, Anglican, Wesleyan, all corresponding to flourishing Secondary Schools in England."23

As such, St. Aidan's was an integral part of the colonial culture of Grahamstown. It admitted non-Catholic boys, not least because that guaranteed muchneeded state subsidies, and it also interacted with its Anglican and Methodist counterparts, particularly in sporting events where it had an excellent reputation for boxing. Colonial officials (almost always Protestant) visited the school for prize-giving ceremonies and other civil occasions. During the Boer War (1899-1902) and the World Wars, the school's alumni served with British and later South African forces against Boers and Germans alike. In short, the atmosphere was one of politeness to non-Catholics, but with no apparent expressions of active ecumenism.

On the "missions" - Dunbrody, Keilands, and others - the mood was different. One Jesuit, Charles Bick (1861-1939), saw Keilands for example as "hemmed in on all sides by Protestant missions [...] [who have] anticipated us by forty years." He added: "So this is our task - to rescue these poor blacks from heresy; a task which is arduous and likely to last long, and of which God alone knows what will be the outcome."24

23 Herman Walmesley, S.J., "Some First Impressions of South Africa," Zambesi Mission Record (January 1900): 225-28, here 227.

24 Charles Bick, S.J., "The Missions of Kaffraria," Zambesi Mission Record (May 1898): 27-34, here 27 . 
Bick's views on his black flock, patronizing and racist by modern standards, are intimately connected to his anti-Protestant outlook, which included open contempt for the "facile apostolate of the Wesleyans": ${ }^{25}$

The Ama Roma (the Romans), as we are called, were so different to the foreign preachers they had been wont to see [...]. Imbued with Protestantism, disgusted with the multitude of sects that swarm in their country, the Kaffirs ${ }^{26}$ naturally thought at first that our arrival would have no other result than to increase the number of religious bodies [in the area] [...]. On the other hand, filled with hatred for the white men who have despoiled them of their patrimony, they seemed little disposed to listen to us. ${ }^{27}$

As latecomers to the mission field, something they clearly resented, the Jesuits did indeed struggle to gain and maintain converts, a concern expressed in letters and reports throughout the period until the 1930s. However, their observations on African culture (empirically fascinating though often read through a Eurocentric vision verging on racist ${ }^{28}$ suggest that they did not see this earlier Protestant influence as a primary obstacle to evangelization.

The anti-Protestant outlook is mirrored throughout the period in successive editorials in the Zambesi Mission Record decrying the lack of Catholic support for the missions. Noting the British victory after the Boer War (which the Jesuits had welcomed, possibly as the lesser of two evils compared with the virulent anti-Catholicism of the Afrikaners), one editorial warned of an advance of Anglicanism and "general awakening of the Protestant Sects" in South Africa, pointing out how the "Protestant Church in England" took mission seriously and funded it generously. It argued: "Surely it is not for Catholics to view all these efforts with folded arms - to stand by with indifference while the fields are acquired, the seed sown and the harvest reaped by others!"29 Another warned: "The missionary spirit is strong among English Protestants, and unless

\footnotetext{
25 Ibid., 29.

26 This racist term, originating in the Arabic term kufr ("unbeliever"; i.e., non-Muslim), was common parlance in the nineteenth and early twentieth century, even among more liberal missionaries. It illustrates how what was once seen as a morally neutral descriptor can change its significance. Historical accuracy demands its—however reluctant—inclusion in this text.

27 Bick, "Kaffraria," 28.

28 Once again, one can only say they were men of their times, many of them also only amateur anthropologists.

29 "Editorial," Zambesi Mission Record (October 1903): 283-85, here 284.
} 
we can establish new stations they are sure ere long to take possession of the land, to the exclusion of the Catholic priest." ${ }^{30}$

Perhaps the most dramatic and grandiose statement of this view came from Richard Sykes, S.J. (1854-1920):

Whatever may be said for or against the Imperialistic idea as it affects a kingdom which is merely of this world, there is at all events one realm in which Imperialism well befits, and one people who ought to be Imperialistic - the realm of Christ upon earth and the people who constitute the kingdom, the members of the Catholic Church. ${ }^{31}$

Cumulatively, these statements give us an impression of the general Jesuit attitude of the time. In an age before the great ecumenical opening facilitated by the Second Vatican Council (1962-65), these views need to be seen in context: Jesuits, like most Catholics, believed that the Catholic Church was the one true faith, the sole absolute guarantor of salvation. Add to this the generalized anti-Catholic atmosphere in South Africa at the time, and the long memory of Catholic persecution and discrimination in Britain during the period from the Reformation until at least the mid-nineteenth century (including persecution of Jesuits), and the Jesuit reaction to Protestants becomes understandable.

This should be further qualified. Most Jesuits in South Africa, from at least the 1890 s, were British by birth or descent. They were also, as white people, colonists together with other colonists, sharing all the colonial assumptions (however liberal some might have been) of their non-Catholic peers. The St. Aidan's experience illustrates this. So too did Jesuit attitudes to colonial figures like Rhodes who, though not Catholic nor even particularly religious, actually admired Jesuits and proved to be a major benefactor to the Society's southern African mission. This is expressed in a glowing obituary of Rhodes in 1902. Calling him "a great man [...]; to a large proportion of people in South Africa he was a kind of idol or uncrowned king,"32 the writer claimed he had a great reverence for the Catholic Church, Catholic missionaries in general, and the Society in particular: "The Jesuit Fathers treasure, and will long treasure, the memory of Cecil John Rhodes - for his kindness and generosity, his large-heartedness to them, his sympathy for their work and their aims. He was

\footnotetext{
$30 \quad$ "Editorial," Zambesi Mission Record (April 1906): 43-45, here 44.

31 Richard Sykes, S.J., "A Plea for Imperialism," Zambesi Mission Record (April 1909): 534-37, here 534 .

32 "The Late Cecil John Rhodes," Zambesi Mission Record (July 1902): 95-97, here 95.
} 
their friend, staunch and true [...]."33 Ever pragmatic, the Jesuits in South Africa were willing to embrace some Protestants, albeit those sympathetic to the Society, benefactors of the mission, and of fairly agnostic hue.

\section{Radical Encounters: Fr. George Edmondstone and the University Christian Movement}

The 196os was the decade in which ecumenism, particularly the ecumenical struggle against apartheid, ${ }^{34}$ gained momentum in South Africa. The Second Vatican Council largely opened up official dialogue between Catholics and Protestants in the country, though the practice was fairly restrained apart from the work of two bishops who had been prominent at the council: Archbishop Denis Hurley, O.M.I. (1915-2004) (of Durban) and Bishop Gerard van Velsen, O.P. (1910-96) (of Kroonstad in the Orange Free State province). The Southern African Catholic Bishops' Conference (SACBC) entered into dialogue with individual Protestant churches and with the Christian Council of South Africa, soon renamed the South African Council of Churches (SACC). ${ }^{35}$ Hurley would later form Diakonia, a Durban-based ecumenical group committed to the struggle against apartheid. He was also close to the mainly Protestant Christian Institute, ${ }^{36}$ formed by a dissident Dutch Reformed minister Beyers Naudé (1915-2004). The other vanguard of Catholic ecumenism in the 196os was the Dominicans, who had close relations with the most radical ecumenical group of the era, the University Christian Movement (UCM), through their involvement in the National Catholic Federation of Students (NCFS) as chaplains.

The emergence and active participation of Catholics within the UCM was largely the result of the initiative of NCFS national chaplain, diocesan priest,

33 Ibid., 97 .

34 Documented in John W. de Gruchy, The Church Struggle in South Africa (Cape Town: David Philip, 1979); Daryl M. Balia, Christian Reaction to Apartheid: Ecumenism in South Africa 1960-1987 (Braamfontein: Skotaville Publishers, 1989); Peter Walshe, Church versus State in South Africa: The Case of the Christian Institute (London: Hurst, 1983); Walshe, Prophetic Christianity and the Liberation Movement in South Africa (Pietermaritzburg: Cluster Publications, 1995).

35 For an overview, see Bonaventure Hinwood, "Ecumenism," in The Catholic Church in Contemporary Southern Africa, ed. Joy Brain and Philippe Denis (Pietermaritzburg: Cluster Publications, 1999), 349-85.

36 Walshe, Church versus State; Peter Walshe, "Mission in a Repressive Society: The Christian Institute of Southern Africa," International Bulletin of Missionary Research 5, no. 4 (October 1981): $146-52$. 
and former secretary general of the SACBC Colin B. Collins (b.1931). Collins, together with Basil Moore (a Methodist theologian based at Rhodes University), set up UCM with clear purposes: radical ecumenism and radical student politics. Close to the secular National Union of South African Students (NUSAS), UCM became a hotbed for new ideas: Black Theology (imported from the United States and adapted to the South African context), modern secular Protestant theology, Freirean pedagogies from Latin America, and experimental agape liturgies that included contemporary music, dance, the use of film and psychological encounter groups. It was out of a UCM conference that black students led by Steve Biko (1946-77) developed the philosophy of Black Consciousness and decided to break from NUSAS and form the South African Students' Organization (SASO). ${ }^{37}$

With its core centered in Grahamstown and Rhodes University, it might have been expected that Jesuits would have been drawn to UCM. This was largely not the case. By the mid-196os, there were about thirteen Jesuits in Grahamstown, almost all of them based at St. Aidan's College, the majority Englishmen wary of ecumenism beyond the "tea and sandwiches" ecumenism that had marked the Society's approach in the city since the turn of the century-and not all that politically aware either. It is a myth that the Catholic Church in South Africa was a consistent, let alone radical, opponent of apartheid. The church's unease with political involvement (and with ecumenism) was rooted both in a (largely true) sense that they were "outsiders" in a hostile Calvinist country and in the domination of the institution until the 1970s of an economically powerful racist white lay minority and cautious foreign-born bishops backed by an uneasy Vatican diplomatic presence. ${ }^{38}$ Progressives like Hurley (a South African) and van Velsen (Dutch), the Dominicans and individuals like Collins, fought an ongoing and slow, but eventually successful, battle to change the church's non-confrontational approach. With one major exception, during this early era the Jesuits erred on the side of caution.

37 William John Houston, "A Critical Evaluation of the University Christian Movement as an Ecumenical Mission to Students 1967-1972" (mth thesis, University of South Africa [UNISA], 1997); Ian MacQueen, "Students, Apartheid and the Ecumenical Movement in South Africa 1960-1975," Journal of Southern African Studies 39, no. 2 (2013): 447-63; Clare Elizabeth Ann McKay, "A History of the National Union of South African Students, 1956-1970" (D.Litt. et Phil dissertation, UnISA, 2015), 424-27; Anthony Egan, The Politics of a South African Catholic Student Movement (Cape Town: University of Cape Town Centre for African Studies, 1991), 34-47.

38 Garth Abraham, The Catholic Church and Apartheid: The Response of the Catholic Church in South Africa to the First Decade of National Party Rule, 1948-1957 (Johannesburg: Ravan Press, 1989). 
The exception was George Robert Edmondstone (1916-86), ${ }^{39}$ a South African Jesuit who quit teaching at St. Aidan's College to lecture in the Mathematics Department at Rhodes University in 1959. Ed or Eddie, as he was known in university and church circles, knew Moore and the other Protestant professors on the Divinity Faculty. He got on well with Collins, who by the time of UCM was seen as a maverick in Catholic circles. ${ }^{40}$ Edmondstone was well liked, and though he was primarily a mathematician, he was a voracious reader of theology throughout the 196os until his death in Grahamstown in 1986. He strongly supported Vatican II, developed a strong opposition to apartheid in the 196os, sympathized with the student movement including UCM, and was committed to ecumenism.

Unlike the official Catholic chaplain to Rhodes at the time, Edmondstone was less worried about the experimental liturgies-include agape meals that at times seemed to blur into ecumenical Eucharists-and more sympathetic with UCM's radical politics. In letters exchanged with Collins, Ed noted - with disapproval - that an individual within the University Catholic Society had been trying to force them to break all ties with UCM. ${ }^{41}$

Though Edmondstone was hardly active in UCM, he represented a small bloc of progressive Catholic clergy who supported the organization until its demise in 1973. Evidently, he succeeded in keeping Rhodes Catholic Society within UCM: at an NCFS National Council meeting in July 1968, it was reported that the society's "differences" with UCM had been successfully resolved. ${ }^{42}$

Edmondstone "survived" the dissolution of UCM, the demise of St. Aidan's, and the departure of his confrères from Grahamstown in the early 1970s. He stayed on at Rhodes, even past his retirement from the university, living in a house that belonged to his mother, working as a parish priest in Grahamstown parishes, and deeply involved in setting up welfare projects in the city. Years after his death, members of Rhodes University Divinity Faculty still remembered him with great affection, not least for his encouragement of Protestant

39 "Obituary: Fr George Edmondstone," Letters \& Notices [internal journal of the British Jesuit province] 88, no. 392 (Easter 1987): 299-302.

40 He left the priesthood and the church, moved to Canada where he completed a $\mathrm{PhD}$ in education, and settled as a lecturer in Australia.

41 University of the Witwatersrand, University Christian Movement Papers (AD1126): H5. Fr. "Rob" Edmondstone, s.J., to Fr. C.B. Collins, May 22, 1968; M2: "Rob" to Collins, April 20, 1968.

42 University of the Witwatersrand, University Christian Movement Papers (ADi126) J4: NCFS: Minutes of Council Meetings: July 1968, 18-19. 
scholars to take an interest in post-conciliar Catholic theologians and in Catholic spirituality. ${ }^{43}$

\section{Struggle Ecumenism in the 1980 s}

Though the ecumenical struggle against apartheid emerged in the late $1960 \mathrm{~s}$ and 1970s, Jesuit involvement tended to be quite muted. ${ }^{44}$ Until the late 1970s, the Jesuits in South Africa were managed from Rhodesia, which was itself going through a war of liberation in which the Society frequently found itself on opposite sides. When the vice province, later province, of Zimbabwe was created in 1979, the handful of South African Jesuits found themselves once again a mission of the British province. By the mid- to late 1980 , it would become a dependent region of the British province, a situation that continued until 2016 when its affiliation reverted to the (new) Zimbabwe-Mozambique province. The focus of South African Jesuits during the 1980 os rested in parishes in Johannesburg and Cape Town, university chaplaincies, and increasingly Catholic seminaries.

The new contexts combined a focus on intra-Catholic works with a public engagement that was more overtly ecumenical. The ecumenism tended to focus on political issues. With the active engagement of Catholic students in ecumenical protest - most notably for its mainly white constituents in anticonscription movements-chaplains found themselves almost by default in these activities. Jesuit chaplains often found themselves caught in the middle-between campus protesters (including many from the Catholic student movement) and riot police. One Jesuit, David Rowan (b.1952), was even hit by a rubber bullet on Wits campus on one occasion. ${ }^{45}$ Parishes like Holy Trinity in Braamfontein, Johannesburg, literally on the edge of the main campus of the University of the Witwatersrand, and Kolbe House-the chaplaincy to the University of Cape Town-became places where student groups (religious and non-religious) would meet and where students would sometimes hide when chased by riot police during demonstrations.

During the great protest marches near the end of the 1980s, as the regime was slowly collapsing, Jesuit chaplains joined their students in great marches.

43 Author's conversations with Divinity School professors, particularly Felicity Edwards, c. 1990 and 1996.

44 Much of this narrative is based on the author's experience. I got to know the Society as a student at the University of Cape Town in 1985 and joined the Jesuits as a novice in 1990.

45 Conversations with David Rowan, s.J., on various occasions. 
Usually, these were ecumenical affairs: Catholics and Anglicans tended to stick together, sometimes accompanied by Methodists and Jews and students of no fixed religious abode. UCT chaplain Graham Pugin (b.1957) was tear-gassed a few times with them, and sprayed with purple dye once. Pugin was also closely involved in supporting Christian youth contemplating refusing to serve as conscripts in the South African Defense Force, having himself been a conscientious objector during the 1970 s.

Outside the student movement, Jesuits were involved in the ecumenical struggle in other ways. During the late 1980s, the community in Belgravia, Johannesburg, hid SACC leader and Pentecostal pastor Frank Chikane (b.1951), whom the security police wanted to detain without trial. Jesuit school teacher David Dryden (b.1941) also smuggled Chikane into South Africa from Botswana after Chikane had attended an ecumenical meeting outside the country. ${ }^{46}$ Dryden cannot recall the exact date of this event, but in his autobiography Chikane notes that he had been in Europe in March-April 1986 and in Europe, Canada, and North America between September 1986 and March 1987, where he had addressed the second general assembly of the Ecumenical Association of Third World Theologians (ЕAтWOT) ${ }^{47}$

In Orlando West, Soweto, Xolile Keteyi (1952-94) quietly supported and encouraged youth activists in his parish, creating spaces for youth to meet and organize, as part of a wider renewal of his parish youth. ${ }^{48}$ One or two of these youth who would later join the Society would comment that Keteyi made no distinction between Catholics and non-Catholics - they were Christian youth involved in the struggle. ${ }^{49}$ Though he kept a low political profile, Keteyi was also part of the ecumenical group that developed and wrote the 1985 Kairos Document. ${ }^{50}$ He was its only Jesuit signatory, though many others shared its sentiment, wholly or in part. This was a landmark ecumenical statement from the religious grassroots that called for religious resistance to apartheid. Keteyi's vision was strongly ecumenical by default: his primary concern was for a Christianity fully inculturated into the African context. His sole book, published posthumously, barely refers to the Catholic Church as such, except to

46 Conversations with David Dryden, s.J., Johannesburg, most recently September 26, 2016.

47 Frank Chikane, No Life of My Own: An Autobiography (London: Catholic Institute for International Relations, 1988), 111.

48 “Obituary: Fr Xolile Keteyi," Letters \& Notices 92 (Christmas 1994): 151-63, here 159.

49 Comments of Rampe Hlobo, S.J., on various occasions. Similar remarks were made to me by former Jesuit Jeff Xaba.

$50 \quad$ Challenge to the Church: The Kairos Document (Braamfontein: Institute for Contextual Theology, 1985). 
commend existing efforts to inculturate and to stress a notion of Catholicity as unity in diversity rather than a Euro-centric ecclesiology. ${ }^{51}$

The oldest Jesuit "activist" during this period was Gerard Lorriman (1915-2011), based in Cape Town. ${ }^{52}$ A veteran of the Second World War, and a surgeon who was widowed in his fifties before joining the Society, Lorriman came to South Africa to work as a hospital chaplain. He also worked as Catholic chaplain to Robben Island prison, where he presided over ecumenical Bible study groups that included luminaries like Nelson Mandela (1918-2013) and Tokyo Sexwale (b.1953). Having been banned from the island when the state guessed he was ferrying messages from prisoners to their lawyers, Lorriman worked in the townships of the Cape Flats-a task in the mid-1980s that included presiding over many political funerals of activists killed during protests. These were always ecumenical and interfaith affairs that were as much political rallies - some of them barely hidden occasions for the banned African National Congress to, literally, unfurl their colors. Many pastors found these events - which frequently ended in confrontations with army or riot police, teargas and bullets-terrifying and avoided them. Lorriman did not, burying folk of every religious persuasion and none. On one occasion, he faced down two armored police vehicles, striding out in front of them and forcing them to back off. The photograph of this event went around the world, becoming an iconic image of the times.

Similarly, in the early 1990s, in Elandskop, a semi-rural parish near Pietermaritzburg, Natal, Father Tim Smith (b.1952) found himself caught in a war between pro-ANC and pro-Inkatha factions. ${ }^{53}$ These conflicts and the responses to them spanned religious boundaries-Inkatha and ANC supporters were members of his parish, which was split down the middle. (The same was true for all Christian churches in the area.) When Smith became one of a group of ecumenical clergy and laity documenting and reporting atrocities in the

$5^{1} \quad$ Xolile Keteyi, Inculturation as a Strategy for Liberation (Pietermaritzburg: Cluster Publications, 1998).

$5^{2}$ This is based on numerous conversations with Lorriman over a number of years. See also: Gerard Lorriman, "Report from the Western Cape," Letters \& Notices (Summer 1994): 16-26; "Obituary: Fr Gerard Lorriman," Letters \& Notices (Autumn 2011): 367-77.

53 This was the so-called "Seven-Day War." See Matthew Kentridge, An Unofficial War: Inside the Conflict in Pietermaritzburg (Cape Town: David Philip, 1990). Inkatha emerged as a domestic liberation movement in what is now KwaZulu Natal in the 1970s. Originally close to the African National Congress, by the mid-1980s it was the sworn enemy of the ANC and its internal allies, culminating in violent conflict between it and anc-aligned organizations. 
area, ${ }^{54}$ he was targeted for assassination. He discovered his status while filling up petrol at a garage: one of the attendants told a colleague that Tim had a price on his head. Tim understood Zulu, the language they spoke. When he reported this to his regional superior in Johannesburg, he was quickly moved to Johannesburg. His Jesuit replacement, Chris Chatteris (b.1950), carried on Smith's work, however.

This kind of low-level "struggle ecumenism" was practiced by many of the Jesuits until the democratic elections of 1994. Fragmented and ad hoc in nature, there was no formal Jesuit "plan" by which it was carried out, no specific organization under whose auspices the Jesuits worked. The politically charged context of the time meant that, for the Jesuits, as for many Catholics engaged in the anti-apartheid struggle, the situation determined the ecumenism. There were no overt dialogues with Protestants over points of theology, apart from the ways in which the contextual theology of struggle might be implemented. But what this did ultimately achieve was the building of personal relationships across confessional and religious divides. Having marched with a particular Methodist pastor, debated theology with a progressive Dutch Reformed domi$n e e$, advised and received advice from a particular Anglican priest or bishop, it was increasingly difficult to see them in purely oppositional terms. While Vatican II may have opened up the idea of dialogue, for many Jesuits the struggle era caused us to start reconfiguring our notion of "church."

\section{Spiritual Crossovers: Vuselela, the Jesuit Institute, and the Spread of Ignatian Spirituality in Post-apartheid South Africa ${ }^{55}$}

In the wake of the 1994 democratic transition in South Africa, church engagement in public life - and in ecumenical political activity-declined. The reasons for the former were threefold: first, many of the older religious activists retired or died; second, a number of younger activists left their work in the church for politics; third, the churches as a whole seemed to breathe a sigh of relief and withdrew from the public square, arguing that now the aberration of apartheid was over they could get back to the "real" business of saving souls.

54 Tim Smith, They Are Killing Our Children (Pietermaritzburg: Pietermaritzburg Agency for Christian Social Awareness, 1990).

55 The author was a direct participant in many of these events. In this section, I draw on numerous conversations with its other participants: Annemarie Paulin-Campbell, Frances Correia, Puleng Matsaneng, Graham Pugin, s.J., Russell Pollitt, s.J., David Smolira, S.J., Raymond Perrier, Peter Knox, S.J., and James Fitzsimons, s.J. 
The once strong SACC also went into decline, ironically just as the Catholic Church shifted from being an observer to full member in the body.

Having enjoyed a growth period in vocations in the late 1980s, the Society of Jesus had its own crisis: over a period of roughly two years (1992-94) it lost four of its younger members - a newly ordained priest, two deacons, and a brother. While the works it had done in seminaries, parishes, and chaplaincies in the 1980 s mainly continued - apart from its withdrawal from Elandskop and a Johannesburg parish - ecumenism remained low key and ad hoc: Jesuit seminary professors like Nicholas King (b.1947) and Ed Dougherty (b.1941) worked individually with Protestant counterparts at the university in Pietermaritzburg and the neighboring "cluster" of seminaries; university chaplains always found among their charges a handful of non-Catholics (usually Anglicans, sometimes Methodists and Lutherans) who for whatever reason found themselves more at home in the Catholic chaplaincy than in Protestant counterparts. ${ }^{56}$ It would be out of the chaplaincies-in particular, a group of students supported by Jesuits working at the University of the Witwatersrand - that a new project would emerge that would carry Jesuit presence through Ignatian spirituality to a wider Protestant community than ever before.

As South Africa entered the Mandela era-the era of the Truth and Reconciliation Commission (TRC), and Mandela's broader efforts to reconcile a still-divided country - interest in spirituality grew. Among former activists, some exhausted by the struggle, the sense arose of the need for more personal, inner work. Reconciliation, too, played a part in this. The TRC, led by Archbishop Desmond Tutu (b.1931), has often been criticized for being too close to a spiritual revival than a commission to investigate the crimes of the apartheid era. True as this may be, the nature of the exercise-story-telling and the (all too few) attempts to reconcile victim and victimizer-lent itself to the practice of prayerful reflection. An ecumenical group from Britain, called the Llysfasi Group, led by British Jesuit writer and spiritual director Gerard W. Hughes (1924-2014), came to South Africa a number of times to give the Llysfasi Workshops. These were ecumenical projects that engaged mainly with Catholics, Anglicans, Methodists, and Lutherans. A few Jesuit scholastics participated in them, but their impact was felt mainly among Protestants. Though

$5^{6}$ During this period, many mainline Protestant churches cut back on their university chaplaincies. Non-denominational evangelical and Pentecostal movements on campus (like His People, Students Christian Association) absorbed many of them, but someparticularly those that had a more "high" ecclesiology or were uneasy with the ambivalent political legacy these evangelical groups brought with them from the apartheid era-felt more at home with the Catholics. 
this Protestant Ignatian network grew, many of its members had very limited knowledge of its Catholic and Jesuit roots. ${ }^{57}$

Over the new year of 1996, a small group of Catholic laywomen-students and former students of the University of the Witwatersrand-gathered for a discernment retreat ending on the feast of the Epiphany. Some had been contemplating the religious life; others were looking to find a way of life that would combine service to God with contributing to social reconciliation. Under guidance of Jesuit university chaplains, notably Rowan and Pugin, they had made, were making, or would subsequently make, the nineteenth annotation of the Spiritual Exercises. They became the core of an informal "Epiphany Group" that would form a lay-run, Jesuit-guided and supported center for Ignatian spirituality.

Annemarie Paulin-Campbell (b.1971) (a psychologist) and Frances Correia (neé Dormehl) (b.1974) (a student of comparative literature) subsequently pursued further studies in spirituality - the former completing both a master's degree in Christian spirituality at Heythrop College, University of London, and the three-month program in the Spiritual Exercises at St. Beuno's, Wales; the latter making the Exercises and completing an internship with the Grail Movement in Britain. On their return, they started Vuselela, later called the Center for Ignatian Spirituality (CIS), in Johannesburg. Funded by the Society, a number of Jesuits also assisted the center in its work-initially giving parish-based weeks of guided prayer. They were soon joined by another laywoman, Puleng Matsaneng (b.1969) — a member of the Jesuit parish in Orlando West, Soweto. From the outset, too, a number of Jesuits assisted them where they could with these exercises.

Initially, the work they did gained greatest traction among Protestant congregations. It seemed that, as they observed, their work resonated most with Methodists, Baptists, and Anglicans, who seemed less nonplussed by a ministry done by laypeople and women than most Catholics. ${ }^{58}$ What did spook some Protestants, particularly clergy, however, was the underlying Catholicity of some dimensions of the Exercises.

To allay such fears, some sophisticated theology was needed. Jesuits helped out here, and became key members of the center as it expanded from giving retreats of various kinds to training people in spiritual accompaniment and (having first made the Exercises) giving the Exercises. A retired Jesuit priest, James Fitzsimons (1919-2015), himself a long-standing spiritual director of Spirituality 104 (2003): 38 . 
note, ${ }^{59}$ became a crucial part of this process. He developed and taught a theology of the Spiritual Exercises that kept the Exercises faithful to their sources while being, as he put it, "mildly ecumenical." ${ }^{00}$ It may have been "mildly ecumenical" to him, but that it was completely in keeping with mainstream Catholic understandings of the Exercises allayed many fears and uncertainties among non-Catholic participants.

Framed by a theology of grace that echoed (perhaps even anticipated $)^{61}$ the 1999 Joint Catholic-Lutheran Declaration on Justification by Faith, Fitzsimons drew heavily on Gilles Cusson's biblical theology of the Exercises, ${ }^{62}$ on theologians like Karl Rahner (1904-84), on the classical contemporary commentators on the Exercises, and on his years of experience as a spiritual director. Through his contribution, the team were able to present a theology of the Exercises true to its origins but sufficiently adaptable to engage with Protestant sensibilities. Thus, exercises like "Rules for Thinking with the Church" could be read in both a Catholic-papalist and a more Protestant way.

Fitzsimons even had a way of adapting the Marian dimensions of the Exercises to allay Protestant fears of "Mariolatry." Noting that Ignatius had found this in Ludolph of Saxony's (c.1295-1378) Life of Christ (which many say was possibly the source he used at Manresa), he interprets the (non-scriptural) resurrection appearance of Jesus to Mary thus:

He comes to his Mother as the one who has been closest to him, of course [from a Catholic perspective], but in coming to her, he is coming as its Saviour to all the Creation which she represents, to each of us who, like her, share in that glory, that life in the Spirit for which we were made

59 A measure of this work is that, by the end of his life (2014), having retired from teaching in the spirituality training programs and past ninety years old, he was still seeing a number of individuals for spiritual direction.

6o James Fitzsimons, S.J., "Notes for a Theology of the Spiritual Exercises of Saint Ignatius" [unpublished manuscript still used in various forms by the Jesuit Institute South Africa, n.d.], 3 .

61 I am vague in this regard because Fitzsimons's text is not dated. He does not refer to the Joint Declaration, nor to Hans Küng, whose thought was seminal (though for political reasons uncredited) to the declaration. Neither Annemarie Paulin-Campbell nor Frances Correia, when I asked them, could specify a date when Fitz joined them in the training program - though they sensed it was the late 1990s, suggesting anticipation rather than echoing.

62 Gilles Cusson, s.J., Biblical Theology and the Spiritual Exercises (St. Louis: Institute of Jesuit Sources, 1988), cf. Cusson, The Spiritual Exercises Made in Everyday Life: A Method and a Biblical Interpretation (Anand: Gujarat Sahitya Prakash, 1992). 
[a nod to all, but especially to Protestants and Pentecostals]. This contemplation, then, is not a mere act of filial piety on the part of Ignatius, but is to be the model in which we see the perfection and wholeness of all the ways in which the Christ of Easter comes to his own $[\ldots]]^{63}$

By the early 2000s, the work of cis (as it was now called) had grown exponentially. Puleng Matsaneng developed a new form of Ignatian spirituality directed at discussion groups in township parishes, where the individually guided retreat model seemed not to work. This has been seen as a major innovation in the worldwide ministry of the Exercises. ${ }^{64}$ Though a thoroughly lay-led operation, a number of Jesuits were directly involved in it. It would become the core of a new regional project that would draw Vuselela/cis firmly into the life and work of Jesuits in South Africa, the Jesuit Institute.

Since the 1970s, the Society of Jesus in South Africa had no institutions of its own. The Society worked in parishes, chaplaincies, and schools (the latter being part of the Marist Brothers institutions). It also worked in both major seminaries, St. John Vianney (Pretoria) and St. Joseph's (Cedara, near Pietermaritzburg), with the understanding that they were there temporarily, particularly in Pretoria where the Society had an understanding with the SACBC that it would withdraw once adequate diocesan formators could be trained and deployed there. At the turn of the millennium, two Jesuits-Gerard Walmsley (b.1951) and Anthony Egan (b.1966) - taught at St. Augustine's College, a small Catholic university in Johannesburg. All these educational institutions were places of ecumenical encounter. But the pressure from Rome was for South Africa to develop its own distinctive Jesuit institution.

Given that Jesuits were few in South Africa (about twenty-five), there was no chance of developing a Jesuit retreat house, Jesuit social institute, or Jesuit university. In light of this, and no doubt noting the success of Vuselela, the then regional superior Mike Lewis (b.1949) - in consultation with the region -instituted the Jesuit Institute South Africa (JISA) in early 2007. Incorporating Vuselela and its team, and led initially by former British provincial David Smolira (b.1955), JISA combined a non-residential spirituality program (Vuselela) with academic teaching (Egan left St. Augustine's permanent staff, remaining a sessional lecturer there; Peter Knox [b.1962] joined the team from his work in seminaries) and a kind of social apostolate ministry.

From the onset, JISA's work took on both an intra-ecclesial and ecumenical nature. Its focus was on dialogue with the Catholic and other churches, with

63 Fitzsimons, “Theology," 112.

64 Annemarie Paulin-Campbell and Puleng Matsaneng, "Evolving Approaches to Spiritual Direction in South Africa," The Way (July 2013): 7-22. 
other faiths, and with a broader dialogue with South African society. This was uneven, from the start. While the Spirituality Team continued to make considerable inroads into other churches, under Smolira and his successor Raymond Perrier (b.1966) (a former British province Jesuit scholastic and advertising executive) JISA gained considerable influence within the South African Catholic Church. This influence continues under the current director, Russell Pollitt (b.1975). As the institute built up its engagement with wider society, often serving as a critical voice at a time when much church engagement with the state was fairly muted (or limited to such areas as abortion and gay marriage), JISA started to gain an international reputation. Because JISA responded quickly to crises in South African politics, faster than the SACBC in many cases, it attracted the attention of international Catholic media, including Vatican Radio, for comment. Simultaneously, Pollitt and his colleagues built up ties with the secular media - with the online Daily Maverick newspaper, with the independent E-TV news channel, and with a number of radio stations. JISA became the first place for comment on religious matters-like the beatification of Benedict Daswa (1946-90), the election of Pope Francis (r.2013-) - with these sources.

With still-greater direct Jesuit involvement, the Spirituality Team grew the Exercises in South Africa further, making inroads into the Protestant community. The ecumenical dimension of the work deepened: it was not (and is not) uncommon for an eight-day retreat to be led by a combination of Jesuit and lay JISA staff, combined with Protestant directors trained by JISA. Often, too, the retreat would occur in a Methodist or Anglican retreat center. There remain some retreats that are all-Catholic affairs, and some that are completely run by Protestants. JISA's regular directory of retreats reflects this diversification of the Exercises in South Africa.

Protestants have taken to the Exercises in South Africa dramatically, perhaps more so than South African Catholics, many of whom still operate out of a traditional devotional spirituality. The director of spiritual formation for one denomination is a fully trained Ignatian director connected to JISA's extended network of associates. She takes each graduating class of her seminarians through an eight-day retreat before they are ordained.

Spiritual direction and the Exercises have also transformed Jesuit encounters with Protestants. Through knowing the Society through the Exercises, as opposed to the internet-based network of grand conspiracy theories, Protestants have drawn on Jesuits to advise them on ad hoc bases on a number of occasions. And numerous Jesuits direct a swathe of Protestant clergy and laity_including numerous Anglicans and Methodists, a few Baptists, a number of Dutch Reformed clergy and laity, and even a few Pentecostals.

It goes both ways, however. A retired Anglican bishop (who comes from the church's evangelical wing) is a spiritual director to a Jesuit. 
The ministry of Ignatian spiritual direction, pioneered by the mainly laywomen - accompanied and supported by the Society in South Africa—of the CIS, now part of JISA, has transformed Jesuit relations with Protestants in South Africa. From the isolation of the Catholic laager of the nineteenth century, ${ }^{65}$ through mainly individual efforts at dialogue in the twentieth, Jesuits-particularly those at JISA - are engaged in practical ecumenism. Ironically, none of this was ever planned. No regional superior with his consultors ever developed a policy, ever wrote a plan for ecumenism.

\section{Conclusion: Developing a General Theory of Ecumenical Encounters in South Africa}

The central thesis I would propose is this: Spirituality is ecumenical. Justice is ecumenical. The truth of these maxims is borne out by the developments we have seen in the Society of Jesus in South Africa since the $187 \mathrm{os}$. Where dogma intrudes, there is often deadlock - though, in the case of Jesuits, since they have never had a strong tradition of theological scholarship in South Africa, this had not been an obstacle.

A subsidiary thesis I would add is: History—sacred and secular, if one still wants to distinguish them-has intruded on what Jesuits could do. Centuries of anti-Catholic public discourse in the country, from active proscription to cool indifference, has made ecumenical dialogue for the church and the Jesuits difficult. Similarly, Catholic hostility to Protestants - an obsession with the Reformation, particularly among British Jesuits who largely seeded the Society in modern South Africa-has also contributed. The ambivalent messages about ecumenism and its limits coming from the Second Vatican Council and its subsequent cautious interpretation coming from Rome and applied by the SACBC made ecumenism outside of non-sacramental and non-dogmatic matters difficult. The overall move of the church in South Africa has been from open hostility through polite indifference to polite conversation and limited cooperation on justice matters. ${ }^{66}$ In matters of spirituality, the SACBC has also remained muted; only Ignatian spirituality promoted by individual Jesuits and by JISA has had a real impact.

A second subsidiary thesis I propose is: Given the limitations of numbers in the region, the influence of the British province's general caution regarding

\footnotetext{
65 From the Dutch/Afrikaans: a circle of wagons drawn together for defense at night (or in battle) during the nineteenth-century South African "Great Trek" (c. 1835-40). 
ecumenism, and the nature of the works done by the Society in South Africa, meaningful ecumenical encounter with Protestants was both limited and work-driven. Those Jesuits who worked in parishes, seminaries, and chaplaincies were within a Catholic milieu. What engagement they may have hadin ministers' fraternals, in ecumenical chaplains meetings at universities, in working with academic colleagues from Protestant theology faculties-were incidental to their work focus, add-ons to already busy schedules. There was little time for depth, even if such depth had been actively encouraged by the Society or the SACBC.

My final thesis returns to the caveat I issued at the beginning. For much of this subject we simply cannot know the details. The data is not there. It is not to be found in the official documents of the Society in South Africa, nor in the records (such as they are) of individual Jesuits and Jesuit works. Though the snapshots exist, they cannot give us more than a blurry picture. To use another visual analogy, this aspect of Jesuit history in South Africa is like an old film, all copies of which have been lost. Only a grainy collection of still photos remain.

\section{Bibliography}

\section{Primary Sources}

Society of Jesus in South Africa: Regional Archives (Johannesburg).

Zambesi Mission Record, 1898-1934 [missionary magazine of the then "English province" of the Society of Jesus, focusing on the missions of southern Africa].

Letters \& Notices 1895- [internal magazine of the British province of the Society of Jesus].

University of the Witwatersrand (Johannesburg): Historical Papers Collections.

University Christian Movement Papers (AD1126).

\section{Published Sources (Books and Articles)}

Abraham, Garth. The Catholic Church and Apartheid: The Response of the Catholic Church in South Africa to the First Decade of National Party Rule, 1948-1957. Johannesburg: Ravan Press, 1989.

Balia, Daryl M. Christian Reaction to Apartheid: Ecumenism in South Africa 1960-1987. Braamfontein: Skotaville Publishers, 1989.

Brown, William E. The Catholic Church in South Africa: From Its Origins to the Present Day. Edited by Michael Derrick. London: Burns \& Oates, 1960.

Carr, E.H. What Is History? Harmondsworth: Penguin, 1961.

Chikane, Frank. No Life of My Own: An Autobiography. London: Catholic Institute for International Relations, 1988. 
Cusson, Gilles S.J. Biblical Theology and the Spiritual Exercises. St. Louis: Institute of Jesuit Sources, 1988.

Cusson, Gilles S.J. The Spiritual Exercises Made in Everyday Life: A Method and a Biblical Interpretation. Anand: Gujarat Sahitya Prakash, 1992.

Egan, Anthony. The Politics of a South African Catholic Student Movement. Cape Town: University of Cape Town Centre for African Studies, 1991.

Elton, Geoffrey R. The Practice of History. London: Fontana, 1969 [1967].

Frank L Coleman, St Aidan's College. Grahamstown: Rhodes Institute for Social and Economic Research, 1980.

Geyl, Pieter. The Revolt of the Netherlands 1555-16og. New York: Barnes \& Noble, 1966.

Gruchy, John W. de. The Church Struggle in South Africa. Cape Town: David Philip, 1979.

Hinwood, Bonaventure. "Ecumenism." In The Catholic Church in Contemporary Southern Africa, edited by Joy Brain and Philippe Denis, 349-85. Pietermaritzburg: Cluster Publications, 1999.

Houston, William John. "A Critical Evaluation of the University Christian Movement as an Ecumenical Mission to Students 1967-1972." MTh thesis, University of South Africa (UNISA), 1997.

Israel, Jonathan I. The Dutch Republic: Its Rise, Greatness, and Fall 1477-1806. Oxford: Clarendon Press, 1998.

Jenkins, Keith. On What Is History? From Carr and Elton to Rorty and White. London: Routledge, 1995 .

Kentridge, Matthew. An Unofficial War: Inside the Conflict in Pietermaritzburg. Cape Town: David Philip, 1990.

Keteyi, Xolile. Inculturation as a Strategy for Liberation. Pietermaritzburg: Cluster Publications, 1998.

Lewis-Williams, David, and David Pearce. San Spirituality: Roots, Expression and Social Consequences. Walnut Creek, CA, and Cape Town: AltaMira Press and Double Storey, 2004.

Lorriman, Gerard. "Report from the Western Cape." Letters \& Notices (Summer 1994): $16-26$.

MacQueen, Ian. "Students, Apartheid and the Ecumenical Movement in South Africa 1960-1975." Journal of Southern African Studies 39, no. 2 (2013): 447-63.

Marwick, Arthur. The Nature of History. 3rd ed. London: Macmillan, 1989.

McKay, Clare Elizabeth Ann. "A History of the National Union of South African Students, 1956-1970." D.Litt. et Phil dissertation, UNISA 2015.

Parker, Geoffrey. The Dutch Revolt. Harmondsworth: Penguin, 1977.

Paulin-Campbell, Annemarie, and Puleng Matsaneng. "Evolving Approaches to Spiritual Direction in South Africa." The Way (July 2013): 7-22.

Paulin-Campbell, Annemarie. "A Lay Foundation, a Shared Enterprise." Review of Ignatian Spirituality 104 (2003): 38. 
Ryan, Judy Ann. "An Examination of the Achievement of the Jesuit Order in South Africa, 1879-1934." MA thesis, Rhodes University, 1990.

Smith, Tim. They Are Killing Our Children. Pietermaritzburg: Pietermaritzburg Agency for Christian Social Awareness, 1990.

Tachard, Guy. A Relation of the Voyage to Siam: Performed by Six Jesuits Sent by the French King, to the Indies and China in the Year 1685. Bangkok: White Orchid Press, 1981 [1688].

Tosh, John. The Pursuit of History. 2nd ed. London: Longmans, 1991.

Walshe, Peter. Church versus State in South Africa: The Case of the Christian Institute. London: Hurst, 1983.

Walshe, Peter. "Mission in a Repressive Society: The Christian Institute of Southern Africa." International Bulletin of Missionary Research 5, no. 4 (October 1981): 146-52.

Walshe, Peter. Prophetic Christianity and the Liberation Movement in South Africa. Pietermaritzburg: Cluster Publications, 1995. 


\section{Encounters between Jesuit and Protestant Missionaries in their Approaches to Evangelization in Zambia}

Choobe Maambo, s.J.

Africa's reception of Christianity and the pace at which the faith permeated the continent were incredibly slow. Although the north, especially Ethiopia and Egypt, is believed to have come under Christian influence as early as the first century, it was not until the fourth century that Christianity became more widespread in north Africa under the influence of the patristic fathers. From the time of the African church fathers up until the fifteenth century, there was no trace of the Christian church south of the Sahara. According to William Lane, s.J.:

It was not until the end of the fifteenth and sixteenth centuries that Christianity began to spread to the more southerly areas of Africa. The Portuguese, in their search for a sea route to India, set up bases along the East and West African coasts. Since Portugal was a Christian country, missionaries followed in the wake of the traders with the aim of spreading the Gospel and setting up the Church along the African coasts. ${ }^{1}$

Prince Henry the Navigator (1394-1460) of Portugal was the man behind these expeditions, in which priests "served as chaplains to the new trading settlements and as missionaries to neighboring African people." 2 Hence, at the close of the sixteenth century, Christian missionary work had increased significantly south of the Sahara. In Central Africa, and more specifically in the Kingdom of Kongo, the Gospel was preached to the king and his royal family as early as 1484. In 1518, the king's son, Henry (c.1495-c.1526), who trained as a priest in Portugal, was made the first African bishop. ${ }^{3}$ This was followed by the entry

1 William Lane, Jesuits in Zambia: 1880-1991 (Lusaka: Ndola Mission Press, 1991), 1.

2 T.A. [Thomas Allan] Beetham, Christianity and the New Africa (London: Pall Mall Press, 1967), 8.

3 C.P. [Charles Pelham] Groves, The Planting of Christianity in Africa (London: Lutterworth Press, 1958), 128-29. 
of missionaries into Angola in 1560, when Jesuits accompanied Portuguese explorers into the country. Although they did not accomplish much at the time, when they returned in 1574 they were able to convert the king and baptize some of his subjects. ${ }^{4}$

On the southern end of the Sahara, the Portuguese missionaries infiltrated the land from Mozambique and South Africa through the mouth of the Zambezi River into what is now Zimbabwe. In 1561, king, or Mwene Mutapa, of the Shona people and his royal family were baptized by a Jesuit priest, Gonçalo da Silveira $(1526-61){ }^{5}$

Sadly, these Catholic missionary activities at the close of the fifteenth and the dawn of the sixteenth centuries started to diminish by the end of the eighteenth century; when new missionary movements emerged at the beginning of the nineteenth century, there were only a few traces and fading memories of Catholicism in the region. One major reason for this was the diminishing presence of the Portuguese and the subsequent dwindling of their foreign trade policies in this part of the world.

However, at the end of the eighteenth century, a new wave of missionary movements began to emerge, this time initiated by Protestant missionaries. This was partly due to the evangelical revival that had taken place in Europe and North America. According to historian Mark R. Shaw:

At the heart of these evangelical revivals were three powerful convictions. The first was the centrality of the death of Christ for salvation. The second was the necessity of the new birth. The third was a new eschatology that envisioned the spread of Christianity around the world as a prelude to Christ's personal return. ${ }^{6}$

Thus, the end of the eighteenth century and the dawn of the nineteenth saw an increased number of missionary societies south of the Sahara. However, unlike in the pre-eighteenth-century period, this time the evangelization field was split between Protestant and Catholic missionaries.

This chapter explores the missionary movements in Africa at the end of the eighteenth and the beginning of the nineteenth century. During this period, a range of Protestant missionary societies were established that were later sent

4 Ibid., 130.

5 John Baur, 2000 Years of Christianity in Africa, 2nd ed. (Nairobi: Paulines Publications Africa, 2009), 80-81.

6 Mark R. Shaw, The Kingdom of God in Africa: A Short History of African Christianity (Grand Rapids: Baker, 1996), 129 . 
to Africa and other parts of the world. By the close of the eighteenth century, both Protestant and Catholic missionaries were working alongside one another to proclaim the kingdom in Africa and elsewhere. The chapter focuses more explicitly on the relationship between the Protestant and Jesuit missionaries who worked in the region that became today's Zambia. This is followed by an analysis of their methods and approaches to evangelization. The chapter concludes with a comparative statistical analysis of the respective achievements and failures of the Jesuits and Protestants in the Zambian mission field.

\section{Historical Background to the Entry of Protestant Missionaries in Zambia}

During the eighteenth-century Protestant evangelical revival in Europe and North America, Protestant churches established missionary societies that would later be sent to Africa to proclaim the Gospel. When Protestant missionaries traveled to the southern part of Africa in the nineteenth century, they found few traces of Catholicism in the region. According to Thomas Allan Beetham, a Methodist minister:

When [...] a new missionary movement to Africa began at the end of the eighteenth century - this time initiated by Protestant Churches and as a result of the evangelical revival in Europe- traces of the previous Catholic movement were almost non-existent. There were a few ruined walls, a crucifix among the sacred objects of a local shrine, and faint memories in tradition of a god who died. ${ }^{7}$

David Livingstone (1813-73) gives similar evidence of the fading traces of Christianity in Angola. He describes two churches and a hospital that lay in ruins as well as the remains of two convents. He further pays tribute to the Jesuits, Benedictines, and Capuchins for their service and missionary work. Speaking of the capital itself, he wrote that "there are various evidences of its former magnificence, especially two cathedrals, one of which, once a Jesuit college, is now converted into a workshop, and in passing the other we saw with sorrow a number of oxen feeding within its stately walls."

7 Beetham, Christianity and New Africa, 8-9.

8 DavidLivingstone,MissionaryTravelsandResearchesinSouthAfrica(London:Ward,Lock\& Co., 1857), 340-41. 
The Protestant missions began in 1792, with the Moravian Church being the first to send its missionaries to Africa. However, despite establishing themselves in the region in 1792, it was only around the 1880 os that these Protestant missionary societies were able to establish missions in Northern Rhodesia, present-day Zambia. Livingstone, representing the London Missionary Society (LMS), was the first Protestant missionary to reach Zambia, making three trips to the country in 1851,1853 , and 1873 . Livingstone's first two trips were to the western province of Zambia. During his third trip, he went as far as Ujiji and Tabora, in present-day Tanzania, before traveling back to central Zambia in Serenje where he died in $1873 .{ }^{9}$ Livingstone's visits to Zambia laid the foundation for the missionary activities that were to take place in later years. In his famous speech at the Senate House of Cambridge University on December 4, 1857 , he made an appeal for volunteers, inviting them to follow in his footsteps. ${ }^{10}$ In response, many Protestant mission stations opened in Africa and, in particular, Zambia.

The first Protestant missionary to set up a mission within the borders of the future Northern Rhodesia was Frederick Stanley Arnot (1858-1914), a Plymouth Brethren missionary, who settled in Barotseland, Lealui, in 1882. When he arrived in South Africa at the age of twenty-four, he had aimed to open a mission along the upper Zambezi River. Once this had been achieved, he hoped to summon reinforcements and to continue the course proclaimed so boldly by Livingstone. As he moved northward into the interior, he began to evangelize among the Toka-Leya and the Tonga people who lived around the Victoria Falls. But before he could do so, he sought to obtain permission from Lewanika (1842-1916, r.1876-1916), the king of the Lozi people. On November 20, 1882, Arnot arrived at Lealui, the capital of Lewanika's kingdom. ${ }^{11}$ Thus, even before Cecil John Rhodes (1853-1902) began to think about the territory beyond the Zambezi River, Arnot had already established himself among the Lozi people of today's Western Province of Zambia.

The LMS was the second missionary group to establish itself among the people of Zambia. Despite being the first missionary society to have influence on the Zambian people through Livingstone, the LMs did not establish a permanent mission until 1883 , ten years after Livingstone's death. Unlike

The Participatory Assessment Group, The Church's Contribution to Development in Zambia (Lusaka: The Group, 2000), 3 .

10 William Monk, ed., Dr. Livingstone's Cambridge Lectures (Cambridge: Deighton Bell, 1860), 24.

11 Peter D. Snelson, Educational Development in Northern Rhodesia 1883-1945 (Ndola: National Educational Company of Zambia, 1974), 27-28. 
most missionary societies, which were denominational, the LMS was generally known for its interdenominational spirit. The first LMS mission stations in Northern Rhodesia were founded at the mouth of the Lofu River, Niamikolo, and Fwambo in 1883, 1885, and 1887 respectively. The mission at Niamikolo was the first mission settlement in the northern part of Zambia.

The third missionary society to establish itself in Northern Rhodesia was the Paris Missionary Society (PMS). Led by François Coillard (1834-1904), the PMS established a mission in the western part of Northern Rhodesia, among the Lozi people. Coillard arrived at the upper Zambezi region in July 1884, accompanied by his wife, his niece, and some Sotho evangelists. Other members of his group included missionaries and people from other denominations and countries. Coillard established his first mission stations at Sesheke, Sefula, Kazungula, and Nalolo in 1885, 1886, 1889, and 1894. In 1887, Coillard opened one of the first schools in the region, which provided training in skills such as plowing and carpentry.

Following the PMS were the Primitive Methodists Missionary Society (PMMS), one of several movements that had broken away from the Wesleyan Methodist Church in the early part of the nineteenth century. The PMMS expedition to Northern Rhodesia consisted of Henry Buckenham (1844-96), his wife, and child; Arthur Baldwin, a young probation minister; and Mr. Frederick Ward, a layman. They left England in April 1889. In March 1890, they left for Kazungula on the Zambezi. The expedition finally arrived at the Zambezi, crossed the river, and settled at Sefula over six months after leaving South Africa. ${ }^{12}$ In 1893 , and having been granted permission by Lewanika, the team settled among the Illa people of the Kafue plains and opened their first mission at Nkala.

While other missionary societies were entering Northern Rhodesia through its southern and western borders, the Presbyterian Missionary Society entered through present-day Malawi, establishing their first mission at Mwenzo, near the Tanzanian border, in 1894. In 1905 and 1907, they established mission stations at Lubwe and Chitambo respectively. In 1965, a year after Zambia became an independent state, the four Protestant Church organizations, namely LMs, PMS, PMMS, and the Presbyterian Church, formed a single church known as the United Church of Zambia (UCz).

In 1905, William Harrison Anderson (1870-1950), a Seventh-day Adventist (SDA), opened a mission station at Rusangu, in Monze, among the Tonga people of the Southern Province. The Anglican missionaries also followed suit, opening mission stations in 1911 and 1912 at Msoro and Mapanza respectively.

12 John P. Ragsdale, Protestant Missions Education in Zambia, 1880-1954 (London: Associated University Presses, 1986), 22-23. 
According to social scientist Drew R. Smith, these mission societies met with different levels of failure in their attempts to establish mission stations, ${ }^{13}$ and it took them some time to succeed in their evangelizing endeavor. Historian Robert I. Rotberg writes of the difficulties that the Protestant missionaries encountered: "Of the approximately 1,500,000 Africans in Northern Rhodesia in 1924, no more than 18,000 had been baptized [...]. No indigenous ministers had been ordained, and none of the missions had tried seriously to encourage the participation of African congregations in the government of the local churches."14 One major reason for this was that the early missionaries were closely associated with the colonial government officials. The PMS, which worked among the Lozi people, for instance, gave the British Southern Africa Company (BSAC) permission to operate in its territories. According to Rotberg:

Missionaries helped the government to collect taxes, several made church membership conditional upon the payment of taxes and nearly all failed to see the contradictory expectation that such action would arouse among Africans [...]. Missionaries were generally content with the Company's method of governance. They frequently said so and defended the Company from overseas criticism. ${ }^{15}$

Because of this, it took time for the Protestant missionaries' work to yield fruit on Zambian soil. However, as time went by, they were able to insert themselves into the local societies and to plant a seed of Christianity in the country. The Protestant churches also contributed toward improving the lives of the local people whom they evangelized, especially through education, health services, and training in agriculture and other skills.

\section{Historical Background to the Entry of Jesuit Missionaries in Zambia}

The first Jesuit missionaries to set foot on the continent of Africa were St. Francis Xavier (1506-52) and his two companions. In 1541, a few months after the founding of the Society of Jesus, Xavier and two other Jesuits spent

13 Drew R. Smith, "Missionaries, Church Movements, and the Shifting Religious Significance of the State in Zambia," Journal of Church and State 41, no. 3 (1999): 525-50, here 528.

14 Robert I. Rotberg, Christian Missionaries and the Creation of Northern Rhodesia: 1880-1924 (Princeton: Princeton University Press, 1965), 139-40.

15 Ibid., 100-1. 
six months in Mozambique while waiting for the wind to take them to Goa. ${ }^{16}$ Despite the long stay, Xavier and his companions did not make contact with the African people and only preached the Gospel to the Portuguese Christians they had traveled with. It was only in the 1560 s that the Jesuits began to plant Christianity in the southern part of Africa, and it would take nineteen further years for another Jesuit to set foot on the southern shores of Africa after Xavier had left for Goa. In 156o, Silveira, a Jesuit priest from a noble Portuguese family, made contact with Mwene Mutapa, the king of the Mashona people of Zimbabwe. In 1561, the then Mwene Mutapa, his mother, and other members of the royal family agreed to be baptized by Silveira. Yet, barely a month after the king's baptism, Silveira was strangled to death, allegedly at the instigation of a local medicine man (ng'anga) and some Muslim traders who had accused Silveira of being a witch and a Portuguese spy. ${ }^{17}$

After Silveira's death, it took some time for Jesuit missionaries to return to this part of the continent; indeed, it was only in 1610 that the next venture into Mozambique took place. On the western side of southern Africa, Jesuits accompanied the Portuguese explorers into Angola in the 1560 s but were unable to accomplish anything until 1574, when they began opening schools, colleges, hospitals, and ministries related to evangelization in both Mozambique and Angola. These missionary activities thrived until the eve of the general suppression of the Society of Jesus in 1773 .

These pre-suppression missionary activities of the sixteenth, seventeenth, and eighteenth centuries did not penetrate into present-day Zambia, and it was only after the lifting of the suppression by Pope Pius VII (1742-1823, r.180o23) in 1814 that Jesuits returned to Africa. During this period, they were able to penetrate the interior of the upper Zambezi, becoming part of a new wave of Catholic evangelization in Africa that began in the nineteenth century. According to Fr. Brendan Carmody:

The Catholic revival of the nineteenth century had begun as a response to the Protestant investment in missions. In 1816, the Roman Propaganda Fide was re-established by Pope Pius VII as the chief authority of missions. Another major contributing factor to the expansion of the Catholic missionary endeavor was the establishment of the Society for the Propagation of Faith by Pauline Jaricot in $1822 .{ }^{18}$

\footnotetext{
16 Bengt Sundkler and Christopher Steed, A History of the Church in Africa (Cambridge: Cambridge University Press, 2000), 70.

17 Elizabeth Isichei, A History of Christianity in Africa from Antiquity to the Present (Lawrenceville, NJ: Africa World Press, 1995), 68.

18 Brendan Carmody, Education in Zambia:Catholic Perspectives (Lusaka:Bookworld, 1999), 4.
} 
The first attempt by the Jesuits to enter present-day Zambia began with the creation of the Zambezi Mission by a decree of the Propaganda Fide. In 1879, the Zambezi Mission, which roughly comprised present-day Zambia and Zimbabwe, was officially opened. Superior General Peter Jan Beckx (1795-1887, in office 1853-87) appointed Henry Depelchin (1822-1900), a Belgian Jesuit, to lead a band of eleven Jesuits across the Limpopo River. By March 1879, these men were ready for the interior journey, and by June 1880 , they had arrived at Pandamatenga, around ninety kilometers southwest of the Victoria Falls. However, they were unable to cross the Zambezi River into the Barotseland of Zambia because of a civil war in that part of the country, and they were also waiting for permission from Lewanika, the Lozi king, to enter the territory. Thus, after establishing a base at Pandamatenga, they decided to cross the Zambezi River farther east. On August 9, 1880, they arrived in the chiefdom of Mweemba of the Tonga people of the Southern Province of Zambia. Mweemba gave them a warm welcome and granted them a piece of land at Siameja village, giving them permission to settle there as long as they wished. Finally, in 1883 , after three years of further waiting, Lewanika granted them permission to enter his kingdom, but he did not give them a permanent place to settle. As a result, the first attempt to establish a Jesuit mission north of the Limpopo ended in failure. According to Thomas McGivern, S.J. (1927-2017) and Sister Mary O'Brien, "Fr. Depelchin was recalled to Europe in 1883 [...]; his mission had failed completely: seven of his men were dead - two by drowning, one by falling from a horse's back, four by fever, and the rest were more or less broken in health and greatly disappointed." 19

It should be noted here that the Jesuits were not the first Catholic missionaries to enter Zambia or to establish a mission. According to historian Hugo F. Hinfelaar:

The people of Zambia had been in contact with Catholic Christendom from the beginning of the eighteenth century onwards. The first contact was with the Portuguese-speaking Dominican missionaries who arrived around 1730 in a market place known as Feira to the Portuguese, situated at the confluence of the Luangwa River and Zambezi River, near the district center of present day Luangwa-Mburuma, the local ruler, had given them a piece of land near the market, Feira, on the northern bank of the river. There one of them had built a chapel and dedicated it to Our Lady of the Rosary. His name was Father Pedro da Santíssima Trinidade (Fr. Peter of Holy Trinity). He was not a Portuguese European, but a

19 Thomas McGivern and Mary O'Brien, Diocese of Monze: A Digest History 1905-2005, ed. Joseph Braun (Monze: Diocese of Monze, 2005), 20. 
Goanese Indian who became a Friar in the order of St. Dominic. He may well have been the first Catholic priest who celebrated the Eucharist in Zambia, though a place of worship appears to have been constructed in Zumbo itself in 1729 by Father Manoel da Conceicao [ sic]. ${ }^{20}$

In the northern part of Zambia, the Missionaries of Africa, popularly known as the White Fathers because of their white robes, entered the region in 1891 and settled near Mambwe-Mwela in the far north, from where they founded a string of mission posts among the Bemba-speaking tribes. ${ }^{21}$ "Their first mission station was established in 1895 in Chief Makasa's area. The mission was opened at Kayambi, 40 kilometers south of Mambwe. Father Joseph Dupont (later nick-named Moto Moto) gained permission to set up a mission."22

Hence the Dominicans had already visited the Luangwa Valley in the 1730s, and the White Fathers had established their mission stations among the Bemba-speaking tribes in the 1890 s.

After the Jesuits' first attempt to set up a mission station north of the Zambezi had failed in 1883, a second, successful attempt was initiated by Peter Prestage, S.J. (1842-1907) and Joseph Moreau, S.J. (1864-1949). In 1902, Prestage and Moreau crossed the Zambezi River and arrived in the chiefdom of Monze. According to Lane, Prestage and Moreau established a cordial relationship with Chief Monze who asked them to open a mission station in the area. But, before they could do so, the two missionaries wanted to perfect their skills in the local language; they consequently identified a potential site for a mission station and, in the meantime, went back to Empandeni outside Bulawayo in Zimbabwe to learn the language. Chief Monze allowed four young men to travel with them.

When these young men arrived in Empandeni with Prestage and Moreau, they were introduced to new skills such as improved plowing methods; they also learned English while Prestage and Moreau learned Tonga. After catechetical instructions, these young men were baptized. In 1905, Prestage, Moreau, and the four young men, this time accompanied by a linguist, Julius Torrend, S.J. (1861-1936), returned to Chief Monze and settled at Chikuni on July 14, 1905. Thus, the Catholic Church was born in the southern part of Zambia. In October 1905, Torrend moved farther north where he established a mission at

20 Hugo F. Hinfelaar, History of the Catholic Church in Zambia (Lusaka: Bookworld, 2004), $1-2$.

21 Ibid., 1.

22 Participatory Assessment Group, Church's Contribution, 5. 
Kasisi. ${ }^{23}$ From 1905 , the Society of Jesus spread rapidly throughout the southern and central parts of Zambia.

\section{Competition between Jesuits and Protestants over Territory and Population}

To a large extent, the encounter and relationship between the early Jesuit and Protestant missionaries was grounded on the policies of the colonial government of the time. Around 1897, the BSAC, led by Cecil Rhodes, had occupied much of the territory north of the Zambezi, which we now call Zambia. In its guidelines for administration, and having experienced how tense the relationship between Christian denominations in Europe and Britain in particular could be, the colonial government's policy was to keep the Catholic and Protestant missionaries apart from each other; no one was to set up a mission station within a ten-mile radius of an already existing mission. ${ }^{24}$

Hence the role of the government was to control and monitor the Jesuit and Protestant missionaries. As such, in their quest to expand and control the region, the colonial government asked some missionary groups to open mission stations in areas they felt they could occupy. For instance, Rhodes, in the context of the area's expansion and development, asked the Jesuits to open a mission north of the Zambezi. Taking into account the boundaries of the Zambezi Mission, laid down twenty years before, and also knowing the mind of Rhodes, while being conscious of their mission to spread the Gospel, the Jesuits agreed to open mission stations within the boundaries of the Zambezi Mission. ${ }^{25}$ Around the same time, other missionary groups were also emerging with the aim of evangelizing Africans. As these different missionary societies went about realizing this aim, they encountered each other in the field of evangelization, and in some contexts these encounters were characterized by competition over territory and population. In the western part of Zambia, for instance, when Jesuits first arrived in the territory, they were refused entry into the Barotseland by King Lewanika until three years later. And when they were eventually given permission to enter, the king refused to give them a permanent place to settle. It would appear that the Protestant missionaries who had settled there had poisoned the mind of the king, urging him not to

23 Lane, Jesuits in Zambia, 9.

24 Edward P. Murphy, interview with Choobe Maambo, Jesuit novitiate, June 27, 2016.

25 Lane, Jesuits in Zambia, 8. 
give land to the Jesuits for fear of competition. ${ }^{26}$ According to historian Edward Murphy, "the result was that if permission was granted to one body to settle in a territory, these would advise the chief to keep out all other Christian organizations."27

The Protestant and Catholic missionaries sometimes accused one another of trespassing into each other's territories. Historian Edward H. Berman claims that "Catholics were unwilling to abandon even part of the African field to the Protestant societies. To do so would be tantamount to denying the worldwide mission of the Catholic Church and admitting the legitimacy of the sixteenthcentury schism between Rome and Wittenberg." ${ }^{28}$ Generally, the colonial government's policy of monitoring and controlling the missionaries in their territories seems to have been ineffective. As Berman asserts, "the inability of [the] colonial government to limit missionary expansion in their territories led to great overlapping, and not infrequently to conflict, between rival denominations attempting to gain an advantage over a competing society." 29

\section{The Rivalry between Jesuit and Protestant Missionaries}

Berman describes the relationship between Jesuits and Protestants as being "very bitter," ${ }^{30}$ with the rivalry that characterized the sixteenth-century Reformation in Europe manifesting itself in the relationship between the missionaries as they engaged in evangelization activities within Zambia. The general attitude of the Jesuits was that Protestants were heretics who were destined for eternal damnation. Similarly, Protestants saw Jesuits to be in serious error and in danger of eternal damnation.

One example that illustrates this rivalry concerns the Protestant missionary societies' attempts to harmonize missionary activities. Between 1914 and 1945, Protestant missionary societies formed a body known as the General Missionary Conference (GMC), which called for a series of meetings to foster cooperation and coordination and to find ways of harmonizing their

26 Ibid., 7 .

27 Edward P. Murphy, "First Zambesi Mission," in A History of the Jesuits in Zambia: A Mission Becomes a Province, ed. Edward P. Murphy (Nairobi: Paulines Publications Africa, 2003), 6o-86, here 61 .

28 Edward H. Berman, ed., African Reactions to Missionary Education (New York: Teachers College Press, 1975), 21.

29 Ibid., 20-21.

$30 \quad$ Ibid., 21. 
missionary activities in the region. The main aim of the GMC as elaborated by historian Peter Bolink was "to promote cooperation and brotherly feeling between different missionary societies: to labor for the most speedy and effective evangelization of the races inhabiting North-western Rhodesia; to enlighten public opinion on Christian missions; [and] to watch over the interests of the Native races." ${ }^{31}$

The Jesuits did not take part in the conference until its third meeting in 1922, which was held at Kafue. One of the policies advanced at this meeting was the comity agreement, which limited the overlapping of missionary societies into other missionaries' spheres of influence. Rev. Douglas S. Gray (1883-1963), who spoke on this topic, "pleaded that the general principle of respecting the areas already occupied be respected."32 In order to enhance respect, coexistence, and cooperation between the different missionary societies, the GMC proposed that each society should stick to its boundaries and spheres of influence. The agreement stipulated that:

1. This conference while recognizing that spheres of influence may only be temporary, yet holds strongly that at this early stage in the development of mission work, there is ample room for missions to occupy distinct areas, and it would therefore remind all the missionary societies of the waste and friction that result from overlapping and urge them to avoid this evil wherever possible.

2. This conference trusts that any mission wishing to open works in a new area will first communicate with the executive of the conference.

3. In the event of a new society wishing to open work in the territory, or a society already at work in the territory wishing to open a new sphere, the conference would esteem it a favor if the administration would refer such society to its executive for information as to vacant areas before granting permission. ${ }^{33}$

The colonial government supported this policy and worked hard to implement it. "As early as 1899, the administrator recognized the need to take some action to control the operations of the missionary societies. Spheres of influence

31 Peter Bolink, Towards Church Union in Zambia: A Study of Missionary Co-operation and Church Union Efforts in Central Africa (Franeker: T. Wever, 1967), 132.

32 Proceedings of the General Missionary Conference of Northern Rhodesia, 1922 (Livingstonia: Mission Press, 1923), 13.

33 Ibid. 
had been demarcated for each society working in Northern Rhodesia." ${ }^{34}$ Yet the policy ultimately failed, with the Jesuits being among the first missionary groups to disregard the agreement. According to Bolink:

It was to be expected that Roman Catholic Missions would no longer accept such a restricting agreement [...]; other prominent cases, in which missions refused to comply with the government's sphere of influence policy were to occur in the Southern and Central provinces where, in particular, Jesuit missionaries objected to that policy. ${ }^{35}$

Thus, because of this restrictive policy, in 1935 the Jesuits stopped participating in the GMC upon instruction from Rome. Part of the reason for the Jesuit withdrawal was that they intended to expand their missions, and they did not want to be restricted by the policy of the sphere of influence that the conference was trying to uphold. ${ }^{36}$ In the period after their withdrawal,

the Roman Catholic missions greatly extended their influence mostly in Protestant areas, by building stations, usually within a distance of five to fifteen miles from existing Protestant missions. This caused much bitter feeling and strife, creating a deplorable picture of Christian disunity before the eyes of the people who had to be won for Christ. ${ }^{37}$

Hence the relationship between Jesuits and Protestants was sometimes characterized by rivalry and bitterness. According to Carmody, "the rather exclusive mission of the Catholic Church of that time meant that even Protestants were regarded as being in the shadow of death. Because of this general Catholic attitude to Protestants at this time, Catholics did not wish to be an integral part of these conferences." ${ }^{38}$ Rotberg summarizes this rivalry as follows:

The missionaries to Northern Rhodesia came from diverse backgrounds and brought to Africans the experience of a variety of occupations. They were fiercely independent men and they fought bitterly with one another [...] usually to the detriment of their evangelical objectives. In their individual journals and correspondence, expressions of fractiousness,

\footnotetext{
34 Ragsdale, Protestant Missions Education, 44.

35 Bolink, Towards Church Union, 128, 129.

$36 \quad$ Ibid., 131.

37 Ibid.

38 Carmody, Education in Zambia, 7.
} 
spitefulness, and jealousy compete with one another for space in numerous letters supposedly written more in sorrow than in anger. Indeed, missionaries seemed to spend as much time and energy committing these quarrels to paper as they did in seeking to accomplish conversion. ${ }^{39}$

A good example of these tensions is the encounter between Moreau and Anderson. When Moreau arrived in the Monze area in 1902, he identified a place where he could set up a mission. As already mentioned, after identifying a site he returned to Empandeni, Zimbabwe, to study the Tonga language. In 1905 , he returned to the site to begin his missionary work. However, upon arriving, he found that Anderson, the SDA missionary, had settled there two days earlier. This did not go down well with Moreau; he and his camp moved farther south in search for a new place, and the relations between the two men would remain strained for some time. ${ }^{40}$

In the western part of Zambia, the Jesuits encountered similar conflicts with the Dutch Reformed Church and the Methodists. "On the western side, the Dutch Reformed Church was also forced to compete with the expansive design of the Jesuits," says Rotberg. ${ }^{41}$ Talking about the encounter with the Methodists and the Adventists, one of the leading Jesuits claimed that

the day may not be far when the country will be overrun by Methodists and other sects [...]. There is still hope for us to make the Tonga nation a Catholic nation. [Moreover], I am now building our seventh outstation. It is a victory over the Adventists who had tried hard to get it. ${ }^{42}$

The Methodists responded to the Jesuit threat by opening a number of schools in Jesuit spheres of influence. In his diary, Oliver Roebuck, a Methodist missionary, states:

We hear that the Jesuits are keen to start work in two places where we have existing work [...]. Their Father Superior in these climes is a Pole, or some such nationality [...]. Here we are in this district, doing the best we can. The Jesuits want to come in the same place, whilst to the North there is a huge area untouched $\left[\ldots . .{ }^{43}\right.$

39 Rotberg, Christian Missionaries, 156.

40 Snelson, Educational Development in Northern Rhodesia, 95.

41 Rotberg, Christian Missionaries, 87.

42 Ibid.

43 Ibid., 88. 


\title{
Jesuit and Protestant Methods and Approaches to Evangelization
}

Despite the tension and competition between Jesuits and Protestants, the missionary societies used similar methods as part of their evangelization work. In the initial stages of evangelization, both set up centers of Christian influence. In Protestant terms, these centers were called mission stations. According to Beetham:

\begin{abstract}
Whereas in West Africa the center of Christian influence was the "mission house," in southern Africa, it was more often the mission station. Several missionary families lived there together. There were huts for the mission employees who looked after the wagon-teams and worked on the farm. Maize and vegetables were grown for the whole community including the small primary boarding school or training institution. ${ }^{44}$
\end{abstract}

These missions served as centers of learning and catechetical instructions, and by 1924 numerous stations had opened throughout Zambia. From these missions, Protestants were able to reach out to the local population.

In Catholic terms, the centers of Christian influence were called Christian villages. From the early days of their establishment, Jesuits attempted to set up such villages. In the Chikuni mission, for instance, Moreau acquired tracts of land, established villages, and invited families to set up homes. ${ }^{45}$ By 1924, the Chikuni mission alone had about four Christian villages that the priest frequently visited. Those who lived within these villages were expected to lead monogamous lives, attend Mass, and follow catechetical instructions. ${ }^{46}$

44 Beetham, Christianity and the New Africa, 13.

45 Lane, Jesuits in Zambia, 11.

46 However, the Christian village approach was questioned by some since it required having a good number of priests to cover the ground. One unidentified speaker at the 1920 Jesuit conference held at St. George's in Bulawayo, Zimbabwe, had this to say about the Christian village: "To have Christian kraal is, of course, the ideal thing: but the time for this has not come yet; for the existence of Christian kraal means too much centralization, whereas our great need is to widen our spheres of influence, and we have, as it is, far too few missionaries for this." See "Minutes of Missionary Conference Held at St. George's in Bulawayo," June 22-27, 1920, as quoted in Carmody, Education in Zambia, 8-9. Despite this view, Christian villages continued to be the basic spheres of influence. Thus, "conversion was often achieved through a village or school system that included repetition, memorization, of catechetical formulae, and at least outward conformity to certain demands like monogamy, Sunday Mass, and frequent confession." Brendan Carmody, "Conversion 
One element given greater emphasis in the Catholic evangelization was the importance of making material improvements to people's lives as a way to attract them to the faith. At that time, there were persistent famines and people needed food, clothing, and money to pay the taxes that had been introduced by the colonial government. In the desire to improve people's lives, Moreau set himself the task of improving their farming methods by introducing the plow. In the process, he attracted a large number of people to the faith.

Jesuit Christian villages and Protestant mission stations were later superseded by the school system, ${ }^{47}$ which became a means to influence the local population. This is one of the reasons why Jesuits established schools wherever they opened a mission. "When a school had been set up, one could begin to claim a rather exclusive right to the population of the area under what became known as the spheres of influence," says Carmody. ${ }^{48}$ For the Jesuits, any program of study was school oriented. What was probably typical of the Jesuits was that, in their missions, they established schools that became training centers for catechists. However, schools were not exclusive to the Jesuits. In fact, one could claim that wherever the early missionaries set up a mission or a church, there too one found a school. Among the early mission stations that were established by LMS, PMS, Presbyterian, Anglicans, and the SDA, there were schools. According to the Participatory Assessment Group's research, among the first missions in Zambia that were founded at Niamikolo, Fwambo, Kambole, Kawimbe, and Chikuni, schools were set up as well. In 1912, the Methodist Missionaries founded the Chipempi mission where they started a school for girls. Both the Anglicans and SDAs opened mission stations and centers of early learning in the Southern Province of Zambia. The Dutch Reformed Church opened a station at Magwero where they started a school for the blind, deaf, and dumb, as well as physically and mentally challenged children. All these stations and schools, both Jesuit and Protestant, were meant to be vehicles of evangelization.

\section{Differences in Jesuit and Protestant Theological Approaches in Zambia}

One major difference between the Jesuits and the Protestants in their approach to evangelization was in the area of theology. The missionaries came to Africa from different theological backgrounds. The Protestant theology at

to Catholicism in Zambia: 1891-1924," Missiology: An International Review 27, no. 2 (1999): 195-209, here 195 .

Ibid.

48 Ibid., 9 . 
the time was more influenced by Reformation theology, while Jesuit theology reflected pre-Vatican II (1962-65) principles. The Protestants rejected most of the Catholic Church's doctrinal teaching. At the heart of Protestant theology was sola scriptura (the supremacy of scripture in matters of faith, life, and conduct); sola fide (justification by grace alone through faith); and the priesthood of all believers, meaning that all believers are priests before God through Jesus the high priest. As a result, Protestant theology rejected papal supremacy, the merit of good works for salvation, veneration of Mary and the saints, and all but two sacraments instituted by Jesus: baptism and Holy Communion. The doctrines of transubstantiation, purgatory, and the requirement to confess to a priest were rejected.

Jesuits and Catholics in general held to the principle that extra ecclesiam nulla salus (outside the church there is no salvation). Therefore, Jesuits viewed the Protestant missionaries as heretics under the shadow of death and destined for eternal damnation. For Jesuits and indeed for the entire Catholic Church of that time, being baptized into the Catholic Church was the only way to taste eternal salvation. Baptism into and membership of the Catholic Church was absolutely necessary for salvation. Without these two elements, one was condemned to eternal death. But the Protestant missionaries did not believe that baptism and membership into the Catholic Church were necessary for eternal salvation.

The other area of theology that divided Jesuits and Protestants was polygamy. In most Zambian communities, polygamy was accepted and divorce permitted on occasion, both of which were forbidden by the Roman Catholic Church. As such, for the Jesuits, the official attitude toward polygamy remained rather conservative, in line with the thinking of the universal Catholic teaching. This is why when someone who lived within the Christian village turned to polygamy, he or she was asked to leave the village. For the Jesuits, strict adherence to the practice of monogamy was sometimes perceived to be a sign that Catholics, as opposed to Protestants, were selective in terms of the people they attracted. One chief had this to say about Catholic missionaries:

Your religion is a true religion. The Protestants recruit all the undesirable characters and make them more insolent and thievish. One of our men was sent away from our village because of polygamy. He went to Kawimbe and after a few months he was baptized together with his wives. They accept anyone and they pick up all the weeds we throw over the hedge. ${ }^{49}$

49 Mponda-Mambwe, missionary diary 1891-95 (copy held at the Missionaries of Africa Archives in Lusaka, Zambia, and original diary said to be held at the White Father's Archives in Rome). 
Despite the conservative approach in the preservation of their Catholic tradition, Jesuits were perceived to be less negative than Protestants toward African customs, rites, and cultures. ${ }^{50}$ Moreau, for instance, participated fully in local customs and rites. He went to the shrine with people to pray for rain and attended funerals and initiation ceremonies that were carried out according to local customs. At one point, he even stated that he wished polygamous people could become practicing Catholics. In a letter to his superior, dated August 27, 1932, he had this to say:

Last Thursday there was a great gathering at Monze's grave [burial ceremony of the local chief], at least 1500 people. I went there myself and I preached to the crowd from a heap of stones. I told them that I thought my place was also to be with them, their joys as well as their sorrow. ${ }^{51}$

\section{A Comparative Statistical Analysis of the Success of Jesuit and Protestant Missionaries in Zambia}

The following analysis aims to assess the successes and failures of the Jesuit and Protestant missionaries. It indicates, at least tentatively, that Jesuit missionaries had greater success than Protestant missionary societies in spreading the message of Christ. This is evident in the numbers converted, as well as the number of institutions they established, such as schools, parishes, hospitals, agricultural centers, social justice institutions, youth training centers, cultural institutions, and human rights and social apostolates, among other things. Thus, while Protestant missionaries were the first to establish mission stations in Zambia, Catholic missionaries, especially the Jesuits who established their missions at a later date, appear to have superseded Protestant influence by the mid-twentieth century. Early Jesuit missionaries were highly involved in a variety of apostolates, which demonstrates how far and wide they went to attract the local population. At the beginning of the twentieth century, in the Southern Province alone, there were no fewer than eight Protestant missionary groups, yet the Jesuits were able to cover more ground and population than these varied groups.

\footnotetext{
5o Hastings, Church in Africa, 197.

51 Moreau to superior, letter dated July 19, 1932 (copy held at the Jesuit Archives in Lusaka, Zambia, Box A1).
} 
Covering much ground does not, of course, necessarily entail success. However, in the case of the Jesuit missionaries, they did not just cover considerable ground; they also attracted a large number of converts. According to the 1924 GMC of Northern Rhodesia held in Kafue between June 9 and 15, there were about eighteen thousand baptized Zambians from fourteen Protestant missions, while there were forty-five thousand baptized Zambians who belonged to the Catholic Church. ${ }^{52}$ The dominance of Catholicism has continued up to more recent times. In a survey by the Evangelical Fellowship of Zambia in 1994, Lusaka, the capital city, registered the following results:

Catholic attendance on a Sunday was 102,065 (10.39\% of Lusaka's total population). Attendance at churches belonging to Evangelical Fellowship of Zambia was $37,563(3.61 \%)$; at Christian Council churches 16,582 (1.66\%); for the SDA 12,183 (1.24\%); for New Apostolic Church 25,882 $(2.63 \%)$, and at Independent Churches a mere 5,939 (0.58\%). There is another category of Sunday Churches which originate from or are related to overseas churches, with attendance of 12,192 (1.24); presumably, this consists mainly of Jehovah's Witnesses. Thus Catholics are by far the most dominant. ${ }^{53}$

By 1924, there were about seven thousand Catholics within the Jesuit missions, and eighty-three schools with 4,300 registered children. ${ }^{54}$ By 1964, Jesuits managed 168 primary schools. And while primary schools run by different church organizations were all given to the government upon the country's independence, "in mid-1994, there were still forty-one church secondary schools, twenty-seven run by Catholics, five by UCZ, four by the Brethren in Christ, two by the Anglican Council, and one each by the sDAs, the Evangelical Church in Zambia, and other autonomous church body."55

The Jesuits created almost all of the parishes in Southern, Central, and Lusaka Provinces and many more in other parts of the country before handing them over to the local leadership and to other Catholic religious congregations. Similarly, the number of baptized Christians in areas managed by Jesuits was and is still much higher compared with all Protestant groups. Today, the

52 Proceedings of the General Missionary Conference of Northern Rhodesia, Kafue: gth June to 15th (Cape Province: Lovedale Institution Press, 1925), 86.

53 Paul Gifford, African Christianity: Its Public Role (London: Hurst, 1998), 187.

54 Snelson, Educational Development in Northern Rhodesia, 89.

55 Gifford, African Christianity, 189. 
Catholic Church in Zambia is the largest Christian denomination, with about thirty percent of the population.

There are several reasons for the greater degree of success of the Jesuit missionaries in comparison with the Protestant missionaries. First, when Protestants arrived in the area, they encountered a number of obstacles and made a number of mistakes. When the Jesuits arrived, they were able to capitalize on these mistakes by learning from the failures of the Protestants. In his discussion of the factors behind the Catholic missionaries' success, Beetham points out that Catholics began their mission when medicines for tropical diseases were being discovered. As such, there were fewer deaths this time around, and they were also able to attract new recruits from Europe. The re-introduction of Propaganda Fide as a central body coordinating and supporting Catholic missionary efforts was also highly significant: "In contrast to the larger Protestant societies, the responsibility of many of the Catholic orders was limited to Africa and [specifically], to particular regions in Africa. This made possible a greater concentration of resources," says Beetham. ${ }^{56}$

\section{Conclusion}

While the focus of this chapter has been on the different approaches to evangelization as employed by Jesuits and Protestants in Zambia, and the competition and rivalry between them, it is worth concluding on a more positive note by pointing out that there was a great amount of cooperation, coordination, and collaboration as well, with some cordial and mutual relationships between individual missionaries from across the denominational boundaries. As was mentioned, in the initial stages of the GMC, Jesuits declined to participate and thus conflicts between them and the Protestants could not be resolved easily. But in the later stages, the Jesuits opted to be part of the conference, giving rare evidence of institutional, not simply individual, collaboration. This move led to some dialogue among the different groups, which reduced the level of competition and rivalry.

Another example of Jesuit-Protestant collaboration was that which took place between Torrend, a Jesuit, and John R. Fell (1879-1947) of the Kafue Institute, in proofreading a translation of the Bible into the Chitonga language in April $1927 .{ }^{57}$ In another example, when Moreau, the Jesuit, was stranded with his goods at a rail station, it was Anderson, the SDA missionary, who

$5^{6} \quad$ Beetham, Christianity and New Africa, 15-16.

57 Ibid., 45 . 
bailed him out, and when Moreau fell from the back of a horse, it was again Anderson who treated and cared for him. These examples stress the fact that inasmuch as strife existed between Jesuits and Protestants in Zambia, these missionaries also helped each other in moments of need.

\section{Bibliography}

Baur, John. 2000 Years of Christianity in Africa. 2nd ed. Nairobi: Paulines Publications Africa, 2009.

Beetham, T.A. [Thomas Allan]. Christianity and the New Africa. London: Pall Mall Press, 1967.

Bentley, Holman W. Pioneering on the Congo. 2 vols. New York: Fleming H. Revell, 1900.

Berman, Edward H., ed. African Reactions to Missionary Education. New York: Teachers College Press, 1975.

Bolink, Peter. Towards Church Union in Zambia: A Study of Missionary Co-operation and Church Union Efforts in Central-Africa. Franeker: T. Wever, 1967.

Carmody, Brendan. "Conversion to Catholicism in Zambia: 1891-1924." Missiology: An International Review 27, no. 2 (1999): 195-209.

Carmody, Brendan. Education in Zambia: Catholic Perspectives. Lusaka: Bookworld, 1999 .

Collins, Bernard. Lusinizyo. Lusaka: Commercial Press, 1958.

Gifford, Paul. African Christianity: Its Public Role. London: Hurst, 1998.

Groves, C.P. [Charles Pelham]. The Planting of Christianity in Africa. London: Lutterworth Press, 1958.

Hastings, Adrian. The Church in Africa: 1450-1950. Oxford: Clarendon Press, 1994.

Hinfelaar, Hugo F. History of the Catholic Church in Zambia. Lusaka: Bookworld, 2004.

Isichei, Elizabeth. A History of Christianity in Africa from Antiquity to the Present. Lawrenceville, NJ: Africa World Press, 1995.

Lane, William. Jesuits in Zambia: 1880-1991. Lusaka: Ndola Mission Press, 1991.

Livingstone, David. Missionary Travels and Researches in South Africa. London: Ward, Lock \& Co., 1857.

McGivern, Thomas, and Mary O'Brien. Diocese of Monze: A Digest History 1905-2005. Edited by Joseph Braun. Monze: Diocese of Monze, 2005.

Monk, William, ed. Dr. Livingstone's Cambridge Lectures. Cambridge: Deighton Bell, 1860.

Murphy, Edward P., ed. A History of the Jesuits in Zambia: A Mission Becomes a Province. Nairobi: Paulines Publications Africa, 2003.

Participatory Assessment Group. The Church's Contribution to Development in Zambia. Lusaka: The Group, 2000. 
Proceedings of the General Missionary Conference of Northern Rhodesia, 1922. Livingstonia: Mission Press, 1923.

Proceedings of the General Missionary Conference of Northern Rhodesia, Kafue: gth June to 15 th. Cape Province: Lovedale Institution Press, 1925.

Ragsdale, John P. Protestant Missions Education in Zambia, 1880-1954. London and Toronto: Associated University Presses, 1986.

Rotberg, Robert I. Christian Missionaries and the Creation of Northern Rhodesia: 18801924. Princeton: Princeton University Press, 1965.

Shaw, Mark R. The Kingdom of God in Africa: A Short History of African Christianity. Grand Rapids: Baker, 1996.

Smith, Drew R. "Missionaries, Church Movements, and the Shifting Religious Significance of the State in Zambia." Journal of Church and State 41, no. 3 (1999): 525-50.

Snelson, Peter D. Educational Development in Northern Rhodesia 1883-1945. Ndola: National Educational Company of Zambia, 1974.

Sundkler, Bengt, and Christopher Steed. A History of the Church in Africa. Cambridge: Cambridge University Press, 2000.

Westermann, Diedrich. Africa and Christianity. Oxford: Oxford University Press, 1937. 


\title{
Soror nostra es: Jesuits, Protestants, and Political Elites in Southern Africa among the Shona and the Ndebele, $1889-1900$
}

\author{
Aquinata Agonga
}

Historical archives overflow with nineteenth-century accounts of the heroic incursions of missionaries into the African hinterlands, equipped with minimal resources and even less knowledge about their destinations. Tales of young missionaries newly arrived in southern Africa, braving rain, rivers, treacherous paths, diseases, and unknown terrain along the Zambezi to lands lying in the deepest interior of the African continent can be found on shelves in libraries around the world. Along their paths, the missionaries built prayer hamlets that would constitute the foundations of one of the most enduring legacies of this missionary age.

Unfortunately for Africa, its missionary fate was largely instigated by Western colonialism and its aftermath, born of a series of events that marked the second half of the nineteenth century. ${ }^{1}$ Europe, experiencing the climax of industrialization, stood in dire need of markets for products and raw materials for production. The reports and narratives of Europeans returning home from short stints as explorers, hunters, traders, and missionaries in Africa about a continent as vast in mass as it was rich in resources fell on eager ears. ${ }^{2}$ Soon, European powers were stumbling over each other in their scramble for the continent. As political leaders sliced up the continent, European Christian authorities busied themselves with drawing parallel fault-lines along which they would plant the seeds of the Gospel.

The battle for a share of the continent and its resources was just as spiritual as it was political. The dramatic arrival of the missionaries in Matabeleland started as early as $1859 .^{3}$ Through Robert Moffat (1795-1883), the London Missionary Society (LMS) had sought to establish a mission station

1 Donald Denoon and Balam Nyeko, Southern Africa since 1800 (London: Longman Group, 1984), 117 .

2 Lewis H. Gann, A History of Southern Rhodesia: Early Days to 1934 (London: Chatto \& Windus, 1965), 18.

3 Ibid. 
in Matabeleland, then under Chief Mzilikazi (c.1790-1868), ${ }^{4}$ who, unlike Chief Khama III (c.1837-1923) of the Bamangwato, and for reasons other than genuine interest in the spiritual message his strange guests claimed to bear, allowed the missionaries to settle in the territory and train his people. ${ }^{5}$ The chief pledged to give them any help they needed as they went about their duties. He encouraged his subjects to listen to the strangers and often availed himself during the services held on Sundays. ${ }^{6}$

Although the chief participated in some of the activities of the early missionaries, he had his own reasons for welcoming them among his people, ${ }^{7}$ as he hoped to use the missionaries as trading agents with white South Africa and as a channel for the acquisition of more firearms. Once the missionaries had settled, he thought that they would then link him with white South Africa. ${ }^{8}$ In general, African chiefs had acquired firearms that needed maintenance and, as such, they saw an opportunity in the missionaries who would be able to carry out the needed repairs. ${ }^{9}$ For their part, the missionaries saw an opening and a chance to evangelize and convert the Africans. ${ }^{10}$

It was thus clear from the outset that both parties started on a wrong footing, as the missionaries had been granted leave to enter these territories for reasons other than those for which they had originally sought entry. Most chiefs were more interested in the gifts the missionaries brought along, as well as the services the missionaries were prepared to offer. The chiefs also opened up their territories on the misconceived idea that these strangers would give them protection in times of war.

The missionaries, like their colonial counterparts, possessed firearms that the chiefs required for wars. It is reported, for instance, that when Mzilikazi realized the threat posed to his chiefdom by the belligerent Zulu, or the powerful Boer armies, he dispatched his messenger, Mncumbata Khumalo

Mzilikazi (meaning the Great Road), was a south African king who founded the Matabele kingdom (Mthwakazi), Matabeleland, in what became Rhodesia and is now Zimbabwe. He was born near Mkuze, Zululand (now part of South Africa). He was the son of Matshobana, whom many had considered to be the greatest southern African military leader since the Zulu king Shaka (1787-1828, r.1816-28).

5 Sabelo J. Ndlovu-Gatsheni, "Who Ruled by the Spear? Rethinking the Form of Governance in the Ndebele State," African Studies Quarterly 10, nos. 2-3 (2008): 71-94, here 75.

6 Benedict V. Mtshali, Rhodesia: Background to Conflict (London: Leslie Frewin, 1968), 30.

$7 \quad$ Ndlovu-Gatsheni, "Who Ruled by the Spear?," 75.

8 Ibid.

9 Mtshali, Rhodesia, 3 .

10 Ngwabi Bhebe, Christianity and Traditional Religion in Western Zimbabwe, 1859-1923 (London: Longman, 1979), 27. 
(c.1780s-c.1872/73), to Kuruman with an invitation for Moffat. ${ }^{11}$ He viewed the missionaries as potential allies against his enemies, and he also sought to employ their services to improve trade relations with the outside world and to acquire superior arms. ${ }^{12}$ The chief and Moffat established an enduring friendship. Hugh Marshall reports that, on one occasion, the chief, while listening to Moffat's preaching, exclaimed, "I like you, I like you and you will be my father and I will call you by the name of my father Matshobane."13

The missionaries seem to have never suspected anything from the chiefs and their subjects other than pure interest in their message, simply assuming that the chiefs understood their mission and had a genuine desire for conversion. ${ }^{14}$ This failure to understand the motives behind the chiefs' invitations saw the missionaries toil for over twenty years without converting a single person..$^{15}$

The missionaries' encounter with Africa in the period after the Berlin Conference (1884-85) needs to be evaluated within its proper context. Missionaries affiliated to the two faith orientations arrived in Africa at the onset of what would become one of the most important events in the history of the continent, namely European colonialism. From the start, the encounter between Africa and colonialism was marked by suspicion, mistruths, hostility, and violence. ${ }^{16}$ The missionaries arrived at a time when revulsion for and suspicion of the white man were already hardening within Africa's collective consciousness. ${ }^{17}$ It did not help that the missionaries made little effort to dissociate themselves from the colonial authorities and in some cases ${ }^{18}$ actually rallied with the colonial forces in the many battles that Africa waged against the initial stages of colonialism. ${ }^{19}$

The remaining part of this chapter seeks to establish the relationship between the missionaries and the political administration among the Ndebele and the Shona in the period between 1880 and 1900 . The failure to convert even a handful of people in a decade pushed the missionaries into cooperating with the colonial administration in the fight against the Africans and their governments. The missionaries, perhaps out of frustration at the reluctance

\footnotetext{
11 Ndlovu-Gatsheni, "Who Ruled by the Spear?," 74.

12 Ibid.

13 Hugh Marshall Hole, Lobengula (London: Philip Allan \& Co., 1929), 12.

14 Robert Blake, A History of Rhodesia (London: Eyre Methuen, 1977), 27.

15 Julian Mockford, Seretse Khama and the Bamangwato (London: Staples Press, 1950), 44.

16 Ndlovu-Gatsheni, "Who Ruled by the Spear?," 80.

17 Mtshali, Rhodesia, 3 .

18 Ndlovu-Gatsheni, "Who Ruled by the Spear?," 81.

19 Jackson Mutero Chirenje, Chief Kgama and His Times, c.1835-1923: The Story of a Southern African Ruler (London: Rex Collings, 1978), 24.
} 
of Africans to convert or their own failure to understand the real motives behind the chiefs' eagerness to offer accommodation, ${ }^{20}$ gave their full support to the political elite under the British South Africa Company (BSAC) of Cecil Rhodes (1853-1902) as it sought to conquer and subdue the Ndebele. To the missionaries, both Catholic and Protestant, the chiefs had become obstacles to evangelization, and the colonial administration had become an ally in the process of eliminating those obstacles.

\section{Background}

The Catholic Church turned its attention to the Jesuits for the task of evangelizing the southern part of Africa. It chose to send its well-disciplined shock troop, as Jesuits were then perceived to be. ${ }^{21}$ The Jesuits themselves had a strong foundation in missionary work around the world, ${ }^{22}$ and, as Pope Pius VII (1742-1823, r.1800-23) would observe at the restoration of the Society in 1814, it would have been a disservice to the world if the church failed to employ the skilled rowers for the storm-tossed bark of Peter, whom the Society could provide. ${ }^{23}$ To the Jesuits, he gave a word of exhortation, urging them to be true to St. Ignatius of Loyola $(c .1491-1556)$, their co-founder, and to his legacy. ${ }^{24}$ As such, the Jesuits arriving in Africa were more than prepared for missionary work. ${ }^{25}$ However, the Jesuits encountered the same challenges as other missionaries. Their penetration into the interior was viewed as a threat to the lands and peoples that were controlled by African chiefs and, indeed, to the chiefs' own sovereignty.

There were different groups of Europeans arriving among the Ndebele and the Shona through what was then known as Bechuanaland, which is today's Botswana. These groups, which were motivated by a variety of interests, sought favors from the chiefs in different areas. Some came bearing gifts such as guns, beads, and drinks, while others, like the missionaries, came offering various skills as incentives. There were also hunters, miners, teachers, and politicians among the missionaries. These initial activities saw the chiefs and their

\footnotetext{
$20 \quad$ Mtshali, Rhodesia, 30.

21 Gann, History, 18.

22 William V. Bangert, A History of the Society of Jesus (St. Louis: Institute of Jesuit Sources, 1972), 429 .

23 Ibid.

24 Ibid.

25 Gann, History, $5^{8}$.
} 
subjects face a number of challenges in their attempts to understand what the strangers really wanted.

The royal kraals through which the missionaries sought access to African chiefdoms were essentially Africa's bastions of power against European invasion and, in fact, constituted the very repository of the customs that were the fabric that held these societies in place. ${ }^{26}$ The reigning African chiefs in whose kraals the missionaries arrived with the message of the Gospel were faced with difficult decisions: ${ }^{27}$ How could they determine the distinction between the missionary and the colonizer? Worse still, how could they admit foreigners who brought along a belief system that would ultimately end in the extinction of African customs? The foreigners thus posed a significant threat to their sovereignty. As Robert Blake aptly observes, for the African chiefs, leadership had never required so much wisdom. ${ }^{28}$

\section{The Missionaries in the Field}

The missionaries arriving in Africa assumed that black people were without religion ${ }^{29}$ and in need of salvation. ${ }^{30}$ As such, once the missionaries settled among the communities, they set out to teach the Africans the true religion with the aim of converting them. The remote probability that Africans had their own religion did not hold substance at all, and, to the missionaries, any concept of African religion was rooted in witchcraft and had to be done away with. ${ }^{31}$

The African chiefs, for their part, opened up their homes to the strangers in accordance with the African tradition of hospitality. As mentioned earlier, the Ndebele chiefs saw the arrival of the Christian missionaries as offering a means to pursue their own commercial interests and, particularly, their desire to acquire guns that were needed to defend the Ndebele state from every form of aggression. They also wanted access to missionary medicine and other modern goods and ideas. ${ }^{32}$ Mzilikazi and his successor Chief Lobengula Khumalo

\footnotetext{
26 Ibid.

27 Ndlovu-Gatsheni, "Who Ruled by the Spear?," 86.

28 Blake, History of Rhodesia, 27.

29 Sabelo J. Ndlovu-Gatsheni, "Beyond the Equator There Are No Sins: Coloniality of Being and Violence in Africa," Journal of Developing Societies 28, no. 4 (2012): 419-40, here 425.

3o Ibid.

31 Ibid.

32 Sabelo J. Ndlovu-Gatsheni, "Rethinking Religious Encounters in Matabeleland Region of Zimbabwe, 1860-1893," African Journal of History and Culture 1, no. 2 (2009): 16-27, here 20.
} 
$\left(1845^{-94}\right)^{33}$ were always very friendly to the missionaries, allowing them to live among their people, the Ndebele, and even giving them audiences on occasion. ${ }^{34}$ It was against this backdrop of chiefly hospitality that the Catholic Church sent its team of missionaries. The church turned its attention to the ancient mission fields on the Zambezi where the Jesuits had long laid a foundation for evangelization in the Kingdom of Monomotapa from as early as $1560 .{ }^{35}$ Having worked in Mozambique and Angola for close to two centuries before their suppression in 1773, the Jesuits had acquired credentials for missionary work in southern Africa and, after their order had been restored in 1814, the pope did not hesitate to send them back to that same field. The Jesuits arrived in the territory sometime in 1879, a few months after they had left Grahamstown in today's South Africa.

Chief Khama, who came of age at a time when his country was witnessing a huge influx of white foreigners, did not allow the Jesuits to settle in his territory. His father Sekgoma I (d.1875), though skeptical of the spiritual value of the white man's religion, had some regard for the education the missionaries offered and had sent little Khama, together with his brother and a few other relatives, to be educated by the LMS. ${ }^{36}$ Therefore, unlike the other chiefs the missionaries encountered, Khama was well informed about the affairs of the world and was well acquainted with the politics of colonization and of Christian evangelization.

Under their superior, Fr. Henri Depelchin (1822-1900), the Jesuit missionaries were faced with challenges ranging from poor knowledge of the land to a people who were highly indifferent to their religion. After Grahamstown, their first stop was Bechuanaland, where they had come close to establishing themselves in the pre-suppression period before abandoning the venture at the time of the suppression. ${ }^{37}$ In the interim, Protestant missionaries, specifically from the LMs, had moved in to fill the void. ${ }^{38}$ The Jesuits discovered that not only was Khama educated in the ways of the white man but that

33 The second and last king of the northern Ndebele people. Both names, in the Ndebele language, mean "the men of the long shields," a reference to the Ndebele warriors' use of the Zulu shield and spear.

34 Ndlovu-Gatsheni, "Who Ruled by the Spear?," 18.

35 Gann, History, 18.

36 Chirenje, Khama and His Times, 17.

37 Sidwell Mhaladi Gabatshwane, Introduction to the Bechuanaland Protectorate History and Administration (Botswana: Kanye, 1957), 47.

38 Jackson Mutero Chirenje, A History of Northern Botswana 1850-1910 (Rutherford: Fairleigh Dickinson University Press, 1977), 104. 
he also professed the Christian faith, having been baptized by the Protestant missionaries.

Despite being denied settlement, the Jesuits were received rather warmly by Khama, and this may have persuaded them not to despair. They trudged on northward, stopping next in Matabeleland, under the reign of Lobengula, who, unlike Khama, quickly allowed them to settle in the territory and train his people, ${ }^{39}$ although initially he insisted that he did not want them to stay permanently. Ten years later, after realizing the value of the activities that were being carried out by the missionaries, Lobengula gave the Jesuits ample land and allowed them to stay permanently. ${ }^{40}$

In 1887 , the Jesuits opened their first permanent mission at Empandeni under Peter Prestage, S.J. (1842-1907). ${ }^{41}$ Like their fellow missionaries under the LMS, the Jesuits did not succeed in converting a single person until $1893 \cdot{ }^{42} \mathrm{All}$ the missionaries attributed this failure to the governing system of the Ndebele. They had envisioned the conversion of a people held in bondage for a long time and were therefore surprised at the reluctance of the Africans to convert. ${ }^{43}$ Their initial surprise gradually turned into disappointment, and, as was indicated earlier, they attributed their failure to the chief at the heart of a system that, according to them, was cloaked in superstition and witchcraft. ${ }^{44}$ Once they had identified the stumbling block to their mission, they sought ways to destroy it.

According to Ngwabi Bhebe, Prestage claimed that "until the Matabeles are put down by brute force [...] they will never improve." 45 The missionaries had come to the conclusion that the only way to evangelize the Africans, particularly the Ndebele, was by destroying their system of governance. ${ }^{46}$ They thus welcomed the advent of white rule as a solution, as it implied the destruction of Lobengula and the conversion of his people to Christianity. ${ }^{47}$ Entailed in this approach was also the need for the missionaries to collaborate with the colonial powers. ${ }^{48}$ The Jesuits, true to the spirit of their co-founder and to the

39 Ndlovu-Gatsheni, "Who Ruled by the Spear?," 17-20.

40 Chengetai J.M. Zvobgo, A History of Christian Missions in Zimbabwe (Gweru: Mambo Press, 1996), 1.

41 Bhebe, Christianity and Traditional Religion, 29.

42 Ibid.

43 Ndlovu-Gastheni, "Who Ruled by the Spear?," 19.

44 Ibid

45 Bhebe, Christianity and Traditional Religion, 82.

46 Ibid., 82-83.

47 Zvobgo, Christian Missions in Zimbabwe, 1.

48 Ibid. 
apostolic zeal that was at the foundation of their Society, selflessly dedicated themselves to the mission, with far-reaching consequences. ${ }^{49}$

\section{Cooperation with the Political Elite}

As the missionaries realized they were not making any headway in the evangelization of the Africans, they came to the conclusion that there were Africans who had converted but who were reluctant to profess their faith in public due to the fear of being accused of witchcraft. They decided that such silent converts would require the protection of another form of government, which could be provided by the colonial elite. ${ }^{50}$ Commenting on the situation, Prestage said: "It is perhaps well that the crisis should come soon; as every year delays by those of this nation, who but for living under the present barbarous rule and debarred by their fear from embracing Christianity would otherwise become Christians. ${ }^{51}$ He further explained his failure to convert Africans in the following words:

Our failure at Empandeni was not owing to the unwillingness of the natives to learn, and even become Christians, but it was due to the overwhelming terror, engaged by the system of government, which seizes every native in the country, when it is a case of casting off their pagan customs to adopt the new system. ${ }^{52}$

It was this kind of disillusionment, resulting from their failure to make converts, that eventually led the missionaries to collaborate with the colonial powers to remove the rulers they considered an obstacle to their mission. ${ }^{53}$ Whether it was the intractable Khama, who had resisted the true Christian faith, which was Catholic as far as the Jesuits were concerned, or the astute but cunning Lobengula, who plotted to exploit the missionaries in order to enhance his royal power, or even the scheming Chief Moemba of the Tonga,

49 Véronique Wakerley, trans., Journeys beyond Gubuluwayo to the Gaza, Tonga and Lozi: Letters of The Jesuits' Zambesi Mission, 1880-1883, ed. Ray S. Roberts (Harare: Weaver Press, 2009), 147 .

5o Ndlovu-Gatsheni, "Rethinking Religious Encounters," 23.

$5^{1}$ Zvobgo, Christian Missions in Zimbabwe, 2.

52 Ndlovu-Gatsheni, "Who Ruled by the Spear?," 21.

53 Mtshali, Rhodesia, 3. 
who planned the murder of missionaries in order to inherit their possessions, all had to go in order to pave the way for the Gospel in Africa. ${ }^{54}$

While working with the Africans, the missionaries had noticed how the chiefs were feared and revered by their subjects. As such, they reasoned that it was out of this fear that they could not openly come out to join the missionaries. ${ }^{55}$ The missionaries concluded that they had to have a new form of governance in order to save poor Africans from their wicked rulers. In the process, Christian missionaries, both Catholic and Protestant, defamed African forms of worship, viewing them as signs of barbarity, and denounced Ndebele resistance to Western values and ideas. Having stayed in southern Africa without much success in converting the Africans to Christianity, Moffat had arrived at the conclusion that the Ndebele were nothing but an "army of warmongers [...]; a nation of murderers whose hand is against every man." He went on to describe them as "people who worshipped the god of war, rapine, beef-eating, beer-drinking and wicked." ${ }^{\prime 6}$ This view was taken a notch higher by Reverend David Carnegie (1864-1910) of the LMS in a prayer of 1889. In it, he specifically called for the destruction of the Ndebele kingdom, saying: "Oh! For liberty and freedom and a power to break the cords of this savage monarch! This done, then our mission will begin. It will be so until a new government is formed and just laws administered to the people." 57

In their frequent correspondence with their colleagues, both the Jesuits and the Protestants described the Ndebele kingship as a fount of absolute dictatorship and despotic government. ${ }^{58}$ In practice, they openly advocated for the destruction of the Ndebele kingdom as the only way to open up this part of the land to Western ideas and values, including Christianity. ${ }^{59}$ In cases where African protagonists were featured in the evangelization process, they were often vilified and viewed as an impediment to the mission, against whom the missionaries heroically battled. ${ }^{60}$

\footnotetext{
54 Wakerley,Journeys beyond Gubuluwayo, 165.

55 Frederic Perry Noble, The Redemption of Africa: A Story of Civilization, 2 Vols. (New York: Young People's Missionary Movement), 1:390-91.

$5^{6}$ Blake, History of Rhodesia, 22.

57 Holmberg Anderson, African Tribes and European Agencies: Colonialism and Humanitarianism in British South East Africa, 1870-1895 (Stockholm: Scandinavian University Books, 1966), 20.

58 Ibid., 22.

59 Ibid.

6o Chirenje, History of Northern Botswana, 17.
} 


\section{Collaboration between the Missionaries and the Political Elite}

The missionaries had learned some of the local African languages and had even translated some parts of the Bible into these languages. ${ }^{61}$ At the appropriate time, this would present an opportunity for them to work with both the colonial political elite and the indigenous African people, as they were well equipped to act as interpreters between the chiefs on the one hand and the colonial elites on the other as the two parties negotiated for political concessions. ${ }^{62}$

Rhodes, who acted on behalf of the BSAC, was anxious to work with the missionaries in order to avoid criticism from humanitarian groups in Britain and South Africa. ${ }^{63}$ As far as he was concerned, the collaboration would help him push for the company's agenda among the Ndebele and the Shona and, at the same time, keep away imminent threats from the Germans and the Boers. ${ }^{64}$ With their patience worn thin from the fruitless labors in Matabeleland, the missionaries were ready and willing to support a political takeover by a colonial political class. ${ }^{65}$

The company used the missionaries to push for its agenda to have exclusive rights to explore minerals in Matabeleland. ${ }^{66}$ Rhodes readily agreed to work with the missionaries of all faiths, promising them land and security in exchange for their cooperation and involvement with the company plans. He invited them to accompany the pioneer column as chaplains and to act as interpreters with the chiefs for concessions. ${ }^{67}$ Company representatives came to Lobengula with Reverend Charles D. Helm (1844-1915) of Hope Fountain Mission, an LMS agent, and John Moffat (1835-1918), son of Robert Moffat, as interpreters. ${ }^{68}$ It was Helm who succeeded in convincing Lobengula that what the company proposed was for the good of the Ndebele people. He managed to get Lobengula to put his fingerprint on the dotted line of the paper for the company to acquire sweeping and exclusive mining rights in Matabeleland and Mashonaland. These Protestant missionaries were thus party to the controversial Rudd Concession of 1888 . To the missionaries generally, this concession

\footnotetext{
$61 \quad$ Ibid.

62 Ndlovu-Gatsheni, "Who Ruled by the Spear?," 20.

63 Blake, History of Rhodesia, 74.

64 Mtshali, Rhodesia, 3 o.

65 Ndlovu-Gatsheni, "Who Ruled by the Spear?," 22.

66 Zvobgo, Christian Missions in Zimbabwe, 2.

67 W.D. [William Daniel] Gale, Heritage of Rhodes (London: Oxford University Press, 1950), 10.

68 Ndlovu-Gasteni, Rethinking Religious Encounter, 22.
} 
was seen as a major step in helping them evangelize among the natives. Once the BSAC had acquired the rights to move freely in Matabeleland, the missionaries saw their last chance to evangelize and hoped that they could help change the Africans. They aimed to acquire land to build schools, churches, and hospitals. The concession gave the company power to move freely in the whole of Matabeleland, which at the time included the land of the Shona that Lobengula claimed to have under his control. ${ }^{69}$

\section{Rising Tension}

Although Lobengula rejected the Rudd Concession, the agreement that supposedly created it was still enforced because of the support it received from the missionaries. Because of this support, humanitarian groups were duped into believing that all was well in southern Africa. For their part, Africans could no longer separate the role of the missionaries from that of the colonialists, and the relationship between the whites and the Africans became strained, eventually culminating in the First Ndebele War of $1893 .{ }^{70}$ Commenting on the intensifying tension, Prestage stated: "Sacrificing one's life for religion is one thing, and it is to be hoped that there would be no fear on that score; but to be assegaid merely for being a white man is quite another thing and no man in sound reason can wish for that."71 The missionaries left their stations and joined the armies to put down the rebellion while other Europeans sought their own safety as the company pushed its army to suppress the rising. They were not ready to let go of what they had acquired with the support of the missionaries. At the height of the war, some of the missionaries felt a sense of remorse. As Bishop George W.H. Knight-Bruce (1852-96) of the Anglican diocese of Bloemfontein observed: "These days we think a great deal about the king and his people. Often, I begged to see the Matabele power broken but now when it is come to pass I feel very sore at heart. And yet I believe it's all for the best." 72

Despite such sentiments, however, the missionaries continued to support Rhodes's BSAC. Prestage wrote to his superiors regarding Rhodes's efforts to gain a foothold north of the Limpopo:

\footnotetext{
69 Gale, Heritage of Rhodes, 11.

70 Ibid.

71 As quoted in Zvobgo, Christian Missions in Zimbabwe, 2 (italics added).

72 Zvogbo, Christian Missions in Zimbabwe, 7.
} 
Our hope is that this company will bring about the downfall of this Matabele tyranny and the entrenchment of a more righteous government [...]. Now there is a fair prospect of a peaceful adjustment of differences, a gradual bringing of the land under kindlier influences, and a speedy cessation of this fiendish raiding. ${ }^{73}$

\section{Working Together}

After the Ndebele War, Matabeleland came under white occupation, which created an opening for the missionaries in Africa. ${ }^{74}$ Writing to Henry Schomberg Kerr, S.J. (1838-95), Prestage, who had witnessed the raid of the Ndebele and had special interest in the fall of their state, explained:

Our failure at Empandeni was not owing to the unwillingness of the natives to learn and even become Christians but was due to the overwhelming terror engendered by the pagan system of government [...]; any native relinquishing the ways of his forefathers is branded a traitor and is a marked man doomed to be knocked on the head as the cause of ill, should any misfortune attend his family or the town where he is residing. This is the barrier to missionary enterprise in Matabeleland. I foresaw it before I went to Empandeni but I always hoped that someone would have the grace to break it down. ${ }^{75}$

Prestage was fully behind the government and gave it his total support, acknowledging to the government representative, Dr. Leander S. Jameson (1853-1917), that "the church gave her blessing to the contemplated punishment of the pagan chiefs." To him, the "government's involvement and crushing of the Ndebele state was the only satisfactory solution." 76 The Ndebele system of government was a system of iniquity and deviltry, he remarked, and when asked if he would telegraph his views that the Ndebele government had to be overthrown to Rhodes, he readily agreed, stating that the destruction of the Ndebele system of government was the only way to ensure the security of life and property of whites and blacks in Mashonaland. In August 1891, he

$\begin{array}{ll}73 & \text { Ibid., 8. } \\ 74 & \text { Ibid., 6. } \\ 75 & \text { Ibid., 7. } \\ 76 & \text { Ibid. }\end{array}$


wrote that "we must put down the Matabeles and then go on with our work as if nothing had happened and the sooner this happened, the better."77

\section{Collaboration on the Battlefield}

At one point, the missionaries were called upon to work with the company troops on the battlefield against the Ndebele. Fr. Marcus Barthelemy (18571913), for example, accompanied the troops as the chaplain during the campaign. ${ }^{78}$ In April 1893, he was assigned to Captain George Brand's patrol to the Gwanda District and was with them when they ran the gauntlet through the rebel impis (Ndebele soldiers or regiment) on the Tuli Road. ${ }^{79}$ At TabaZiKa Mambo, he assisted in carrying the wounded into the camp and comforted the dying from the government side. He also served under Colonel Herbert Plumer's (1857-1932) column in the Matopos. ${ }^{80}$

The Anglican missionaries had the Reverend Douglas Pelly (1865-1943) minister to the troops during the same campaign, and he was later appointed Anglican chaplain to the troops that left Salisbury for Bulawayo. On April 19, 1896, Pelly and the troops reached Fort Charter, where they found nearly all the troops from Makoni's district waiting to join. ${ }^{81}$ Here, the Wesleyan Methodist missionaries under Isaac Shimmin (1860-1947) were supporters of the BSAC and in favor of the company taking over Lobengula's territory. ${ }^{82}$ They were in total agreement with Prestage, the Jesuit, on the need to fight and destroy the Ndebele. ${ }^{83}$

In a letter to Reverend Hartley Marshall (1868-1928) of the Wesleyan Methodist Missionary Society, Shimmin emphatically reasoned that to hesitate fighting the Ndebele would pose a grave danger to the lives of the whites in Mashonaland if the Ndebele themselves were to return and fight. ${ }^{84}$ According

$77 \quad$ As cited in ibid.

78 Francis Richartz, S.J., "Chishawasha Today," Zambesi Mission Record 1, no. 14 (1901): 471-75, here 474 .

79 Bhebe, Christianity and Traditional Religion, 87.

80 Ibid.

81 Zvogbo, Christian Missions in Zimbabwe, 28.

82 H.O. Briggs, "New Development in Mashonaland and Matabeleland and the African Response to Christianity 1897-1918," 67, available online http://journals.co.za/docserver/ fulltext/zambezia/1891-1945/1/303.pdf?expires=1492096428\&id=id\&accname=guest\&che cksum=136A38F8ECoA8822742E19E105996CD6 (accessed April 13, 2017).

83 Gann, History of Southern Rhodesia, 18.

84 As cited in Zvogbo, Christian Missions in Zimbabwe, 27-28. 
to Shimmin, most whites, including missionaries, supported the need to fight the Ndebele:

I have spoken with hundreds of men and have heard from everyone the same opinion expressed that the Matabele question must be settled once and by force. On this point, the clergyman and the farmer, the English and the colonial are at one and however much we dread the horrors of warfare, in a case of this sort, it is the better choice of two evils..$^{85}$

At this point, the missionaries from all sides of the faith worked together with the understanding that they had a common enemy in the African chiefs. They would say soror nostra es to each other as a way of encouraging themselves in the mission they had undertaken ${ }^{86}$ that is, to fight on the side of the political elite against the African chiefs. ${ }^{87}$ The LMS agent, William Elliot (1865-1944), saw the victory of the colonial forces over the Ndebele as God's punishment on them for their past atrocities upon other black people. ${ }^{88}$

The BSAC under Rhodes kept its promise to give assistance in the form of security, land, grants, and financial support to the various missionary groups ready to work in the land. ${ }^{89}$ Shimmin viewed this as an opportunity for change and a chance of a lifetime to set up a mission station in Matabeleland. ${ }^{90} \mathrm{He}$ asked Rhodes for favors even before they had succeeded in putting down the Shona War of 1896-97, requesting that the company grant him and his mission stands in the townships in Matabeleland for church purposes, farms for mission work, and an additional grant of a hundred pounds per year for five years. ${ }^{91}$ While writing home about his meeting with Rhodes, he claimed:

To this entire matter, he immediately agreed and promised to send me a formal letter $[\ldots]$. He went on to say that he made this promise willingly and with great pleasure as he regarded mission work as one of the best means for opening up and civilizing a country and that he had already

\footnotetext{
85 As quoted in ibid., 8.

86 Latin for "thou art our sister"; from Genesis 24:6o "They blessed Rebekah, and said unto her, Thou art our sister, be thou the mother of thousands of millions, and let thy seed possess the gate of those which hate them."

87 Richartz, "Chishawasha Today," 474.

88 Zvogbo, Christian Missions in Zimbabwe, 9.

89 A. [Anthony] J. Dachs and W.F. [William Francis] Rea, The Catholic Church and Zimbabwe 1879-1979 (Gwelo: Mambo Press, 1979), 52-54.

$90 \quad$ Zvogbo, Christian Missions in Zimbabwe, 11.

91 Ibid., 4 .
} 
received convincing proofs of the good accomplished by the Wesleyan Church in Mashonaland. ${ }^{92}$

In March 1894, Rhodes instructed the BSAC administrator to inform Shimmin in writing that the company would grant the Wesleyans a subsidy of one hundred pounds annually for five years for their new mission in Matabeleland, as well as such land as might be required for mission work. ${ }^{93}$ It was not to the Wesleyans alone that such favors were advanced by the company. In the same year, Rhodes granted the missionaries of the Seventh-day Adventist Church a twelve thousand-acre farm at Solusi, and in 1895, the LMS were given twentyfour thousand acres of land at Dombodema. For his part, the Anglican bishop of Bloemfontein had been advocating for the establishment of a British protectorate over the Shona in order to protect them from what he understood to be inhuman cruelties meted on them by the Ndebele. When appointed to take charge of the new diocese, he went to Jameson, the administrator, to discuss the issue of land for Anglican missions. ${ }^{94}$ Rhodes honored his commitment and instructed the company to give the Anglicans six hundred British pounds for the expenses of Anglican missions in Mashonaland. ${ }^{95}$

The Jesuits were not forgotten in this colonial distribution of the spoils. Their first interest had been to acquire land and, toward this end, Rhodes ordered Archibald Colquhoun (1848-1914), the first administrator of the newly acquired territory, to give them every help. The administrator wrote: "Father Prestage tells me that Father Hartmann's knowledge regarding the ground suitable for a mission station is rather limited but no doubt, Mr. Heaney or one of the pioneers will give him help and advice in this matter as required."96 What Andrew Hartmann, S.J. (1851-1920) settled for was not good enough according to Prestage, for when he arrived after the second inspection, he found a better site beyond the boundaries they had been assigned. An exchange was arranged with the BSAC to take over the Chishawasha Valley. ${ }^{97}$ In recognition of their services, the company gave the Jesuits a farm consisting of twelve thousand acres of land. It was on this land that the Chishawasha Jesuit mission was founded. ${ }^{98}$

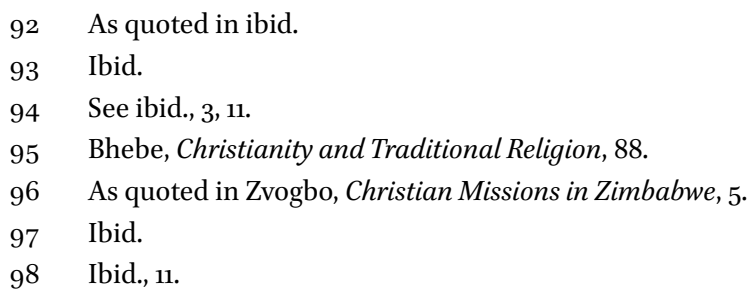




\section{The Missionary Settlement and Work on the Land}

The development of the Chishawasha mission was remarkable. The missionaries derived pleasure and gratification from their success at the farm, and it became an attraction that brought all the prominent people in Salisbury to visit. ${ }^{99}$ Commending the good work done by the Jesuits at Chishawasha, Colonel Frank W. Rhodes (1858-1902) had this to say: "The Jesuits have deserved well of Rhodesia and the Chartered Company. Take Chishawasha alone: what an advertisement Chishawasha has proved to the Chartered Company, the show place of Rhodesia." ${ }^{100}$ The farm provided the model beneficial Victorian expansion; this opened doors in the company that the Jesuits put to use whenever there was need to.

Once settled in their daily duties of social ministry and teaching, the Catholic missionaries also performed some tasks for the BSAC, which had become the official administrative authority among the Shona and the Ndebele. ${ }^{101}$ For example, the administration made an arrangement whereby the people would pay their taxes to the indunas (councilors or headmen) but collect the receipt from the missionaries.

\section{Conclusion}

Having come with a plan to preach and convert the Africans, the missionaries perceived the African way of life as heathen and treated everything African with contempt. They strove to convert the Ndebele in the usual way by preaching the Gospel to them. Yet despite the intensified missionary activities in the area, there were very few converts between 1870 and 1889 , and the missionaries came to the conclusion that their main obstacle was the governance system and that the system had to be replaced. They recognized that a different kind of governing system was required to win over the Africans, and so when the BSAC came calling and seeking their assistance, they were more than willing to offer help. Here we come across an interesting case of encounter between Jesuits and Protestants, which was brought about by their need to collaborate with the colonial elites in order to remove African indigenous leadership. Moreover, once they had identified the need they had for each other, the missionaries and the colonial elites came together and established informal alliances. Whereas

\footnotetext{
99 Ibid., 13.

100 Ibid.

101 Dachs and Rea, Catholic Church and Zimbabwe, 42.
} 
the missionaries established an alliance with the BSAC out of the belief that it would bring about the much-needed change for evangelization, the company wanted an alliance that would shield them from criticism by humanitarian groups back home. In the end, the resolve to depose African chiefs, and the facilitation of colonial elites toward that goal, turned the Jesuits and Protestants into "sisters" within the African missionary terrain.

\section{Bibliography}

Anderson, Holmberg. African Tribes and European Agencies: Colonialism and Humanitarianism in British South East Africa, 1870-1895. Stockholm: Scandinavian University Books, 1966.

Bangert, William V. A History of the Society of Jesus. St. Louis: Institute of Jesuit Sources, 1972.

Bhebe, Ngwabi. Christianity and Traditional Religion in Western Zimbabwe, 1859-1923. London: Longman, 1979.

Blake, Robert. A History of Rhodesia. London: Eyre Methuen, 1977.

Briggs, H.O. "New Development in Mashonaland and Matabeleland and the African Response to Christianity 1897-1918." http://journals.co.za/docserver/fulltext/ zambezia/1891-1945/1/303.pdf?expires $=1492096428 \&$ id $=i d \&$ accname=guest\&chec ksum=136A38F8ECoA8822742E19E105996CD6 (accessed April 13, 2017).

Chirenje, Jackson Mutero. Chief Kgama and His Times, c. 1835-1923: The Story of a Southern African Ruler. London: Rex Collings, 1978.

Chirenje, Jackson Mutero. A History of Northern Botswana 1850-1910. Rutherford: Dickinson Fairleigh University Press, 1977.

Dachs, A. [Anthony] J., and W.F. [William Francis] Rea. The Catholic Church and Zimbabwe 1879-1979. Gwelo: Mambo Press, 1979.

Denoon, Donald, and Balam Nyeko. Southern Africa since 180o. London: Longman Group, 1984.

Gabatshwane, Sidwell Mhaladi. Introduction to the Bechuanaland Protectorate History and Administration. Botswana: Kanye, 1957.

Gale, W.D. [William Daniel]. Heritage of Rhodes. London: Oxford University Press, 1950. Gann, Lewis H. A History of Southern Rhodesia: Early Days to 1934. London: Chatto \& Windus, 1965 .

Hole, Hugh Marshall. Lobengula. London: Philip Allan \& Co., 1929.

Mockford, Julian. Seretse Khama and the Bamangwato. London: Staples Press, 1950.

Mtshali, Benedict V. Rhodesia: Background to Conflict. London: Leslie Frewin, 1968.

Ndlovu-Gatsheni, Sabelo J. "Beyond the Equator There Are No Sins: Coloniality of Being and Violence in Africa." Journal of Developing Societies 28, no. 4 (2012): 419-40. 
Ndlovu-Gatsheni, Sabelo J. "Rethinking Religious Encounters in Matabeleland Region of Zimbabwe, 1860-1893." African Journal of History and Culture 1, no. 2 (2009): 16-27.

Ndlovu-Gatsheni, Sabelo J. "Who Ruled by the Spear? Rethinking the Form of Governance in the Ndebele State." African Studies Quarterly 10, nos. 2-3 (2008): 71-94.

Noble, Frederic Perry. The Redemption of Africa: A Story of Civilization, 2 vols. New York: Young People's Missionary Movement.

Richartz, Francis S.J. “Chishawasha Today." Zambesi Mission Record 1, no. 14 (1901): 471-75.

Wakerley, Véronique, trans. Journeys beyond Gubuluwayo to the Gaza, Tonga and Lozi: Letters of The Jesuits' Zambesi Mission, 1880-1883. Edited by Ray S. Roberts. Harare: Weaver Press, 2009.

Zvobgo, Chengetai J.M. A History of Christian Missions in Zimbabwe. Gweru: Mambo Press, 1996. 


\title{
Jesuit Portraits of Protestant Missionary Activity in Southern Africa in the Nineteenth and Twentieth Centuries
}

\author{
Wilfred Sumani, s.J.
}

The interaction between Jesuits and Protestant missionaries in Africa, particularly in the Zambezi Mission, was more complex than is often assumed. While relations between the two missionary bodies are usually described as "bitter" or "rivalrous," and their approaches to missionary work as diametrically opposed, a more careful analysis suggests that this is an oversimplification. This chapter draws upon the writings of Jesuits who worked in southern Africa in the late nineteenth and early twentieth centuries with the aim of painting a more balanced picture of the Jesuit perception of Protestant missionary work in the region. As we will see, not all of the Jesuit missionaries' writings present the Protestants in the same light: while some Jesuits describe Protestant missionary activity in negative and antagonistic terms, others were much more positive. To make sense of these differences, the chapter identifies a range of factors that may have informed the opinions of the Jesuit authors who wrote about the Protestant missionaries, including their closeness to the Protestants (dialogue of life), their hands-on missionary experience (missionary wisdom), and the interests of those writing the reports (motivation). Overall, the chapter argues that Jesuits and Protestants faced the same challenges and suffered similar losses, anxieties, and frustrations in their missionary ventures.

\section{Brief Historical Background to the Jesuit Presence in Southern Africa}

The nineteenth century witnessed the "second coming" of Jesuit missionaries to southern Africa (extending, for the most part, to present-day South Africa, Zimbabwe, and Zambia). Two centuries earlier, the Portuguese Jesuit Gonçalo da Silveira (1526-61) had sacrificed his life in the then Monomotapa Kingdom, earning himself the title of the "proto-martyr" of southern Africa. However, by the time Jesuits returned to Africa in the nineteenth century, Protestant missionaries had already crisscrossed the continent, especially the southern 
part, establishing a number of mission stations in their wake. Georg Schmidt (1709-85), of the Moravian Church, who was the first Protestant missionary to arrive in South Africa in 1737, established a mission among the Khoikhoi. Other Protestants arrived in southern Africa and established mission stations in the interior a few decades later. Dr. Robert Moffat (1795-1883) opened a mission station at Kuruman (seven hundred miles from Cape Town) in 1810, thirty years before David Livingstone's (1813-73) visit to the area. Livingstone, a representative of the London Missionary Society (LMS), reached the Great Lakes in 1866. By 1870, another LMS missionary, John Boden Thomson (1841-78), had established a mission at Hope Fountain in present-day southern Zimbabwe, ${ }^{1}$ and Reverend Thomas Morgan Thomas (1828-84), also of the LMS, had established a mission in Matabeleland.

The Society of Jesus was initially reluctant to engage in missionary work in southern Africa. When they eventually arrived in the region to establish St. Aidan's College at Grahamstown in the Eastern Cape Province (South Africa), the general consensus was that they had arrived too late. In the words of Alfred Weld, s.J. (1823-90):

Not only has the region which lies south of the river been traversed in all directions; not only is it travelled over annually by trading and hunting parties; but for many years past, we grieve to say it, Protestant missionaries have been peaceably pursuing their avocation in the heart of this vast district. Wesleyans, Presbyterians, and London missionary agents have for years resided with security in the land which we seem to be only now discovering to be a field ripe for the Gospel. The truth is, we are too late. ${ }^{2}$

The Protestant churches had acquired vast tracts of land and created mission territories for which they held exclusive evangelization rights. The Jesuits thus found themselves obliged to go into the interior of southern Africa to scout for "virgin soil" not yet exposed to the influences of Protestants, Muslims, and white traders. Plans to advance to Lake Nyasa were abandoned because of the likelihood of competition from the Free Church Mission, which had already established itself in the area. ${ }^{3}$ The Jesuits also failed to establish a mission at

1 Iris Clinton, Hope Fountain Story (Bulawayo: Mambo Press, 1969), 13-14.

2 Alfred Weld, Mission of the Zambezi (London: Burns and Oates, 1879), 34.

3 In fact, when Bishop James Ricards (1828-93) wrote to Fr. Weld asking the Jesuits to open a Jesuit mission in southern Africa, Ricards had in mind the area of Lake Nyasa (present-day Malawi). Weld initially thought it was a good idea, especially given that some slaves from the neighborhood of Lake Malawi had been rescued in a Catholic orphanage in Bombay and 
Shoshong (in present-day Botswana) due to the refusal of Khama III, chief of the Mangwato (c.1837-1923, r.1872-73, 1875-1923), to welcome them in his territory. The LMS had already established itself in this area and, in the king's estimation, there was no need for more "teachers"; 4 the king also warned the Jesuits that, though the Protestants had worked in the territory for more than twenty years, they had not enjoyed much success because the people were not disposed to Christianity. ${ }^{5}$

The Jesuits in southern Africa interacted with Protestants at various levels, as can be seen in the remarks made about Protestants in the diaries or articles of the Jesuit missionaries who worked in the Zambezi Mission. Some of the remarks about Protestants are positive, while others are disparaging, and they need to be read in their broader context.

\section{Casting a Shadow on Protestant Missionary Work}

\section{Richard Sykes, s.J.}

Richard Sykes, S.J. (1854-1920) was among the Jesuits who commented on the Protestant presence in southern Africa. Born in Lancashire, Sykes joined the Society of Jesus at Roehampton in 1874 and was ordained on September 25, 1887. In 1896, after serving as prefect-general and rector of St. Francis Xavier in Liverpool, he was appointed superior of the Zambezi Mission. He later became prefect apostolic of the same mission. In 1904, he was named provincial of the Society's English province. After his mandate, he returned to South Africa, where he died in 1920.6

Sykes wrote a number of articles about Protestant missionary activity in Africa. In one of his articles, published in the inaugural issue of the Zambesi

were willing to return to Malawi and bring Christianity to their fellow Africans. These, Weld thought, would make good interpreters. However, the idea was eventually dropped because the area was already occupied by the Free Church Mission. See Anthony J. Dachs and William F. Rea, The Catholic Church and Zimbabwe (Gwelo: Mambo Press, 1979), 17.

4 See Rob S. Burrett, "The Zambezi Mission and the Residences of Good Hope and Immaculate Heart of Mary, Old Tati," Botswana Notes and Records 32 (2000): 25-38, here 27-28. Chief Khama, who was converted to Christianity by the London Missionary Society, is said to have been a "deeply committed Christian known for his uprightness." Edward P. Murphy, s.J., "First Zambesi Mission," in A History of the Jesuits in Zambia: A Mission Becomes a Province, ed. Edward P. Murphy, S.J. (Nairobi: Paulines Publications Africa, 2003), 6o-86, here 68.

5 See Henri Depelchin, "From Tati to Gu-Bulawayo," in Diaries of the Jesuit Missionaries at Bulawayo 1879-1881, Rhodesiana Society 4 (Bulawayo: Mardon Printers, 1974), 9-16, here 15.

6 “Obituary, Fr. Richard Sykes, s.J.," Tablet (May 15, 1920): 15. 
Mission Record (ZMR) in March 1898, Sykes claimed that the Protestants had been able to outpace the Catholics in evangelizing African peoples partly due to generous financial donations from Protestant communities in Europe and America. Citing the Times for January 15, 1897, he notes that in "the past year the total income of the Protestant Missionary Societies throughout the world

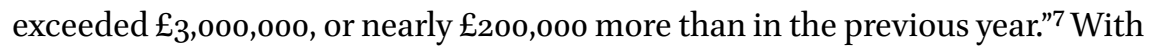
their huge sums of money, Protestants

are thus enabled to purchase large tracts of land, to which they have exclusive right in law, and on which therefore no Catholic missioner can settle without their sanction [...]. They can prejudice the natives for miles and miles round against Christianity and render it difficult work for the Catholic missioner to make headway amongst them. ${ }^{8}$

Sykes viewed this as unacceptable because the Protestants were teaching a "mutilated form of Christianity" based on "inconsistent doctrines" that were sure to bring Christianity into ridicule, thereby making it difficult for Catholics to preach the "truth." In his view, even though they claimed to be Christian, Protestant churches were "religions of human origin"9 that lacked claim to universality.

On the contrary, Sykes subscribed to the imperialistic vision of Catholicism and challenged Englishmen not to be "Little Englanders" but to "look with pride upon a Greater Britain beyond the seas and upon an empire upon which

7 This Protestant generosity stood in stark contrast to what he viewed as the miserliness of Catholics, with Sykes claiming that Catholics throughout the world had only managed to contribute around $£ 250,000$ to missionary work in Africa during the same period.

8 Richard Sykes, "Protestant Missionary Activity in South and Central Africa," Zambezi Mission Record [hereafter ZMR] 1, no. 1 (1898): 11-15, here 13. Sykes makes a similar point in another contribution to the journal. While thanking benefactors for their contributions to missionary activity in the world, he reminds all to take into consideration that these contributions compare "only unfavorably with the immense sums given for the conversion of the heathen by the Protestant bodies, especially of the United States and England." Richard Sykes, "The Missioner's Debt," ZMR 5, no. 63 (1914): 15-19, here 17-18. Bishop Anthony Gaughran, O.M.I (1849-1901), then vicar of the Orange Free State, also attests to the strained relationships between Catholics and Protestants. In an interview accorded to The Tablet, he reports that, in Griqualand, Catholic missionaries attracted a following among the local people and began to instruct the natives. However, Calvinists, who had been in the country since 1833 , came and opposed the work of the Catholics. The opposition resulted in the loss of enthusiasm on the part of the natives; see "An Interview with a South African Bishop," Tablet (September 22, 1888): 26.

9 See Sykes, "Protestant Missionary Activity," 14. 
the sun never sets."10 The metaphor of the "Greater Britain" was thus transposed onto the universality of the Catholic Church in an effort to draw more donations from Catholics in England. An article in The Tablet later approvingly cited Sykes's imperialistic outlook of the Catholic Church to invite Catholics to be more generous and ambitious in their missionary work in order to make the church more truly universal. ${ }^{11}$

Sykes also criticized the Protestant approach to evangelization, arguing that Protestants concentrated on the mental development of the natives to the prejudice of their practical formation. He claimed that intellectual formation had corrupted the natives and made them more vain and dishonest. An educated black person who lost his or her former simplicity became "insupportable, disobedient, contemptuous of others, even of his superiors, and oftentimes, when trained in the tenets of certain sects, smug and sanctimonious." ${ }^{12}$ An African educated by Protestants, according to Sykes, was also prone to exaggerating his rights and claiming equality with the white man. Sykes's recommendation was that "the native should be taught to use his hands not so much pari passu with his head, but he should be educated by and through his hands [...]. The native should be taught some useful and fairly laborious trade."13

In addition to corrupting the native peoples, Sykes claimed that the work of the Protestant missionaries had actually achieved very little in terms of producing converts; and even when Protestants managed to convert someone, the convert's way of life became worse than it was before his or her conversion. ${ }^{14}$ Those who converted to Protestantism seemed to inherit a "double dose of original sin," losing their African virtues while simultaneously assimilating the vices of the white people. Native vices such as thievery, lying, drunkenness, unchaste behavior, and laziness were only exacerbated by conversion to Protestantism..$^{15}$

In his article, Sykes paints a picture of Rhodesia before the arrival of Jesuit missionaries as a land steeped in the darkness of superstition, with no knowledge of divine teaching, "where the Commandments of God have never been

\footnotetext{
10 Ibid., 15 .

11 See "A Plea for Imperialism: Fr. R. Sykes, S.J. and Missionary Work," Tablet (April 10, 1909): 26.

12 Sykes, "Protestant Missionary Activity," 11.

13 Ibid.

14 One cannot help but remember Jesus's indictment against the Scribes and the Pharisees: "Woe to you, teachers of the law and Pharisees, you hypocrites! You travel over land and sea to win a single convert, and when you have succeeded, you make them twice as much a child of hell as you are" (Matt. 23:15).

15 See Sykes, "Protestant Missionary Activity," 11.
} 
explained to the people; where there is no external sign of the true God, no Church, no Cross, no Blessed Sacrament; which is delivered over to mere naturalism, unabashed, and unaided by any elevating or spiritualizing influences."16 This was the state of the land found by the Jesuits, one "unlit by any ray of Christianity except here and there an infrequent non-Catholic Christian Mission Station just established, but which had not had sufficient time to spread any civilizing or Christianizing influence around."17 In other words, according to Sykes, Protestantism had done little or nothing in terms of evangelization by the time Jesuits arrived in the area. ${ }^{18}$

Sykes expressed similar opinions in his comments on the Kikuyu Conference, an interdenominational meeting held at the Church of Scotland's parish in Kikuyu (in present-day Kenya) in June $1913 .{ }^{19}$ The conference's purported aim was to heal divisions among Protestant denominations working in British East Africa (today's Kenya), Uganda, and Zanzibar, on the one hand, and, on the other, to explore ways of enhancing greater collaboration among Protestant churches in the region. However, Sykes maintained that the conference's real purpose was to create a united front for Protestants against the "solid phalanx of Catholicism and the aggressive cohesion of Mohammedanism." He was convinced that Protestantism was a "disruptive force," a movement that was essentially fissiparous and centrifugal. The attempt to unite various denominations, which he calls "sects," was therefore bound to fail.

It was futile, Sykes argued, to forge unity in accidentals (that is, non-doctrinal matters) while divisions remained in the realm of essentials (doctrine). Sykes's view is partly vindicated by the fact that not all non-Catholic churches were in favor of admitting to the pulpit ministers from other churches or the proposal of giving Communion to members of other denominations should the latter

16 Richard Sykes, “On Creating a Religious Atmosphere," ZMR 5, no.70 (1915): 272-76, here 273 .

17 Ibid.

18 A similar opinion is expressed by an anonymous author of an obituary for Fr. Peter Prestage, S.J. (1842-1907). In his glowing praise of the success of Prestage in evangelizing African peoples, the author writes, "Compared with the noise and fame which have surrounded the careers of such Protestant South African missionaries as the missionaryexplorer, Livingstone, or Moffat, or even of later representatives like Coillard and Steward, the humble and comparatively unknown career of a missioner like Father Prestage seems tame; but it reaches the loftiest heights of human effort in its enduring tenacity and in its heroic quality, if not in its picturesque adventurousness"; see "The Late Father Peter Prestage, S.J.," Tablet (May 4, 1907): 15 .

19 See Richard Sykes, "The Kikuyu from a Missionary's Point of View," ZMR 5, no. 65 (1914): 99-102. 
travel to an area where their ecclesial communities did not exist. Theologian Norman Powell Williams (1883-1943), for instance, argued that there was an essential difference between the Church of England and other denominations, for the former believed in the episcopacy as an essential element of the church's self-understanding. It was, therefore, inconsistent to allow ministers not duly ordained to preach in Anglican churches. ${ }^{20}$ Sykes claimed that the divisions and quarrels among Protestants had obliged civil authorities to parcel out territories to various denominations, compromising the unity of the Christian faith while making it difficult for Catholicism to realize its mission of preaching the Gospel to all peoples.

\section{Alfred Weld, s.J.}

Similar sentiments were aired by Alfred Weld, who succeeded Henri Depelchin, S.J. (1822-1900) as superior of the Zambezi Mission in 1883. Weld is credited with formulating a master plan for the Zambezi Mission. In his contribution to The Tablet of December 31, 1887, he describes the work of Protestants such as the Lutherans, noting that the Bechuana (the local inhabitants) had not yet heard the Gospel of Truth even though the Protestant missionaries had been there for over sixty years: "The neighborhood is alive with Lutheran and other sectarian ministers, who seem to have produced little other influence on these corrupt polygamists than prejudice against the Church."21

With regard to the education of the natives, Weld concurred with Sykes's idea that Africans deserved to be taught useful and laborious trade as opposed to the Protestants' alleged emphasis on mental development. His article indicates how the Jesuits prioritized technical or practical education interspersed with religious education. At Dunbrody (Eastern Cape), for instance, the Jesuits acquired some land formerly belonging to the Trappists, and a religious community was set up on the property where African children were "taught to gain an honest livelihood, and instructed in the elements of education and the precepts of doctrines of the Catholic faith." ${ }^{22}$ Boys were taught agricultural skills, carpentry, shoemaking, and tailoring, among other trades, while girls were trained to wash, sew, knit, and other duties proper to domestic servants.

Before the Jesuits asked the king of the Mangwato for permission to evangelize the natives, Weld had expressed optimism that the African king would be enlightened by the Spirit and welcome the Jesuit missionaries:

\footnotetext{
20 See Norman Powell Williams, The Kikuyu Opinion (London: Longmans, Green and Co., 1915), 1-24.

21 Alfred Weld, s.J., "From the Dark Continent," Tablet (December 31, 1887): 35.

22 Ibid.
} 
It has been said that the Bamanguato tribe are already infected with Protestantism. The chief is a warm supporter of the sect. They are Protestants because they have never known the Catholic faith. Within a few weeks the missioners will present themselves before this man, who has the character of being the justest and most sincere of all the native chiefs in South Africa. If the Holy Spirit will vouchsafe to enlighten his mind, and show him that the Catholic missioners are the bearers of the true doctrine of Jesus Christ, and that what he has hitherto known is only a maimed and disturbed fragment of the truth, the whole tribe may be led to the faith at a stroke. ${ }^{23}$

Thus, for Weld, it was the Jesuits (Catholics) who were the bearers of the true faith. Weld even begrudged the title of "missionary" to the Protestants and simply regarded Livingstone as "the great traveller." ${ }^{24} \mathrm{He}$ also calls Protestant missionaries "ministers of error," sowing seeds of dissension and confusion among the natives. ${ }^{25}$

\section{Appraising the Negative Portrait of Protestant Missionary Work}

There is undoubtedly a grain of truth in what Weld and Sykes say about nineteenth- and twentieth-century Protestant missionary activity in southern Africa, for others beyond the Society of Jesus held similar views. Nonetheless, the failures of the Protestant missionaries would appear to be a common phenomenon extending well beyond the Protestant churches.

One reason for this was the lack of interdenominational cooperation. Most likely inspired by the colonial model, most of the Christian churches in Africa had resorted to the occupation of tracts of land, which became "mini-colonies." The Jesuits, for instance, had acquired land in Chishawasha (Zimbabwe), Chikuni, and Kasisi (both in Zambia), yet the natives who came to live on the land were only able to do so if they met a number of conditions, one of which was that they would send their children to the mission school. ${ }^{26}$

\footnotetext{
23 Weld, Mission of the Zambezi, 54-55.

24 Ibid., 36,38 .

25 Ibid., 35 .

26 See "Chishawasha Mission," Tablet (January 16, 1909): 27; Francis Richartz, "History of Chishawasha," in Early Days of the Jesuit Zambesi Mission, 1880-19oo: Accounts by John Weisskopf and Francis Richartz, ed. Edward Murphy (Harare: Jesuit Province of Zimbabwe-Mozambique, 2015), 77-135, here 91.
} 
There is no evidence that Protestant missionaries were allowed access to the African communities hosted on Catholic settlements. The Jesuits wanted virgin soil in which to plant the seed of the Catholic faith and did not want any "weeds" of adulterated faith to choke the plant of faith. Even in the twentieth century, Catholics were generally opposed to mixing with Protestants. In Northern Rhodesia (today's Zambia), for example, Protestants advocated interdenominational schools, which Catholics found unacceptable, instead preferring "Catholic schools for Catholic children under Catholic management."27

Moreover, regardless of the respective methods they used in their evangelization work, both Catholic and Protestant missionaries were faced with similar challenges in winning and retaining African converts. One of the lessons Weld learned from his few years in Africa was that "the real conversion of the black races, and even of one section of them, is a work of time, not to be achieved by spasmodic or isolated missionary enterprise, but by a continued effort on a carefully conceived plan." ${ }^{28}$ Missionary work, he observed, was compounded by difficulties of language, the caprice and avarice of local chiefs, and inadequate logistical support, among other issues. In the words of John Weisskopf (1848-83), a Jesuit stationed at Pandamatenga (northwest district of Botswana), converting the local people had proven so difficult that success would require God's miraculous intervention. ${ }^{29}$

A further problem affecting the missionaries was related to the native peoples' long-established cultural practices and beliefs. Writing in his diary, the Belgian Jesuit Charles Croonenbergh (1843-99) reported that the missionaries had failed to achieve a great deal among the Ndebele because of their reluctance to abandon the custom of polygamy. ${ }^{30}$ Another obstacle was what he called superstition, consisting in belief in witchcraft. As a result, Croonenbergh was less judgmental when writing about the failure of such missionaries as Moffat and Thomas among the Matabele.

In Croonenbergh's estimation, the Matabele were materialists who had no interest in spiritual goods. While they were eager to receive the missionaries' brandy, calico, and beads, they were not interested in the Gospel. He further describes the Matabele as "a people given over completely to idleness, drowned

27 Brendan Carmody, Conversion and Jesuit Schooling in Zambia (Leiden: Brill, 1992), 81-82.

28 Weld, "From the Dark Continent," 35.

29 John Weisskopf, "Along the Zambezi: 25 June to 19 November 1880," in Murphy, Early Days of the Jesuit Zambesi Mission, 29-72, here 49.

30 See Charles Croonenbergh, "Matabele Customs," in Diaries of the Jesuit Missionaries at Bulawayo, 23-25, here 23 . 
in laziness and in all its allied disorders, having practically no conception of divinity, no notion of justice or injustice, and all of whose institutions and customs are diametrically opposed to the teachings of the Gospel."31 Francis Berghegge, s.J. (1849-1916) had a similar view of the people of Mambova, who, despite their affability, seemed to find greatest happiness in food and beer. ${ }^{32}$

Thus it is clear that the lack of African converts could not be blamed squarely on Protestant ineptitude. The problem was not necessarily in the approach of the Protestant missionaries; the difficulty was that the worldview of the African peoples did not tally with the Christian message as preached by European missionaries, whether Catholic or Protestant. The Ndebele, for instance, had their own repertoire of religious rituals that helped them to address the day-to-day challenges facing the community. ${ }^{33}$ Though Croonenbergh doubted the "religiosity" of these ceremonies, the fact remains that the local peoples were convinced that their religion did not need to be replaced with another. Indeed, some Africans regarded the missionaries as a people without a religion, for the Europeans did not seem to hold religious services. ${ }^{34}$

Having understood how secondary, if irrelevant, the Gospel appeared to be for the natives, the Jesuits devoted their early years in Matabeleland responding to the material and practical needs of the local people. Croonenbergh himself spent much of his time providing medical services to the people. As a result, despite spending an entire year in Matabeleland, Jesuits could only report the baptism of a leper ostracized by the community. ${ }^{35}$

The Ignatian principle of entering through the people's door in order to exit through one's own was of critical importance in the Jesuits' interactions with the African peoples. Francis Richartz, S.J. (1854-1928) concedes that, at Chishawasha, evangelization

was a work that required a good deal of patience because there were hardly any signs of success or interest in our lessons. While a person longs for happiness he finds it in food and drink. It will be a long time before he will appreciate the homily and this is the cross of the missionary.

31 Charles Croonenbergh, "A Letter from Father Croonenbergh," in Diaries of the Jesuit Missionaries at Bulawayo, 30-33, here 31 .

32 See Fien Berghegge, "Account of a Journey in Central Africa," Rhodesiana 3 (1958): 1-13, here 5 .

33 See Charles Croonenbergh, "The King Makes Rain," in Diaries of the Jesuit Missionaries at Bulawayo, 61-65, here 61-63.

34 See Berghegge, "Account of a Journey in Central Africa," 6.

35 See Charles Croonenbergh, "Visit of the Queens," in Diaries of the Jesuit Missionaries at Bulawayo, 59, 62 . 
He has to use all means and tricks patiently to enter in through the door of the people, so as to leave by his own door. The missionary must be aware from the very beginning that it will not be a quick victory. ${ }^{36}$

Catholics, like Protestants, also experienced the challenge of keeping converts true to the faith. This difficulty was acknowledged by a Jesuit missionary working in the Zambezi Mission. After sharing the good news that the number of baptized Africans had reached 1,734, the Jesuit admitted that the more challenging task was to "keep what we have won, to preserve the converted native in the practice of Catholicity. This is indeed the great problem of all missionaries in Africa. It is almost more difficult to keep the native true to the faith than to win him to the faith." ${ }^{37}$ One of the factors contributing to the loss of converts was the high mobility rate among Africans. Their departure from one area to another in search of work often entailed their departure from the faith they had embraced. The introduction of Christian villages was, in fact, meant to mitigate the relapse of African converts into "heathenism."38 To criticize Protestant missionary work on the basis of its products is thus to be blind to dynamics beyond the control of any missionary. ${ }^{39}$

Croonenbergh was also aware that the African situation was not unique in the history of evangelization. It had been equally difficult to evangelize the Saxons of Germania and the "cannibals" of Oceania. With a sober grasp of what some scholars would call "anthropological constants," he affirms that

humanity is everywhere the same, and, where Christianity does not exist, the same aberrations exist in all parts of the world. It would be a most interesting study to make a research into the analogies which exist

$36 \quad$ Richartz, "History of Chishawasha," 93.

37 "Progress in the Mission during 1913," ZMR 5, no. 64 (1914): 58-6o, here 59.

38 Dachs and Rea, Catholic Church and Zimbabwe, 6.

39 In fact, elsewhere, Jesuits have similarly been unfairly judged by Protestants. The anonymous author (signed simply as "K") of the article "The Pope and Romish Missions" gratuitously accuses Jesuits of planting the wrong faith in Asia and in Latin America, a faith that conformed to the traditions of the local people and revolved around rituals and devotions (sensuous religion), rather than a true appreciation of the Gospel. In their work of evangelization, the author continues, Jesuits accumulated and made use of immense earthly goods, all the while professing evangelical poverty. See "The Pope and Romish Missions," Church Missionary Intelligencer and Record (October 1886): 721-35; "On the Character of Jesuit Missionary Teaching," Church Missionary Intelligencer and Record (July 1886): 529-45. These accusations, like the ones made by Jesuits against Protestants, would lose their force when evaluated in a broader context. 
between the superstitions of our Matabele and those of the ancient pagan people of Italy, of Greece, of Syria and of Egypt. ${ }^{40}$

As we saw above, Sykes expressed disapproval of the Protestant approach to the education of the natives, arguing that Protestants wrongly focused on mental education instead of empowering the Africans with practical (manual) skills. But time would be a better judge. Indeed, by 1914, the more informed view was in favor of the integral education of the Africans. The editorial for the sixty-third issue of the $Z M R$ attests to the shift in public opinion:

It is true that we still meet people in this land who maintain that it is sheer waste of time and energy to give schooling to the blacks, and that the "raw," i.e., the uncivilized and uneducated, native is in every way superior to the product of the mission schools. But persons who say this speak without reflection and without any acquaintance with the subject. They have absolutely no knowledge of the good which is effected in the souls and minds of the natives by the teaching of the missionaries, and their deep-rooted hostility to the religious and literary training of the blacks is in most cases based on a few instances of hypocrisy, sloth or vice on the part of educated natives, which have come to their notice or about which they have heard. They quite ignore the fact that the almost unanimous verdict of those who have thoroughly and impartially investigated the subject is against them. ${ }^{41}$

The editorial speaks not only of "religious training" but also of "literary training." The self-definition in the editorial is not "Catholic" as opposed to "Protestant," but rather the common tag of "Christian missionaries." Protestants and Catholics found themselves united in a common cause, and their common quest was to persuade the colonial government to leave the education of the natives to religious bodies, though the government would have to provide some requisite funding. The missionaries wanted to have exclusive rights to the intellectual, religious, moral, and technical formation of the Africans.

It would appear that Sykes's opinion was partly informed by the view that the vocation of Africans was limited to the execution of menial tasks, often at the service of white people. In fact, the importance of an educated African was already clear in the early twentieth century when the colonial government

40 Charles Croonenbergh, "Justice and Religion under Lobengula," in Diaries of the Jesuit Missionaries at Bulawayo, 47-50, here 48. 
in Northern Rhodesia would sometimes hire skilled Africans from Nyasaland (who had received an education in Protestant schools) to serve as clerks, among other jobs. It is also reported that Africans in Northern Rhodesia who had the financial resources to do so would send their children to boarding schools in Nyasaland and Southern Rhodesia. Later, the Free Church of Scotland working among the Bemba adopted the education policy of Protestant churches in Nyasaland, just as the Primitive Methodists serving among the Tonga "believed that Africans had the potential to develop intelligence equal to Europeans." ${ }^{22}$ The first two teachers' training centers in Northern Rhodesia were set up by the Primitive Methodists at Kafue and the Paris Evangelical Mission at Sefula. ${ }^{43}$ The contribution of these centers to the education of the local population cannot be overemphasized.

Sykes opposed the mental formation of Africans, instead calling for the development of their technical skills. However, as more and more Africans acquired technical skills, some European artisans expressed their opposition to the industrial training of the natives, because European artisans, being more expensive than Africans, risked losing job opportunities. Consequently, some Europeans advocated limited industrial training of Africans so that they would remain assistants of white artisans. The Jesuits apparently supported the position of the colonial government, namely that individual Africans should be given as much technical training as their capacity could muster rather than setting an upper limit to the technical education they could receive. In the words of an editorial in the $Z M R$ :

Why, for instance, should an intelligent native boy, who shows an aptitude for bricklaying, stonemasonry or carpentry, be debarred from receiving instruction in these trades because he may, if taught them, become a competitor of the European workman? [...]. How much the whole country would have benefited; how many buildings at present non-existent would have been erected if cheap skilled native labor had been available! ${ }^{44}$

The divisions on this issue were ultimately about the interests of those involved in this debate and the role they envisaged for native Africans in wider society. Thus, whereas some missionaries believed it was preferable for native

\footnotetext{
42 Miles Larmer, "History of Zambia: 1902-1924," in History of Jesuits in Zambia, 115-41, here 131.

43 Ibid., 130.

44 “Editorial," ZMR 5, no. 66 (1914): 117-19, here 118.
} 
Africans to receive technical training rather than mental formation because they viewed Africans as servants of the European settlers, white artisans opposed a high-level of technical training for the natives because they stood to lose jobs to Africans regarded as cheaper labor. Prospective employers, on the other hand, held to the view that native African artisans should receive the highest level of technical training because they would be able to save costs by hiring trained Africans. The question was not simply about mental or technical formation, in short, but what and whose interest such an education fostered or jeopardized.

\section{The Brighter Side of Jesuit-Protestant Cooperation}

In contrast to the views outlined above, a number of other reports written by Jesuits paint a more positive picture of the Protestant missionaries deployed in southern Africa and beyond. Though these reports do not necessarily speak about the successes of the Protestant missionaries, they do show that Protestants were not sworn enemies of Catholicism; rather, they were willing to share life (commune) with Catholic missionaries. These positive accounts emanate from contexts where Jesuits shared life with Protestants. General Congregation 34 of the Jesuits would later call this the "dialogue of life, where people strive to live in an open and neighborly spirit, sharing their joys and sorrows, their human problems and preoccupations." 45

\section{Jesuits in Praise of Protestant Hospitality}

As we have seen, the Jesuit return to Africa in the nineteenth century was preceded by the arrival of various Protestant missionaries who established themselves in different parts of southern Africa. A number of Jesuits gratefully recalled how Protestants accorded them hospitality as the new arrivals struggled to find their feet on the ground. In his letter to the editor of The Tablet, Weld recalls how, at Kimberley, "Protestants vied with Catholics in rendering them [the Jesuits] service." 46

Similarly, the Jesuits at Gubulawayo (present-day Zimbabwe) waxed lyrical about the kindness they received from the Protestants there. Without any

45 General Congregation 34, decree 5, no. 4: "Our Mission and Interreligious Dialogue," in Jesuit Life \& Mission Today: The Decrees \& Accompanying Documents of 31st-35th General Congregations of the Society of Jesus, ed. John W. Padberg (St. Louis: Institute of Jesuit Sources, 2009), 547-56 here 548 .

46 Alfred Weld, "Mission of the Zambesi," Tablet (February 14, 1880): 22. 
knowledge of the locallanguage, the Jesuits relied on the help of their Protestant counterparts to conduct diplomatic transactions with the king and ordinary intercourse with the local population. In one of his diary entries, Depelchin writes, "We have had a long talk with the Protestant ministers: these gentlemen have treated us with the greatest courtesy." 47 Croonenbergh makes a similar point and names the Protestants in question: "Mr. Fairbairn and Mr. Martin, English Protestant gentlemen who live here [...] have done us a great service. [...] I am enjoying the kind hospitality of Mr. Martin who treats me like a son, indeed like a spoilt child." 48 When Croonenbergh was ill, it was Martin who looked after him. Understandably, he calls Martin "our benefactor."49

As they shared life together, the prejudices between the Jesuits and the Protestants began to dissipate. In Croonenbergh's words: "With the Protestant ministers, too, despite the difference of our religious beliefs, we have the most cordial relationships. Meeting as we do, in close intimacy, many prejudices vanish, many misapprehensions disappear. Recently, all the Protestant Missionaries, five in number, met at our house."50

\section{Collaboration}

Jesuits acknowledged the Protestants' spirit of collaboration. Because of their proficiency in the local language and the influence they exercised over Lobengula, king of the Ndebele (c.1840-94, r.1870-94), Protestant ministers helped the Jesuits at Gubulawayo to win the king's acceptance and friendship. Martin often accompanied the Jesuits to the king's court and spoke in favor of the Jesuits. Charles Daniel Helm (1844-1915), an LMs missionary at Hope Fountain, also accompanied Croonenbergh to the king's court and introduced the Jesuit as a recently arrived $m$ fundisi (teacher) of Gubulawayo. Despite religious differences, Helm did not begrudge sharing the title mfundisi with the Jesuit. He was clearly a tolerant man, for, when the Jesuit explained to Lobengula why Catholic missionaries did not have wives, Helm, "a most excellent paterfamilias, not quite knowing how to keep himself in countenance, cloaked himself in a great cloud of smoke, and pulled upon his pipe with exceeding vigor."51

47 Henri Depelchin, s.J., "King Lobengula," in Diaries of the Jesuit Missionaries at Bulawayo, 16-18, here 17.

48 Charles Croonenbergh, "Father Croonenbergh's Account," in Diaries of the Jesuit Missionaries at Bulawayo, 21-23, here 22.

49 See Charles Croonenbergh, "Christian Worship," in Diaries of the Jesuit Missionaries at Bulawayo, 26-30, here 26.

$50 \quad$ Charles Croonenbergh, "Other Missionaries and Traders," in Diaries of the Jesuit Missionaries at Bulawayo, 39-42, here 40.

$51 \quad$ Ibid., 54 . 
Evidently, he did not want to antagonize the Catholic missionary by contesting the foundations of priestly celibacy.

Another case that reveals the willingness of Protestants to collaborate with Catholics, which took place at Driefontein (in Mpumalanga Province, South Africa), on Tuesday, April 13, 1915, involved a man who was dying at a mine hospital. A Protestant missionary arrived at the hospital by train and saw the patient, who asked for a Catholic priest. The Protestant set off at once, though it was already dark, to look for a priest, covering more than twenty miles on foot before arriving at the Catholic mission at 2:30 in the morning; a Catholic priest was then sent immediately to the hospital, arriving before the patient's death. The patient received the last sacraments and passed away a few hours later. The writer of the account, himself a Catholic, enthusiastically describes the non-Catholic missionary as an "angel of the Lord." 52

Another platform for collaboration between Jesuits and Protestants was the General Missionary Conference, which started in June 1914. The idea of setting up the conference was mooted in 1913 while Christians from various denominations were working together in translating the Bible. The conference boasted the membership of four Catholic orders, namely the White Fathers, the Jesuits, the Franciscans, and the Capuchin Fathers, and in the reviews and evaluations of the various participants, explicit mention is made of Jesuit participation. Reverend Sydney Douglas Gray (1883-1964), of the Wesleyan Methodists, for instance, mentions John Spendel (1880-1945) and Joseph Moreau (1864-1949), both Jesuits, who made an impression on him for their inspiring lives. Gray even reported that the devotional paper Spendel read at the conference "might have been written by a good Methodist." ${ }^{33}$ The conference was an occasion for various missionary groups to overcome prejudices and to appreciate their common humanity and Christian faith. It was remarked, for example, that these missionaries, Protestant and Catholic alike, "all met on a common level, comparing notes with each other, chatting over meals or round the camp fires, and becoming friends. Some were surprised to discover so much goodness in those they had hitherto considered bitter enemies." 54

\section{Recognition of Protestant Missionary Ability}

Early Jesuit missionaries in southern Africa knew how to give credit where it was due. And this was the case with their interaction with Protestant missionaries, some of whom exuded exceptional talents in the spheres of language

$5^{2}$ "Notes from the Different Stations," ZMR 5, no. 69 (1915): 226-33, here 229-30.

53 Cited in Peter Bolink, Towards Church Union in Zambia (Franeker: T. Wever, 1967), 133.

54 Ibid. 
and relations with local communities. Livingstone, for instance, is universally said to have won the friendship and loyalty of African peoples, both kings and subjects. When he died, his porters not only made an inventory of all the things that belonged to the traveler but also traveled a thousand miles to deliver the body (together with all his possessions) to the Englishmen who came to meet them at Unyanyembe. Contemplating Livingstone's exploits, Weld writes that "it is impossible to read these things without a deep pang of regret that Catholic missioners had not the opportunity of gaining that influence over these people which was accorded so willingly to a passing traveller. Livingstone is full of praise of the intelligence and fidelity of this people." 55

Weld also gives credit to Moffat for "the really great work of translating the Bible into the Sichuana,"56 the local language of the area. Similarly, Berghegge describes François Coillard (1834-1904), a French Protestant missionary, as a "complete master of the [local] language." Coillard taught the Africans psalms, which the natives sang, albeit imperfectly, at beer parties long after Coillard had left. ${ }^{57}$

\section{Conclusion}

It is a truism that history is often written from a particular standpoint, one that is not insulated from the thinking of the time and the exigencies of sectarian interest. Ideologies and interests partly determine the selection of data. The Second Vatican Council (1962-65), with its new vision of the relationship between the Catholic Church and other churches, marks an important watershed in the appreciation of the history of the interaction between Catholic and Protestant missionaries. The premium the council placed on ecumenism and interreligious dialogue is an invitation to re-read the history of missionary work in Africa - and the world over-in order to scout for fragments of mutual esteem and collaboration between Catholics and Protestants. Such insights would serve as precedents and lessons for strengthening the collaboration among different churches. This essay has used accounts from the nineteenth and twentieth centuries in order to paint a more accurate picture of the Jesuit estimation of the Protestant contribution to the evangelization of the peoples of southern Africa. Generally, Jesuits who interacted with Protestants

\footnotetext{
55 Weld, Mission of the Zambezi, 17, 38-39.

56 Ibid., 24 .

57 See Berghegge, "Account of a Journey in Central Africa," 7.
} 
more closely (dialogue of life) had many more good things to say about nonCatholic missionaries than has often been assumed.

\section{Bibliography}

Berghegge, Fien. "Account of a Journey in Central Africa." Rhodesiana 3 (1958): 1-13.

Bolink, Peter. Towards Church Union in Zambia. Franeker: T. Wever, 1967.

Burrett, Rob S. "The Zambezi Mission and the Residences of Good Hope and Immaculate Heart of Mary, Old Tati." Botswana Notes and Records 32 (2000): 25-38.

Carmody, Brendan. Conversion and Jesuit Schooling in Zambia. Leiden, New York, and Cologne: Brill, 1992.

Clinton, Iris. Hope Fountain Story. Bulawayo: Mambo Press, 1969.

Dachs, Anthony J., and William F. Rea. The Catholic Church and Zimbabwe. Gwelo: Mambo Press, 1979.

Diaries of the Jesuit Missionaries at Bulawayo 1879-1881. Rhodesiana Society 4. Bulawayo: Mardon Printers, 1974.

K. "On the Character of Jesuit Missionary Teaching." Church Missionary Intelligencer and Record (July 1886): 529-45.

K. "The Pope and Romish Missions." Church Missionary Intelligencer and Record (October 1886): $721-35$.

Larmer, Miles. "History of Zambia: 1902-1924." In A History of Jesuits in Zambia: A Mission Becomes a Province, edited by Edward P. Murphy, 115-41. Nairobi: Paulines Publications Africa, 2003.

Murphy, Edward, ed. Early Days of the Jesuit Zambesi Mission, 1880-19oo: Accounts by John Weisskopf and Francis Richartz. Harare: Jesuit Province of ZimbabweMozambique, 2015.

Padberg, John W., ed. Jesuit Life \& Mission Today: The Decrees \& Accompanying Documents of 3ist-35th General Congregations of the Society of Jesus. St. Louis: Institute of Jesuit Sources, 2009.

Rea, William Francis. "Rhodesian Pioneer." Rhodesiana 5 (1960): 54-59.

Sykes, Richard. "On Creating a Religious Atmosphere." ZMR 5, no. 70 (1915): 272-76.

Sykes, Richard. "Kikuyu from a Missionary's Point of View." ZMR 5, no. 65 (1914): 99-102.

Sykes, Richard. "Protestant Missionary Activity in South and Central Africa," ZMR 1, no. 1 (1898):11-15.

Sykes, Richard. "The Missioner's Debt." ZMR 5, no. 63 (1914):15-19.

Weld, Alfred. "From the Dark Continent." Tablet (December 31, 1887): 35 .

Weld, Alfred. Mission of the Zambezi. London: Burns and Oates, 1879.

Williams, Norman Powell. The Kikuyu Opinion. London: Longmans, Green and Co., 1915 . 
Robert Aleksander Maryks and Festo Mkenda, S.J. - 978-90-04-34715-1 Downloaded from Brill.come4/26/2023 02:06:52PM via free access 


\section{PART 4}

\section{Encounters in Madagascar, Congo, and Fernando Poo}


Robert Aleksander Maryks and Festo Mkenda, S.J. - 978-90-04-34715-1 Downloaded from Brill.come4/26/2023 02:06:52PM via free access 


\title{
Jesuits and Protestants in Nineteenth-century Madagascar
}

\author{
Jocelyn Rabeson, s.J.
}

This chapter examines the encounter between Jesuits and Protestant missionaries in Madagascar in the nineteenth century. This encounter unfolded over four distinct periods: (1) the establishment of Christianity between 1818 and 1836; (2) the persecution of Christians between 1836 and 1861; (3) the return of religious liberty between 1861 and 1896 ; and (4) Christianity during the early colonial period between 1896 and 1900. Each of these different periods in turn resulted from the decision of the Merina kingdom's monarchs ${ }^{1}$ to embrace or reject Christianity, which affected and shaped the relationship between Jesuit and Protestant missionaries and their respective activities. The chapter follows the same chronology of events by narrating the encounter between Catholic missionaries, namely the Jesuits, and those of the Protestant Church, namely the London Missionary Society (LMS), in the central area of Madagascar, the Merina kingdom where all missionary activities began and from where they spread throughout the island. ${ }^{2}$

1 These monarchs are: Radama I (r.1810-28), Ranavalona I (r.1828-61), Radama II (r.1861-63), Rasoherina (r.1863-68), Ranavalona II (r.1868-83), and Ranavalona III (r.1883-96).

2 It is worth noting that the country's first contact with Christianity goes as far back as the sixteenth and seventeenth centuries. In the nineteenth century, the desire of all missionaries was to enter the inland where some progress was already taking place in various aspects of society. The main source of this chapter is Adrien Boudou's (1876-1945) twovolume book on the history of the Jesuits in the nineteenth-century Madagascar, which is supplemented by the history of Protestant missions as narrated by some Protestant missionaries themselves. Boudou's work is based on the books, diaries, and correspondence of the early Jesuit missionaries as well as the writings of the early Protestant missionaries. Taken together, the two volumes consequently present a comprehensive view of the Jesuit mission in the nineteenth century. The Protestant missionaries' writings, on the other hand, cover the Protestant missions throughout the nineteenth century. See Adrien Boudou, Les Jésuites à Madagascar au XIX siècle, 2 vols. (Paris: Gabriel Beauchesne et Fils, 1940). 


\section{Establishment of Christianity and Persecution of Christians}

In 1817, the British government, through Sir Robert Farquhar (1776-1830), governor of Mauritius, and Radama I (1793-1828, r.1810-28), then king of Madagascar, entered into an agreement whereby the king would abolish the slave trade in return for the governor's military support and other advantages. This agreement was actually never implemented and by 1820 it had been completely forgotten. However, the governor was still anxious to renew it. It was in the context of new efforts to renew the 1817 agreement that the LMS came to the country.

The first LMS missionaries, Thomas Bevan (c.1796-1819) and David Jones (1796-1841), ${ }^{3}$ together with their respective families, entered the east coast of Madagascar in 1818 for a short exploration. Unfortunately, Jones's wife and daughter died of fever shortly after entering the island, and Bevan and his family succumbed to the same fate in $1819 .{ }^{4}$ Thus, after a short vacation to Mauritius to recover his health, Jones ultimately traveled to the central area of Madagascar with James Hastie (1786-1826), the governor's agent who was appointed to Antananarivo in view of re-establishing the treaty. Radama I welcomed them on September 4, 1820, renewed the treaty and, upon learning of the object of Jones's visit, made a request in a letter to the LMs Board of Directors: "I request you to send me, if convenient, as many missionaries as you may deem proper, together with their families if they desire it; provided you send skillful artisans to make my people workmen and good Christians." Jones began his mission by building a school, ${ }^{6}$ and he was soon followed by other pastors and artists, including David Griffiths (1792-1863), who became his close collaborator.

During this period, the missionaries were under the king's protection and they managed to make a great deal of progress. There were already three Christian schools in Madagascar by 1823 - the principal aim of which was to

3 Thomas Bevan and David Jones's mission to Madagascar was triggered by their mentor, one Dr. Phillips, in the seminary. Dr. Phillips himself once asked his students "who will go as a missionary to Madagascar?" Jones and Bevan at once responded, each for himself, "I will go." See Richard Lovett, The History of the London Missionary Society, 1795-1895 (London: Oxford University Press, 1899), 674.

4 See ibid., 675 .

5 Ibid., 676. The letter is dated October 29, 1820. It is to be noted that part of the agreement was the sending of Malagasy youth to Mauritius and Britain for instruction. See also William Ellis, Three Visits to Madagascar during the Years 1853-1854-1856 (London: John Murray, 1858), 1-3.

6 School would play an important role in the mission of the LMS. According to the second report of the Madagascar Missionary School Society of 1828 , by the same year "there were in the capital and surrounding country thirty-seven schools with forty-four teachers and 2309 scholars"; see Lovett, History of LMS, 683. 
train the natives as missionaries of their own country—and on February 22 in the following year, Radama granted the missionaries permission to preach in the local Malagasy language. Jones would preach the first sermon two days later. ${ }^{7}$ On the following day, a "communion service was administered for the first time in Malagasy." ${ }^{8}$ Work on translating the Bible into Malagasy, meanwhile, began in 1820, with the New Testament translation being completed by 1825 ; the full translation was complete, printed, and distributed in 1835 .

All this was to change, however, following the death of Radama I and the accession of Ranavalona I in 1828 (1778-1861, r.1828-61). Although the new queen initially showed some tolerance toward the proselytism of the LMS and even allowed baptism and the celebration of the last supper, ${ }^{9}$ she eventually came to realize that adherence to Christianity posed a danger to her monarchy. As a result, at the end of 1831 , when the progress of Christianity was beginning to alarm the authorities, ${ }^{10}$ the queen became increasingly hostile to the missionaries doing anything other than artisanal and educational work. ${ }^{11}$ There were three main reasons for this anxiety, each of which was connected to the other. The first was that the queen saw the Christian religion as an external ideology that contradicted the fundamental values and beliefs of the Malagasy people. The second was that Christian education had begun to plant the seeds of democratization ${ }^{12}$ in the minds of the natives - including leaders and military officers, as well as simple citizens-and this posed a threat to the monarchical ideology that the queen and the oligarchy wanted to protect and consolidate. Third, as a result of the first two factors, converting to Christianity not only became a form of political and religious protest but also an acceptance of foreign ancestors instead of faithfulness to native ancestors venerated by the Malagasy people and from whom the queen's sacred authority flowed..$^{13}$ This raised the possibility that the queen could lose her "prestige sacré,"14 which had previously been respected and venerated by the people.

$7 \quad$ Ibid., 677 .

8 Ibid., 678.

9 See ibid, 689 .

10 Micheline Rasoamiaramanana, "Le rejet du christianisme au sein du royaume de Madagascar (1835-1861)," in Madagascar et le Christianisme, ed. Bruno Hübsch (Antananarivo: Editions Ambozontany, 1993), 217-40, here 222.

11 Lovett, History of LMS, 688.

12 Adherence to Christianity required a rupture from the past and from the community.

13 Rasoamiaramanana, "Le rejet du christianisme au sein du royaume de Madagascar," 222-24.

14 A Malagasy monarch was considered a living divinity. His or her legitimacy stemmed from his or her enthronement to the vato masina (sacred stone) and the Hasina (offerings) from the people. 
Consequently, while acknowledging the good things done, and allowing the missionaries to follow their customs, the queen urged the missionaries to abide by Malagasy laws and prohibited the Malagasy people from practicing the Christian religion..$^{15}$ On March 1, 1835 , the queen gave an official kabary (proclamation or speech) in which she announced that native Christians would face the death penalty for practicing the Christian faith.

This was the start of the persecution of Christians in Madagascar. Christians endured torture and executions for the next twenty-five years: many of them were tied, wrapped in tsihy (a traditional rug) and thrown down a hill, while others were beheaded. Some missionaries left the capital at the center of the island and moved to the coast, others stayed in Mauritius, and others simply returned to Britain. Some would go back to the coastal area and attempt to enter the capital again. ${ }^{16}$ To this day, the Malagasy people in general, and the Protestant church in particular, celebrate the martyrdom of Rasalama (c.1810-37), a Protestant woman, who was executed by the sword on August 14, 1837 .

While the persecution was underway in central Madagascar, Catholic missionaries began to engage in missionary work in the north and east of the country. In 1832, Fr. Gabriel Henri Jérôme de Solages (1786-1832), who had been appointed apostolic prefect in charge of Bourbon, Madagascar, and the Oceania and Pacific islands since $1829,{ }^{17}$ disembarked in Toamasina on the east coast with the aim of meeting the queen to suggest building a high school for girls. However, after receiving advice from some Protestant pastors, ${ }^{18}$ the queen rejected Solages's request.

When Solages died on December 8, $1832,{ }^{19}$ he was replaced by Fr. Pierre Dalmond (1800-47) —not a Jesuit—who had already visited the small

15 Letter addressed to the missionaries on February 26, 1835, a translation of which can be found in Lovett, History of LMS, 694-95.

16 It is to be noted that, in his two-volume history of the Jesuits, Boudou critically recounts the story of the mission of the LMS as well as the persecution of Protestants based on the publications of Protestant missionaries such as James Sibree (1836-1929). Boudou sees the combination of politics and religion in the entrance of LMS into the island. His description, although accurate, seems to show the tension between the British and the French, which also meant the Protestants and the Catholics respectively. See Boudou, Les jésuites à Madagascar, 1:229-34.

17 See Boudou, Les jésuites à Madagascar, 1:9-10.

18 The letter was written by David Griffiths, David Johns (1794-1848), and Joseph John Freeman (1794-1851) of the LMS; see ibid., 27-28. Ibid., $18-33$. 
island of Sainte Marie three times. ${ }^{20}$ Dalmond was named apostolic prefect of Madagascar in 1842 and immediately decided to go to Europe to look for help, to which request the Society of Jesus responded positively, and he returned to Madagascar with six Jesuits. ${ }^{21}$ These Jesuits worked in the north of the country in an area known as Nosy Be. One of the many activities in which they were involved was the instruction of young Malagasy children in La Réunion, particularly at the Jesuit residence called La Ressource. ${ }^{22}$ One of these children was Basilide Rahidy (1839-83), son of the prince of the Betsimisaraka ethnic group known as Linta. Rahidy became the first Malagasy to be ordained Jesuit priest in $1874 \cdot{ }^{23}$

When Dalmond died in 1847 , the Catholic mission still remained in the islands where small Christian communities had started to develop. ${ }^{24}$ It was only in 1855 that a Jesuit priest, Marc Finaz (1815-80), came to Antananarivo at the center of Madagascar. Due to the persecution underway, he changed his name to Hervier, which was his mother's name, and introduced himself as the secretary to the French trader Joseph Lambert (1824-73), a friend of the queen. Finaz managed to celebrate Mass on July 8, 1855 before the queen's son and likely successor to the throne. ${ }^{25}$ Through the prince, he secured permission to stay in the country, and two other Jesuit priests, Louis Jouen (1805-72) and Joseph Webber (1819-64), would later come to join him. The two entered Antananarivo with changed names and introduced themselves as a medical assistant and pharmacist respectively. With such disguises, they were allowed into the city despite the advice of Reverend William Ellis (1794-1872), the director of the LMS at the time, who had urged the prince to prevent the French from

20 The trips took place in July 1837 , June 1838 , and April 1839. It is believed that he baptized over a thousand natives during these trips.

21 The six Jesuits were Fathers Pierre Cotain (1795-1871), Ambroise Neyraguet (1799-1861), Joseph Bobiller (1813-70), Romain Dénieu (1800-70), and Brothers Charles Remacle and Félicien Jouffre. See Boudou, Les jésuites à Madagascar, 1:97.

22 La Ressource, Dalmond's project, was supposed to serve as a place both of rest for future missionaries to Madagascar and of instruction of young Malagasy brought by the French government for training in fields such as agriculture, catechism, school administration, and so on. Initially, the project failed, but it was revived by later missionaries. See the letter of Fr. Dalmond to his parents on January 18, 1845 in Boudou, Les jésuites à Madagascar, 1:98-99.

23 Bruno Hübsch, "Difficultés des Missions Catholiques à Madagascar (1820-1861)," in Hübsch, Madagascar et le Christianisme, 241-56, here 242-53.

24 Fr. Louis Jouen and Fr. Marc Finaz, who would be the first Jesuit missionaries to enter the interior of the island or the capital of Madagascar, were appointed apostolic prefects of Madagascar and the small islands respectively in $185^{0}$.

Boudou, Les jésuites à Madagascar, 1:277. 
gaining influence in the country. Ellis himself had visited Toamasina twice (in 1853 and in 1854), but his request to reach Antananarivo had been denied on both occasions. When his request was finally granted, he decided to go back to Madagascar in 1856 where he met Lord Clarendon (1800-70), then foreign minister, who told him about his meeting with Lambert and about the letter of Prince Rakoto (who would later become King Radama II) to Napoleon III $(1808-73)$. The main goal of Ellis's visit to Antananarivo was to fight against French (meaning "Jesuit" and "Catholic") influence. ${ }^{26}$ Finaz and Webber remained in the country for a few months, during which time they witnessed the unsuccessful attempt to overthrow the queen on June 20, 1857. After being accused of helping to plot the coup, the two men were forced to leave the country.

\section{The Return of Religious Freedom}

Ranavalona I's son, Radama II, took over the throne after her death. Shortly after taking power, Radama wrote to his European friends in the coastal area and to others in Europe, ${ }^{27}$ declaring religious freedom in Madagascar. From then on, Protestants and Catholics were free to practice their faith and seek converts, and they hurried to the capital to take advantage of the newly proclaimed freedom. Among the Jesuits who came the same year were Webber (September 23, 1861) and Jouen (October 12, 1861); they were later followed by many more Catholic missionaries, including the Sisters of St. Joseph of Cluny. In a meeting with Webber the day after his arrival, the king expressed his openness to Protestants and Catholics as well as his inclination toward Catholicism. Webber summarized the king's remarks as follows: "Come, preach, establish yourselves openly and as soon as possible; be the first to establish yourselves, and you will have a lot of influence." ${ }^{28}$

However, the Jesuits discovered that, apart from cultural challenges, the most difficult obstacle to the evangelization of the Malagasy people was the "Protestant heresy" that had reached the center of the country before their own arrival. They acknowledged that, until the return of religious freedom, the

\footnotetext{
26 See ibid., 1:285-89.

27 Boudou related that Radama II wrote one letter to Queen Victoria (r.1837-1901), four to the governor of Mauritius, and three to Rev. Le Brun, head of the Protestant missionaries in Port Louis; he also wrote to the governor of the Island of Reunion, Baron Darricau, and to Laborde as well; see Boudou, Les jésuites à Madagascar, 1:371. 
Malagasy people had only known the form of Christianity proclaimed by the LMS. Now that freedom was back, the missionaries wanted to resume the mission from where they had left it twenty-five years ago and revive their work. ${ }^{29}$

The news of Ranavalona I's death and her son's accession to the throne reached Ellis as well as the LMS Board of Directors. Meeting on October 14, 1861, the board appointed a "sub-committee to confer with Mr. Ellis upon the whole case." At the same time, they also called on the British government to "use their utmost influence to prevent the establishment of a French protectorate in that island, should such a project be entertained." ${ }^{30}$ Ellis reached Antananarivo in June 1862 . He was later followed by other missionaries with different talents, including medical doctors, printers, and schoolmasters. In addition to the work of evangelization, one of their main tasks was the construction of memorial churches on the sites where the native Christians had lost their lives during the persecution. The Catholic missionaries who were already at work were seen as "agents pursuing the invariable policy of Rome. They denounced Protestantism, they attempted to secure the direction of affairs, and they showed no scruples in the means they adopted to secure their ends." ${ }^{31}$

The first point of friction between the Protestant and Catholic missionaries took place over schools. The Jesuits wanted to recruit and send children to La Ressource, but they had been prevented from doing so. The reason for this was that the elders were still under the influence of the British (Protestants). Fr. Boy claimed that "they [the Protestants] do everything possible to morally prevent people from coming to us, for fear that they might become Catholics." ${ }^{2}$ Indeed, former Protestant recruits who wanted to join the Catholic Church were intimidated or accused of being paid by the Jesuits. Protestant pupils made fun of the Catholics by calling them les priants d'une seule case (those who pray in one single room) whereas they, lecteurs de la bible (readers of the Bible), had multiple houses in which to meet. ${ }^{33}$ Despite such antagonism, however, in the early stages of their mission, there were also examples of cooperation, with Jesuits and other Catholic Christians being treated at a hospital that was run by Protestants, for example.

The Jesuits lamented the French abstention from Madagascar, as a result of which the Protestants were reaping the fruits. At the same time, they knew that they had the king's sympathy and support. The main proof of this was

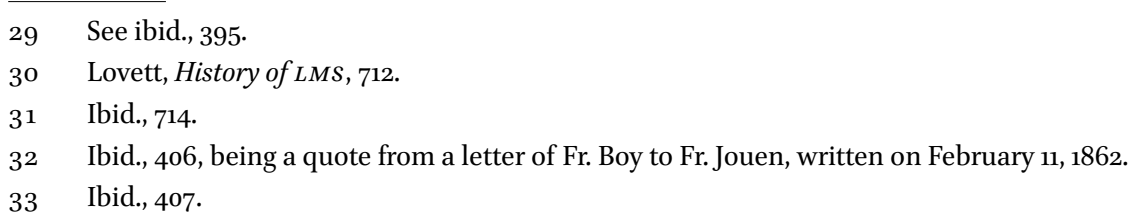


the private celebration of the Eucharist with the king and his wife before his coronation, the blessing of the crown, and the crowning itself, which was done after the Mass by Jouen assisted by Finaz and Mr. Jean Laborde (1805-78). ${ }^{34}$

But this support did not last for long. After the accession of Radama II, French and British interest in the island had increased significantly, and both countries sent their respective ambassadors to Madagascar. With the signing of a treaty between France and Madagascar on September 12, 1862, the advantage initially went to the French government and the Catholic mission. At the same time, internal wrangles within the royal family, especially between the prime minister's family, which was close to the late queen and to the friends of the king known as menamaso, culminated in the prime minister's assassination of the king and his friends on May 11, 1863. The king's wife, Rabodo (1814-68), took oath on the following day and became the queen, taking the name Rasoherina (r.1863-68). ${ }^{35}$

The change of guard would also change the missionary situation. The newly crowned queen and her government revoked the treaty signed with France in 1862. The treaty, which allowed foreigners to explore the island's riches, was seen as a threat to the oligarchs who had monopolized trade in the country. The decision led to tension between France and Madagascar. Through its ambassador, France threatened to leave the country and withdraw all its missionaries. The missionaries, however, unanimously refused to leave their missions.

The aftermath of Radama II's assassination did not favor the Jesuits' missionary work even though they were still recording an increase in the number of people baptized in 1864 (indeed, the harvest was so bountiful that Protestants would come to witness Catholic baptisms out of curiosity). Instead, the reign of Rasoherina saw the beginning of the government's move toward the British in terms of foreign policy and the Protestants in terms of internal policy. The prime minister and his siblings even withdrew their children from the Catholic school and sent them to a Methodist one. ${ }^{36}$

\section{Protestantism as State Religion}

After Rasoherina's death, her cousin's sister, Ramoma (1829-83), took over the throne under the name Ranavalona II (r.1868-83) and the move toward Christianity, especially Protestantism, continued to gather pace among the

\footnotetext{
34 Ibid., 455-56.

35 See ibid., 481.

36 Boudou, Les jésuites à Madagascar, 2:8.
} 
leadership. On September 3, 1868, the queen's coronation day, sampy (idols) such as kelimalaza (symbol of royal fame) and manjakatsiroa (symbol of the one and only ruler) were removed from the scene and, instead, the Bible took the place of honor on the right side of the queen. A Protestant cult began inside the palace. The public market on Sunday was banned that same year. ${ }^{37}$ Over ten years later, when recalling the story of the queen's conversion to Christianity and the building of a palace church, the prime minister insisted that "no one led her to do these things except the Spirit of God alone."38

The climax of this Protestant inclination was the baptism of the queen, which happened at the same time as that of her prime minister, Rainilaiarivony (1828-96, in office 1864-95), on February 29, 1869, and was carried out by a native pastor named Andriambelo (1829-1904). On the same day, the divorce between the prime minister and his legitimate wife was witnessed by other Protestant pastors. ${ }^{39}$ The baptism of the queen and the prime minister accelerated the expansion of Christianity in Madagascar, which had already been embraced by government officers in the capital and in the surrounding villages. ${ }^{40}$ The event was followed by the destruction of all idols and amulets owned by the people in the territory as well as the sending of evangelists as instructed by the queen and the laying of the first stone of a temple within the palace area. Jesuits welcomed the destruction of idols, but criticized the idea of a state church. For their part, Protestant missionaries denied any involvement in the creation of a state church. ${ }^{41}$ The Protestants claimed to be promoting a policy of non-conformism, but, at the same time, they also acknowledged that it was not beyond the realm of possibility that those occupying positions of authority

37 The main architect of the "Palace Church," the construction of which began on July 20, 1869 , was the prime minister, and was interpreted by many as being a purely political act. See Boudou, Les jésuites à Madagascar, 2:37-40.

38 Lovett, History of LMS, 743. On April 8, 1880, the church was opened. Representatives from some Protestant churches attended the event, but Catholics and the Society for the Propagation of the Gospel did not. During the ceremony, the prime minister recalled the story of the queen's conversion to Christianity and the building of the church within the palace whose main motive was "the queen's desire that her subjects should know the true God and the Lord Jesus Christ, and that the praying should never depart from her kingdom."

39 Ibid. This incident was related by Protestant missionaries such as James Sibree and Gustave Mondain (1872-1954).

40 Françoise Raison-Jourde, "Dérives constantiniennes et querelles religieuses (1869-1883)," in Hübsch, Madagascar et le Christianisme, 277-98, here 277.

41 See Boudou, Les jésuites à Madagascar, 2:47. Here, Boudou is quoting from the accounts of LMS missionaries in LMS, Ten Years' Review of Mission in Madagascar, 1870-1880 (Antananarivo: LMS, 1880), 69-76, 72. 
would interfere in the life of the church. They even expressed their concern that the increase in the numbers of native Christians might have come from the tendency of the Malagasy people to follow what the lehibe (elders or those in authority) do or direct them to do. ${ }^{42}$ Yet, in their report on the mission, Protestant missionaries clearly showed their enthusiasm toward the building of a church within the palace:

The Palace Church constituted a class by itself. It grew exactly like the other churches, but exerted a unique influence because [it is] situated within the palace, and attended by the queen, the prime minister, and many high officials. Yet it never gained precedence, or exercised undue authority over the rest; but in a Christian and unassuming manner always showed itself ready to assist the poorer and weaker churches, and co-operated heartily with the native missionary society in its efforts to send the Gospel to the heathen. ${ }^{43}$

For the French government, the death of Rasoherina and the accession of Ranavalona II signified the decline of its influence and, for the Catholic mission, the beginning of its hassles and persecution. ${ }^{44}$ One incident serves to confirm this observation. Toward the end of 1868 , the queen attended the official inauguration of one of the four memorial churches built by the Protestant missionaries for the victims of the persecution. For the sake of inclusivity, it was agreed that she would also attend the inauguration of a Catholic church that was being built at the same time. By the end of February 1869, the church was ready for the inaugural celebration. The queen attended the inauguration that took place on March 25 and was welcomed by the apostolic prefect, Fr. Jouen, and members of the French consulate. However, the ceremony had hardly begun when the prime minister's cousin, Rainimaharavo, who was the chief secretary of state, ordered the convoy to vacate the tribune because the queen had to leave. The queen herself did not show any resistance in following the order; she immediately stood up and showed her intention to leave..$^{45}$

The year 1868 (death of Rasoherina and accession of Ranavalona II to the throne) saw the beginning of Catholic missions around the suburbs of Antananarivo. These areas were between one and two hours' walk from the center of the capital around the hill where the palace was located and where the

\footnotetext{
42 Lovett, History of LMS, 727-31.

43 LMs, Ten Years' Review, 116 quoted in Lovett, History of LMS, 739-40.

44 Boudou, Les jésuites à Madagascar, 2:47-48.

45 Ibid., $53-56$.
} 
Jesuit mission had stood since its beginning. Finaz was one of the Jesuit pioneers in these extension missions. As he pioneered this new Catholic initiative, he encountered opposition from government officials, the Protestants, and, especially, Rainimaharavo. During an audience with the prime minister in the presence of Rainimaharavo and others on May 6, 1869, Finaz said,

I do not name anyone; but our disciples are treated like rebels for the mere fact of religion, judges are sent to them and they are taken by the hand to prevent them from joining us and they are led to the Protestants by telling them that it is in their service. ${ }^{46}$

The acquisition of land for church and school construction also became increasingly difficult for the Catholics. Despite the 1868 treaty that allowed missionaries to acquire land freely through negotiation with landlords, the government still imposed rules that required them to seek government approval. On November 9, 1871, for example, the apostolic prefect and some priests were summoned to the French consulate, in the presence of the consul Laborde and his chancellor, Albert Campan, to hear a formal instruction from the prime minister through his envoy: "If in the villages where you are called people meet in a house of some Malagasy and there is no church for that purpose, it is not necessary to inform the government. But if you or the Malagasy want to build a church, you have to inform." 47

The Jesuits denounced this new regulation. They reminded those who acted on behalf of the queen of the latter's address on the day of her coronation in which she said she was not against any "prayer," by which she meant religion. Yet, government officials would continue to use their political position or concurrently hold a church position and a political or military one in order to intimidate the Catholics. ${ }^{48}$ Victoire Rasoamanarivo often intervened with the prime minister on behalf of her fellow Catholics who needed protection against the unfriendly behavior of some Protestants.

The situation of education in Madagascar is particularly revealing with regard to the nature of the Jesuit-Protestant encounter. At the return of religious

46 See Boudou, Les jésuites à Madagascar, 2:68, my translation.

47 P. Delbosc, "Rapport du 3 Février 1881 à l'œuvre de la Propagande de la foi," as cited in Boudou, Les jésuites à Madagascar, 2:69, my translation.

48 See Lovett, History of LMS, 748; interestingly, however, not only did Prime Minister Rainilaiarivony, who had embraced Protestantism at the same time as the queen, have a close relationship with his own daughter-in law, Victoire Rasoamanarivo (1848-94), who was a fervent Catholic; he also decided to send his own son Antoine Randrava to France to receive a Catholic education. 
freedom, the Merina kingdom did not have any legislation on the schooling of children, and missionaries, such as the LMS, took care of teaching Malagasy children. Only in 1876 and 1879 did Ranavalona II ask people to register and send their children to school. At this point, the Protestant teaching program enjoyed government favor and was in fact given an edge in the competition for positions like those of governors, state officers, pastors, and evangelists. The Catholic mission program, on the other hand, was simply tolerated because of the 1868 treaty that had allowed Jesuits to open schools. In a review of their mission, Protestants showed that they were aware of the advantage that had been granted to them by the political system. They were also aware of the Jesuit reaction to such favors. In a rare show of solidarity, they renounced further assistance from the government until a just and equitable education system could be adopted. Unfortunately, such a system never materialized. On the contrary, Jesuits witnessed the queen assisting at a graduation at the College Théologique of the LMS during which she signed and distributed the issued certificates. She later assigned the graduates to some important offices in her government. ${ }^{49}$

At the center of Protestant education was the Bible, which was taught from a Protestant perspective. ${ }^{50}$ Catholic children who were sent by their parents to Protestant schools were not allowed to manifest any association with their own church. The Jesuits were accused of jealousy when they tried to fight against this system. The conflict was not only among the missionaries or Catholic and Protestant teachers but also among their respective students and their parents, and it often turned violent. Historian Adrien Boudou relates a number of incidents where Catholic and Protestant students engaged in violence, most of them outside Antananarivo. He also mentions a request by some Catholic parents to the queen, asking not to be separated from their children when going to church simply because they were Catholics as their children, who studied in a Protestant school, had to go to a Protestant church. ${ }^{51}$

Both Protestant missionaries and Jesuits also became involved in activities such as writing the history of Madagascar and of their respective missions, as well as scientific works. The Jesuits, for example, became known in Madagascar because of the work of Fr. Désiré Roblet (1828-1914), who produced a geographical map of the territory. The Jesuits also took up the work of Laborde (consul of France) after his death in 1878, which involved constructing a meteorological observatory.

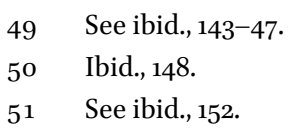


In the same period, two separate publications-one Catholic, the other Protestant - were used by the Catholic and Protestant missionaries to launch attacks against each other. In 1874, Jesuit Pierre Caussèque began a review called Resaka (Conversation). The mission took this initiative in response to the Protestant review Teny soa (Good words), which had already begun nine years earlier, in 1865, and was used by Protestant missionaries to attack Catholicism. Using fictional stories, Caussèque countered the Protestant attacks by describing what he considered to be the essence of the Catholic faith and of Malagasy Catholicism, while also exposing what he judged to be Protestant errors. Eventually, the Protestants had to cease their attack on the Catholic faith and on the Malagasy Catholic faithful. One of the principal attractions in Resaka was the fables written by Fr. Rahidy, the first Malagasy Jesuit priest, which attacked the prime minister's family. Out of anger, the prime minister would refer to him by using the name of his tribe, Sakalava. ${ }^{22}$

Despite the tense atmosphere, Christianity developed on both denominational sides for the next twenty-two years, not only in terms of numbers but especially in terms of diversity. Antananarivo, where the palace is located, became the center of missionary activity. Missionaries were first sent there before they could spread around the country. The sacred character of the monarch and his or her protection ensured people's adherence to Christianity. It was because of this that priests and pastors competed around the throne in controversies, songs, and teachings. In addition to the LMS and the Catholics, a number of other Christian denominations arrived in the country during this time. The Anglican Church, represented by the Church Missionary Society (CMS), had already begun work in the northern Madagascar in 1862, and in 1866, two Lutheran pastors arrived in Antananarivo to learn the local language. A year later, after negotiation with the LMS, they were allowed to evangelize in the southern part of the country and in the region of Vakinankaratra, 150 kilometers from the capital. The Quakers also came to the country in the same period to join the LMS in the area of education. They formed the beginnings of L'Église des Amis, later translated in Malagasy as Frenjy.

The government's adoption of Protestantism as the state religion affected the Catholics politically. Many government officials whose children had been baptized in the Catholic Church and educated in the Catholic schools were

52 Ibid., 165 . The relationship between tribes in Madagascar in the nineteenth century must be understood in the context of the unification of the country that was begun by the Merina kingdom and supported by France, and which other tribes such as the Sakalava were against. Fr. Rahidy's father was among those who fought against the unification in 1830. He was captured, brought to Antananarivo, and had to redeem his liberty. 
forced to remove their children from their schools. As a result, from this time onward, the Catholic population in Madagascar was composed of ordinary citizens, whereas the Protestant Church was associated with the members of the country's elite and their families. ${ }^{53}$ Schools constituted one of the major means of evangelization. The LMS controlled the education of the leaders' children. The best students were recruited into their theological institute and later became evangelists. The LMS also opened their first hospital in 1865, which was followed by a medical academy that was opened in collaboration with the Lutherans in 1885. Schooling or education, according to historian Françoise Raison-Jourde, not only aimed to integrate children into the church but also to prepare them to become elites for the state. ${ }^{54}$

\section{The Two Wars and Colonization}

Toward the end of the nineteenth century, during the reign of Ranavalona III (1861-1917, r.1883-96), the tension between the French and the Malagasy government, historically referred to as the "Franco-Hova"55 conflict, was growing in intensity. On the one hand, the French wanted to claim what they called droits historiques (historical rights).${ }^{56}$ On the other hand, the Malagasy government was determined to keep both its independence and sovereignty over the country. The tension led to two wars in $1883-85$ and $1894-96$.

As a result of a French attack in the northwest of Madagascar on May 25, 1883, all French citizens in the territory, including missionaries, were asked to leave the country immediately. The Jesuits went to seek the intervention of the Anglican bishop of the time, Rev. Robert Kestell-Cornish (1824-1909), after being denied an audience with the prime minister. Although the bishop declared himself powerless, he did ensure that the Jesuits' letter was sent to the prime minister. But this too was in vain. ${ }^{57}$ Catholic missionaries, including the Jesuits, the Christian School Brothers, and the Sisters of St. Joseph of Cluny, left

53 See Haja Rajoelison and Bruno Hübsch, "L'instauration de la liberté religieuse (1861-1868)," in Hübsch, Madagascar et le Christianisme, 259-76, here 273-76; see also Lovett, History of LMS, 783-91.

54 See Raison-Jourde, "Dérives constantiniennes et querelles religieuses," 292.

55 Hova can have two meanings: first, it indicates the higher caste within the Merina ethnic group, especially those in the elite position; second, it may also indicate the Merina ethnic group itself.

56 See Boudou, Les jésuites à Madagascar, 2:230. These are the rights to ownership over the buildings and lands as well as the freedom of trade.

Ibid., 258. 
Antananarivo on May 30, 1883. According to Boudou, the prime minister was not opposed to Catholic missionaries staying in the country, but he was under pressure from those surrounding him, including a hostile population and the Protestants. ${ }^{58}$ The fate of the Jesuits who went to the regions of Fianarantsoa and Ambositra in the south was even worse. Some were imprisoned before being sent away, others fell sick on the road, and two died while on the journey.

The only positive thing to come out of the missionaries' departure was the fact that their absence forced lay Malagasy Catholics to take charge of the missionary work. On the eve of their departure, Caussèque gathered all Christian leaders of the different movements that would later form the Catholic Union and instructed them on how they could continue to lead prayer in the church, to instruct children in the school, and so on. Victoire Rasoamanarivo, who would be beatified by John Paul II (r.1978-2005) in 1989, was among the leaders during this crucial time. ${ }^{59}$ The departure seemed to be a victory for the Protestant missionaries and their faithful. The latter would invite Catholics to join them. Sometimes they did this using threats, accusing Catholics of being friends of traitors, meaning France and its citizens, and especially, missionaries. Despite the threats, however, under Victoire's leadership, the Catholic Union became ever stronger and was able to sustain the life of their church around Antananarivo and in the south of the country.

The missionaries returned to Antananarivo after the signing of a peace treaty between France and Madagascar on December 17, 1885, which was later ratified in Antananarivo. The Jesuits resumed their work with other missionaries. Fr. Jean Baptiste Cazet (1827-1918), formerly apostolic prefect, also came back from France as Mgr. Cazet. While still in France, he was consecrated bishop and appointed apostolic vicar of the Madagascar mission. Madagascar became an apostolic vicariate and now had a bishop as its head. Cazet entered Tamatave on April 5, 1886. During Holy Week, he was received with great joy by the faithful in Antananarivo under the leadership of Victoire Rasoamanarivo. The celebration of Easter on April 25 seemed to conclude the return of the missionaries. It was followed by the bishop's official visit to the prime minister. ${ }^{60}$ Subsequently, the Jesuits resumed all the works they had left behind: the school, the royal observatory, topography, research in philology and history, construction of the bishop's house in Antananarivo and the cathedral in Fianarantsoa.

\footnotetext{
58 Ibid., 261 .

59 Ibid., 275 .

6o See ibid., 291-300.
} 
The mission's resumption after two years of absence was not without challenges and difficulties, however. Politically, article 1 of the newly signed treaty allowed the French government to represent Madagascar in foreign relations. From then on, France would have a so-called résident général in Antananarivo for that purpose. The first person to occupy this prestigious office was Charles Le Myre de Vilers (1833-1918), whose arrival in Antananarivo had already generated some controversy between Protestants and Jesuits. A former LMS missionary related that the Jesuit fathers asked to join the new résident on his trip to the capital, but were denied the permission to do so. According to the missionary, the résident publicly declared that he came to the country not to give special support to the priests but "to be the friend of all and of all beliefs, and to give real help to Madagascar on the road to civilization." ${ }^{11}$ The Jesuits refuted this claim by arguing that they arrived in Antananarivo earlier than the résident général and thus did not need any special support from him. Indeed, his relationship with the Jesuits was far from smooth, and when asked by the apostolic vicar why this was the case, he said he was afraid that the Protestants would complain to their fellow French Protestants, and he would be recalled from his job. ${ }^{62} \mathrm{He}$ finally left Madagascar on June 28, 1889 and was replaced by Maurice Bompard (1854-1935), although he returned to the country on the eve of the second war. ${ }^{63}$

The Catholic missionaries, Jesuits included, had to face some material challenges as well. Some of their residences and schools had been vandalized during their absence. Fortunately, the main Jesuit residence in Antananarivo was spared from destruction due to the care and diligence of Rainitsimbazafy, who was minister of the interior at the time. Elsewhere, in Fianarantsoa and Ambositra, the Jesuits had to deal with some Protestant faithful who used their position to intimidate them. The Jesuits were not allowed to enter their residence or church. Their keys were confiscated and they were asked to show proof of permission from the government. ${ }^{64}$ However, despite all these difficulties, the Jesuits, alongside other missionaries, slowly and patiently resumed their work under the leadership of Cazet. Their mission can be summed up in the following words of historian Pierre Suau (1861-1916):

Foreigners, if not indifferent, to diplomatic incidents [...], deaf to Protestant clamor, the missionaries, during these nine years of truce

\footnotetext{
$61 \quad$ Boudou., Les jésuites à Madagascar, 2:303, my translation.

62 Ibid., 2:305.

63 See ibid., 2:311.

64 See ibid., 315.
} 
(April 1886-October 1894), employed themselves in the apostolate of the Imerina and the Betsileo with a holy generosity. From 146, in 1880, their posts amounted, in 1893, to the figure of 443; their pupils, from 12,60o in 1886 , increased in 1893 to 26,360 ; and on that date they had forty thousand faithful baptized and 105,419 adherents. God alone knew, and he alone will reward the efforts that these conquests had cost. ${ }^{65}$

During this period, and though it remained difficult, the relationship between Protestant missionaries and Jesuits seems to have improved. In the school, for example, unlike before, European Protestant missionaries would only intervene with reservation. Instead, they would sow ideas of a movement that they would not lead themselves, but which would be followed by the native pastors, state officers, governors, and civil servants, and almost all the Protestants. The missionaries of both sides only met sur le sentier de la guerre (on the battlefield). ${ }^{66}$ They were so different in everything: "doctrine, formation, lifestyle, nationality, the way of understanding the apostolate and Christian life, and even prejudices!" 67 Boudou describes the situation in the following words:

Those of the Protestants against the "idolatrous" papists in general, and against the "sinister Jesuit priests" in particular, judged capable of all bad blows. Those of the Catholics, too, against their adversaries, of whom they were a thousand times justified in detesting doctrines, but whose inward dispositions and circumstance generally escaped them; they judged it too logically, where abstract logic is often outside its domain, and they were too inclined to believe in the bad faith of their opponents, whereas these Anglican clergymen, independent ministers or Quakers, these Lutheran pastors wore without personal responsibility the weight of the chains forged by their Reforming fathers, and believed in fighting popery to give God a supreme homage. ${ }^{68}$

Despite the kinds of antagonistic attitudes just described, there were occasions or incidents where Jesuits and Protestants cooperated with each other. On August 16, 1886, for instance, Jesuits and Catholic faithful buried the bodies

65 Pierre Suau, La France à Madagascar: Histoire politique et religieuse d'une colonisation (Paris: Librairie Académique, 1909), 185-86, quoted in Boudou, Les jésuites à Madagascar, 2:319, my translation.

66 Boudou, Les jésuites à Madagascar, 2:320.

67 Ibid.

68 Ibid., 2:320-21, my translation. 
of Fr. Gaston de Batz (1836-83) and Br. Martin Brutail (d.1883), both of whom had died during the missionaries' departure. Mgr. Cazet presided over the celebration. The résident général and a number of Europeans were also present; so were five Protestants, among them the British vice-consul W. Clayton Pickersgill (1845-1901), the Rev. J. Wills of the LMS, and Rev. Ankers from the Norwegian Lutherans. Caussèque related the guests' admiration of the missionaries' tomb, especially its simplicity and architecture. ${ }^{69}$ Another example of cooperation concerns that between the Jesuits and an independent pastor named Rev. James Richardson (1844-1922) in caring for the lepers at Ambahivoraka. After the departure of the Catholic missionaries, Richardson told Caussèque that he kept hearing a voice at night asking: "What will happen to these poor lepers? Who will save them?" This thought continued to haunt him. So, the following Sunday, he decided to go to the leper house. He gave money to the sick and continued to do so until the Jesuits' return, which was facilitated by the help of his friends from Britain, and he did not ask them to leave the Catholic faith. Instead, he offered to pray with them on a number of his visits if they would allow him to do so. Caussèque concluded this story saying, "Blessed is the one who inspired a Minister of the LMS, Mr. J. Richardson, with such devotion. May this act of charity attract to its author and his collaborators the grace which saves and the reward which will have no end!"70

Fruitful though this collaboration might have been, Jesuit work in Madagascar and that of other missionaries would again come to an end with the onset of the second Franco-Hova conflict, which later evolved into a full-fledged war. However, before the war broke out, the missionaries' work was affected by a series of developments, the first of which was the Zanzibar agreement between France and Britain on August 5, 1890, according to which Madagascar became a French protectorate and France recognized Zanzibar as a British protectorate. ${ }^{71}$ The agreement ensured religious tolerance, freedom of cult and of teaching to both Protestant and Catholic missionaries from the two countries. The second development was the death of Victoire Rasoamanarivo, who had been a pillar of the Catholic Church in Madagascar and had exerted influence over the prime minister, on August 21, 1894. Her funeral took place at the Cathedral in Antananarivo where Protestants and public officials like the résident général joined the Catholics to honor her. ${ }^{72}$ The national sovereignty of the Merina kingdom was in danger due to the 1890 treaty. France was unable to obtain

\footnotetext{
69 See ibid., 2:321.

$70 \quad$ Ibid., 2:322, my translation.

71 Ibid., 2:375.

72 Ibid., 2:387.
} 
the Malagasy government's consent to implement the treaty and decided to impose the protectorate by force. The résident général urged all French residents, including the missionaries, to leave the country. Mgr. Cazet, on behalf of the missionaries, initially refused to leave. They finally left for the east coast, then moved on to La Reunion and Mauritius after the failure of the negotiations between the prime minister and the résident général. The war broke out in December 1894 in Tamatave (east coast) and Majunga (west coast). French soldiers conquered Antananarivo on September 30, 1895, and a peace treaty was signed on October $1 .{ }^{73}$

The missionaries were already back in Antananarivo by the end of 1895 . During their absence, like in the aftermath of the first war, a number of their residences and works had been looted and destroyed. At this point, Madagascar became a French colony, and an insurrection began, conducted by the Menalamba rebels, in which European missionaries, Catholics and Protestants, were the victims. ${ }^{74}$ Menalamba was a nationalist movement that fought against the foreign invasion and wanted to restore the monarchical regime. In the west of Antananarivo, a Quaker pastor, William Johnson (1842-1895), with his wife and daughter, were killed by the rebels. A Jesuit priest, Joseph de Villèle (1851-1939), was saved by his students. ${ }^{75}$ Both Protestants and Catholics seemed to have arrived at the same interpretation of the ongoing insurrection. A Protestant pastor interpreted the movement as a purely pagan reaction against those occupying the country, whose victory had turned the system of the ancestral idols upside down; in his view, it was a reaction against all that was European, particularly against all that looked Christian. For Jesuit historian Fr. Victorin Malzac (1840-1913), "the first aim of the rebellion was to exterminate the white, first the French citizen who became their masters, then other foreigners who, in preaching their religion, contributed to this enslavement, and the second aim was to revive the practice of idolatry of the past."76

The relationship between Protestants and Catholics during the insurrection and colonization period was more complex than had previously been the case. After the signing of the peace agreement, British missionaries went to see General Jacques Duchesne (1837-1918) who led the war and the conquest of Antananarivo, and assured him of their "loyal collaboration in the work of pacification and civilization that France was to undertake." ${ }^{77}$ However, despite this

\footnotetext{
73 Ibid., 2:399-400.

74 See ibid., 2:438.

75 Ibid., 2:416.

76 Ibid., 2:417-18.

77 Ibid., 2:423.
} 
promise, a good number of Protestant missionaries who could not cope with the new situation decided to leave the country. The departure of the résident général Hippolyte Laroche (1848-1914), who was a Protestant, also affected the Protestant missionaries. They even accused the Jesuits of instigating his departure. ${ }^{78}$ Laroche's successor, General Joseph Gallieni (1849-1916), was known as pacificateur et organisateur (pacifier and organizer). The first decision he made as soon as he came to office concerned the abolishment of the Hova hegemony. He executed a number of members of the royal family and sent others into exile. On February 27, 1897, he announced the end of the Merina kingdom by sending Queen Ranavalona III into exile. ${ }^{79}$ All of this was opposed by the Protestants. They accused Mgr. Cazet of being the main instigator of these actions and, in connection with this, they recalled his attempt to convert the queen to Catholicism before she was exiled. ${ }^{80}$ The British-Protestant and French-Catholic split, exemplified in the phrase qui dit Français dit Catholique, qui dit Protestant dit Anglais (who says Catholic means French, who says Protestant means English), and whose spread the Jesuits were accused of, became even more pronounced. But the Jesuits categorically denied being the origin of such a formula. The French victory seemed to be the end of the BritishProtestant hegemony, although the French government always insisted on its neutrality on the matter of confession in Madagascar during this period. Protestant missionaries, native pastors, and Malagasy faithful began to do everything possible to prevent Catholic supremacy. In school, for example, law 296, which forbade students from moving from one school to another, continued to be enforced by some Protestant leaders. ${ }^{81}$ The same law would be abolished by the résident général on April 17, 1896. The same year saw the arrival of the Société des Missions Evangéliques de Paris that took over the works left behind by British Protestants. It first sent two delegates-Pastor Henri Lauga and Professor Frédéric-Hermann Kruger (1851-1900) — to investigate the situation of the Protestants in Madagascar. Their report, entitled "La liberté religieuse à Madagascar," published by the Journal des missions evangéliques, denounced the persecution of Protestants by the Jesuits. The latter were accused of systematic harassment, abuse of power, intimidation, threats, and violence, and

\footnotetext{
78 Ibid., 2:454.

79 Ibid., 2:456.

$80 \quad$ Ibid., 2:457.

81 It is to be noted that, in this period, the different Protestant denominations already owned quite a substantial infrastructure and personnel; the LMS, for example, had forty missionaries, 1,400 churches, 1,290 schools, three colleges for the formation of pastors and indigenous teachers, two colleges, and two hospitals. See Boudou, Les jésuites à Madagascar, 2:429.
} 
of using all means to protect the interests and honor of France. These means included arbitrary incarceration and taking over churches that belonged to the Protestants. ${ }^{82}$ According to the report, the Jesuits were helped by state officers in stealing Protestant temples. In addition, an interview with Lauga on his arrival in France on December 13, 1896 portrayed his negative view of the Jesuits. When asked about his opinion on the work of Catholic missionaries, he said:

Certainly, far from me is the thought of making the trial of a religion that is not mine, but let me tell you how disgusted I was when I saw the Jesuit fathers - who form the unanimity of the Catholic missionaries in Madagascar-continue, under the guise of propagating their faith, the grabbing of the Malagasy soil. ${ }^{83}$

The Jesuits' defense against this accusation was based on what they called "right and fact": 84 the temples were constructed by the villagers under the government's direction; by right, they belonged neither to the government nor to the missionaries, but to the people who built them. If a group of Protestants or a majority of them declared themselves to be Catholics, nobody could deny them the right to convert their temple in the same way. In fact, in the years 1896 and 1897, the military authority allowed five or six temples in Antananarivo to be converted into Catholic churches at the request of the inhabitants who wanted to move to the Catholic faith. The conversion of temples into Catholic churches also occurred in places outside Antananarivo. However, on March 26, 1897, General Gallieni ordered the Jesuits to return the so-called grabbed lands to their owners. ${ }^{85}$

\section{Conclusion}

The nineteenth-century encounter between Jesuits and Protestants in Madagascar was shaped by the politics of the monarchical regime, especially its relationship with Europe and with Christianity. Although Protestants had the upper hand early on in the century and had already planted the seeds of Christianity in Madagascar, the return of religious freedom in 1861 after twenty-five years of persecution did not work in their favor. On the contrary, Jesuits quickly

\footnotetext{
$82 \quad$ Ibid., 2:471-73.

83 Ibid., 2:483, my translation.

84 Ibid., $2: 478$.

85 See ibid., 2:480-81.
} 
took advantage of the young king Radama II's openness to European civilization and his inclination to Catholicism. But that advantage did not last long. The decision of the king's successors to embrace Protestantism, symbolized by the baptisms of Queen Ranavalona II and Prime Minister Rainilaiarivony in 1869, would affect the progress of the Catholic faith within the Merina kingdom and beyond. However, French colonization of the island in 1896 reversed the fortunes once again, as Catholics profited from Madagascar becoming a French colony. The accounts from this period clearly reveal that both Jesuits and Protestants knew how to take advantage of favorable political situations in nineteenth-century Madagascar.

The status of Christianity in central Madagascar continues to reflect some of the nineteenth-century realities mentioned in this chapter. The association of some churches or parishes that are around the queen's palace with a particular caste, for example, dates back to the pre-colonial and colonial periods. On the national level, political leaders take great care to maintain a balance between Catholics and Protestants in the composition of the government. Similar efforts to include coastal and central areas in government also reflect the need to manage tensions dating back to the missionary period of the nineteenth century.

\section{Bibliography}

Boudou, Adrien, Les jésuites à Madagascar aux XIXe siècle. 2 vols. Paris: Gabriel Beauchesne et ses Fils. 1940

Ellis, William. Three Visits to Madagascar during the Years 1853-1854-1856. London: John Murray. $185^{8}$.

Horne, C. [Charles] Silvester. The History of the L.M.S. 1795-1895. London: London Missionary Society. 1894.

Hübsch, Bruno. "Difficultés des missions Catholiques à Madagascar (1820-1861)." In Madagascar et le Christianisme, edited by Bruno Hübsch, 241-56. Antananarivo: Editions Ambozontany. 1993.

Hübsch, Bruno ed. Madagascar et le Christianisme. Antananarivo: Editions Ambozontany. 1993.

London Missionary Society. Ten Years' Review of Mission in Madagascar, 1870-1880. Antananarivo: LMS. 1880.

Lovett, Richard. The History of the London Missionary Society, 1795-1895. London: Oxford University Press. 1899.

Raison-Jourde, Françoise. "Dérivés constantiniennes et querelles religieuses (18691883)." In Madagascar et le Christianisme, edited by Bruno Hübsch, 277-98. Antananarivo: Editions Ambozontany. 1993. 
Rajoelison, Haja and Hübsch, Bruno. "L'instauration de la liberté religieuse (1861-1868)." In Madagascar et le Christianisme, edited by Bruno Hübsch, 259-76. Antananarivo: Editions Ambozontany. 1993.

Rasoamiaramanana, Micheline. "Le rejet du christianisme au sein du royaume de Madagascar (1835-1861).” In Madagascar et le Christianisme, edited by Bruno Hübsch, 217-40. Antananarivo: Editions Ambozontany. 1993.

Suau, Pierre. La France à Madagascar: Histoire politique et religieuse d'une colonisation. Paris: Librairie Académique. 1909. 


\title{
Jesuit-Protestant Encounters in Colonial Congo in the Late Nineteenth Century: Perceptions, Prejudices, and the Competition for African Souls
}

\author{
Toussaint Kafarhire Murhula, s.J.
}

This chapter analyzes the conditions under which Jesuit and Protestant missionaries encountered each other in the Congo in the late nineteenth century. It aims to explain the conflictual relationships that ensued and to address the questions of competition that stemmed from their mutual prejudices and biased perceptions.

In the late nineteenth century, King Leopold II (1835-1909, r.1865-1909) repeatedly asked the Jesuits to take part in his colonizing project in the Congo. However, they were reluctant to do so not only because of the negative opinion they held of the king's colonial ambitions but also because other Catholic missionary orders had been working in the Congo since 1881 . Why, then, did the Belgian Jesuits eventually decide to become involved in Leopold's colonial project despite their previous reluctance to do so? What had changed by 1893, when they agreed to the king's request, and what imperatives were they responding to? Answering these questions will help explain the animosity that resulted from encounters that were marred in mutually distorted perceptions, hostile interpretations, and conflicts of interest.

This essay is divided into four parts. The first part sets out the political context of the late nineteenth century, a period in which the European powers were scrambling for colonial supremacy in Africa. The second part outlines the discussion process that eventually led the Jesuits to take part in the project as civilizing agents. The third part analyzes the way in which Jesuits and Protestants perceived each other. On the one hand, the political connections and preferential status of the Roman Catholic Church within the colonial structure gave the Jesuits a sense of entitlement in fending off the spread of the Protestant "heresy." On the other, the Protestant Baptist missionaries saw this group of Catholic missionaries reaping temporal privileges from the state as imposters posing as religious. The chapter concludes by reflecting on the foregoing analysis and discussing future lines of enquiry. 


\section{Setting the Political and Historical Context}

The conflict-ridden background to the Jesuit-Protestant encounter in the Congo coincided with the late nineteenth-century colonial scramble for Africa. Competitions and rivalries among the European colonial powers would determine both the kinds of social policies that were adopted and the missionary group to be sent to a given territory and supported by the state. ${ }^{1}$ Thus the history of the nineteenth-century penetration of Christian missionaries into Africa is, to a large degree, the history of European colonization. ${ }^{2}$

Belgian colonial rule in the Congo was characterized by a unique structure of institutionalized violence and unprecedented brutality, where the colonial agents (administrators, soldiers, and priests) symbolized the very raison d'être of the colonial state, namely to maximize the commercial interests and profits of the multinational Western companies that ventured into the Congo in the king's name. To meet their goals, the colonial agents had to push the Congolese natives to deliver a daily quota of rubber and ivory tusks, the precious global commodities of the day. The African colonial experience consequently signified the Western project of reorganizing both the geographical space and the minds of native populations and, concomitantly, of forcing Africans into Western modernity.

At the 1884 Berlin Conference, Leopold was granted permission to occupy the vast territory of the Congo, with international recognition of the king's colony to be provided at a later date. In order to raise the much-needed capital to begin exploiting the natural resources in his newly acquired property, Leopold invited multinational companies to invest in the Congo, calling, at the same time, on Catholic missionaries to carry out the work of "civilization"

1 Joseph Conrad, Heart of Darkness \& Selections from the Congo Diary (New York: Modern Library, 1999). This novella provides a powerful allegory of the colonial horrors and brutalities. In the introduction to this edition, Caryl Phillips argues that Conrad's "iconic tale of rescue $[. .$.$] contains a powerful meditation on the relationship between 'civilization' and$ 'barbarity." See the "Introduction," in Conrad, Heart of Darkness, xi-xviii. Also, Adam Hochschild's King Leopold's Ghost: A Story of Greed, Terror, and Heroism in Colonial Africa (New York: First Mariner Book, 1999) provides another scholarly analysis that depicts the historical background to the colonial for-profit business and the related atrocities that accompanied these ventures in the Congo. See also Ruth Mayer, Artificial Africas: Colonial Images in Times of Globalization (Hanover: University Press of New England, 2002) and David Van Reybrouck, Congo: The Epic History of a People (New York: HarperCollins, 2014).

2 V.Y. [Victor Yves] Mudimbe, The Invention of Africa: Gnosis, Philosophy, and the Order of Knowledge (Bloomington: Indiana University Press, 1988), 45-46. 
(i.e., education). The state would provide soldiers to protect these agents and guarantee them a propitious working environment. Thus land came to be granted by the state to multinationals and to the church thanks to a royal decree that destroyed the traditional African systems of communal ownership of land and its products. The decree allowed the colonial administration to expel the natives from their lands by declaring any "vacant land" to be the property of the state. ${ }^{3}$ But the colonial definition of unoccupied land, as American historian Catherine Ann Cline argues, was contrary to the customs of the land, a form of trickery that gradually led to the imposition of a labor tax on the population. This self-financing policy undoubtedly raised vast amounts of revenue for the king and, eventually, the state; the human toll, however, was utterly appalling. ${ }^{4}$

How did King Leopold II of the tiny Belgian realm manage to secure the vast territory of the Congo as his personal property when European powers, such as France, Britain, Germany, Spain, and Portugal, were competing for access and control of smaller colonial territories in much drier regions? When they met in Berlin in 1884, the goal of these European powers was not only to resolve their competing claims and interests over the newly discovered Congo River Basin but also to regulate trade relations on the continent. ${ }^{5}$

Leopold emerged on the international scene at the Berlin Conference as a benevolent, selfless leader. He presented himself as being interested only in opening up the heart of Africa to civilization, free trade, and Christianity. In 1876, for instance, he had hosted the International Geographical Conference in Brussels, the outcome of which led him to found the International African Association (IAA). Three years later, in 1879, Leopold commissioned the famous Welsh American explorer Henry Morton Stanley (1841-1904), under the banner of the International Association of the Congo (IAC), to establish treaties with local leaders and commercial outposts in the Congo. ${ }^{6}$ Stanley left on his third trip for the Congo in 1879 - after the first to find the lost David Livingstone (1813-73) in 1871 and the second to explore the Congo River Basin (1874-77) as an agent of Leopold. During this trip, he mapped the country's physical

3 Hochschild, King Leopold's Ghost, 111-19.

4 Catherine Ann Cline, "The Church and the Movement for Congo Reform," Church History: Studies in Christianity and Culture 32, no. 1 (1963): 46-56, here 48.

5 Kevin C. Dunn, Imagining the Congo: The International Relations of Identity (New York: Palgrave Macmillan, 2003), 22.

6 Victor Yves Mudimbe, The Idea of Africa (Bloomington: Indiana University Press, 1994), 105; see also Dunn, Imagining the Congo, 21-23. 
terrain and established some commercial outposts (1879-84), thus producing the Congo that was to be handed over to the king at the Berlin Conference.

Since the European powers intended to keep the Congo River Basin for the collective exploitation of all, awarding the management of the Congo to Leopold was a strategic move designed to create an "international colony" with the king of Belgium at its helm. Although the IAC was a private company and not a government, the international community granted it recognition and gave Leopold juridical sovereignty over the entire region. Hence, with the agreement and the protection of the European powers, the Berlin Conference allowed Leopold to collapse his IAC into the Congo Free State (CFS) on May 29, 1885. As political scientist Kevin Dunn observes, Leopold was able to weather the storm of those contesting this move by maintaining his image as a philanthropist fighting the Arab slave trade and by continuing to make promises of free trade and neutrality.

To convince the leaders of the European powers that he could run the Congo in the interests of all, Leopold cleverly used the good faith of the Protestant missionaries who had been working in the Congo since 1878 and who were able to influence public opinion in their respective countries. To ensure their support, he promised them freedom of religion in the Congo, and thus, as historian Ruth Reardon Slade explains, "it was not surprising that the Protestants were on the side of Leopold II," since the Catholic missions were still closely connected with the political ambitions of France and Portugal. ${ }^{7}$ The Protestant missionaries, for their part, feared that the Portuguese would use their ius patronatus (right of patronage) to achieve missionary sovereignty in the Lower Congo. The papal establishment of the ius patronatus over all countries discovered or to be discovered granted European kings the right to dispossess non-Christians of their lands and became, in the international context of the day, a way to justify the concept of terra nullius (no-man's-land).

It is important to say a word about the right of patronage here. From the fifteenth century onward, the missionaries' agenda was much more complex than the simple transmission of the Christian faith, since the missionaries themselves were part of a political process that created and extended European sovereignty over newly discovered territories. Through his bulls Dum diversas (1452) and Romanus pontifex (1455), Pope Nicholas V (1397-1455, r.1447-55) had granted the Portuguese king the right to invade and occupy pagan kingdoms

7 Ruth Slade Reardon, "Catholics and Protestants in the Congo," in Christianity in Tropical Africa, ed. C.G. [Christian Goncalves] Baëta (Oxford: International African Institute and Oxford University Press, 1968), 83-100, here 85 . 
or dispossess them of private property and land. Christian kings consequently acquired the right to enslave Muslims, pagans, and black people. ${ }^{8}$

The pope delegated the power to evangelize throughout the world to Spain in 1508 and to Portugal in 1514- the two major colonial powers of the dayboth of which possessed important maritime fleets. As one scholar has noted, the resulting system of "patronage," which was an immediate solution to the problem of evangelization, nevertheless contained the seed of political and economic conflicts of interests among the powers opposed to the church's evangelizing mission. It was only when other colonial powers began to compete and when the financial and material means of Portugal and Spain began to decline that the Roman Catholic Church decided to create the Congregation de Propaganda Fide in 1622 with the goal of centralizing and guiding the missions. At that point, the Catholic Church began to go against the patronage system. ${ }^{9}$

Accordingly, the king was responsible for funding evangelization work and the building of churches; he also had a say in the appointment of bishops. ${ }^{10}$ As a result of this development, the Protestants came to believe that they had discovered a potential ally in the person of Leopold, who had promised to maintain freedom of religion in the Congo. On this specific point, political scientist Marvin D. Markowitz notes,

Leopold welcomed and cultivated the support of the Protestant missionaries, and aided their efforts to build mission stations in the Upper Congo. There can be little doubt that the aid of the Protestant missions

$8 \quad$ Mudimbe, Invention of Africa, 45 .

9 The aim in creating the Congregation de Propaganda Fide in 1622 was, for the Vatican, to centralize and reclaim control over the missions in revocation of papal bulls that delegated this responsibility to European superpowers during the fifteenth and sixteenth centuries. The Catholic Church continued, however, to depend on European countries, at least for granting the right to their missionaries to travel and work in the colonies. See Yves Krumenacker, “Le XvıIIe siècle: Éveil protestant et déclin catholique?" Cahiers d'études du religieux: Recherches interdisciplinaires 1 (2008); posted online on January 25, 2008 at http://cerri.revues.org/242 (accessed May 22, 2017).

10 In his Idea of Africa, 30-33, Mudimbe discusses the way in which different papal bulls dealt with this right of patronage, imparting the responsibility to evangelize newly discovered territories to Catholic kings of Spain and Portugal. Among others, the documents included Romanus pontifex (1454), Inter caetera (1493), Universalis ecclesiae (1508), and Dudum pro parte (1516). 
had been helpful, if not instrumental, in obtaining the establishment of Leopold's dominion in the Congo under the Berlin Act of $1885 .{ }^{11}$

Once he had been granted the Congo, Leopold went on to use both the state and the church, that is, the soldiers and the missionaries, to achieve his colonial goals. These consisted in spreading European civilization, making room for free commerce, and bringing the light of Christianity to the Africans. As "effective" occupation of the territory was required in the Berlin Conference Act in order to claim colonial authority over a territory, the king not only needed more military men from Belgium; he also sought to form a military body from among the natives in the Congo. Hence, by adopting a strategy of cultivating and redesigning the territorial space and the natives' minds on the basis of modern Western rationality, Leopold sought to orient both the colonial agents and the local populations to support his project.

Yet, to achieve his vision, the exclusive contribution of Belgian Catholic missionaries, especially the Jesuits, was needed. The question therefore remains why the Jesuits came to accept the king's request, enabling him to blend the Berlin Conference's requirement of effective occupation with his ambition to exploit the colony for commercial profit.

\section{The Jesuit Decision to Take Part in Belgium's Colonial Project}

The generally accepted narrative is that the Jesuits, who arrived in the Congo fifteen years after the Protestants, enjoyed a privileged position in the country until after the Second World War thanks to their Belgian nationality and assumed patriotism. However, this narrative fails to acknowledge the existence of conflicts between the Catholic Church and the colonial state on the one hand, and the numerous cases of collaboration between Jesuits and Protestants within the Congo on the other. Although personal acts of Christian generosity between individual Jesuits and Protestants cannot override the existing pattern of conflict, this essay contends that, more than anything else, it was national patriotism and international competition, more than anything else, that informed state policies and the individual attitudes of these missionaries. The Jesuits' privileged position put the Protestants at a disadvantage, allowing them to turn a blind eye to the atrocities perpetrated by the colonial

11 Marvin D. Markowitz, "The Missions and Political Development in the Congo," Africa: Journal of the International African Institute 40, no. 3 (1970): 234-47, here 234. 
agents against local populations, whereas the Protestants saw an opportunity to denounce an unacceptable system of intolerable violence. Political scientist Patrick Boyle cogently summarizes what was at stake in the colonial Congo state, namely the "respective status of Catholic and Protestant missionaries in the territory, as well as the practice among EIC (État Indépendant du Congo) [Congo Free State] agents of placing Congolese children in military camps called colonies scolaires [school camps]."12

The first group of Jesuits, which was made up of only three men - two priests, Emiel van Hencxthoven (1852-1906) and Jean-Baptiste Dumont (1843-93), and one brother, Edmond Lombary (1865-1918) — departed from Antwerp on March 6, 1893. A day before their departure, Mass was celebrated in the Cathedral of Our Lady of Antwerp with their families in attendance. Other Jesuits were also present at Mass, as were some officials representing the CFS. These three groups represented the state, the Catholic Church, and the broader public - the different stakeholders in the colonial business in the Congo that novelist Joseph Conrad (1857-1924) would later term "the heart of darkness." The three men arrived at their destination more than three weeks later, on March 30, 1893. A second group then set out on April 6, 1893 to join the first three pioneers. This second group was composed of Father Edouard Liagre (1853-99), Emile de Meulemeester (still a scholastic), and two brothers, Justin Gillet (1866-1943) and Frans de Sadeleer (1844-1922). The group also contained two laymen, Charles Petit and Auguste van Houtte.

While the king was anxious to achieve his dream in the Congo, attracting Belgian missionaries was a strategic and necessary move toward that end. After securing the coveted territory of the Congo, he indeed no longer needed the support of Protestant missionaries to influence British public opinion. His goal was now to replace these British as well as other non-Belgian Catholic missionaries altogether. Leopold used his diplomatic skills to convince the Vatican that only Belgian Catholic missionaries would ensure unity of vision in the colony. As a result, in 1886 Pope Leo XIII (1810-1903, r.1878-1903), initiator of the Catholic Social Teaching with his encyclical Rerum novarum of 1891, agreed

12 Patrick M. Boyle, "School Wars: Church, State, and the Death of the Congo," Journal of Modern African Studies 33, no. 3 (1995): 451-68, here 451. It is important to say a word on the colonies scolaires. Historian Léon de Saint Moulin discusses their foundation by a royal decree signed on July 12, 1890, a decree that placed under the tutelage of the state native children who were redeemed from Arab slave-owners as well as orphans and other abandoned children-whose parents were unable to meet the needs for education. See Léon de Saint Moulin, "Le Père Emile Van Hencxthoven, fondateur de la mission du Kwango," in Actes du colloque de Kimwenza, décembre 1993 (Kinshasa: Province d'Afrique Centrale, 1994), 12. 
that the territory of the Congo should be reserved for Belgian missionaries. Three years later, in 1889, the pope accordingly wrote to the superior general of the Scheut Fathers entrusting the mission of evangelizing the Congo to the newly founded order:

You are without ignoring, dear Sons, Our ardent desire to see the savage peoples of Africa abandon the darkness of error for the brilliance of the light of the Gospel and to exchange their dullest customs with politeness and Christian civilization. This change will have the effect of (1) exempting from the law of their caprices these tribes, which are reduced to the level of the animal state; and of (2) making them pass from the servitude of corruption to the glorious liberty of the children of God. ${ }^{13}$

This was the prevailing perception of the Africans in the Western collective consciousness: savage people living in the darkness of error, with dull and brutish cultures at the limit of the animal state. At the First Vatican Council in 1869-70, prelates evaluated the so-called curse of Ham and recognized the necessity to bring the light of Christ to the interior of Africa. The work of civilization thus necessitated an army of volunteer missionaries to respond to the call of the humanitarian crisis that besieged Africa. Indeed, the nineteenthcentury scramble for Africa took place within an atmosphere of Catholic missionary revival after the criticism of the eighteenth century had come to an end. Leopold had persuaded one of the major figures of the late nineteenthcentury revival of the Catholic missionary effort, the French cardinal Charles Lavigerie (1825-92) — founder of the Missionaries of Africa, commonly known as the White Fathers- White Fathers in the eastern part of the Congo State, and by 1888 he [Leopold] had succeeded in getting Flemish Scheut Fathers to take an interest in the Congo."14 As Lavigerie went across Europe in the same year preaching against the horrors of the Arab slave trade, Catholics in Belgium began to see acting in the CFS as a religious and humanitarian duty. This change of sentiment was attributed to Lavigerie's preaching, in which he likened Leopold to the sower of good seed and the Arab traders as the enemies who stole in and sowed tares. It was in this context that the king convened an anti-slavery conference in Brussels from November 18, 1889 to July 11890 , as a result of which the European powers not only assumed the moral duty to deal with the Arab slave trade but

13 Quoted in Jules Chômé, Indépendance congolaise: Pacifique conquête (Brussels: Editions de Remarques Congolaises, 1960), 5 (my translation).

14 Slade, "Catholics and Protestants in the Congo," 86. 
also accorded Leopold the right to exact a ten percent import duty hitherto forbidden by the free trade provision under the Berlin Act. The Belgian government also granted a loan of twenty-five million francs to the CFS, money that would further encourage Catholic missionary work in the Congo. ${ }^{15}$

However, in addition to involving Belgian Jesuits in the education and religious training of children redeemed from Arab slave-traders, Leopold also ordered the facilitation of the Jesuits' "settlement in every possible way. They were freely given large concessions of land, while their personnel and goods were often transported in the State steamers."16 The intertwining of the state and the Catholic Church was critical not only in the acquisition of "seed" converts to begin the mission with but also in the material assistance that the government provided to Catholic missionaries. ${ }^{17}$

Leopold explained his vision in an autographed note, sent on April 27, 1890, to the administrator of the CFS, Edmond van Eetvelde (1852-1925). In the note, he stated that he intended to establish three colonies of children (colonies d'enfants): "I am of the mindset to open three big colonies of children. One in the Upper Congo, toward Equator, uniquely set for military purposes. We will have the fathers to provide their religious and professional education. The other in Leopoldville $[\ldots]$ and the third one in Boma [...]." ${ }^{\prime 18}$ In reality, these camps were ghetto-like settlements in which native children were confined for the sake of education. When the Jesuits arrived in the Congo in 1893, there were already "eighty-five children whom the state had confiscated from the Arabized slave traders," on top of seventeen freed slaves, twelve workers, two carpenters, and two soldiers and their wives. ${ }^{19}$

Obviously, Leopold's intention was neither to create a native elite nor to educate free men by entrusting the colonies scolaires to the Jesuits for the education of children. On the contrary, the presence of the Jesuits was dictated by the desire to oust Protestantism, and at the same time, to educate and

15 Cline, "Church and Movement for Congo Reform," 47; Mudimbe, Idea of Africa, 46.

16 Slade, "Catholics and Protestants in the Congo," 86.

17 Historian Robert E. Smith demonstrates this close collaboration by relating a Jesuit mission superior's insistence that his subjects show great esteem to the state authority and underscore Belgium's civilizing mission in the Congo; see Robert E. Smith, "Here we are in full battle': Jesuits and Baptists in the Kwilu, Congo," American Baptist Quarterly 22, no. 2 (2003): 180-211. André Knockaert, a Jesuit priest, translated this article into French, which was then published in Telema (Lève-toi et Marche) 2-3, nos. 121-22 (2005): 114-42, here 119 .

18 Quoted in Fernand Mukoso Ng'Ekieb, Les origines et les débuts de la mission du Kwango (1879-1914) (Kinshasa: Facultés Catholiques de Kinshasa, 1993), 41 (my translation).

19 Van Reybrouck, Congo, 73. 
evangelize the natives. By the same token, these sons of Belgium would show more "nationalist" loyalty to the king's colonizing project, unlike their Protestant counterparts whose presence came to be perceived as undermining colonial unity. The king sought to raise and recruit eighty percent of these children for military purposes in the colony while the remaining twenty percent was left to serve the missionaries who in turn selected a few among them to become catechists. Thus, "the Jesuits fought for Jesus, but also for Leopold," as Belgian cultural historian David Van Reybrouck puts it.

Before examining the role of the catechists in the Jesuit and Protestant encounter in the Congo, it is important to pause here to consider the discernment process that led the Jesuits' to agree to take part in Leopold's project. The Jesuit decision to accept this mission did not come easily. On two occasions, the king had attempted to rally them to his colonial dream, but the Society of Jesus had declined both times. The first request was in 1879 . Later, in 1885 , the provincial superior of the Belgian Jesuits, Father Joseph van Reeth (1843-1923), explained to Father Anthony Anderledy (1819-92), then vicar general of the Society of Jesus during Superior General Peter Jan Beckx's (1795-1887, in office 1853-87) illness, of his decision to decline the king's offer. He argued that his province had already sent four men (two priests and two brothers) the previous year to open a mission in the Upper Zambezi. ${ }^{20} \mathrm{He}$ then summarized the province consultors' discernment in the following six reasons that motivated the province's refusal. ${ }^{21}$

The first of these was that the Jesuits believed that the king needed to go through the proper channels and talk to the Vatican hierarchy, since the distribution of missions was a prerogative of the Congregation de Propaganda de Fide, particularly as the latter had already assigned the evangelizing mission of the Congo to the White Fathers and the Holy Ghost Fathers. ${ }^{22}$ Second, the Belgian province did not have enough men for its own colleges in Belgium and Calcutta, and it had already made a major sacrifice in sending men to the Zambezi Mission in the previous year. Third, the experience of sending men to Guatemala in 1843 , in haste and with little preparation, had resulted in a major failure and there was no point repeating the same mistake. Fourth, there was an obvious conflict of interest between Catholic missionaries and the

$20 \quad$ Ng'Ekieb, Les origines et les débuts de la mission, 40.

21 Letter from the provincial of Belgium to the general, May 5, 1885; cited by Gérard Ciparisse, "Les tractations en vue de la création de la mission du Kwango: Le dossier de la Compagnie de Jésus (1879-1893)," Bulletin de l'Institut Historique Belge de Rome 42 (1972): 453-572, here 499-500. Quoted in Saint Moulin, "Le Père Emile Van Hencxthoven," 12nı. 
European adventurers attached to the colony. The notorious violence of the latter clashed with the goals of evangelization and moralization of the former. Fifth, Catholics in Belgium were suspicious of the king's colonial enterprise. And, finally, the expeditions sent to the Congo had not yet produced any significant results as compared with the investment made. In response, the general commended the provincial and the question was considered settled.

The king then tried a second time to encourage the Jesuits to take part in his colonial project. This request came after the king's diplomatic feat at the Berlin Conference in 1885 and despite the suspicions of Catholics in Belgium, who opposed the king's duplicitous policy of religious neutrality given the widespread belief that Leopold was simply playing politics to garner support from the Protestant churches working in the Congo. At Leopold's urging, in a sermon delivered in 1888, Lavigerie criticized Belgian Catholics for their lack of support for the king's African project. ${ }^{23}$ The king had considered Father Charles Croonenberghs (1843-99) to be a potential head of the Belgian Jesuit mission in the Congo because of his missionary experience in India and in the Zambezi. Three times, the secretary general of the CFs had invited Croonenberghs to speak about Africa. On the third occasion, Croonenberghs wrote to the Jesuit superior general, reporting: "Last month, a high-ranking official came to enquire whether the Society of Jesus would like to take part in the colonial work of the king in Africa. I have no doubt that the king himself had sent this man." ${ }^{24}$

Having learned of the proper channel to force Jesuits into obedience, Leopold sent an official request for Catholic missionaries to the Congregation de Propaganda de Fide, in which he explicitly referred to the Jesuits. As mentioned earlier, one of the reasons he needed Belgian missionaries was also to preempt the Portuguese from using their "right of patronage," which, according to the king, would undermine "the administrative unity of the Congo Free State [l'unitéadministrative dans le nouvel Etat]."25 Historian Yves Krumenacker remarks that conflicts did exist between the Congregation de Propaganda de Fide and Portugal on the question of prelates to be sent to Latin America, as well as on the control of the missions in its territories. If the king feared Catholic missionaries of other nationalities, then he had every reason to perceive Anglo-Saxon Protestant missionaries as a grave threat to his colonial project. After receiving his request, the Congregation de Propaganda de Fide contacted the Society's vicar general, Anderledy, who then relayed it to the provincial

\footnotetext{
23 Cline, "Church and Movement for Congo Reform," 46-47.

24 Ng'Ekieb, Les origines et les débuts de la mission, 39.

25 Krumenacker, "Le Xviı siècle."
} 
superior in Belgium. After examining whether there had been any changes in the situation since the first refusal in 1879 , the provincial decided to adopt a prudent attitude and wait, rather than getting drawn in by

some adventurous Europeans without resources, without morals, and without faith; having no respect for priests and neutralizing our influence on the natives by their words and examples; [a place] where it was likely that liberals and even Free-masons have a large share in the government and the administration. ${ }^{26}$

Although it would appear that the king took personal offense at this second refusal, he did not give up. In the aforementioned autographed letter to van Eetvelde, Leopold explained his plan to educate children rescued from the Arab slave-traders. The king's third request arrived in 1890, after the Brussels anti-slavery conference. He again recommended asking the Jesuits for their opinion about running these children's colonies. At the conference, the European powers allowed Leopold to levy a ten percent tax on commerce and agreed to involve Belgian Catholic missionaries in the education of children rescued from slavery. ${ }^{27}$ This time, the Jesuits accepted Leopold's invitation.

Several factors motivated this change in attitude. First, the fear that the Zambezi Mission would drain the province's personnel was no longer a concern since the mission had failed to expand. Second, many Jesuits in the province were beginning to feel unease with the order's repeated rejections of the king's invitations. Third, due to domestic politics in Belgium, in which liberals had succeeded in passing a law that established a state monopoly over the education of children, and in order to counter rising anticlericalism, the Jesuits felt that this was an opportune moment to secure the king's favors. A fourth reason could also be added, which is that the Scheut Fathers-who were still a young congregation - had eventually accepted a mission in the Congo in $1888 .{ }^{28}$ Realizing that the Jesuits were now inclined to agree to his request, the king sent an official letter to the provincial on May 12, 1890 and the Jesuits formally agreed to take part in the missionary work in the Congo. After three years spent making the necessary administrative and material preparations, the Jesuits finally sailed for the Congo to help implement Leopold's vision for the native Congolese.

\footnotetext{
$26 \quad$ Ng'Ekieb, Les origines et les débuts de la mission, 40.

27 Ibid., 41.

28 Ibid., 43 .
} 


\section{Perceptions, Prejudices, and Conflicts between Catholics and Protestants}

On their arrival, two major challenges awaited the Jesuits, namely a hostile physical environment and the presence of Protestant missionaries in the country. ${ }^{29}$ The Protestants viewed the king's insistence on using Belgian Catholic missionaries as a strategy designed to counteract the danger that Protestant missionaries would expose Leopold's exploitation of children and the atrocities visited on entire villages. Consequently, the Catholic presence came to be perceived by Protestants not only as a threat to their own presence in the Congo but also as being intimately associated with the king's cover-up strategy. In other words, the conflict between Protestants and Jesuits played out on two different levels. On the Protestant side, it was interpreted through the lens of political and economic interests, whereas, on the Catholic side, it was viewed more through an ideological or theological lens, in which the Catholics viewed the Protestants as "heretics."

Thus, the nature of the conflicts between Belgian Jesuit missionaries and the missionaries from the American Baptist Foreign Missionary Society (ABFMS) derived from the late nineteenth-century political zeitgeist. That is, the missionary scramble for the souls of the native Africans was symptomatic of the colonial scramble for Africa's lands and resources. ${ }^{30}$ This difficult situation endured throughout the first half of the twentieth century, reflecting the conflicting missionary interests and the differences between the two groups in understanding what role the church ought to play in the colonial mission of the state.

Arguably, philanthropy inspired the missionary zeal and the preaching of the Kingdom of God of the Protestants who went to the Congo in 1878. Historian Gösta Stenström notes that, sometime in May 1877, even before Stanley had reached the mouth of the Congo River in August of the same year, the British millionaire Robert Arthington (1823-1900) had contacted the Baptist Missionary Society (BMS) in London with an offer of one thousand pounds if the BMS immediately traveled to the populations lost in the darkness of the Congo in order to bring them the light of the blessed Gospel of Christ. ${ }^{31}$ When the first Protestant missionaries arrived in the Lower Congo in 1878 , they

29 Ibid.; see also Actes du colloque de Kimwenza, décembre 1993 (Kinshasa: Province d'Afrique Centrale, 1994).

$30 \quad$ Smith, "Here we are in full battle."

31 Gösta Stenström, The Brussels Archives, 1922-1968 (Uppsala: Swedish Institute of Mission Research, 2009), 66. 
encountered some vestiges of the early Jesuit evangelization of the sixteenth and seventeenth centuries. As one B MS missionary, William Holman Bentley (1855-1905), reports, the only things that he found in 1879 "were some ruins of an ancient cathedral, a crucifix among other fetishes of the king, and some confused memories of the previous teaching." ${ }^{32}$

While the Jesuits preached obedience to the civil authority, the Protestants took it upon themselves to promote freedom of religion and to protect the natives against the abuses of the state in the "Red Rubber" scandal. The rubber economic boom during the 1890 s led the Congo to become an important source of latex due to the high demand for car and bicycle tires. Given the king's ownership of the Congo and the state's rights on vacant lands, Congolese officials imposed a daily quota of rubber to be delivered to the state, creating a draconian system of forced labor that led to the deaths of hundreds of thousands of people while pushing millions of others to starvation. ${ }^{33}$ Protestant missionaries wrote numerous reports exposing the atrocities of the CFS:

From the Congo Mission Balolo, in the province of Equateur, and from Swedish and American missionaries in the Lower-Congo, reports were reaching us providing details about entire villages that were burnt to ashes when their inhabitants failed to meet the required quotas of their assigned work. In 1895, one report was sent by [George] Greenfell and in 1896 , another report by the Swedish missionary [E.V.] Sjöholm about maltreatment and atrocities imposed on the population. ${ }^{34}$

The Congolese colonial project was clearly conceptualized as an economic venture, unlike other colonies that were primarily framed as political enterprises. The consequence was the subjection of the Congolese people to extreme forms of forced labor that aimed at yielding the highest level of revenue for the state treasury and for Leopold's own personal gain.

When the Jesuits arrived in the Congo in 1893, the "Red Rubber" scandal was already in full-swing. The Jesuits were aware of the atrocities the CFS was committing against the natives, since this was one of the reasons they had refused to accept the king's original invitations in the first place. Yet they also enjoyed a position of privilege. They felt a need to cooperate with the administration,

\footnotetext{
32 Ibid., 62-63.

33 Jason K. Stearns, Dancing in the Glory of Monsters: The Collapse of the Congo and the Great War of Africa (New York: PublicAffairs, 2011), 23. Also, Saint Moulin, "Le Père Emile Van Hencxthoven," 30 .

34 Ibid., 75 .
} 
recognized the support they received, and shared the same goal as the state, namely to bring about civilization, although the two used different paths to reach that goal. ${ }^{35}$ Catholics used this privileged position within the colonial state system to intimidate or dislodge Protestants from villages that the latter had occupied. When the Congo was taken away from Leopold in 1908 and became a Belgian colony, Catholic missionaries remained silent about the colonial abuses of human rights. The Protestant missionaries interpreted this attitude as resulting from Catholic collaboration with the state.

Unlike the Catholics, Protestant missionaries were engaged in open campaigns to denounce the brutalities, atrocities, and violence perpetrated by colonial agents against the natives. Since most of them were foreigners, not Belgians, public opinion in Belgium grew increasingly hostile and the king saw in these erstwhile allies dangerous opponents to his vision and goals in Central Africa. As one scholar has argued,

It was when the Protestant missionaries began to take part in this Congo reform campaign that they came into direct conflict with the State authorities. Prudence had made them very slow to speak out in public criticism of the administrative methods of the Congo government, but once they had decided that this was the right course for them, their eyewitness atrocity stories figured largely in the literature of the campaign. The Catholic mission, on the other hand, pursued a policy of private representation rather than public criticism - their situation vis-à-vis the State was considerably more delicate than that of the Protestants in view of the subsidies and State help which they were receiving - and Leopold II did all that he could to use them in combating the propagandists who were attacking the State regime. ${ }^{36}$

Thus, for the king, there was an urgent need to replace the Protestants with Belgian Catholic missionaries whose abiding loyalty and patriotic sentiments would ensure, rather than undermine, the new state's administrative unity. Viewed within this context, the Catholic Church appears to have been an instrument of subjugation and as being complicit in the colonial state's policy of exploiting the native population. Nevertheless, each camp viewed and accused the other of betraying the very Gospel they claimed to bring to black Africans.

When Protestant missionaries at the General Congo Protestant Missionary Conference signed a memorandum in 1906 to be sent to all the Western powers

35 Smith, "Here we are in full battle," 120.

36 Slade, "Catholics and Protestants in the Congo," 87. 
they represented denouncing the colonial atrocities in the CFS, the Catholic Church was busy striking a concordat with the CFS. As a result of this agreement, two hundred hectares of land in free and perpetual concession were granted to the Catholic missions while a stipend would also be paid by the government to the Catholic missionaries. In return, the priests would preach loyalty to the state and work to produce docile citizens. ${ }^{37}$

For such advantages, the Protestants believed, the Catholics had turned a blind eye to the colonial plight of the Congolese natives. As Baptist missionary and historian Robert Smith notes, van Hencxthoven himself, the founder of the Jesuit mission in the Congo, downplayed the colonial brutalities in a letter dating from 1903 in which he wrote that what was happening in the Congo "happens everywhere in the world. The Congolese state is trying to eradicate those criminal ways of acting. The State is doing so much for the Blacks so as to make their rights respected." ${ }^{38}$ As a result, the Protestant missionaries felt discriminated against on many fronts, not least when it came to the ownership of land: whereas Jesuits ended up with 37,208 hectares of land by 1913 as a result of the 1906 concordat, the Protestants had only 209 hectares. The government also subsidized Catholic schools, which were nurseries for state agents and church converts, thus putting the Protestants at a considerable competitive disadvantage.

Schools had become centers for proselytization, and with the state support that they enjoyed, Catholic schools attracted more children than Protestant schools. This state of unfairness was exacerbated by the state's tendency to grant Jesuits a monopoly in running the schools founded on the concessions of multinational societies.

Hospitals also became centers for proselytization. The Jesuits were impressed by the success of the Protestants in the medical field, which was used to attract villagers into their religious turf. More than fifty villages had agreed to convert to Protestantism because of the influence exerted by the Vanga hospital, which had been created in 1913. As a result, the Jesuits went on to found a hospital in Djuma in 1919 in order to counter this Protestant influence. ${ }^{39}$ Yet Protestants developed grudges against the colonial administration regarding the healthcare service because they were given only one percent of the medical budget, even though they provided twenty percent of the 250 doctors working in the Congo at that time. ${ }^{40}$

\footnotetext{
37 Smith, "Here we are in full battle," 121.

38 Ibid., 118 .

39 Slade, "Catholics and Protestants in the Congo," 89.

$40 \quad$ Smith, "Here we are in full battle," 122.
} 
Thus, on the Catholic side, the founding of most Jesuit mission posts was dictated by the imperative of stopping the progress of Protestantism. To fend off the spread of Protestant heresy, the Jesuits adopted a strategy of first acquiring land, then training three catechists who were sent to occupy that land, and finally attracting more children into what were called farm-chapels, the missionary secondary posts established near one or several villages with the consent of the local chiefs. As an intermediary space between African societies and Western modernity, historian Victor Yves Mudimbe calls this hyphenated geography "the marginal space."41 Without severing themselves from their families and traditional environments, the children in the farm-chapels spent time in contact with a new way of thinking, being, and doing. They received catechism lessons and were also trained in farming and other subjects. Between 1895 and 1902, the Jesuits created more than 250 farm-chapels in the Congo. ${ }^{42}$ It would appear that the first person to use the term "farm-chapel" was Brother Gillet in a letter of June 1896, in which he explains:

The farm-chapels have for mission to disseminate all around, in a quick and easy manner, the practical knowledge of our religion. They are established with the authorization of the indigenous chiefs, on the outskirts of one or several villages. Each is comprised of a principal chimbeck [rudimentary housing], the place where all gather for spiritual exercises, next to which are built the housing structure for our young Christians. Thatched huts provide shelter for the livestock that we provided to them: chickens, pigs, goats, sheep, etc. Others contained work tools, harvests that were already gathered from cleared fields, and which were being used by our colonial authorities. To ensure a good use of these posts, we ourselves go often to visit them [...]. Besides, all the catechists from the farm-chapels return to Kisantu every Saturday. ${ }^{43}$

As Boyle observes, it is not without reason that Catholic missions, and more specifically the Jesuit ones, were criticized by the liberal Belgian government in a report in 1954 as comparable to the Paraguayan reductions:

Incontestably, on both the religious and political level, the missionary deals with people as a sovereign with his vassals; respected by some,

\footnotetext{
41 Mudimbe, Invention of Africa, 17.

42 Edouard de Moreau, Les missions belges de 1804-1930 (Brussels: Editions Jos. Vermant, 1933), 98-99.

43 Saint Moulin, "Le Père Emile Van Hencxthoven," 37-38.
} 
feared by others, but always obeyed, always making the rules in a way that brings to mind $[\ldots]$ his own narrow self-interest [rather] than the great interest of the population as a whole. ${ }^{44}$

At the level of perceptions, and given that Protestantism started with the rejection of the pope's authority as the vicar of Christ on earth, Jesuits viewed Protestants as heretics and enemies of the Catholic faith. It was written in the DNA of Protestantism, Jesuits believed, to undermine the principle of authority. This belief was so widespread among Catholics that one bishop, Jean Félix de Hemptinne (1876-1958), noted in 1950 that "the Protestants are gnawing at the principle of authority everywhere that they can undermine the authority of Belgians in the Congo. The big companies understand that Catholicism presents a stabilizing factor and for that reason, they have entrusted us the responsibility to educate." ${ }^{45}$ René Butaye (1858-1929), one of the earliest Jesuits to arrive in the Congo, put it this way: "The Jesuits had to act fast, to not allow the heresy to take root. They had to occupy the land [...] Fr. Allard was able to find a convenient spot in Kimbau [...] less than three miles away from Mwanza, the fortress of Protestantism." 46

As was briefly mentioned above, it would be wrong to assume that the relationships between the two confessions-Catholic and Protestant-were always tense, even though this was often the case. The Jesuits not only received some linguistic help from Protestant missionaries (for example, using a Kikongo dictionary written by Protestants who had been working in the region for more than fifteen years before the Jesuits arrived) but also benefited from medical services at the hand of Rev. Dr. Aaron Sims (d.1922), a Scottish missionary who was attached to the Livingstone Inland Mission (LIM) and one of the earliest Protestant missionaries to arrive in the Congo. Sims established the first church in Kinshasa for the American Baptist Missionary Union that later became the American Baptist Foreign Mission (ABFM). American pastor Thomas Moody paid an amicable visit to the Jesuit apostolic vicar of Kwango, Mgr. Stanislas De Vos (1859-1932), not only bringing some very kind words but also eggs, bananas, and some canned beans. De Vos wondered: "What do you think about these relationships between the Rev. Thomas Mondy [Moody] and the Apostolic Prefect of Kwango?"47 Another story related to the revolt

\footnotetext{
44 Boyle, "School Wars," 459.

45 Markowitz, quoted in Smith, "Here we are in full battle," 118.

46 Ibid.

47 Léon De Saint Moulin in Actes du colloque de Kimwenza, décembre 1993 (Kinshasa: Province d'Afrique Centrale, 1994), 18.
} 
of the Bapende from May to September 1931 shows there was some degree of mutual trust and cooperation between Catholics and Protestants. ${ }^{48}$ An article published in L'avenir colonial blamed the Bapende's revolt on the Protestant missionaries for having encouraged it. The Jesuit bishop, Sylvain van Hee (1875-1960), who was then apostolic vicar of Kwango, replied by defending the Protestants. He said he was not aware of any problem between the Catholics and the Protestant missionary Charles Smith, whom "I have the honor of knowing personally and whose perfect correction I highly appreciate in every aspect." 49

\section{The "Mission" Complex: Some Theological Considerations}

It is impossible to include everything that took place between the Jesuits and Protestants in the Congo in a summary account of several decades of early interactions. Further research could pay greater attention to conflict within the Jesuit mission itself, for instance, which was epitomized by the rocky relationship between van Hecxthoven and Liagre on the issue of the proliferation of farm-chapels at the expense of catechetical depth. Indeed, the concern with the numbers of converts is reminiscent of Saint Francis Xavier's (1506-52) policy in India of baptizing as many as possible and as fast as he could, leaving the work of deepening the faith for later. Likewise, churches and new posts proliferated in the Congo. Sacraments were administered in large numbers. And new recruits were added to farm-chapels. But what about the quality of the new converts' faith? These two men, van Hecxthoven and Liagre, disagreed so vehemently on the matter that they required arbitration from Brussels and Rome. Future analysis could also examine how the new Catholic social teaching informed the consciousness of the Jesuit missionaries to the Congo. This mission, in fact, opened only two years after the publication of Pope Leo XIII's encyclical Rerum novarum.

Given that Rerum novarum stressed the plight of workers in Europe against rapacious capitalist owners at a time of industrialization, what was it that

48 In La répression de la révolte des Pende du Kwango en 1931, Louis-François Vanderstraeten suggests that "Plusieurs facteurs expliquent cette révolte: l'administration particulièrement brutale du territoire de Kandale durant les dernières années; les prestations accrues exigées de la population par les compagnies H.C.B. et C.K. avec l'appui de l'Administration; les rivalités de clans dans deux chefferies voisines et l'hostilité de chefs coutumiers influents évincés par l'Administration; l'émergence d'une secte magico-religieuse qui fournit des cadres à la révolte et derrière laquelle se cachent les chefs coutumiers." Available online at http://www.i6doc.com/livre/?GCOI=28001100558340 (accessed May 23, 2017).

Smith "Here we are in full battle," 140. 
prevented the Jesuits in the Congo from implementing the spirit of human dignity and social justice in the Congo at a time when the Congolese population was being exploited by the CFS and allied companies? Was the denunciation of state brutalities simply overlooked by the Jesuits because the cause was championed by Protestants, the perceived enemies of the Catholic faith? While it is true that the Catholic Church grew in opposition to the spirit of the Enlightenment, which emphasized individual freedom and the capacity of human reason as if divorced from God and from God's law, the Jesuits harbored the suspicion that Protestantism was intimately related to the Enlightenment, given its insistence on the freedom of religion against the grasp of the Roman Catholic ecclesiastical empire. Unless the Jesuit attitude was dictated by nationalist sentiments that paralyzed commitment to social justice, one can conclude that the "erroneous" conception of civilization had colonized the intellectual structures put in place by these Jesuits to the point that they overlooked the moral abuses by the state that supported them. While Protestants and lay writers were quick to denounce colonial state abuses, some of the questions raised above regarding the Jesuit position remain largely unanswered and clearly call for further research.

\section{Bibliography}

Actes du colloque de Kimwenza, décembre 1993. Kinshasa: Province d'Afrique Centrale, 1994.

Boyle, Patrick M. "School Wars: Church, State, and the Death of the Congo." Journal of Modern African Studies 33, no. 3 (1995): 451-68.

Chômé, Jules. Indépendance congolaise: Pacifique conquête. Brussels: Editions de Remarques Congolaises, 1960.

Cline, Catherine Ann. "The Church and the Movement for Congo Reform." Church History: Studies in Christianity and Culture 32, no. 1 (1963): 46-56.

Conrad, Joseph. Heart of Darkness \& Selections from the Congo Diary. New York: Modern Library, 1999.

Dunn, Kevin C. Imagining the Congo: The International Relations of Identity. New York: Palgrave Macmillan, 2003.

Hochschild, Adam. King Leopold's Ghost: A Story of Greed, Terror, and Heroism in Colonial Africa. New York: First Mariner Book, 1999.

Krumenacker, Yves. "Le XviIIe siècle: Éveil protestant et déclin catholique ?" Cahiers d'études du religieux: Recherches interdisciplinaires 1 (2008). http://cerri.revues .org/242 (accessed May 22, 2017).

Markowitz, Marvin D. "The Missions and Political Development in the Congo." Africa: Journal of the International African Institute 40, no. 3 (1970): 234-47. 
Mayer, Ruth. Artificial Africas: Colonial Images in Times of Globalization. Hanover and London: University Press of New England, 2002.

Moreau, Edouard de. Les missions belges de 1804-1930. Brussels: Editions Jos. Vermant, 1933.

Mudimbe, V.Y. [Victor Yves]. The Idea of Africa. Bloomington: Indiana University Press, 1994.

Mudimbe, V.Y. The Invention of Africa: Gnosis, Philosophy, and the Order of Knowledge. Indianapolis: Indiana University Press, 1988.

Ng'Ekieb, Fernand Mukoso. Les origines et les débuts de la mission du Kwango (18791914). Kinshasa: Facultés Catholiques de Kinshasa, 1993.

Reardon, Ruth Slade. "Catholics and Protestants in the Congo." In Christianity in Tropical Africa, edited by C.G. [Christian Goncalves] Baëta, 83-100. Oxford: International African Institute and Oxford University Press, 1968.

Reybrouck, David Van. Congo: The Epic History of a People. New York: HarperCollins, 2014.

Smith, Robert E. "Here we are in full battle': Jesuits and Baptists in the Kwilu, Congo." American Baptist Quarterly 22, no. 2 (2003): 180-211.

Stearns, Jason K. Dancing in the Glory of Monsters: The Collapse of the Congo and the Great War of Africa. New York: PublicAffairs, 2011.

Stenström, Gösta. The Brussels Archives, 1922-1968. Uppsala: Swedish Institute of Mission Research, 2009. 


\title{
The Adulteresses Were Reformers: The Perception and Position of Women in the Religious Fight of Fernando Poo, 1843-190o
}

\author{
Jean Luc Enyegue, s.J.
}

The end of the Francisco Franco (1892-1975) regime in 1975 was marked by public protests against court decisions on adultery all over Spain. On October 10, 1976, the newspaper El país reported on a case in Zaragoza. ${ }^{1}$ Activists Anita Bennett and Jill Nichols reported another case in 1977, which led to one of the largest women's demonstrations in Spain's history. Women took over the streets in cities such as Madrid, Zaragoza, Mallorca, and Barcelona to ask for equal rights and emancipation. Their placards read: "We are all adulteresses." Almost a century earlier, Fernando Poo was still a Spanish possession. In 189o, Maria Smith, a Nigerian Protestant missionary, and other Protestant mothers led a protest against the political and religious establishment of Fernando Poo. ${ }^{3}$ The Spanish governor had refused to give Smith permission to build a school for girls. Fr. Emengol Coll, the Catholic apostolic prefect, supported the governor's decision on the grounds that such a school would work against Spain's national interests. ${ }^{4}$ Most of these women were tried, severely punished, and called "adulteresses."

The collusion between colonization and evangelization in Fernando Poo was especially harsh on women. Four years after Smith and the mothers' protest, in the Claretian mission of Fernando Poo, a woman was murdered. According to historian Jacint Creus, who is my main source on the incident, Father Andreu Puig-gros and Brother Antonio Artieda had ordered this "bad woman" to be beaten all night, with hands and feet tied, because of her "immorality." She was accused of inciting the children of her Protestant school to

1 "Absuelta una presunta adúltera en Zaragoza," El país, October 10, 1976; http://elpais.com/ diario/1976/10/10/ultima/213750002_850215.html (accessed June 25, 2017).

2 Anita Bennett and Jill Nichols, “Women's Movement in Spain," Off Our Backs 7 (October 1977): 10.

3 Today, Fernando Poo is part of the Republic of Equatorial Guinea.

4 ULTRAMAR, 5310, Expediente (EXP in the archives and in this text), Box 14, nos. 1-9, October 4, 189o. No biographical information is available on Maria Smith and many other missionaries mentioned in this essay. 
"debauchery," and of having sexual intercourse with her young pupils. None of the pupils involved in the intercourse was punished; but each of them was asked to give their schoolmistress fifty lashes, and the abuse continued throughout the entire night. ${ }^{5}$ Father Puig-gros and Brother Artieda were later arrested because of the incident, but Coll, as head of the Catholic Church in Fernando Poo, paid a fee to the leaders of the Bengal ethnic group to which the woman belonged and thus secured their release. Fernandian rulers themselves showed little concern for a girl whom they considered immoral, rebellious, and a subversive slave. ${ }^{6}$ However, the trial was the subject of a parliamentary debate in Madrid on May 29, $1895 .^{7}$

Creus claims to have consulted the Claretians' archives for the period between 1894 and 1902. But this woman, Ndjuke as he names her, remained nameless in those archives. The Claretians instead portrayed her as "a girl, a woman [...] 'Perverted,' 'repudiated,' 'pervertisseuse' [literally a pervertedmaker or spoiler], 'scandalous,' 'unfaithful,' 'corrupt,' 'ferocious,' 'dishonest,' 'bitch,' 'prostitute."' This essay will show that these so-called prostitutes or adulteresses were reformers in both the religious and political sense. On the one hand, they claimed their distinctive reformed faith as the reason for their fight for their civic and religious rights, and against a project of Catholic religious monopoly. On the other hand, they skillfully exploited loopholes in the colonial law to resist male dominance and successfully achieved substantial social reforms. What the archives of the Claretians say about Ndjuke indicates that the representation of women resisting male power in nineteenth-century Spain and its colonies was strikingly sexual, and demonizing. ${ }^{9}$ In Fernando Poo, the perception of women by religious males during the project of Catholicization gradually led to the exclusion of women from public space, and Ndjuke's murder was simply the highest point of a conflict that started with the arrival of the first Spanish expedition to the island in 1843 .

5 Creus wrote his dissertation on Catholic missions in Fernando Poo and its connection to colonialism. He published it in 1998. See: Jacint Creus, Action missionnaire en Guinée Equatoriale 1858-1910: Perplexités et nä̈vetés à l'aube de la colonisation (Paris: Université Paris VII, 1998).

6 Ibid., 529. "La femme ne leur importait que très peu; il s'agissait d'une esclave aux mœurs dissolues et rebelles à son propre chef Manuel Ukambala, dont on ne faisait aucun cas."

7 Ibid., $525 \mathrm{ff}$.

8 Ibid., 575 .

9 Ndjuke is the name Jacint Creus used. Few details are available about her. 


\section{Context of Women's Resistance to Missionaries in Fernando Poo}

There is a long history of African women resisting Christian missionaries and suffering severe punishments for their resistance. In seventeenth-century Ethiopia, for example, comparative linguist Wendy L. Belcher has shown that women presented the fiercest opposition to the Counter-Reformation led by the Jesuits. In Jesuit reports, these "sisters" were portrayed as "demons." ${ }^{10}$ In the Kongo Kingdom, historian Richard Gray alludes to the setback the Capuchins faced from educated women. ${ }^{11}$ In the late seventeenth and early eighteenth centuries, Kimpa Vita (1684-1706) led the Antonian Movement in its opposition to the Capuchins and paid for it with her own life. ${ }^{12}$ Likewise, in Fernando, during the nineteenth-century Spanish project of Catholicization, the Jesuits and the Claretians also faced opposition from Protestant women in a struggle that anticipated the women's march in the streets of post-Franco Spain. Initially converted by Baptist and Methodist missionaries, and mothers of Fernandian children, these women were the "heretics" the Jesuit archives left nameless but which their missionaries feared. They were the mothers whose children, including girls, the Jesuits struggled to bring to their school. And once the Jesuits left Fernando Poo, the women and the girls they educated became the opposition leaders against the Claretians in their efforts to Catholicize Fernando Poo. Key to their success, as we will see, was their high literacy rates and their mastery of modern Spanish law.

The Spanish colonial project in Fernando Poo was framed as an attempt to "Hispanize and Catholicize."13 To attain this goal, the court of Queen Isabella II (r.1833-68) organized and sponsored three Catholic missions and made the education of children in that Spanish possession a priority. Three centuries

10 Wendy Laura Belcher, "Sisters Debating the Jesuits: The Role of African Women in Defeating Portuguese Proto-colonialism in Seventeenth-Century Abyssinia," Northeast African Studies 13, no. 1 (2013): 121-66.

11 Richard Gray, “A Kongo Princess, the Kongo Ambassadors and the Papacy," Journal of Religion in Africa 29 (May 1999): 140-54, here 140. Quoting Mateo de Anguiano, 365-69.

12 Kimpa Vita was a sixteenth-century Congolese prophetess who started a religious movement aimed at reinterpreting Christianity and its key characters, including Jesus Christ, as of Congolese origin. She faced a trial in Kongo and was executed in 1706, at the age of twenty-two. See John K. Thornton, The Kongolese Saint Anthony: Dona Beatriz Kimpa Vita and the Antonian Movement, 1684-1706 (New York: Cambridge University Press, 1998).

13 Antonio Zarandona, "Proyecto de una misión a las islas españolas del Golfo de Guinea: Presentado en la Dirección de Ultramar Por A-Z, El 4 de Mayo de 1857," AнA. C 458, no. 8570009 . 
before, from 1645 to $1654,{ }^{14}$ Fernando Poo had received its first Christian mission when the Capuchins and the Discalced Carmelites attempted to evangelize in the region. ${ }^{15}$ This mission was part of numerous Catholic expeditions launched from Portugal, France, and Rome to save the souls of the large area from Sierra Leone to the Kingdom of Kongo, with São Tomé as the center of this Catholic project. ${ }^{16}$ The Carmelites' expedition also coincided with a new push from the Propaganda Fide to implement the Counter-Reformation in the Kongo. ${ }^{17}$ As far as women were concerned, on June 7,1607 , Jean de Brétigny (1556-1634), founder of many Carmelite communities in France, wrote to a Kongolese diplomatic delegation visiting the Spanish court: "God's providence," de Brétigny said, "has wished to send these Discalced Carmelite nuns in order to instruct 'little girls' [las donzellas]." Doing so, he believed, was "the best way to bring them to know and to love as their husband Jesus Christ and to offer him their virginity and service."18

However, there was a negative side to de Brétigny's plan in that it played on the dominant ideology concerning women's role in society in modern Europe, which nineteenth-century historiography later coined as "domesticity." In Spain, for instance, this ideology assessed the "Spanishness" of men according to their virility and nobility. Women's characters, in contrast, were portrayed as "the opposite sex, as a complement that was different."19 This ideology was also reinforced by the contradictions of Spanish modernity. In Spain, opponents of modernity feared that the erosion of the difference between men and women would destroy the foundation of society. Catholic anti-modernists embraced

14 Dolores Garcías Cantús, Fernando Poo: Una aventura colonial española en la África occidental; 1778-19oo (Barcelona: Ceibas, 2006), 43-44.

15 According to historian Keith J. Egan, the Carmelites began as a group of lay hermits on Mount Carmel around 1200. They became a mendicant order by 1247, were joined by a Second Order of women in 1452, contributed through Teresa of Jesus (1515-82) and John of the Cross (1542-91) classical texts to the Western mystical tradition, became two separate orders with the creation of the Discalced Carmelite Order in 1593, and gave the church one of its most popular women saints ever in Thérèse of Lisieux (d.1897); see Keith J. Egan, "Historia del Carmelo Español, Vol II-IV, by Balbino Velasco Bayón," Catholic Historical Review 81 (October 1995): 611-13.

16 Cf. Roger Onomo Etaba, Histoire de l'Eglise catholique du Cameroun, de Grégoire xv áJeanPaul II (1831-1991) (Paris: L'Harmattan, 2007).

17 Richard Gray, "The Kongo Kingdom and the Papacy: A Unique Conclave of Christianity in the Heart of 17th-Century Africa," History Today 47 (1997): 44-49.

18 Gray, "Kongo Princess," 151.

19 Susan Kirkpatrick, "Gender and Modernist Discourse: Emilia Pardo Barzán's Dulce Dueño," in Modernism and Its Margins, ed. Anthony L. Geist and José Monleón (New York: Garland Publishing, 1999), 117-39, here 118. 
the fin de siècle literature's opposition to women. According to comparative linguist Susan Kirkpatrick, that literature reduced women to sinfulness, sensuality, witchcraft, and paganism. ${ }^{20}$ Yet, on the other hand, de Brétigny also anticipated what would later become known in mission theory as "Women working for women." ${ }^{21}$ Both Catholic and Protestants missionaries addressed women's issues and wanted women to empower others in Fernando Poo.

By the time the Spanish Catholics returned to Fernando Poo in 1856, two things had become clear to them: Annobón, the island where the Carmelites had missioned in the seventeenth century, was still a predominantly Catholic island. And the Baptists and the Methodists had filled the vacuum the Catholic missionaries had left unattended. The success of Protestants in Fernando Poo, before the arrival of the Jesuits, is well documented. The diaries of Rev. Samuel Crowther (1807-91), the first African Anglican bishop, and his companion during the First Niger Expedition of 1841, Rev. James F. Schön, mention the success of the work Methodist and Baptist missionaries were doing in Fernando Poo. On October 28, 1841, Crowther wrote: "Many persons brought their children, to have their names written down, in order to [be] baptized. Some adults also applied for baptism."22 On October 31, 1841, Schön wrote in his journal: "There is a school here, of about forty children of the settlers, kept in the house of the Schoolmaster, a native of Cape Coast." ${ }^{23}$ On the same day, Schön is said to have baptized forty-four children; on November 7 , he baptized thirty more. Among those baptized "was a young woman, a native of the Island, living with a woman settler."24

The central ideas concerning the incoming Catholic enterprise in Fernando Poo in the nineteenth century were defined by Jerónimo Mariano Usera y Alarcón (1810-91). These ideas were pursued and implemented by three different Catholic missions: the expedition of Miguel Martínez Sanz (1856-57), the Jesuits (1858-72), and the Claretian fathers whom the Sisters of the Immaculate Conception accompanied from 1883. Usera y Alarcón was a secular cleric. Having spent some time catechizing two young black men in his parish of Chamberi, Madrid, he decided to launch a more ambitious project of

$20 \quad$ Ibid., 119.

21 Isabela Cabral Feliz de Souza, "The Educational Background of Women Working for Women in Rio de Janeiro," Convergence 31 (1998): 30-37.

22 Samuel Crowther and James F. Schön, Journals of the Rev. James Frederick Schön and Mr. Samuel Crowther Who, with the Sanction of Her Majesty's Government, Accompanied the Expedition up the Niger in 1841, in Behalf of the Church Missionary Society (London: Hatchard and Son, 1842), 340.

23 Ibid., 343-44.

24 Ibid., 341. 
evangelization in their place of origin, Fernando Poo. ${ }^{25} \mathrm{He}$ arrived in Fernando Poo in $1845,{ }^{26}$ eventually leaving for Cuba where he became bishop and founded the Congregation of the Sisters of Divine Love. Pope John Paul II (r.19782005) beatified him in June 1999.

Usera y Alarcón understood the Catholic mission in Fernando Poo in the mark of colonial assimilation and in continuity with slavery. In his memoir, he described his project as a civilized mission that required few expenses and was supposed to "submit people through charity". The missionaries would hold the Bible in one hand and the cross in the other to appease indigenous people in the name of civilization. ${ }^{27}$ This ideology was also supported by a racial component. The abolition of slavery, Usera y Alarcón believed, had deprived the Spanish colonies in the Caribbean of cheap labor. And since it had been proven that white men could not work effectively in such climatic conditions, it was necessary to keep the blacks as slaves. ${ }^{28}$

Usera y Alarcón's Memoirs of Fernando Poo refers to women solely while dealing with their sexual behavior. Women appear as victims of the institution of polygamy, which, for most Europeans, often connoted women's enslavement. He also shows that, in case of adultery, women were often more severely punished than men. ${ }^{29}$ In its seventeenth title, the Castilian law compendium of 1256 , Las siete partidas, ${ }^{30}$ already described adultery as "one of the greatest faults which men can commit [and] from which not only injury, but also dishonor, arises."31 Compared with Las siete partidas, the punishments for women found guilty of committing adultery, as feminist historian Marcel Bernos has shown, had become even more severe by the nineteenth century. One reason Bernos gives is that the prospect of a child born of an

25 San Cristóbal de la Habana o Zamora, "Jerónimo Mariano Usera Y Alarcón (1810-1891): Sacerdote y fundador de la congregación de las Hermanas del Amor de Dios; Positio sobre las virtudes y fama de santidad" (Congregación de las Causas de los Santos, 1995), i.

26 Claretianos Misioneros, ed., Cien años de evangelización en Guinea Ecuatorial, 1883-1983 (Barcelona: Claret, 1983), 13.

27 Jerónimo M. Usera y Alarcón, Memoria de la Isla de Fernando Poo (Madrid: T. Aguado, 1848), 68.

28 Ibid., 77 .

29 Ibid., 16.

30 The literal translation would be "Seven Games," but this does not give full account of the meaning. English commentary on this law compendium retained its Spanish title.

31 Robert I. Burns, ed., Las siete partidas: The Dead, the Criminal, and the Marginalized (Philadelphia: University of Pennsylvania Press, 2001), 5:1411. A man accused and convicted by a judge of having committed adultery faced the death penalty. A woman found in the same situation, in contrast, was publicly scourged, sent to a convent, and deprived of her dowry. 
adulterous relationship endangered peaceful succession in families and had greater potential of social conflict. ${ }^{32}$ Generally speaking, Bernos believes that the nineteenth century had simply made things worse for women's standing in society. ${ }^{33}$

Usera y Alarcón's project had a lasting impact on successive Spanish missions in Fernando Poo. As Martínez Sanz was preparing for his missionary expedition to Fernando Poo, he used Usera y Alarcón's memoirs as his main source of information about the Fernandians. ${ }^{34} \mathrm{He}$ also made sure that the forty members of his mission had knowledge of those memoirs. ${ }^{35}$ As such, Martínez's expedition did not depart from Usera y Alarcón's worldview. He described the Fernandian women as "slaves" of their husbands. His report also identified polygamy as a major obstacle for the success of any Christian mission in Fernando Poo. ${ }^{36}$ On the other hand, women were also part of Martínez's expedition both as wives and missionaries. ${ }^{37}$ For among the forty members who left Valencia and traveled to Fernando Poo in 1856 , five of them were priests; two were laywomen, the wife and mother of the carpenter; and twelve nuns. ${ }^{38}$ These women had been tasked with educating the girls and taking care of the sick. ${ }^{39}$ Martínez's own assessment of the mission, however, was that, with the exception of the carpenters, nobody else was to do anything substantial in Fernando Poo, not even the nuns, who were unable to educate the girls because they did not know the language. ${ }^{40}$ The question now was whether the arrival of the Jesuits with their missionary experience would succeed where Martínez and his friends had failed.

In June 1856, a royal decree founded the College of Loyola and Overseas Missions and entrusted the mission of Fernando Poo to the Society of Jesus. ${ }^{41}$

32 Marcel Bernos, Femmes et gens d'Église dans la France classique, XVII -XVIIIe siècle (Paris: Cerf, 2003), 256.

33 Ibid., 340.

34 Miguel Martínez y Sanz, Breves apuntes de la misión de Fernando Poo en el Golfo de Guinea (Madrid: Imprenta de Iñigo Reneses, 1859), 14.

35 Ibid., 92.

36 Ibid., 48.

37 He was the founder of a women's congregation, the Servants of Mary (Siervas de María).

38 But why would a man go to Fernando Poo not only with his wife but also his elderly mother? It was not a Catholic practice to have laymen missionaries going to mission accompanied by their wife. A possible reason is that some of these missionaries were paying their debt; they went to Fernando Poo as a punishment, as Sanz had suggested early in his text.

Martínez y Sanz, Breves apuntes de la Misión de Fernando Poo, 93.

$40 \quad$ Ibid., 102.

41 See my previous work on this mission: Jean Luc Enyegue, "The Jesuits in Fernando Po, 1858-1872: An Incomplete Mission," in Jesuits Survival and Restoration: A Global History, ed. Robert A. Maryks and Jonathan Wright (Leiden: Brill, 2015), 466-86. 
Fr. Antonio Zarandona (1804-84), procurator of the Jesuit missions in the court of Queen Isabella II, elaborated upon the mission project on May 4, $1857 .^{42}$ Born in Bilbao in 1804, he joined the Society at age twenty-four and did his regency in the Colegio de Nobles de Madrid (1831-33). He was ordained priest in 1834 in Madrid. The catalog of 1850 shows him as socius of Provincial Antonio Murrey, cumulatively serving as procurator for overseas missions. He held that function until 1882, two years before his death. ${ }^{43}$

Zarandona is the author of a book, La historia de la Compañía de Jesús:Desde su extinción hasta su restauración (The history of the Society of Jesus from its suppression to its restoration), the only edition of which was published under the direction of Ricardo Cappa (1800-97) in $1890 .{ }^{44}$ In the book, Zarandona gives a clear indication of his views on Protestants. The hatred of Sebastião Carvalho, marquis of Pombal (1699-1782), for the church and the Society, Zarandona argues, started from his time in Lutheran Germany. As a young diplomat there, Carvalho became familiar with the "doctrines of the century."45 Zarandona also accused Protestants, along with Jansenists and the philosophers, of disseminating Carvalho's pamphlets against the Jesuits. ${ }^{46}$

In the project Zarandona elaborated for Fernando Poo, he specifically described the scope of the Jesuit mission as being to "Hispanize and Catholicize" mostly by educating "young boys" and eventually the adults. ${ }^{47}$ The exclusive mention of the "boys" in his project might lead one to think that Zarandona and the Jesuits were less concerned about the situation of girls and women. The truth, however, is that the Jesuits in Fernando Poo were willing to extend their ministry to the girls, but they faced strong opposition from Fernandian mothers. Moreover, in their own words, they lacked the skills and personnel to deal with what they called "the other sex."

Fr. José Irísarri (1811-68) was appointed head of the mission. In his Memorias, Irísarri describes how Fernandian girls were inseparable from their mothers,

42 Antonio Zarandona, "Proyecto de una misión a las islas españolas del Golfo de Guinea: Presentado en la Dirección de Ultramar Por A-Z, El 4 de Mayo de 1857," Jesuit Archives in Alcalá de Henares (AHA). C 458, no. 8570009 .

43 For this account, I consulted the Jesuit catalogs of the Spanish province in Alcalá de Henares, from the restoration to 1900.

Antonio Zarandona, Historia de la extinción y restablecimiento de la Compañía de Jesús, ed. Ricardo Cappa, 3 vols. (Madrid: Luis Aguado, 1890), vol. 3 .

45 Ibid., 3:5.

46 Ibid., 3:26.

47 Zarandona, "Proyecto de una misión a las islas españolas del Golfo de Guinea: Presentado en la Dirección de Ultramar Por A-Z, El 4 de Mayo de 1857." 
which rendered their attempt to educate these girls almost impossible. ${ }^{48}$ Married men would also approach the fathers to complain about their wives' infidelities. Women, for their part, would complain about the indiscipline of the girls they were supposed to educate ${ }^{49}$ There is even a case of a catechumen widow woman. She had had two husbands and was about to marry a third man who, this time, was Catholic. ${ }^{50}$

The correspondence between Irísarri and his provincial portrays a permanent concern about the fate of young girls and the challenges the Jesuits faced to address issues related to women. ${ }^{51} \mathrm{~A}$ letter from the provincial of Toledo to Irísarri on July 13, 1865 made comments about the movements of the Jesuit personnel in Corisco, which was one of the islands included in the Fernando Poo mission. The provincial expressed his desire to have some "hermanas" (sisters) assisting in Corisco, as the fathers and sisters of the Holy Ghost (Spiritains) in Gabon did. Those sisters would take care of the education of children of the other sex (otro sexo). But the provincial was also reluctant to have sisters working with Jesuit missionaries because he wanted "to remain faithful to the Jesuit tradition." 52

In another letter, on September 11, 1865, the provincial emphasized the necessity of providing Christian education to girls. That kind of work would form these girls on tasks "proper for their sex." A Catholic woman, with proper manners and the ability to speak both English and Spanish was needed to carry out this task. The aim in forming these girls was to make them capable women, able to rule their home. ${ }^{53}$ As good mothers, they would breastfeed their children with the Catholic faith, so as to form a Catholic generation. ${ }^{54}$ But once again, the Jesuit tradition was perceived as an impediment. ${ }^{55}$

The reasoning of the Jesuits in Fernando Poo about women's ministries was that Jesuits' work with and for women seemed contrary to their tradition.

48 José Irísarri, Misión de Fernando Poo, 1859 (Barcelona: Ceibas, 1998). Especially, in his "Segunda memoria," December 19, 186o. Ref. AGA. A-G. C 780. E. 10.

49 Miquel Vilaró i Güell, El legado de los jesuitas en Guinea (Barcelona: Ceibas, 2010), 73.

$50 \quad$ Ibid., 77 .

51 These letters belonged to the Jesuit province of Toledo and are now being transferred to the AHA. Many of the letters are responses of the provincial of Toledo to Fr. Irísarri.

52 Archivo Provincial de Toledo, in AHA, C-67.

53 Ibid.

54 Ibid.

55 "Solo así es como se podría realizar un proyecto de tanta importancia; pues el pensar en monjas lo mira de mal ojo San Ignacio; y el admitirlas con los chicos nec nominetur; y el no enseñarles las labores propias de su sexo a la vez que se las instruye en la religión, es cosa de todo punto indispensable ut fructus noster maneat." 
That interpretation seems very conservative. It is true that the Jesuits, unlike other Catholic missionary orders such as the Dominicans and the Franciscans, the Spiritains or the Claretians, did not have a female branch that could have accompanied them in mission. ${ }^{56}$ Some historians have explained Ignatius of Loyola's $(c .1491-1556)$ reluctance concerning women's admittance to his order and Jesuits' ministries to them as proof of a misogynistic worldview. ${ }^{57}$ And to support this position, there is much evidence of the worldview of early modern Europe on women, which we can find in Ignatius's and other early Jesuits' writings. Women often appeared as weak, less mobile, and more fragile. ${ }^{58}$ The evil spirit in the Spiritual Exercises "conducts himself as a woman," a "weakling before a show of strength, and a tyrant if he has his will."59 However, an overlooked historical fact is that Ignatius actually admitted women to make their vows, although these women were forced out almost immediately. According to theologian Lisa Fullam, if Ignatius had come to see "the role of women as incompatible with, even contradictory to, the vocation of a member of the Society of Jesus," it was because Ignatius "believed that women of this time were incapable of promising the kind of availability for mission that lies at the heart of Jesuit calling." 60

As far as the practice in Fernando Poo was concerned, the Jesuits were able to baptize some girls. Their school also received Protestant children from countries such as Sierra Leone, Calabar, Lagos, and the Kongo. ${ }^{61}$ Because of their conservative interpretation of Ignatius's decision not to admit women to the order, the Jesuits in Fernando Poo, unlike the Spiritain fathers in Gabon, lacked

$5^{6} \quad$ The Ursulines Sisters were among the first to join the mission field with the Jesuits. On the Ursulines and gender in mission, see Alanna Catherine DeNapoli Morris, "Female Missionaries in The Jesuit Relations: A Study of the Creators of the Ursulines Seminary in Quebec" (мTs, Weston Jesuit School of Theology, 2005); Querciolo Mazzonis, Spirituality, Gender, and the Self in Renaissance Italy: Angela Merici and the Company of St. Ursula (1474-1540) (Washington, DC: Catholic University of America Press, 2007); Mazzonis, "The Impact of Renaissance Gender-Related Notions on the Female Experience of the Sacred: The Case of Angela Merici's Ursulines," in Gender, Catholicism, and Spirituality (New York: Palgrave, 2011), 51-67.

57 Jean Lacouture, Jesuits: A Multibiography (Washington, DC: Counterpoint, 1995), 135.

$5^{8}$ Alanna Catherine DeNapoli Morris, "Female Missionaries in the Jesuit Relations: A Study of the Creators of the Ursulines Seminary in Quebec" (MTS thesis, Weston Jesuit School of Theology, 2005).

59 Ignatius of Loyola, The Spiritual Exercises of St. Ignatius of Loyola (New York: Vintage, 2000), no. 325 .

6o Lisa Fullam, Juana, S.J.: The Past (and Future?) Status of Women in the Society of Jesus (St. Louis: Seminar on Jesuit Spirituality, 1999), 4.

61 Vilaró i Güell, El legado de los Jesuitas en Guinea, 108, 146. 
the female personnel they needed and never overcame the challenges girls and women posed to them. Thus it is no surprise that their desire to educate Fernandian girls never came to completion. Moreover, religious orders were suppressed both in Spain and overseas following the Spanish liberal revolution of 1868. Without resources for the mission, disappointed by the scarce results they harvested, and facing opposition from the natives with the support of Baptist and Methodist missionaries, ${ }^{62}$ the Jesuits left Fernando Poo in 1872 . They never returned, ${ }^{63}$ despite repeated requests from the colonial authorities. ${ }^{64}$

Fernandian Protestants represented a major obstacle for the success of the Jesuit mission in Fernando Poo. ${ }^{65}$ In a letter to Manuel Lozano, overseas minister, in 1864, Zarandona lamented the refusal of Fernandian families to send their children to the missionary school of Saint Isabel. These women believed that their children might be forced to convert to Catholicism. In response to that reluctance, the colonial government proposed constructing a public school for these "Spanish subjects born in error [i.e., Protestants]." Zarandona opposed this project, triggering a crisis that continued until the expulsion of the Jesuits in $1872 .{ }^{66}$ Similarly, in his response to the government justifying the refusal of the Jesuits to return to Fernando Poo, and the reasons why their mission there had failed, Zarandona stressed the fact that the heresy had "infested" the local population, rendering their work with children ineffective.

The departure of the Jesuits from Fernando Poo was just another step in the Catholic enterprise in Fernando Poo. As the Claretians took over the mission in $1883,{ }^{67}$ the Protestants' opposition, which had remained nameless, faceless, and genderless, now had names and female leaders whose impact definitively

62 Antonio Zarandona, A Manuel Lozano, Ministro de Ultramar, November 8, 1864. Box 58, no. 5640004: "La cuestión de la escuela civil se suscitó con motivo de que las familias de Santa Isabel, capital de la Isla, rehusaban mandar sus hijos a la escuela de los misioneros, temiendo que éstos los indujeron a abrazar la religión católica abjurando la secta metodista, que en aquella capital es la dominante; y a consecuencia de este retraimiento de los naturales, la autoridad de la Isla propuso al gobierno la creación de la referida escuela, por no dejar sin medio de educación a unos niños que si bien han nacido en el seno del error, son súbditos de España."

63 Ministro de Ultramar, Al Gobernador de Fernando Poo, January 1, 1871. Box 58, no. 8710003.

64 Correspondencia del or de abril de 1878. Box 58, no. 8780006; Correspondencia del 7 de abril de 1879. Ch. 58, no. 8790oo6; and A.Z. al Ministro de Ultramar, April 16, 1879. Box 58, no. 8920007 .

65 Enyegue, "Jesuits in Fernando Poo."

66 Antonio Zarandona, "Al Excmo. Sr. D. Manuel de Leijas Sorano, Ministro de Ultramar" (Box 58: 8640004, November 8, 1864).

67 Misioneros, Cien años de evangelización en Guinea Ecuatorial. 
affected the colonial educational polity in Fernando Poo. In fact, the Berlin Conference (1884-85) immediately followed the arrival of the Claretians in Fernando Poo (1883), in a context of a more aggressive Spanish commitment to the island. By 1884, the Spanish governor José Montes de Oca became more serious about implementing the 1865 decision prohibiting any non-Catholic presence in Fernando Poo. He explicitly singled out the Methodist presence on the island and the primary school they were running. 68 The Jesuit superior, Irísarri, seemed to have been in favor of this shift in strategy. In 1865, he directed the following words to the overseas minister: "In order to convert the Bubi to Catholicism and ensure their loyalty to Spain, there will need to be a system of colonial production serving Spanish companies, along with the limitation or progressive extinction of Anglo-Protestant presence, including that of Krumanes from British colonies." 69

The Claretians had been running the mission for seven years when, on February 15, 1890, the protest of Maria Smith and nineteen other Fernandian mothers took place. ${ }^{70}$ The protesters insisted that their "consciences" objected to their children being educated in schools that professed a creed different from theirs. And since "native" women in Santa Isabel could not "communicate to their children the light enkindled in their souls," because there was no center in Fernando Poo able to form these women to become schoolmistresses, they asked the governor to allow Smith to become a schoolmistress. They argued that Smith had not only been educated with the Catholic Sisters of the Immaculate Conception in Santa Isabel but that she had also previously studied in Lagos (with Protestants) and would thus be able to run a school for their children. ${ }^{71}$

Certain aspects of the mothers' demands require further clarification. First, they claimed that the Catholic faith was not their own, and that it was not proper for their children to be educated in Catholic schools. Consequently, despite the official expulsion of Protestant missionaries from Fernando Poo in 1865 when the Jesuits were still running the mission, ${ }^{72}$ it is clear that the Protestants had remained very active on the island. They even survived the expulsion of the Jesuits. Protestant women, especially, were involved in different activities, including education and running schools, caring for the sick, and direct evangelization.

\footnotetext{
68 Garcías Cantús, Fernando Poo, 554.

69 Irísarri, Misión de Fernando Poo, 1859, 11.

7 ULTRAMAR, 5310, EXP. 14, nos. 1-9, October 4, 1890.

71 ULTRAMAR, 5310, Exp. no. 3.

72 Irísarri, Misión de Fernando Poo, 1859, 11.
} 
In January 1873, for example, eight years after their official expulsion, Bella A. Nassau, a missionary woman, wrote to the sisters of the Auxiliary Society of Marion, Iowa. She asked for help for the Corisco mission: "Ten years ago [two years before the expulsion of the Jesuits], a girls' school was in successful existence on Corisco Island, as well as a boys' school and a church station. But for six years there has been no school at all for girls and women." ${ }^{73}$ She then asked for new missionaries to replace the missionaries who had died, and expressed the need to build houses in which "female missionaries may live, with the poor girls and women gathered around them." The letter finally goes on to say that there had been an increase in the number of African personnel in the missionary work. ${ }^{74}$

Moreover, these women were adept at interpreting and using Fernando Poo's colonial education laws to pursue their own interests. They carefully exploited legal loopholes to advance their own agenda. They started their request to the governor by complaining that they could not teach their children because they were not "certified" to teach in schools. Owning an official certificate was a key requirement of the 1890 laws in order to teach in a school. More specifically, they mention that there was "no [pedagogical] center" in Fernando Poo to train them, and therefore, help them receive those certificates. In other words, if a central requirement of the royal committee of 1890 was the creation of normal schools in colonies to train certified teachers, ${ }^{75}$ then the governor ought to implement the law by creating a normal school, or simply accept Smith's request. Furthermore, in making the case of Smith's singular credentials, probably unique on the island, these women are referring to another requirement that applied to Catholic missionaries from the time of the Jesuits. Being bilingual was an asset, not a hindrance, for the success of their mission. ${ }^{76}$ As far as the mothers were concerned, nobody was as bilingual, and therefore as well prepared, as Smith not only to teach but also to "rule" any school in Fernando Poo.

The governor ruled against Smith's request on March 12, 1890. However, in his ruling, he also suggested that, according to a royal decree of October 12, 1884, it was legally possible for Smith or any other person without a certificate to teach in Fernando Poo. The only obstacle to Smith, he said, was that

\footnotetext{
73 WWFW, January $1873,270$.

74 Ibid., 171. For Sir Matomba and the wife of Rev. Ibia were getting ready to do "the work of God."

75 ULTRAMAR, 5310, EXP. 7, nos. 1-4, March 17, 1890.

76 Zarandona, "Proyecto de una misión a las islas españolas del Golfo de Guinea. Presentado en la Dirección de Ultramar Por A-Z, El 4 de Mayo de 1857."
} 
she did not know the Spanish language. ${ }^{77}$ Not only was the governor's ruling contrary to laws organizing the missions in Fernando Poo; it also contradicted the same law upon which he based his own ruling. The decree of 1884 to which he was referring also allowed teaching to be conducted in a different language and religion, although it prohibited proselytism in schools. In addition, since the same governor had previously allowed a lay Methodist, named Barleycorn, who had no knowledge of the Spanish language, to teach in a school, ${ }^{78}$ the denial of the same right to the more talented Smith had more to do with her gender than anything else.

The ruling in favor of Barleycorn was an acknowledgment that the 1888 decree formalizing the Catholic monopoly on Fernando Poo did not explicitly prohibit the presence of another religion in the colony. In fact, there had always been Protestant children - though only a few of them-in the Jesuit schools in Fernando Poo. ${ }^{79}$ In addition, the Fernandians themselves had made little progress in learning Spanish. Therefore, Protestant schools teaching in English were legally allowed in Fernando Poo and its dependencies, on condition that the children learning in those schools should also learn to speak Spanish and become bilingual. ${ }^{80}$ Finally, in the Dictamen general (General declaration) of November 3, 1890, the government council recommended that, for the conversion of the Fernandians to have a lasting impact, the Claretian fathers had to effect conversion through the example of virtue rather than violence. The superiority of the Catholic faith would take care of itself. ${ }^{81}$

\section{Conclusion}

In Fernando Poo, early missionary writings had little or nothing to say about women. Until the 1870 s, the few references to the Fernandian women reduced them to their function in society as spouses (of men and of Christ) and "slaves" of their husbands and the patriarchal ruling elite. The first attempts to have

\footnotetext{
77 ULTRAMAR, 5310, EXP. 7 , no. 3.

78 ULTRAMAR, 5310, EXP. 14, nos. 1-9, October 4, 1890.

79 Irisarri, Misión de Fernando Poo, 1859.

80 Ibid.

81 "Para nuestros padres misioneros, será un día glorioso, aquel en que destruyan las sectas del protestantismo existentes en Fernando Poo, con el ejemplo de sus virtudes, con la persuasión y con el ejercicio de la caridad que tanta influencia tiene sobre todos los espíritus, al paso que, empleando la violencia no se conseguirá otra cosa que irritar los ánimos, aumentar el número de los desafectos, y hacer infructuoso el trabajo de su conversión en que estamos comprometidos."
} 
women actively participate in missionary work took place in the second half of the nineteenth century with the wives of Protestant missionaries, and the fourteen women who were part of Martínez Sanz's expedition. For reasons related to the nature of their institution, but which had more to do with the particular conservative context of the Society in Spain after the restoration, the Jesuits were unable to provide effective education for girls. This situation became unsustainable with the arrival of the Claretians. Their clash with educated Fernandian women involved the excessive use of force that led to the torture of Ndjuke, demonizing her, destroying her character, and ultimately resulting in her death.

Portrayed as adulteresses by their male opponents, women in Fernando Poo were true reformers, pioneers of the emancipation of women a century before Spanish women descended on the streets of Madrid, Zaragoza, and Barcelona. They skillfully reacted to the changing power dynamics in Fernando Poo in different ways. They used civil protests by refusing to send their children to Catholic schools and demonstrated against government policies. Fernandian mothers outsmarted the governor and the apostolic prefect in the interpretation of Spanish law, and so contributed to substantial changes in education policies in Fernando Poo.

The effectiveness of the women's strategy was reflected in the resolutions of the Dictamen. These resolutions empowered Fernandian women, granting them the same rights as men (including equal pay) as far as education was concerned. In fostering bilingualism, even for a transitional period, women leaders whose lingua franca was Pidgin English were further empowered. Their role in society as mothers and their intellectual abilities gave them greater control over the education of their children. Because of these women, there was no longer any need to have a state certificate to become a teacher or schoolmistress in Fernando Poo. By October 27, 1890, primary education had become mandatory (and free at the district level) for both boys and girls in the Philippines, and thus in Fernando Poo. ${ }^{82}$ The same decree of October 27, 1890 also said that the instruction could be both public and domestic, ${ }^{83}$ depending on what the parents had chosen for their children. ${ }^{84}$ Domestic education in which women played a central role was recognized. And the Catholic monopoly that was at the core of the entire colonial project never became an absolute reality,

\footnotetext{
82 ULTRAMAR 5310,19 , nos. $1-5$.

83 In this polygamist context, women often have their own house (cf. Edmundo Sepa Bonaba, España en la Isla de Fernando Po [1843-1968]: Colonización y fragmentación de la sociedad Bubi [Barcelona: Icaria, 2011], 92-93).

84 Ibid.
} 
at least until after the 19oos when the government introduced lethal force and Fernando Poo had officially become a Catholic state.$^{85}$ Liberal education policies promoted by laymen and women had won the school debate in Fernando Po, at least during the period examined in this essay. ${ }^{86}$

\section{Bibliography}

\section{Archives}

AGA: Archivo General de la Administración.

AHA: Archivo Histórico de la Provincia de Castilla (y Toledo) de la Compañía de Jesús en Alcalá de Henares.

AHL: Archivo Histórico de la Compañía de Jesús en Loyola.

AREs: Archivo Nacional de España.

Digital Collections of Yale University, Periodicals:

Home of Foreign Record of Protestant Missions (HFR), Years 1851-90.

Women Working for Women (wWFW), Years 1872-90.

http://web.library.yale.edu/divinity/day-missions-collection-periodicals-listing (accessed June 25, 2017).

\section{Primary Sources}

Crowther, Samuel, and James F. Schön. Journals of the Rev. James Frederick Schön and Mr. Samuel Crowther Who, with the Sanction of Her Majesty's Government, Accompanied the Expedition up the Niger in 1841, in Behalf of the Church Missionary Society. London: Hatchard and Son, 1842.

Irísarri, José. Misión de Fernando Poo, 1859. Barcelona: Ceibas, 1998.

85 Robert J. Barro and Rachel M. McCleary, “Which Countries Have State Religions?" Quarterly Journal of Economics 120, no. 4 (November 2005): 1331-70, here 1336.

86 The outcome of this debate over education also sheds new light on the murder of Ndjuke. She was the product of the education debate that started with the Jesuits in 1864. The governor had aimed to create a public school that would limit Jesuit control over education. But its success almost brought down the colonial project altogether, as it failed to Catholicize Fernando Poo through the means of education, an area where Protestants seemed to have a stronger hand. By 1894, the year she was murdered, Ndjuke had become a schoolmistress and a leader. The accusation of sexual misbehavior was the manifestation of an increased sense of unease among the male elite of Fernando Poo, both secular and religious. Their alliance around Ndjuke's corpse can therefore be seen as an attempt by men to reaffirm their power over women by all means. 
Martínez y Sanz, Miguel. Breves apuntes de la misión de Fernando Poo en el Golfo de Guinea. Madrid: Imprenta de Iñigo Reneses, 1859.

Misioneros, Claretianos, ed. Cien años de evangelización en Guinea Ecuatorial, 1883-1983. Barcelona: Claret, 1983 .

Usera y Alarcón, Jerónimo M. Memoria de la Isla de Fernando Poo. Madrid: T. Aguado, 1848.

Zarandona, Antonio. “Al Excmo. Sr. D. Manuel de Leijas Sorano, Ministro de Ultramar." Ch. 58: 8640004, November 8, 1864 .

Zarandona, Antonio. "Proyecto de una misión a las islas españolas del Golfo de Guinea: Presentado en la Dirección de Ultramar Por A-Z, El 4 de Mayo de 1857," n.d. AHA. C 458 , n. 8570009 .

\section{Secondary Sources}

Barro, Robert J., and Rachel M. McCleary. "Which Countries Have State Religions?" Quarterly Journal of Economics 120, no. 4 (November 2005): 1331-70.

Bennett, Anita, and Jill Nichols. “Women's Movement in Spain.” Off Our Backs 7 (October 1977): 10.

Bernos, Marcel. Femmes et gens d'Église dans la France classique, XVIIU-XVIIIe siècle. Paris: Cerf, 2003.

Burns, Robert I., ed. Las siete partidas: The Dead, the Criminal, and the Marginalized. Vol. 5. 7 Vols. Philadelphia: University of Pennsylvania Press, 2001.

Cabral Feliz de Souza, Isabela. "The Educational Background of Women Working for Women in Rio de Janeiro." Convergence 31 (1998): 30-37.

Creus, Jacint. Action missionnaire en Guinée Equatoriale 1858-1910: Perplexités et naïvetés à l'aube de la colonisation. Paris: Université Paris VII, 1998.

DeNapoli Morris, Alanna Catherine. "Female Missionaries in the Jesuit Relations: A Study of the Creators of the Ursulines Seminary in Quebec." MTs thesis, Weston Jesuit School of Theology, 2005.

Egan, Keith J. “Historia del Carmelo Español, Vol II-IV, by Balbino Velasco Bayón.” Catholic Historical Review 81 (1995): 611-13.

Enyegue, Jean Luc. “The Jesuits in Fernando Po, 1858-1872: An Incomplete Mission.” In Jesuits' Survival and Restoration: A Global History, edited by Robert A. Maryks and Jonathan Wright, 466-86. Leiden: Brill, 2015.

Fullam, Lisa. Juana, S.J.: The Past (and Future?) Status of Women in the Society of Jesus. St. Louis: Seminar on Jesuit Spirituality, 1999.

Garcías Cantús, Dolores. Fernando Poo: Una aventura colonial española en la África occidental; 1778-19oo. Barcelona: Ceibas, 2006.

Gray, Richard. "The Kongo Kingdom and the Papacy A Unique Conclave of Christianity in the Heart of 17th-Century Africa." History Today 47, no. 1 (1997): 44-49. 
Gray, Richard. "A Kongo Princess, the Kongo Ambassadors and the Papacy." Journal of Religion in Africa 29 (May 1999): 140-54.

Irísarri, José. Misión de Fernando Poo, 1859. Barcelona: Ceibas, 1998.

Kirkpatrick, Susan. "Gender and Modernist Discourse: Emilia Pardo Barzán's Dulce Dueño.” In Modernism and Its Margins, ed. Anthony L Geist and José Monleón, 117-39. New York and London: Garland Publishing, 1999.

Lacouture, Jean. Jesuits: A Multibiography. Washington, DC: Counterpoint, 1995.

Misioneros, Claretianos, ed. Cien años de evangelización en Guinea Ecuatorial, 1883-1983. Barcelona: Claret, 1983 .

Onomo Etaba, Roger. Histoire de l'Eglise catholique du Cameroun, de Grégoire XV áJeanPaul II (1831-1991). Paris: L'Harmattan, 2007.

Sepa Bonaba, Edmundo. España en la Isla de Fernando Po (1843-1968): Colonización y fragmentación de la sociedad Bubi. Barcelona: Icaria, 2011.

Vilaró i Güell, Miquel. El legado de los jesuitas en Guinea. Barcelona: Ceibas, 2010.

Zamora, San Cristóbal de la Habana o. "Jerónimo Mariano Usera Y Alarcón (1810-1891): Sacerdote y fundador de la congregación de las Hermanas del Amor de Dios; Positio sobre las virtudes y fama de santidad." Congregación de las Causas de los Santos, 1995 .

Zarandona, Antonio. “Al Excmo. Sr. D. Manuel de Leijas Sorano, Ministro de Ultramar." Ch. 58: 8640004, November 8, 1864 .

Zarandona, Antonio. Historia de la extinción y restablecimiento de la Compañía de Jesús. Edited by Ricardo Cappa. Vol. 3. 3 Vols. Madrid: Luis Aguado, 1890.

Zarandona, Antonio. "Proyecto de una misión a las islas españolas del Golfo de Guinea. Presentado en la Dirección de Ultramar Por A-Z, El 4 de Mayo de 1857," n.d. AHA. C 458 , no. 8570009 . 


\section{Index}

Abassia 12n8. See also Ethiopia

ABFMs. See American Baptist Foreign

Missionary Society

ABFM. See American Baptist Foreign

Mission

abortion 105

abuna 37

Abyssinia 11-12, 34, 37, 40-57, 217

Adriaan, Hendrik 85

adulteresses (women reformers) 215-17, 219, 221, 223, 225, 227, 229

Adventist 114, 123, 146

Aedesius $35 \mathrm{n} 3$

Aethiopia 42, 49

Aethiopians 40

Aethiopic 48n39

Affaire des placards 4

Afonso, Mendes 39

African religious wildness 13

Africans 17, 19, 22-23, 59-60, 68-71, 73, 75,

$77,115,119,122,133-34,136,138-40,142$,

$147,152,156,159-63,166,195,199,201$, 206, 208

Afrikaans 106n65

African National Congress (ANC) 99

Afrikaners 92

agriculture 19, 34, 115, 127, 156, 175

AHA See Archivo Histórico de la Provincia de Castilla (y Toledo) de la Compañía de Jesús en Alcalá de Henares

Ahmad Gran 37

Albigensian heresy 9

Alcalá 4-6, 222

Alexandria, See of $\quad 16,35$

Algeria 16,6o

Algiers 16, 44

Ali Pasha $\quad 46,49,5^{1}$

Allan, Thomas 110n2, 112

Allard (Jesuit priest in Congo) 211

alliances $36-37,41,147,230 n 86$

alligators 69

Almeida, Manoel de $\quad 12,40$

History of Ethiopia 40

alumbrado 4

Álvares, Francisco $\quad 37,40$
Ama Roma 92

Ambaca 64

Ambacans 69

Ambahivoraka 188

ambassador $35 \mathrm{n} 3,36,40,85,178$

Ambositra, region $\quad 185^{-86}$

Amda Siyon 35

American Baptist Foreign Mission (ABFM)

211

American Baptist Foreign Missionary Society

$$
\text { (ABFMS) } 206
$$

Americas $13,60,76$

Amharic 46, 48

Amphilla Bay 54

amulets 179

anarchy 40

ANC. See African National Congress

ancestors 173

ancestral idols $\quad 23,189$

ancestral spirits 68

Anderledy, Anthony 203-4

Anderson, William Harrison $\quad$ 14n17, 6on2, $114,123,129-30$

Andriambelo, pastor 179

angel 165

Anglicans $\quad 23-24,89,91,98,101-2,100,105$, $114,125,127,142,144,146,156,183-84$, 187,219

Anglicanism 16, 92

Anglo-Protestant missionaries $\quad 52,204,226$

Angola 12, 18, 63-64, 66, 69n38, 7on38, 73-74, 111-12, 116, 137

Anguiano, Mateo de $217 \mathrm{n} 11$

Ankers, pastor 188

Annales de l'Association de la propagation de la foi 60

Annobón, island 219

Antananarivo, Madagascar $\quad 172-73,175^{-77}$, 179-8o, 182-83, 185-86, 188-89, 191-93

anticlericalism 205

anti-conscription 97

Antioch 35

Antonian Movement 217. See also adulteresses

Antwerp 9, 200 
apartheid $\quad 94-98,100-1$

Apolo Kagwa, chief 17

apostasy 7

apostolate $\quad 1,92,104,187$

Apostolic $\quad 6,7,15,18,89,127,139,152,174-75$,

$180-81,185-86,211-12,215,229$

Arab 197, 200-2, 205

Arabia $\quad 35,38$

Arabic 38,92

Arabized 202

Archivo Histórico de la Provincia de Castilla

$$
\text { (АHA) 217, 222-23 }
$$

Armenian 36

armies 46, 133, 142

Arnot, Frederick Stanley 113

Arthington, Robert 206

Artieda, Antonio $\quad 215^{-16}$

artisans $36,162-63,172$

artists $49 \mathrm{n} 42,172$

arts $45,48,5^{6}$

Asia 13, 15, 6o, 88, 16on39

assegaid 142

assimilation $77,154,220$

astronomical 85

Atlantic Ocean 85

atrocities, colonial $\quad 17,99,145,195 \mathrm{n} 1,199$, 206-9

Augsburg, Peace of 4

Australia $\quad 96 \mathrm{n} 40$

Auxiliary Society Sisters $\quad 227$

Axum $\quad 35^{-3} 36,38$

Axumite 35

Bakwains, people 71

Bakwena, people 75

Baldwin, Arthur 114

Balkans 38

Balolo, Congo mission 207. See also Congo mission

Bamanguato/Bamangwato 133, 157

Bangwato, people 19. See also Mangwato

Bangweulu lake $\quad 76$

Bapende, people 212

baptism 22, 75, 77, 116, 126, 159, 173, 178-79, 192,219

Baptist Missionary Society (BMS) 14, 46, 206-7

Baptists 14, 46, 194, 102, 105, 202, 206, 209, $211,217,219,225$ barbarism $\quad 61,72,85,87,139,140,195$

Barcelona, Spain $\quad 215,229$

Barleycorn, lay Methodist 2

Baron, island $176 \mathrm{n} 27$

Barotse, people 19

Barotseland 113, 117, 119

Barreto, João Nunes 37

Barthélemy, Marcus 22, 144

Bartoli, Daniello 7, 9

History of the Life and Institute... $\quad 7 \mathrm{n} 18$

Basel, Switzerland 8

Basutoland 19, 89

Batz, Gaston de 188

Baur, John 14, 73 2000 Years of Christianity in Africa 11n1, 14n16, 73n78, 111n5

beads 135,158

Bechuana/Bechwana, people $19,71,156$

Bechuanaland 135, 137

Beckx, Peter Jan $\quad 89,117,203$

beef 140

beer $140,159,166$

Beetham, Thomas Allan $\quad$ 112, 124, 129

beheadings $54 \mathrm{n} 57,174$

Belgians 17, 25, 117, 158, 194-96, 199-206, 208, 210, 211

Belgium 197, 199, 201-5, 208

Belgravia, Johannesburg 98

Bemba tribes 118,162

Benedictines 6,112

Bengal 216

Bennett, Anita 215

Berghegge, Francis $\quad$ 159, 166-67

Berlin, Act of $1885 \quad$ 199, 202

Berlin Conference $\quad$ 134, 195-99, 204, 226. See also Leopold II and Congo

Berman, Edward 120

Bermudez, João 37

Bernos, Marcel 220-21

Betsileo, people 187

Betsimisaraka 175

Bevan, Thomas 172

BFBS. See British and Foreign Bible Society

Bhebe, Ngwabi

Christianity and Traditional Religion in

Western Zimbabwe 1859-1923 133n1o, 138n41, 138n45, 144n79, 146n95

Bible $16,48,49,52,69-72,99,129,141$, $165-66,173,177,179,182,220$ 
Bick, Charles 23, 91-92

Biko, Steve 95

Bilbao, Spain 222

bilingualism 227-29

biology $5^{2}$

Birkinshaw, Philip 74

bishops, Catholic and Protestant 11, 23, 24, 26, 35, 35n $3,48,85 \mathrm{n} 6,89,91,94-95$, 100, $105,110,142,146,151 \mathrm{n} 3,153 \mathrm{n} 8,184-85$, 198, 211-12, 219-20

Black Consciousness 95

Blake, Robert 136

A History of Rhodesia 134n14, 136n28, 140n $56,1416_{3}$

Bloemfontein, diocese of $\quad 142,146$ BMs. See Baptist Missionary Society Bobadilla, Nicolás 4

Bobiller, Joseph $\quad$ 175n21

Boer. See also South Africa, Zimbabwe, and Zambia

armies 133

people 91,141

republics 89

rule $84 \mathrm{n} 2$

Boer War 91-92

Bolink, Peter 121-22, 165

Boma, Congo 202

Bombay Engineer Corps 49

Bombay, India $151 n 3$

Bompard, Maurice $\quad 186$

Bonaparte, Napoleon 15

Borja, Francisco de 5

Boston 38, 72

botany $5^{2}$

Botswana 19, 75, 84, 89-90, 98, 135, 137, 140, $15^{2}, 15^{8}$

Boudou, Adrien $\quad 171 n 2,174-76,178-82$, 184-87, 190, 192

Bourbon, Madagascar 174

Boyle, Patrick 200, 210, 211n 44

boys, education of $25,35,89,91,156,222$, 227,229

brandy 158

Brésillac, Melchior de Marion 15

Brest, France 85

Brétigny, Jean de 218-19

British and Foreign Bible Society (BFBS) 14

British Congregationalists 19

British Protestants 19o. See also Anglicans
British South Africa Company (BSAC) 22, $115,119,135,141-42,144-48$

Britons 34

Bruce, James of Kinnaird $43-46,50,52$, $55^{-56}$

Travels 44

Brussels, Belgium 25, 196, 201, 205, 212

Brutail, Martin 188

brutalities, colonial $195 \mathrm{n} 1,208-9,213$. See also atrocities

BSAC. See British South Africa Company

Bubi, people 226

Buckenham, Henry 114

Buddu, province 17

Buganda kingdom 17n3o. See also Uganda

Bulawayo, Zimbabwe $\quad 22,90,118,124 n 46,144$

Butaye, René 211

Cahenda, missionary station 64

Cairo, Egypt 42

Calabar, Nigeria 224

Calcutta, India 203

calico, textile $\quad 15^{8}$

Calvin, John $4,7,70$

Calvinist $\quad 12,84,95,153$

Cameron, Charles 53

Campan, Albert $\quad 181$

Canada 96n40, 98

Canary Islands 85

Canisius, Peter $\quad 4,7$

cannibals 160

Canterbury, archbishops of $\quad 76 \mathrm{n} 72$

Cape Coast, Ghana 219

Cape Colony $19,60,89$

Cape of Good Hope $\quad 12,36,38,68,84-89$, 99, 151

Cape Town 91, 97, 99, 151

Cappa, Ricardo 222

captives 40,54

captivity 38

Capuchins $11,26,64,112,165,217-18$

Carafa, Pietro 8

caravan 26, 33

cardinal $8,12,17,201$

Cardoso, Mateus $69 n 38$

Carey, William 14

Caribbean 220

Carmelites 218-19

Carmody, Brendan $\quad 22,116,124 n 46,158 n 27$ 
Carnegie, David 140

carpenters 202, 221

carpentry $114,156,162$

Carthage 49

Carthaginians 40

cartography 43

Carvalho, José Vaz de $70 n_{3} 8$

Carvalho, Sebastião $\quad 222$

cashews 63

caste $184 \mathrm{n}_{55}, 192$

Castilian 5,220

catechetical 118, 124, 212

catechism $7,48,69,175,210$

catechists $125,203,210$

catechumen 223

cathedrals $91,112,185,188,200,207$

Catholic Emancipation $\quad 85 \mathrm{n} 6,89$

Catholicism $12,26,37,39,43,61,85,89,92$, $111-12,125,127,153,155^{-56}, 163,176,183$, 190, 192, 211, 224-26

Catholicity $99,102,160$

Catholicization 216-17

Catholics $\quad 13-18,22,24-26,60-61,87-88$, 91-94, 98, 100-2, 105, 120, 122, 126-29, 153-54, 157-58, 16o-61, 163, 165-66, 174, $176-77,179,181-83,185,187-89,191-92$, 197, 201-4, 206, 208-9, 211-12, 219

Caussèque, Pierre $\quad 183,185,188$

Cazet, Jean $\quad 185^{-86,188-90}$

Cedara, South Africa 104

celebrations $173,178,180,185,188$

celibacy $\quad 165$

Center for Ignatian Spirituality (CIS) 102, 104, 106

centralization $124 \mathrm{n} 46$

ceremonies $91,127,159,179-80$. See also rites and rituals

CFS. See Congo Free state (CFS)

Chamberi, parish 219

chapels $25,68,117,210,212$

chaplaincies $\quad 22,97,101,104,107$

chaplains $\quad 22,94,96,97-99,101-2,110,141$, 144

Chaplets 88

charity $48,65,88,188,220$

Chartered Company 147. See also Rhodesia

Chatteris, Chris 100

Chemnitz, Martin

Theologiae jesuitarum praecipua capita 8
Chicago Congress 11

chickens 210

chiefdoms $\quad 117-18,133,136$. See also kraals

chiefs $17,20-21,39,133-37,140-41,143,145$, 157-58, 210. See also specific chiefs

Chikane, Frank 98, 107

Chikuni mission 118, 124-25

Chikuni Mission (Moreau) 19n37, 20n41, 21n $44,22 n_{51}$

children $22,25,100,125,127,156-58,162,175$, 177-78, 182-85, 200-3, 205-6, 209-10, $215,217,219,223-29$

chimbeck 210

China 62

Chipempi mission $\quad 125$

Chirenje, Jackson 134n19, 137n36, 137n38, 140060

Chishawasha valley and mission $\quad 146,157$, 159

Chitambo, Rhodesia 114

Chitonga, language 129

Choctaw language $\quad 71-72$

Chômé, Jules $201 n 13$

Christendom 117

Christianity $11-15,18,23-24,36,46,48,55$, $60-63,68-70,72-73,75-77,94,98-112$,

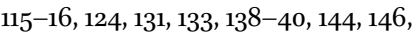
$15^{2-53}, 155,160,171-73,177-79,183$, 191-92, 196-97, 199, 213, 217-18

Christians $15,18,24,26,65,68-69,71,116$, 139, 143, 165, 171-72, 174, 177, 180, 197, 210

Chronicon (Polanco) $6 \mathrm{n} 14$

Church of England 50, 156. See also Anglicans

Church Missionary Society (CMS) 13-14, 46, $48-49,51,183$

churches $12,64,99,104-5,127,142,166,177$, 180, 190-92, 198, 212

Catholic churches $85,155,191$

Protestant churches $60,94,1015_{56,112}$, $115,151,153,155,157,162,179,204$

churchmen 48

Ciparisse, Gerard 203n21

CIs. See Center for Ignatian Spirituality

civilization $18,34,5$ on $45,51,52$ n 48,55 , $61-63,65,68,72,75,77,186,189,192$, 195-96, 199, 201, 208, 213, 220

civilizing missions $\quad 23,49-50,145,155,194$, $202 n 17$ 
Claretian fathers $216-17,219,224-26,228$, 229

Claretian mission $\quad 215$

Claretians $\quad 216-17,219,224-26,228,229$

Claudius/Gelawdewos 47

clergy $15,52,65-66,73,84,87,96,99,102$, 105

clergymen $\quad 66,90,145,187$

cleric 16, 219

clerical societies 15

climate $39,47,90$

Cline, Catherine Ann $\quad$ 196, 202n15, 204n23

Clinton, Iris $151 \mathrm{n} 1$

cloisters 41

Cluny, Joseph of, Saint $\quad 15,176,184$

coastal areas $35-36,44,174,176,192$

coexistence, of different missionary societies 121

Coillard, François $\quad$ 114, 155nı 8, 166

Colegio de Nobles de Madrid $\quad 222$

Coll, Emengol 215

collaboration $\quad 25-26,129,138-39,141$,

$144,147,155,164-66,184,188-89$, 199, 202, 208

collaborators $\quad 5,42,172,188$

colleagues 105,140

colleges 71, 90, 91, 116, 190, 203. See also specific colleges

Collins, Colin $\quad 95^{-96}$

colonial $3,15,17,21-22,38,41,71,73-74$, $77,86-87,91,93,115,119-21,125$, 133-35, 138-39, 141, 145-48, 157, 161-62, 171, 192, 194-96, 198-200, 203-4, 206-10, 212-14, 216-18, 220, $225^{-26}, 229$

administration $17,21,22,134,135,196$, 209

education $\quad 226-27$

government $115,119,121,125,161,162,225$

project $194,199,204,207,217,229$

colonialism $\quad 55,132,134,140,216-17$

colonialists 142

coloniality $\quad 136$

colonies $9,15,19,60,76,89,157,198,200$, 202, 205, 207, 216, 220, 226

colonists $\quad 12,86-87,89,93,142$

colonization $137,184,187,189,192,195,215$, 216

colonizer $\quad 136$
Colquhoun, Archibald $\quad 146$

combat $3,6,61,208$

Comboni missionaries 15

commerce $18-19,50,63,65,68,72,75^{-76}$, 199, 205

commodities 34,195

Communion 24, 126, 155, 173

communities $36,51,66,87,126,136,153,156$, $158,166,175,218$

Comoros, islands 60

companies, multinational $\quad 195,211,213,226$

competition $15,16,18,23,40,53,59-60$, 119-20, 124, 129, 151, 182, 194-95, 197, 199, 201, 203, 205, 207, 209, 211, 213

competitors 12, 162

Conceição, Manoel da 118

concession, Rudd 22, 141-42

concession, Lobengula's 22, 209

concessions, land and political 141, 202, 209

concordat, Congo Free state and Catholic Church 209

confession 124, 190, 211

confessional 100

conformity, African $\quad 124 \mathrm{n} 46$

confrontations $33,69,95,99$

Congo $17-18,25,64,73,169,194$

Congolese 195, 200, 205, 207, 209, 213, 217

Congregation de Propaganda Fide $13,19,25$, $116-17,129,198,203-4,218,220$

Congregation of Missionaries of Mariannhill (CMM) 9on21

Congregation of the Immaculate Heart of Mary 15

Congregation, Jesuit General $34^{\text {th }} \quad 163$

congregationalists $14,19,59$

congress

Chicago Congress 11

Pan-Anglican Congress 24

National Congress 99

conquest $\quad 12-13,15,23,35,73-74,77,187,189$

Conrad, Joseph $195 \mathrm{n} 1,200$

conscripts 98

Constitutions, Jesuit 4

consul $44,46,53,59,62,181-82,188$

consular 65

consulates $46,180-81$

convents 112,220

conversations, ecumenical $\quad 97 \mathrm{n} 43,97 \mathrm{n} 45$, $98 \mathrm{n} 46,99 n 52,100 n 55,106,183$ 
conversion $\quad 5^{-6}, 15,22,37-39,52,54,72,75$, $77,123-24,134,138,153-54,158,179,191$

converso 5

cooperation, of Catholics and Protestants

41, 49, 53, 84, 106, 120-21, 129, 139, 141,

$157,163,177,188,212$

Coptic Christians $\quad 35^{-37}$

Corisco, island 223

corn 86

coronation $36,178-79,181$

Correia, Frances $\quad$ 10on55, 102, 103n61

correspondence, missionary $74,122,140$, 171n2, 223

corruption $\quad 25,48,201$

cosmology $75^{-77}$

Cotain, Pierre $\quad 175^{\mathrm{n}} 21$

councilors 147

councils, ecclesiastical $\quad 36$

Counter-Reformation 4, 37, 217, 218. See also Protestant Reformation

Couto, António do $\quad 69 n 38$

Creary, Nicholas M. 21n43, 22n51

creation $25,103,115,117,179,203,218$

creed, differences in $17,26,226$

Creus, Jacint $\quad 215^{-16}$

crimes 101

crisis 101, 105, 139, 201, 225

Croonenbergh, Charles $\quad$ 158-61, 164, 204

Crowther, Samuel 219

crucifix 112,207

cruelties 146

Cuba 220

cults 179,188

culture $23,26,35,38,39,41,52,91-92,127$, 136, 196, 201, 213

Curia General, Jesuit $\quad 89$

currency 35

customs $21,23,24,35,39,41,127,136,139$, $158,159,174,196,201$

Da'amat kingdom 35

Dachs, Anthony

The Catholic Church and Zimbabwe

145n89, 147n101, 152n3, 16on38

Dalmond, Pierre $\quad$ 174-75

Daswa, Benedict, Saint 105

deacons 101

deaths $3,129,207$ debauchery 215

decapitation 38. See also beheadings

Declaration on Justification by Faith, Joint

Catholic-Lutheran $\quad 103$

Dejazmach Kassa 55

Dejima, island 33

Democratic Republic of Congo (DRC) 18. See also Congo

democratization 173

demons 217

demonstrations $\quad 97,215$

Dengali language 48

Dénieu, Romain $\quad 175 \mathrm{n} 21$

denominations $15,26,60,91,105,114,119-20$, $129,155^{-} 56,165,183,190$

Depelchin, Henri $\quad 20,117,137,152,156,164$

De Vos, Stanislas 211

devotional, items $\quad 12,105$

Diakonia 94

dialogue, Catholics and Protestants 5,38 , $94,100,104-6,129,150,163,166-67$

Dictamen general of November 3 , $1890 \quad 228-29$

dictatorship 140

differences, Catholics and Protestants 96, $125,150,164,206$

diocesan 89, 94, 104

diocese $15,23,117,130,142,146$

diplomacy $38,42,44,49,56,84-85,88,95$, $164,186,200,204,218$

disagreements 70,73

Discalced Carmelites $\quad 218$

discernment 13, 102, 203

disciples $5,7,181$

discoveries 40,76

discrimination 93, 209

diseases 129, 132

diversity $39,48,99,183$

divinity $\quad 96-97,159,173,230$

Djuma, South Africa $\quad 209$

docility 87,209

doctrines, differences in $7,20-22,26,126$, $153,155^{-}-56,187,222$

dogma 106

Dombodema, Zimbabwe $\quad 146$

Domínguez, Joaquín María 70

Dominicans $\quad 5,6,11-12,94-95,117-18,224$

donations $39,65,153-54$ 


\author{
Dondo, Angola 64 \\ Dougherty, Ed 101 \\ dowry 220n31 \\ DRC. See Democratic Republic of Congo \\ Driefontein, South Africa $\quad 165$ \\ drunkenness 154 \\ Dryden, David 98 \\ Dublin 8-9 \\ Duchesne, Jacques $\quad 189$ \\ Duffy, James $73 n 59$ \\ Dumont, Jean-Baptiste 200 \\ Dunn 196-97, 213 \\ Dunbrody mission $\quad 90-91,156$ \\ Dupont, Joseph/Moto Moto 118 \\ Durban, South Africa $\quad$ 90, 94 \\ Dutch Reformed Church 90, 94, 100, 105, \\ 123,125
}

East Africa $17 \mathrm{n} 30,50,51 \mathrm{n} 47,75,155$

EATwOT. See Ecumenical Association of Third World Theologians

economics $\quad 62-68$

Ecumenical Association of Third World Theologians (ЕАТWOT) 98

ecumenism 26, 6o, 83, 88, 91, 94-97, 100-1, $106-8,166$

Edinburgh, Scotland 48

Edmondstone, George $\quad 94,96$

education forum 65

education $19,47,63-65,90,96,114,115,116$, $122,124,137,156,161-63,173,181-84,196$, 200, 202, 205, 217, 223, 226-27, 229-30. See also women and adulteresses

of boys 25, 35, 89, 91, 156, 222, 227, 229

colonial 226-27

Protestant 182

Egerton, Frederick Clement Christie 73

Egypt $16,35-37,44,46,48-49,60,110,161$

Egyptian 34, 36, 53

EIC. See État Indépendant du Congo

eighteenth century $12,14-15,40-41,46,55$, 111-12, 116-17, 201, 217

Elandskop, South Africa $\quad$ 99, 101

elders 177,180

elections 100, 105

elites $35,71,132-33,135,137,139,141,143,145$, $147-48,184,202,227$

colonial $139,141,147,148$ cultural $\quad 35 \mathrm{n} 3$

local/native 202

political $135,139,141,145,147$

ruling 228

Elizabeth I (queen) 40, 89-90, 95, 116, 130

Elliot, William $\quad$ 145. See also LMS

Ellis, William $\quad 172 n_{5}, 175^{-77}$

embassies $37,38,49-50,54-55,84$. See also consulates

Empandeni, Zimbabwe $\quad$ 118, 123, 138-39, 143

emperors 47,53

employees 88,124

encyclical 200, 212

enemies $14,99,134,145,163,165,201,211,213$

engagement $22,43,47,51,55,88,97,100$,

105,107

England $6-7,40,45,50,90-92,114,153^{-54}$, 156,195

Englishmen $17,63,74,89,95,153,166$

Enlightenment $39,43,48,213$

enslavement, African 189, 198, 220. See also slavery and slaves

envoys 38, 181. See also ambassadors

Epiphany 102

episcopacy $\quad 156$

equality 154

equator 18, 136, 202

État Indépendant du Congo (EIC) 200. See also Congo Free State

Ethiopia $11-13,18,25,33-35,37-51,53$, $55^{-57}, 60,73,110,217$

Ethiopia above Egypt (Russell) 48

Ethiopian 16, 39, 40-42, 44-45, 47, 53, 55-57

Eucharist $96,118,178$

Europeans $35,38,56,84,90,132,135,142$, 159, 162, 188, 205, 220

Evangelical Fellowship of Zambia 128 evangelization 11-12, 14, 19, 22, 59-60, 70, $87,92,111-12,116,119-21,124-25,129$, $135,137,139-40,151,154-55,158-60,166$, 176-77, 184, 198, 204, 207, 215, 220, 226 See also London Missionary Society and Church Missionary Society

expeditions $33,53,54,63,110,114,204,216$, 218-219, 221, 229

expenses

Anglican mission in Mashonaland 146

Catholic mission in Fernando Poo 220 


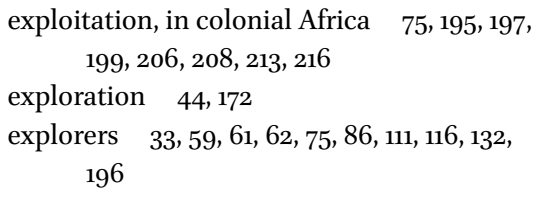

faith $4-5,13,22,54,59,62,68-72,75^{-77}, 88$, $93,110,125^{-26}, 134,13^{8-39,145,156-58, ~}$ $60,165,174,176,183,187-88,191-92,197$, $205,211-13,216,223,226$

families 124, 172, 184, 200, 210, 221, 225

famine 125

farmers 145

Farquhar, Robert $\quad 172$

Fasilides (negusa negast) $\quad 39-40$

fauna 84

Favre, Pierre 4

feminist 220

Fernandians, residents of Fernando Poo 216-17, 221-22, 225, 227-29

Fernando Poo, island $\quad 215^{-30}$

Fianarantsoa, region $\quad 1^{18}-86$

fiefdoms $\quad 35$

Fiesole, Italy 89

fifteenth century $\quad 12,36,110-111,197,198$ ng

Finaz, Marc $175^{-76}, 178,181$

firearms 133

Fitzsimons, James $\quad$ 10on55, 102-3, 104n63

Flacius Illyricus 7

Flemings 88,130

Flemish 8, 201

flora 84

foreigners $36,40,136-37,178,186,189,208$

forts and fortresses $5,86,87,144,211$

France Royal Academy $\quad 84-85$

Francis Albert Augustus Charles Emmanuel (duke) 60

Franciscans $\quad 6,11,165,224$

Franco, Francisco $\quad 215,217$

Franco-Hova conflict $\quad 184,188$

freedom

individual 213

religious $21,176-77,182,188,191,197-98$, 207,213

and trade $\quad{ }_{184 n} 6$

Freeman, Joseph John $\quad$ 174n18

Freetown, Sierra Leone 14

Fremona, Ethiopia $\quad 38-39$
French Revolution $\quad 15$

Frenchmen 17

Frenjy (L'Église des Amis) $\quad 183$

Frumentius $\quad 35,38$

Fullam, Lisa 224

funerals 99,188

Fwambo, Zambia $\quad$ 114, 125

Gabon 6o, 223-24

Gallieni, Joseph $\quad$ 190-91

Ganda, people $17 \mathrm{n} 30$

Gann, Lewis

A History of Southern Rhodesia 132n2, 135n21, 135n25, 137n35, 144n83

Garcías Cantús, Dolores 218n14, 226n68

garrisons $\quad 35,55$

Garth, Abraham 95n38

Gaughran, Anthony $153 n 8$

gay marriage 105

Gaza 26, 139

Gelawdewos (negusa negast) 47

Gelfand, Michael 19, 23

Genadental 14

General Missionary Conference (GMC) 120-22, 128-29

gender 224n 56,228

geographers $50,53-54$

geology 49

Germans $88,91,141$

Germany $7,8,196,222$

Geyl, Peter 85

gifts $20,85,133,135$

Gillet, Justin 200, 210

girls, education of $25,125,156,174,215$, 217-18, 221-25, 229

GMC. See General Missionary Conference

Goa, India $36-37,67,116$

Goanese 118

goats 210

Gobat, Samuel $\quad 46-49,52,55^{-57}$

gods $86 \mathrm{n} 12$

gold 35, 41, 66-67

Gonçalves da Câmara, Luís 5

Gondar kingdom 39-40, 42-43, 46

Gorgoryos (Father Gregory) 41

Gospel 13, 21, 23, 47-48, 60-61, 65, 77, 110, $112,116,119,132,136,140,147,151,156$, 158-6o, 179-80, 201, 206, 208 
governments $18,20-21,44,49-51,53,65$, $66,115,119-22,125,134,139-40,143-44$, 161-62, 172, 175, 177-84, 186, 189-92, 197, 202, 205, 208-10, 219, 225, 228-30

governors $64,69,73,85,172,176,182,187,215$, 226-30

Graaff-Reinet, parish $\quad 89-90$

Grahamstown, South Africa $\quad 89-91,95-96$, 137,151

grain 157

Greece $\quad 161$

Greenfell, George $\quad 207$

Griffith, Patrick Raymond 89

Griffiths, David $\quad 85,172,174$

Griqualand, South Africa 153n8

Griqua, people 87

Guatemala 203

Gubulawayo, Zimbabwe $\quad$ 19, 23, 26, 163-64

Guinea. See also Fernando Poo

Lower Guinea 73

Equatorial Guinea $\quad 215 \mathrm{n} 3$

Gujarat, India 103

Gwanda, district 144

Hakluyt, Richard $\quad 36-37,39-42,51-5^{8}$

Principal Navigations 40

Hanbury, Barnard 46

Harris, William Cornwallis $\quad 49-50$

Hartmann, Andrew 146

Hasenmüller, Elias $\quad 8-9$

Historia jesuitici ordinis $\quad 8-9$

Hastie, James 172

healthcare, colonial Congo 209. See also hospitals

heathenism 22, 24, 69, 160

Helm, Charles $\quad 22,141,164,197$

Hemptinne, Jean Félix de 211

Henry viı (king) 7

heresy $5,6,7,9,24,91,176,194,210-11,225$

heretics $5,8-9,24,33,120,126,206,211,217$

hermits 218

heroes 18, 21, 55

heroism 47n36

Hervier, Marc (Marc Finaz) 175

Heythrop College 102

highlands 34-40, 43-45, 49

Hinfelaar, Hugo $\quad 117-18,130$

hinterlands 89,132
Historia de la extinción y restablecimiento de la Compañía de Jesús (Zarandona) 222

História geral de Etiópia-a-alta (Lobo) 43

História geral de Etiópia-a-alta (Tellez) 40

Historia jesuitica (Wirth) 8-9

Historia jesuitica de iesuitarum (Hospinian)

$8 \mathrm{n} 21$

História jesuitici ordinis (Hasenmüller)

$8 \mathrm{n} 23,40$

Historiarum Indicarum (Maffei) $\quad 6 \mathrm{n} 16$

History of Rasselas (Johnson) 42

History of the London Missionary Society 1795-

1895 (Lovett) 172n3, 172n6, 173n11,

174n15, 177n3o, 179n38, 18on42-n43,

181n48, 184n53, 192

Hlobo, Rampe $98 \mathrm{n} 49$

Holy Ghost Fathers $\quad$ 15, 203

Holy Heart of Mary $\quad 15$

Home of Foreign Record of Foreign Missions (HFR) 230

Hospinian, Rudolf $\quad 8-9$

hospitality $\quad 86,136-37,163-64$

hospitals $25,116,127,142,190,209$

hostility $84,89,91,106,134,161$

Hottentots 86

Hübsch, Bruno 173n10, 175n23, 184n53

Hughes, Gerard W. 101

Huguenots 85

humanitarianism 140,141-42, 201

Huntingford, George Wynn Brereton 12n8, $36 n 4$

Hurley, Denis 94-95

huts 124, 210

hyenas 68

IAA. See International African Association

IAC. See International Association of the

$$
\text { Congo }
$$

identity 4, 56, 196, 213. See also Black Consciousness

ideology $4,9,36,166,206,173,218,220$

idols/idolatry $93,179,187,189$

Illa, people $\quad 114$

illnesses 69,203

imperialism $76,93,153-54$

inclusivity 180

inculturation $\quad 21,23,98,99$

incursions 132 
independence $46,85,127,184$

India $38,46,51,84,110,204,212$

Indians $\quad 36-38,40,51,63,72,118$

Indies 12,84

indigenous people $12,87,115,141,147,190$, 210, 220, 226-27

industrialization $132,162,212$

infrastructure 190

inhabitants 45, 156, 191, 207. See also Africans

injustice 159. See also atrocities

Inkatha faction 99

innovations 51, 104

Inquisition 4

insurrection $\quad 189$

interactions $33,36,45,88,150,159$, $165^{-66,212}$

intercourse, political and religious 34,37 , $39-40,75,164$

interdenominational $26,70,114,155,157-58$. See also ecumenism

interfaith 99. See also ecumenism

International African Association (IAA) 196

International Association of the Congo (IAC) 196-97

internationalism 35

interpreters $50,141,15^{2}$

interreligious 166. See also ecumenism

invasion $37,46,136,189$

inventions $195,198,210$

investments 116, 204

Inyati, village 19

Irísarri, José $\quad$ 222-23, 226, 228n79

irrigation 66. See also agriculture

Isenberg, Karl W. $\quad 47-50,53$

Islam 35,48

Istria 7

Italians $\quad 6-7,41,88$

Italy $36,89,161,224$

ivory $35,66-67,195$

Iyasu I (negusa negast) 42

Jameson, Leander $\quad$ 143, 146

Janissaries 71

Jansenists $\quad 222$

Jaricot, Pauline 116

jealousy, Jesuits and Protestants 14, 123, 182

Jehovah's Witness $\quad 128$

Jerusalem $\quad 4,48$
Jesuistry 24

Jesuit Institute South Africa (JISA) 104-6

Jesuitism 5

Jesuits $\quad 3-13,15-29,33-34,37-41,44-45$, $47-49,51-52,54-57,61-77,83-95$, 97-112, 115-30, 132, 135, 137-40, 146-52, 155-60, 162-67, 171, 173-79, 181-94, 199-200, 202-7, 209, 217, 219, 221-22, 229

accommodative efforts of $\quad 5^{2 n} 5^{2}$ anti-Jesuitism 8

anti-Protestant origin, myths of 8

battlefield collaboration with Protestants 144, 187

Belgian in Congo $17,117,158,194,202$, 203, 204, 206

Chartered Company and 147

Church Missionary Society (CMs) and 13

cooperation and collaboration with Protestants 84, 163, 188

De Vos, Stanislas and Moody, Thomas of 211

Dunbrody mission $\quad 90-91,156$

Dutch anti-Catholic laws in South Africa and $86-90$

economics of survival in Africa $\quad 62-68$

expulsion in Africa $50,63-64,67,225$, 227

failures in Africa $18,59,62,68,69,71,77$, $112,117,127,138-39,203$

farm-produce and silver mines in south central Africa and 63

French abstention from Madagascar 177 inculturation and Kaffirs of Africa 23 jealousy and Protestants 14, 123, 182 Khama III, chief and $\quad 20,133,137-39,152$, $152 \mathrm{n} 4$

legacy in Africa $\quad 46,55,59,68,75,135$

Leopold II and 194, 199, 200, 202, 203-7

Livingstone, David and $18 \mathrm{n} 34,19 \mathrm{n}_{3} 6$, $25,5^{0-51,53,59-60, ~ 62-79, ~ 112-13, ~ 151, ~}$ $155 \mathrm{n} 18,157,166,196$

Lobengula, chief and $\quad$ 138-39

Mangwato people and 20

Mbundu people and 74

Moemba, chief and 139

Monomotapa kingdom and 137

Mzilikazi, chief and 133

Ndebele people and $\quad 137-38,140$ 
Protestants' accusations against 16on39, 191

Salt, Henry's accusations against $\quad 45$

Spiritual Exercises and Protestants 102, 103

suppression and African missions 34,40 , $55,116,137,222$

Victorian geographer-scientists and 53

Zambezi/Zambesi mission of $18-20$, 22-24, 26-29, 67, 89-91, 117, 119, 150, $15^{2-53}, 156,160,203,205$

Jews $\quad 48,98$

jihad 37

JISA. See Jesuit Institute South Africa

jobs, technical skills and industrial training of Africans 162-63

Johannesburg, South Africa $\quad 91,95,97-98$, 100-2, 104, 107

Johns, David 174nı

Johnson, Samuel $\quad 12,42,44,51,189$

A History of Rasselas $\quad 42$

Jones, David $\quad 172-73$

Joseph of Cluny $\quad 15,176,184$

Jouen, Louis $\quad 175^{-78,180}$

Journal des missions evangéliques 190

Jouvancy, Joseph de 7, 9

Judd, Denis $\quad 75^{-76}$

Julius III (pope)

Defense of Faith 5

jurisdictions $\quad 15,18$

justice 106, 127, 159, 213

kabary 174

Kaffirs 23, 92

Kaffraria 23-24, 91-92

Kafue, plains $\quad 114,121,162$

Kafue Institute 129

Kagwa, Apolo, chief $\quad 17 \mathrm{n} 30$

Kairos Document 98

Kambole mission $\quad 125$

Kandale, territory $\quad 212 n 48$

Kasa, warlord $\quad 53 n 54$

Kasisi mission 119, 157

Kassa, Dejazmach 55

Kawimbe mission $\quad$ 125-26

Kayambi mission $\quad 118$

Kazungula mission $\quad 114$

Keilands mission $\quad 91$

kelimalaza $\quad 179$
Kenya 155

Kerr, Henry Schomberg 143

Kestell-Cornish, Robert $\quad 184$

Keteyi, Xolile $\quad$ 98-99

Khama III, chief $\quad$ 19-21, 133-34, 137-39, 152n4

Khoikhoi, people $\quad 60,86-87,151$

Khumalo, Mncumbata $\quad 133,136$

Kikongo, language $\quad 69 n 38,211$

Kikuyu, Kenya 155

Kikuyu conference $\quad 156$

Kimbau, Congo 211

Kimberley, South Africa $\quad 163$

Kimbundu, language $\quad 70 n_{3} 8$

Kimpa Vita 217

kings $12 n 436,166,197-98$

kingship 140

Kinnaird. See Bruce of Kinnaird, James

Kinshasa, Democratic Republic of Congo 211

Kisantu, Congo 210

Knight-Bruce, George W.H. 142

Knockaert, André $\quad 202 n 17$

Knox, Peter 10on5, 104

Kolbe House, Capetown 97

Kongo kingdom 11-12, 74, 76-77, 110, 217-18, 224

Kongolese $\quad 217-18$

kraals 124, 136

Krapf, Ludwig $\quad 48-51,53$

Kroonstad, Orange Free State province 94

Kruger, Frédéric-Hermann 190

kufr 92. See also Kaffir

Küng, Hans 103n61

Kuruman, South Africa $\quad 59,134,151$

Kwango mission 18, 200, 202-3, 211-12

KwaZulu Natal, South Africa $\quad 99 n_{53}$

Kwilu, Congo 202

laager 106

Laborde, Jean $\quad 176 \mathrm{n} 27,178,181-82$

Lagos, Nigeria $\quad 224,226$

Laínez, Diego 4

laity $67,99,105$

Lalibela, Ethiopia 35

Lambert, Joseph $\quad$ 16, 175-76

Lancashire, England $15^{2}$

Lane, William 110,118

Jesuits in Zambia 1880-1991 119n23, 119n25, 124n 45 
languages $\quad 23,41,50,60,70,90,141$. See also Bible

Laroche, Hippolyte 190

Lasta, Ethiopia 35

Lauga, Henri 190-91

Lavigerie Charles 11-12, 15, 201, 204

laws 21, 49, 87-88, 140, 174, 227-28

laymen 102, 114, 200, 221, 230

laywomen 102, 106, 221

Lazarist 11

Lealui, Rhodesia 113

Lebna Dengel 37

Le Brun, Protestant missionary leader $176 \mathrm{n} 27$

lehib 180

Leo XIII (pope)

Rerum novarum 200, 212

Leopold II (king) 194-208

Leopoldville 202

lepers 159, 188

leprosy 42

Lesotho $84 \mathrm{n} 2,89$

Levant $\quad 35^{-} 3^{6}$

Lewanika, people $\quad 21,113-14,117,119$

Lewis, Mike 104

Leyser, Polycarp II 8

Liagre, Edouard 200, 212

liberals 205

liberation movements $\quad 54,87 n 14,97,99 n 53$

Libermann, Francis 15

Limpopo river 117,142

linguists $43,54,118,211,217,219$

Linta, ethnic group $\quad 175$

lions 69

Lisieux, Thérèse of $\quad 218 n 15$

literacy $\quad 217$

literature $3,38,66,102,208,219$

liturgies $\quad 95^{-96}$

Liverpool, England 152

livestock 210

Livingstone, Charles $\quad 12 n_{5}, 64,67 n 27$

Livingstone, David 18n34, 19n36, 25, 50-51,

53, 59-6o, 62-79, 112-13, 151, 155n18, 157, 166, 196

Livingstone Inland Mission (LIM) 211

Livingstonia, Malawi 121

Llysfasi group 101

LMS. See London Missionary Society
Lobengula (chief) 21-22, 134, 136, 138-39, 141-42, 144, 161, 164

Lobo, Jerónimo $\quad 12,40-43,45,54$

Lofu River 114

Lombary, Edmond 200

London Missionary Society (LMS) 14, 20, $22,46,60,65,113-14,125,132,137-38$, $140-41,145^{-46}, 15^{1-52}, 164,171-75,177$, $179-84,186,188,190,192$

lords 34,40

Lorriman, Gerard 99

Lovett, Richard

The History of the London Missionary

Society 1795-1895 172n3, 172n6, 173n11, 174n15, 177n3o, 179n38, 18on42-n43, 181n48, 184n 53,192

Loyola, Ignatius of $3-10,12,37,103-4,135$, 221, 224, 230

Lozano, Manuel 225

Lozi, people $\quad 21,23,26,29,113-15,117,139$

Luanda, Angola 64

Luangwa River $\quad 67,117-18$

Lubwe, Zambia 114

Lucius, Ludwig 8

Ludolf, Hiob $\quad$ 41-42, 44, 48

Lugard, Frederick John Dealtry 17,76

Lusaka, Zambia 128

Luther, Martin $\quad 3-7,60$

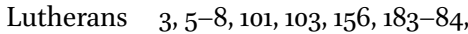
187-88, 222

Lutheranism 3,6

Luz. See Lucius, Ludwig

Mackay, Alexander $\quad 26$

Macqueen, James $50 n 45$

MacQueen, Ian 95n37

Madagascar $\quad$ 17-18, 70, 169, 171-92

Madrid, Spain $\quad 215^{-16,219,222, ~} 229$

Maffei, Giampietro $\quad 6,9$

Maguire, James 22

Magwero, Zambia $\quad 125$

maize 124

Majunga, Madagascar $\quad 189$

Makasa, chief 118

Makololo, people 71

Makoni district, Zimbabwe 144

Malabar $5^{1}$

Malagasy $\quad 172-77,180-85,189-91$ 
Malawi $\quad 76,89,114,151 n 3,152 n 3$

Mallorca, island 215

Malta Protestant College $\quad 13 n 14$

Malzac, Victorin $\quad 189$

Mambova, Zambia 159

Mambwe-Mwela 118, 126

Mandela, Nelson 99, 101

Mangwato, people $20,152,156$

Manica country 67

manjakatsiroa 179

Manresa, Spain $\quad 5,12,103$

Manuel I (king) 36

Mapanza, mission station $\quad 114$

Mariannhill monastery 90

Mariolatry 103

Marion, Iowa 15

Marist Brothers 104

Markham, Clements $\quad$ 53n54, 54n55

Markowitz, Marvin $\quad 17 n 31,198,199 n 11$, 211045

Marshall, Hartley 144

Marshall, Thomas William $\quad$ 16, 18, 22, 25-28, 134

Martínez Sanz, Miguel 219, 221, 229

martyrs $12,18,150$

martyrdom 174

Masanganu, Angola 64

Mashona, people 116

Mashonaland 141, 143-44, 146

masons 205

Massachusetts Indians $\quad 72$

Massawa, port of $\quad 36-38,44-45,52,54$

Matabele, people $19,133,138,142-45$, 158, 161. See also Ndebele

Matabele kingdom $\quad 133^{\mathrm{n}} 4$

Matabeleland 21, 132-133, 136, 138, 141-46, 149, 151, 159

Matomba, missionary $\quad 227 \mathrm{n} 4$

Matopos, Zimbabwe 144

Matsaneng, Puleng 10on55, 102, 104,

Matshobana/Matshobane, military leader 133n4, 134

Mauritius $\quad 60,172,174,176,189$

Mbundu, people 74

Mburuma, local ruler $\quad 117$

McGivern, Thomas $\quad 117$

medicine $52,116,129,136$

meditation 195

Mediterranean $\quad 35^{-36}$
Menalamba rebels $\quad 189$

menamaso $\quad 178$

Menas (emperor) 37

Mendes, Afonso 39, 54

Me'rawe (Meroë) 46

Mercurian, Everard 6

Merina kingdom $\quad 171,182-84,188,190,192$

Mesopotamia 38

metals 35

Methodists 14, 16, 89, 91, 95, 98, 100-2, $105,112,114,123,125,144,162,165$, 178, 217, 219, 225-26. See also Wesleyan Methodists

mfundisi 164

migrations 38

Mikael Sehul 43

militia 7

Mill Hill Fathers 15

minerals 66,141

miners 135

ministries $91,102,104,106,116,147,222$, 223-24

misogynistic 224

Missionaries of Africa 12, 15, 118, 126, 201. See also White Fathers

missionary explorer 155

missionization $37,5^{2}$

missions 11-16, 21, 23, 25, 50, 59-61, 63, 67-68, 87, 89-92, 113, 115-16, 121-22, $124-25,146,171,178,180-82,190,192$, 197-98, 203-4, 209-10, 216-17, 219, 222, 227

Mkuze, Zululand 133

Mncumbata Khumalo 133

Modernism 218

modernity 195, 210, 218

Moemba, chief 139. See also Tonga

Moffat, Robert $\quad 19,59-61,70-71,132,134$ $140-41,151,155,158,166$

Mohammedanism 155

Moir, Fred L.M. $\quad 76 \mathrm{n} 68$

monarch $140,171,173,183$

monarchy 173

monasteries 6, 65, 90

Mondain, Gustave $179 n 39$

Mondy, Thomas 211

monks 40-41, 65-66, 90

monogamy 124, 126

Monomotapa (king) $\quad 11,137,150$ 
monopolies $36,41,178$

monopoly 14, 38, 205, 209, 216, 228-29

Montes de Oca, José 226

Montserrat mountains 6

Monze, Zambia $\quad$ 114, 117-18, 123, 127, 130

Moore, Basil $\quad 95^{-96}$

Moravian 14, 113, 151

Moreau, Joseph 19n37, 20n41, 21n44, 22n51, $118,123-25,127,129-30,165$

Moreau, Edouard de 210

Morgan Thomas, Thomas 151

Morrison, James 21

Moto-Moto 118

Mozambique $11-12,18,65-68,70,73,89,97$, $111,116,137,157$

Mponda-Mambwe $126 \mathrm{n} 49$

Mpumalanga, South Africa $\quad 165$

Msoro, Zambia 114

Mthwakazi 133n4. See also Matabeleland

Mtshali, Benedict

Rhodesia: Background to Conflict 133n6, 134n17, 135n20, 139n53, 141n64

Mudimbe, Victor Yves $195 \mathrm{n} 2,196 \mathrm{n} 6,198 \mathrm{n} 8$, 198n10, 202n15, 210

Muhammad Ali Pasha $\quad 46,49,5^{1}$

multi-denominational 14. See also ecumenism

Murrey, Antonio 222

Muslims 40, 151, 198

Mwanza, Tanzania 211

Mweemba, chief $\quad 117$

Mwela. See Mambe-Mwela

Mwene Mutapa 111, 116. See also Shona

Mwenzo mission 114

mythologies $\quad 34^{-35}$

Mzilikazi, chief $\quad 133,136$. See also Matabeleland

Nadal, Jerónimo $\quad 5^{-7}$

Nagasaki, Japan 33

Nalolo, mission station $\quad 114$

Napier, Robert 55

Nassau, Bella 227

Natal, south Africa $\quad$ 19, 6o, 89-90, 99

National Catholic Federation of Students (NCFS) 94, 96

National Union of South African Students (NUSAS) 95

nationalism 55 natives $24,52,62,64,68-69,72,77,139$, $142-43,153-54,156-57,159,161-63$, $166,173,175,195-96,199,202,205$, 207-9, 225

naturalism 155

Naudé, Beyers 94

NCFS. See National Catholic Federation of Students

Ndebele, people $\quad 21-23,132-38,140-47$, 158-59, 164. See also Tabili

Ndjuke, feminist in Fernando Poo 216, 229-30

Ndlovu-Gatsheni, Sabelo $\quad$ 133n5, 134nı1, 134n16, 134n18, , 136n27, 136n29, 136n32, 137n24, 138n39, 138n43, 139n50, 139n52, 141n62, 141n65, 141n68

negroes 15,71

negus 49

negusa negast $\quad 36,38-40,43,53-56$

Neill, Stephen $\quad 20-21,70$

Netherlands 90

Neyraguet, Ambroise $\quad 175^{\mathrm{n} 21}$

Ng'Ekieb, Fernand Mukoso

Les origines et les débuts de la mission du

Kwango (1879-1914) 202n18, 203n2o, 204n24, 205n26

Ngwabi, Bhebe 133n10, 138

Niamikolo, mission station $\quad 114,125$

Nichols, Jill 215

Niger expedition, First $\quad 219$

Nigerian 215

niggardliness 66

Nile River $\quad 34,43,45^{-46}$

Nkala mission $\quad 114$

nobility 218

Noble, Perry $\quad 11,14 \mathrm{n} 17,15,16,17,18$, 19, 2on39, 21, 22n19, 24, 25n65, 26, 140n55

noble $68,71,116$

nobleman 44

Nosy Be 175

novice 90,97

novitiate 90,119

Nubia $37,46,49$

nuns 218, 221

nurseries 209

NUSAS. See National Union of South African Students

Nyasa, lake $\quad 151$

Nyasaland $\quad 162$ 
Oblates of Mary Immaculate (OMI) 89

O’Brien, Mary 117

Oceania 160, 174

oligarchs 178

oligarchy 173

Opium 62

Orlandini, Niccolò 6

ornithology $5^{2}$

Oromo, people $38,40,48 \mathrm{n} 38,53$

Orthodoxy $\quad 11-12,14,16,35,46$

Ottomans $36-38,46,71$

Oviedo, Andrés de $\quad 37-38,47,49$

owl 68

oxen 112

\section{padroado 12}

Páez, Pedro $38-40,43,45,47,49$, 52, 54

História geral de Etiópia-a-alta 40

paganism 219

pagans 38,198

Palestine 49

Palmerston, Lord prime minister (Henry John Temple) $\quad 5^{1-52}$

Pandamatenga, Botswana $\quad 117,158$

papacy 15,38

papal bulls $\quad 5,197,198 \mathrm{n} 9$

Paraguay 25

Paraguayan 210

Parana 21

parishes $\quad 90,96-99,101-2,104,127-28,155$, 192, 219

Paris Missionary Society (PMS) 114, 115, 125

Parkyns, Mansfield $\quad 5^{1-52}$

pastors 99, 172, 174, 179, 182-83, 187, 190

Paul IV (pope) 8

pax Britannica 17

Pennec, Hervé $\quad 38 n 9,39 n 10$

Pentecostals $\quad 98,101,104-5$

pestilence 68

petrol 100

philanthropy 206

Philippines 229

philosophy 90, 95

Phoenicians 40

Pickersgill, Clayton $\quad 188$

pioneers $19,47,49,55,60,63,146,181$, 200, 229

Pius VII (pope) 116, 135

Plumer, Herbert 144
Plymouth, England 113

PMMS. See Primitive Methodists Missionary Society

PMS. See Paris Missionary Society

Polanco, Juan Alfonso de $\quad 5^{-7}$

policies 111, 119, 121, 195, 199, 229-30

Pollitt, Russell 100n55, 105

Polycarp Leyser II 8

Imago primi saeculi $\quad$ 9, 9n24

polygamy $23-24,126,156,158,220-21,229$

Pombal, Marquis of $\quad 64,222$

Poncet, Charles-Jacques 42

Poo, Fernando $\quad 169,215,218,220-21,223$,

$$
225^{-26}, 227,230
$$

pope $6,7,12,37,137,198,201,211$. See also specific popes

population $4,47,71,119,124-25,127-29,162$, $164,184-85,196,207-8,211-13,225$

ports $36,39-40,44,73$

Portugal $12,14,36-37,40,67,73,77-78$, 110, $196-98,204,218$

Portuguese $11-12,36-38,40-42,45,47$,

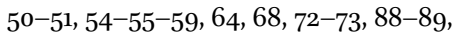
110-11, 116-17, 150, 197, 204, 217

poverty 160

prayer $102,132,140,181,185$

prayer books 69

preachers 92

prefect $152,174-75,180-81,185,211$, 215,229

prejudices $153-154,156,164-65,187$, 194-213

Presbyterians 14-15, 26, 114, 125, 151

Prestage, Peter $\quad 118,138-39,142-44,146,155$

Prester John 11, 34, 36, 41

Pretoria, South Africa 104

priesthood $46,64,96,126$

priests $16-17,22,33,43,45,52,54,85,89$, 93-94, 96, 102, 110-11, 116, 118, 124, 126, $165,175,181,183,186-87,189,195,200-2$, 203, 222, 205, 209, 221

Primitive Methodists Missionary Society (PMMS) 114

prohibition $\quad 88,89$

Propaganda Fide $13,19,25,116-17,129,198$, 203-4, 218, 220

proselytism 173, 227

proselytization $\quad 4,209$

Protestant Reformation 3 
Protestantism $\quad 3-7,9,12-13,16,24,70,92$, $154-55,157,177-78,181,183,192,202$, 209-11, 213

Protestants $3-4,8-11,33-34,55,57,60,66$, 71, 83-85, 87-89, 91-95, 97, 99-107, 112, 119-20, 122, 124-30, 132-133, 135, 137, 139-41, 143, 145, 147-58, 160-61, 163-66, 171, 173-79, 181-83, 185-94, 197-203, 206-9, 211, 219, 222, 225-26, 230 battlefield collaboration with Jesuits 144, 187

expulsion in Fernando Poo 226 legacy in Africa $18,55,74-76,101 n_{5} 6$ missionary failures in Africa $75,112,115$, $127,129,134-35,138,157$

Pugin, Graham 98, 100, 102

Puleng Matsaneng 100, 102, 104

punishments 217,220

pupils $177,187,216$

purgatory 126

Quakers $183,187,189$

Quebec, Canada $\quad 224 n 56$

Rabodo (queen) 178. See also Rasoherina racism 92, 95

Radama I (king) 171n1, 172, 173

Radama II 176, 178, 192

Rahidy, Basile $\quad 175,183$

Rahner, Karl 103

Rainilaiarivony $179,181,192$

Rainimaharavo $\quad 180-81$

Rainitsimbazafy 186

Raison-Jourde, Françoise $\quad$ 179n40, 184

Rajoelison, Haja 184

Rakoto, prince 176. See also Radama II Ramoma/Ranavalona II (queen) $\quad 178$

Ranavalona II (queen) 171nı, 178, 180, 182,192

Ranavalona III $\quad 184,190$

Randrava, Antoine $\quad 181$

ras 40, 43-44

Rasalama 174

Rasoamanarivo, Victoire $\quad 181,185,188$

Rasoherina (queen) 171, 178, 180

Ravenstein, Ernst Georg 53

rebellions $\quad 35,41,54,142,189$

rebels $54,144,181,189$

Red Rubber scandal 207
Red Sea 34, 35, 36, 38, 39, 44, 45. See also Massawa

reform 196, 202, 204, 213, 216

Reformation $3-4,6,9-10,12,37,70,93,106$, 120, 126, 217-18

Reformed Church $87,123,125$

regime $97,189,191,208,215$

relics $68,70-71,72,77$

Remacle, Charles 175 n21

Renaissance $34,36-37,224$

Répression de la révolte des Pende du Kwango en 1931, La (Vanderstraeten) 212n48

republics 89

Rerum novarum (Leo XIII) 200, 212

resources $25,43,49,56,65,68,129,132,162$, 195, 205-6, 225

Ressource, La 175,177

Réunion, La $\quad 60,175^{-76}, 189$

revolution 49, 225. See also rebellions

Rhodes Catholic Society 96

Rhodes, Cecil John ２2, 76, 89-90, 93, 113, 119, 135, 141-43, 145-46

Rhodes, Frank W. 147

Rhodesia 22, 91, 97, 113-15, 121-23, 128, 131-36, 139-41, 144, 147-48, 154, 158, 162. See also Zimbabwe

Rhodesiana 152, 159

Rhodes University $95^{-96}$

Ribadeneyra, Pedro de $\quad 5^{-7}, 10$

Richardson, J., pastor at Ambahivoraka 188

Richartz, Francis $144 n 78,145 n 87,157 n 26$, 159,16 on $_{3} 6$

rites $37,48,127$

rituals $26,159-60$

rivalries $51,120,122,129,195$

rivers $39,67-68,132$

Robben Island prison 99. See also Lorriman, Gerard

Rodrigues, Simão 4

Roebuck, Oliver 123. See also Methodists

Roehampton, England $15^{2}$

Roger, Onomo Etaba 218

Rome $6,12-14,16-17,19,24,36,40-41,48$, $61,67,71,77,104,106,120,122,126,177$, 203, 212, 218

Rosary, Our Lady of the 117

Rotberg, Robert $115,122-23$

rubber 97,195

Rudd concession $\quad 22,141-42$ 
Rusangu, Zambia 114. See also Seventh-day Adventists

Russell, Michael $\quad 37,48-49,51-52,100,105$ Ethiopia above Egypt 48

SACBC. See Southern African Catholic Bishops' Conference

sAcc. See South African Council of Churches sacraments $22,88,126,165$

Sadeleer, Frans de 200

Safavids 38

Sahara 11, 110-11

Sahle Selassie (negus) 49. See also Shoa

Saint Moulin, Léon de $\quad$ 200, 203, 207, 210-11

Sakalava, tribe 183

Salisbury, England $\quad 22$, 90-91, 144, 147

Salt, Henry $\quad 44-46,49,56$ A Voyage to Abyssinia $\quad 44 \mathrm{n} 23$

salvation $93,111,126,136$

sAso. See South African Students' Organization

scandals $26,207,216$

Schapera, Isaac

David Livingstone: Family Letters 1841-1856 19n35, 63n12, 64n17, 7on 45, 72n48-n49

Scheut Fathers 15, 201, 205

Schmidt, Georg 151

Schomberg Kerr, Henry 143

Schön, James F. 219, 230

schooling 161,182

schoolmistress $216,226,229-30$

schools $25,52,65,89,91,104,114,116,123$, $125,127-28,142,158,161-62,172,177$, 182-84, 186, 190, 209, 226-29

sciences $5^{1}$

Scientific Revolution 49

scientist $49-50,51,53-54,62,65,84,86,115$, 197-98, 200

Scottish $\quad 15,59,62,75,211$

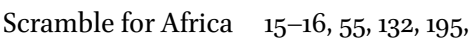
201, 206

scriptures $23,46,69-71,126$

sDA. See Seventh-day Adventists

Sebaste, kingdom of 73

Sechele I, chief $\quad 75,77$

Second Great Awakening $\quad 47 \mathrm{n} 33$

sects $22,25,92,123,154-55,157$

secular $7,50-51,53,55-56,61-62,68,95$, 105-6, 219, 230
Sefula, mission station $\quad 114$

Sehul, Mikael 43

Sekgoma I, chief 137

Selassie, Wolde 44

Selassie, Sahle 49

seminarians 105

seminaries $\quad 97,101,104,107,172$

Senafe, Eritrea 55

Serenje, Zambia 113

serpents 68

servants $76,156,163,187$

servitude 201

Sesheke, mission station $\quad 114$

settlements $66,86,110,114,138,158,202$

settlers 163,219

Seventh-day Adventists (SDA) 114, 123, 125, 127-29

Sexwale, Tokyo 99

Shaka (king) $\quad$ 133n 4

Shaw, Mark 43, 111

Shimmin, Isaac $\quad 144-46$

shipwrecks 35,38

Shoa, kingdom $\quad 48-49$

shoemaking 156

Shona, people $11,23,111,132,134-35,141-42$, $145^{-47}$

Shoshong, mission $\quad 19,15^{2}$

Siam $\quad 12,84$

Siameja, village 117

Sibree, James 174nı6, 179n39

Sichuana, language $\quad 166$

Sierra Leone 14, 218, 224

Siervas de María 221037

Silveira, Gonçalo da $\quad 11-12,111,116,150$

Simmons, Jack 75

Sims, Aaron 211

Sisters of Divine Love $\quad 220$

Sisters of Our Lady of Africa 15

Sisters of St. Joseph $\quad 15,176,184$

Sisters of the Holy Ghost 223

Sisters of the Immaculate Conception $\quad 219$, 226

Sjöholm, Edvard Vilhelm 207. See also Leopold II

Slade, Ruth Reardon $\quad$ 197, 201-3, 208-9

slavery $59,62,72-75,86,200112,201,205$, 220

slaves $5,35,73-74,88,151,202,216,220-21$, 228 
slave trade $18,26,59,72-76,197,200 n 12$, 201, 202

Smith, Charles 212

Smith, Drew R. $\quad 115$

Smith, Maria $\quad 215,226-28$

Smith, Robert $\quad$ 202n17, 206n3o, 208n35, 209, 211n45, 212n49

Smith, Samuel $41 n 16$

Smith, Tim 99, 100n54

Smolira, David 100n55, 104-5

Société des Missions Evangéliques de Paris 190

Society of Jesus. See Jesuits

Society for the Propagation of Faith $\quad 116$

Solages, Gabriel Henri Jérôme de 174

soldiers $\quad 6-7,144,189,195-96,199,202$

Solomonic dynasty 38,40

Solusi, Zimbabwe 146

sorcery 23

Sotho evangelists 114

South African Students' Organization (SASo) 95

Southern African Catholic Bishops' Conference (SACBC) 94-95, 104-7

South African Council of Churches (SACC) 94, 98,101

sovereigns $35^{-}-37,43-44,55,210$

sovereignty $135^{-136,184,188,197}$

Soweto, South Africa 98, 102

Spain 4, 16, 196, 198, 215-18, 225-26, 229

Spaniards 88

Spendel, John $\quad 165$

Spiritains 223-24

Spiritual Exercises $\quad$ 5, 102, 103, 210, 224

spirituality $66,97,101-6$

St. Aidan's College, Grahamstown 90-91, 93, 95-96, $15^{1}$

St. Augustine's College, Johannesburg 104

St. Beuno's, Wales 102

Stanley, Henry Edward John $\quad 37 n 6,51 n 47$

Stanley, Henry Morton 196, 206

Stenström, Gösta $\quad 206$

stonemasonry 162

students $\quad 95,97-98,101-2,172,182,184$, 189-90

Suau, Pierre $\quad 186-87$

Sudan 15,60

Sudanese 14,60 ,

superstitions $47,68,138,154,158,161$ suppression, Jesuit $\quad 34,40,55,116,137,222$

Susenyos I (negusa negast) 39, 54

Swaziland 84,89

Swedish 206-7

Swiss 8,46

Sykes, Robert $\quad 24-25,93,152-57,161-62$

Syria 161

TabaZiKa-Mambo 144

Tabili 21. See also Ndebele

Tabora, Tanzania 113

Tachard, Guy $\quad$ 12, 84-88

Tamatave, Madagascar $\quad 185,189$. See also Toamasina

Tana, lake 39

Tanganyika, lake $\quad 76$

Tanzania 113

Tanzanian 114

Tati $15^{2 n} 4$

teachers $61,64,69,98,135,152,154,162,164$, $172,182,190,227$

Tellez, Balthazar $\quad 40-42,45$

Temple, Henry John $\quad 5^{2}$

Tenysoa 183

territory $12,15,18-20,21-22,50-51,64,85$, 88-90, 113, 115, 117, 119-21, 133, 137-38, $144,146,151-52,156,179,182,184$, 195-96, 198-200, 204

Tewodros II (negusa negast) $53-54,56$

Theatines 8

Theologiae jesuitarum praecipua capita 8

theologians $8,95,97,103,224$

theology $8,18,90,95^{-96}, 100,102-3$, 125-26

Thibaut, Emile $\quad 25 n 68$

Thomson, John Boden $\quad 151$

Thornton, John K 12n7, 13n10, 23n55, 73, 74n61, 76-77, 217n12

Tigray, Ethiopia $\quad 35,44,47-48,52,55$

timber 63

Toamasina, Madagascar 174, 176

Toka-Leya, people 113

Toledo, Spain 223, 230

Tonga, people $23,26-27,29,113-14,117-18$, $123,139,162$

Tongaland 26

Torrend, Julius 118,129

tortures 174,229

townships $99,104,145$ 
traders $21,36,65-68,110,116,132,151,175$, 201-2, 205

traditions $23,35,38,54,56,90,106,112,127$, $136,160,218,223$

transmigration $\quad 69,87$

transubstantiation $\quad 126$

Transvaal 89

Trappist monks $\quad 90,156$

travelers $34,36,43,46,51,5^{2}, 166$

TRC. See Truth and Reconciliation Commission

treaties $172,178,181-82,185-86,188-89,196$

tribes $50,61,66,118,157,183,201$

tributes 20, 39, 112

Triumphus papalis $8 \mathrm{n} 23$

troops $3,135,144$

Truth and Reconciliation Commission (TRC) 101

Tswana, people $\quad 60,70-71$

Tutu, Desmond 101

tyranny 143

tyrants $\quad 21,224$

UCM. See University Christian Movement

Uganda 16-17, 26, 155

Ujiji, Tanzania 113

Ukambala, Manuel, chief $\quad 216$

Ullendorff, Edward 41n15, 44n21

universities 48,107

Universities Mission to Central Africa 14, $18 \mathrm{n} 34,62 \mathrm{n} 8$

University Christian Movement (UCM)

$$
\text { 94-96 }
$$

Unyanyembe, Tanzania $\quad 166$

Ursulines Sisters $\quad$ 224n56, 224n 58

Uruguay 21

Usera y Alarcón, Jerónimo Mariano 219-21

Vakinankaratra, Madagascar 183

Valencia, Spain 221

Valignano, Alessandro $49 n 40$

van der Kemp, Theodorus 60

van der Stel, Simon 85

van Eetvelde, Edmond $\quad$ 202, 205

van Hee, Sylvain 212

van Hencxthoven, Emiel $\quad 200,203,207$, 209-10

van Houtte, Auguste 200

van Reeth, Joseph 203 van Rheede, Hendrik Adriaan 85

van Velsen, Gerard 94-95

Vanderkemp, Theodorus 60

Vanga, hospital 209

Vatican $68,93-96,100,105-6,126,166,198$, 200-1, 203

vato masina 173

Vaughan, Herbert Cardinal 17

vegetables 66, 124. See also agriculture and maize

Venetian 36

Vianney, John, Saint 104

vicariate $15,18,85 \mathrm{n} 6,89,185$

Victoria Falls 113, 117

Victoria (queen) $51,53-54 \mathrm{n} 57,176 \mathrm{n} 27$

Victorians $\quad 55^{-} 5^{6}$

Vilers, Charles Le Myre de $\quad 186$

villages $25,124-25,160,179,181,206-10$

Villèle, Joseph de 189

violence $134,182,190,195,200,204,208,227$

Vita, Kimpa 217

vocation $5,101,161,224$

von Bora, Katharina 6

Voyage to Abbyssinia (Salt) 44

Vuselela 100, 102, 104. See also Center for Ignatian Spirituality

Waddington, George $\quad 46$

Wales 102

Wallis, John Peter Richard

Zambezi Expedition $\quad 59 \mathrm{n} 1,63 \mathrm{n} 10,65 \mathrm{n} 20$, 72n5o, $76 \mathrm{n}_{71}$

Walmesley, Herman $91 n 23$

Walmsley, Gerard 104

Walshe, Peter $94 n 34$

Wansleben, Johann Michael $\quad 41014$

warfare $7,72,145$

warlords $37,39,53$

warmongers 140

warriors 137

wealth $\quad 25,36$

weapons 55

Webber, Joseph $\quad 175^{-76}$

Weisskopf, John $\quad 158$

Weld, Alfred $\quad 21,89,151-52,156-58,163,166$

welfare $45,65,96$

Wesleyan Methodists 23, , 91, 92, 114, 144, $146,151,165$

West Africa $\quad 14,72-73,124$ 
White Fathers $15,118,165,201,203$. See also Missionaries of Africa

wildlife 39

Williams, Basil $\quad 76 n 69$

Williams, Joseph Watkin 23

Williams, Norman Powell 87,156

Wilson, John 25n66

Wirth, Rudolf 8

witchcraft $\quad 23,116,36,138-39,158,219$

Wits campus 97

Wittenberg, Germany 4, 120. See also Rome and Vatican

Witwatersrand, University of $96 \mathrm{n} 40,96 \mathrm{n} 42$, 97, 101-2

Wolde Selassie 44

women $15,215,217-20,223-24,230$. See also adulteresses

emancipation of $\quad 215,229$

workers 202, 212

worship $47,68,118,140$

Xaba, Jeff 98

Xavier, Francis, Saint $\quad 115^{-16}, 15^{2}, 212$

Xhosa, people 60

Xolile Koteyi $\quad$ 98-99

Yeha, Tigray province 35

Yemen 38

Yohannes IV (negusa negast) 55

Yonah Seleti $63 n 13$

Za Dengel (negusa negast) $\quad 38,47$

Zagwe dynasty $\quad 35,3^{8}$

Zamana Masafent 40
Zambesi Mission Record 91, 92, 93n30-n32, 120n27, 144n78, 152-53

Zambesi River 67

Zambesia 19,

Zambezi Expedition (Wallis) 59n1, 63n10, 65n2o, 72n $50,76 \mathrm{n}_{71}$

Zambezi/Zambesi mission 18-20, 22-24, 26-29, 67, 89-91, 117, 119, 150, 152-53, $156,160,203,205$

Zambezia 73,144

Zambia 19, 21-22, 84, 89, 110, 12-30, 150, 152, $157-58,162,165$

Zambian 1, 112-13, 115, 126

Zanzibar $75,155,188$

Zara Yaqob 36

Zaragoza, Spain $\quad$ 215, 229

Zarandona, Antonio $\quad 217 \mathrm{n} 13,222,225$, $227 \mathrm{n} 76$

Historia de la extinción y restablecimiento de la Compañía de Jesús 222

Zeila, Somalia $37,48,54$

Zimbabwe 11, 21, , 84, 89-90, 97, 111, 116-18, $123-24,133,136,138-39,141-42,144-52$, 157, 160, 163

ZMr. See Zambesi Mission Record

zoology 49, $5^{2}$

Zulu 90, 100, 133, 137. See also Shaka

Zululand 133

Zumbo, Mozambique 67,118

Zvobgo, Chengetai J.M.

Christian Missions in Zimbabwe 138n40, 138n47, 139n51, 141n66, 142n71, 142n72, 144n81, 144n84, $145 \mathrm{n} 88,145$ ngo 